\begin{abstract}
UNIVERSIDADE DE SÃO PAULO
FACULDADE DE FILOSOFIA E CIÊNCIAS SOCIAIS

PROGRAMA DE PÓS-GRADUAÇÃO EM ANTROPOLOGIA SOCIAL
\end{abstract}

JULIANA MONTEIRO GONDIM

Seguindo trilhas encantadas: humanos, encantados e as formas de habitar a Almofala dos Tremembé

São Paulo

2016 


\author{
UNIVERSIDADE DE SÃO PAULO \\ FACULDADE DE FILOSOFIA, LETRAS E CIÊNCIAS HUMANAS \\ DEPARTAMENTO DE ANTROPOLOGIA \\ PROGRAMA DE PÓS-GRADUAÇÃO EM ANTROPOLOGIA SOCIAL
}

\title{
Seguindo trilhas encantadas: humanos, encantados e as formas de habitar a Almofala dos Tremembé
}

Tese de Doutorado apresentada ao Programa de Pós-Graducação em Antropologia Social do Departamento de Antropologia da Faculdade de Filosofia, Letras e Ciências Humanas da Universidade de São Paulo, para a obtenção do título de Doutora em Antropologia Social

Orientadora: Profa Dra Dominique Tilkin Gallois 


\section{RESUMO}

Abordarei nesta tese algumas das relações estabelecidas entre os Tremembé de Almofala e os encantados. Os primeiros são um grupo indígena que vive às margens do Oceano Atlântico, no litoral oeste do Estado do Ceará, Nordeste do Brasil, e os encantados são entidades presente nas cosmologias de vários grupos - indígenas e não indígenas - na América do Sul. Os encantados são apresentados de formas muito variadas. Uns os descrevem como pessoas que - antes ou após a morte - passaram para uma forma de existência onde não são afetados pela passagem do tempo e são invisíveis para a maioria das pessoas; outros os apresentam como sendo personagens do panteão umbandista, fadas, príncipes e princesas... e há, ainda, os que os colocam como entidades que habitam e protegem as matas, como Caipora, Mãe d'Água ou Guajara. Eles podem se manifestar sob a forma que quiserem, às vezes humanos, às vezes animais ou, mesmo, seres antropomorfos. Essa diversidade de versões sobre os encantes me colocou diante de vários mundos constituídos por uma multiplicidade de agências e subjetividades distintas. Algo em comum dentre tanta diversidade é o fato de que todos se referem a áreas como mangues, lagoas, mares, matas e dunas como sendo moradas de encantados. Por isso, quando abordam o avanço da degradação ambiental na Área Indígena, os Tremembé demonstram uma grave preocupação com o destino dos encantados que estão, assim como os humanos, vendo suas moradas sucumbindo às investidas do agronegócio. Procurei lançar reflexões sobre como são esses encantes, como se manifestam, com que propósito agem nesse mundo, quais suas atribuições. Ressalto que os tratei como estando numa posição simétrica em relação aos humanos, posto que, assim como nós, eles também agem e transformam os mundos em que vivem. Nesse sentido, a proposta metodológica da Teoria Ator Rede - que defende a ideia de que os não humanos devem ser tratados como atores e não meras projeções simbólicas da humanidade - me possibilitou seguir as redes de relações formadas a partir da categoria "encantados" e, assim, colocar no mesmo plano de análise elementos diversos, como encantados, humanos, rituais, paisagens e os empreendimentos relacionados a diferentes ramos, como o turismo, o agronegócio e a pesca predatória.

Palavras-chave: Dinâmicas territoriais. Encantados. Tremembé de Almofala. Cosmologias ameríndias 


\begin{abstract}
In this thesis I will discuss some of the relationships established between the Tremembe of Almofala and the encantados (enchanted). The former are an indigenous group that lives on the shores of the Atlantic Ocean, on the west coast of Ceará State, northeast Brazil, and encantados are entities present in the cosmologies of various groups indigenous and non-indigenous - in South America. Encantados are presented in very different ways. Some describe them as people - before or after death - passed to a form of existence not affected by the passage of time and they are invisible to most people; others present them as characters of umbanda, fairies, princes and princesses ... and there are also those who put them as entities that inhabit and protect the forests, as Caipora, Mãe d'Água or Guajara. They can manifest themselves in the form they want, sometimes human, sometimes animal or even anthropomorphic beings. This diversity of versions of Encantados put me in front of several worlds constituted by a multiplicity of agencies and different subjectivities. Something in common among such diversity is the fact that all relate to areas such as wetlands, lakes, seas, forests and dunes, as houses of encantados. Therefore, when addressing the advancement of environmental degradation in the indigenous area, the Tremembé demonstrate a serious concern for the destiny of encantados who are, just like humans, seeing their houses succumbing to the spread of agribusiness. I tried to launch reflections on how are these encantes, how they manifest, for what purpose they act in this world, what their assignments. I emphasize that I treated as being in a symmetrical position in relation to humans, since, like us, they also act and transform the worlds in which they live. In this sense, the methodological proposal Network Actor Theory - which supports the idea that not-humans should be treated as actors and not mere symbolic projections of humanity - enabled me to follow the networks of relationships formed from the category "encantado" and thus put on the same plane of analysis different elements, such as enchanted humans rituals, landscapes and developments related to different fields such as tourism, agribusiness and overfishing.
\end{abstract}

Keywords: Territorial dynamics. Encantados. Tremembé de Almofala. Amerindian cosmologies. 
Dedico esta tese a duas pessoas muito queridas que tanto me ajudaram nessa jornada, mas que se encantaram antes de vê-la concluída: Dona Maria Bela e Dona Inácia 


\section{SUMÁRIO}

Agradecimentos $\ldots \ldots \ldots \ldots \ldots \ldots \ldots \ldots \ldots \ldots \ldots \ldots \ldots \ldots \ldots \ldots \ldots \ldots \ldots \ldots, 07$

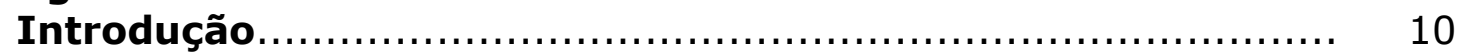

Objeto foco do trabalho $\ldots \ldots \ldots \ldots \ldots \ldots \ldots \ldots \ldots \ldots \ldots \ldots \ldots \ldots \ldots \ldots \ldots, \quad 10$

Questões e objetos da pesquisa....................................... 12

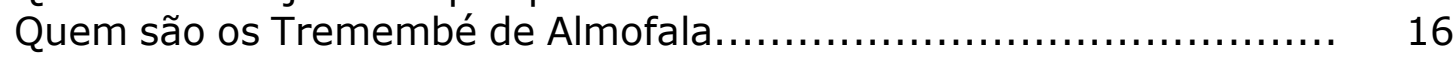

Práticas territoriais no cotidiano...................................... 18

Pressupostos teóricos............................................... 22

Procedimentos metodológicos (no trabalho de campo e na construção

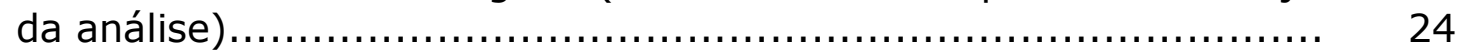

Breve resumo dos capítulos......................................... 26

\section{Capítulo 1.}

Mundos encantados: reflexões sobre a cosmologia Tremembé 28

1.1. Agentes não humanos identificados em Almofala.................. 30

1.1.1. Encantados..................................................... 30

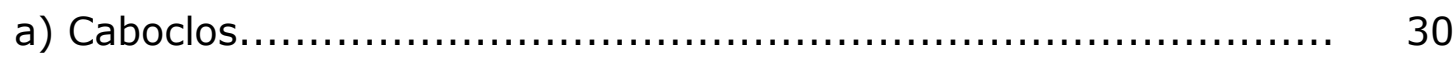

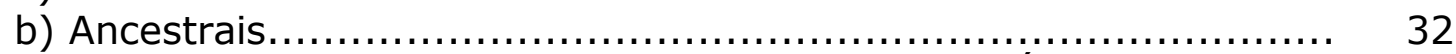

c) Encantados das matas: Caipora, Guajara e Mãe d'Água................ 34

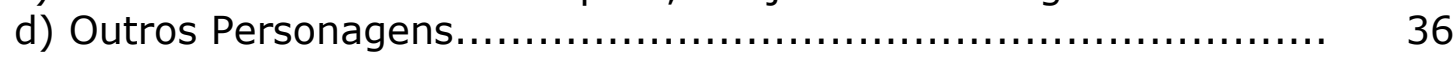

1.1.2. Assombrações ou Visagens.................................. 39

1.2. Trajetória em campo: conhecendo os Tremembé e seus mundos encantados.

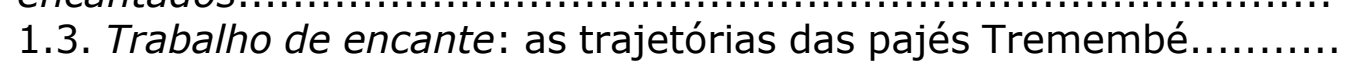

1.4. Rezadeiras e Curadores: a cura fora dos rituais de incorporação.

Capítulo 2. "Tem que ter ciência" - produção e circulação dos conhecimentos entre os Tremembé.

A natureza encantada dos Tremembé.

Sistemas de encante: os segredos dos mundos encantados................ "A gente escuta, mas não vê": Estratégias de acesso ao conhecimento.

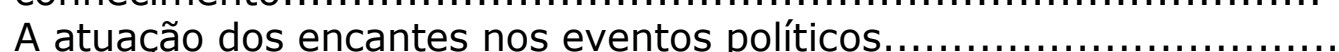

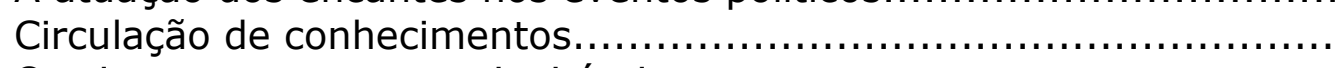

Os vivos, os mortos e os invisíveis

Capítulo 3. Dinâmicas territoriais dos Tremembé de Almofala Parte 1.

Histórico da ocupação dos Tremembé no litoral do Ceará................ 132

Terras da Santa..................................................... 137

Efeitos do agronegócio do coco .................................... 142

Atual cenário em Almofala dos Tremembé ............................ 144

Algumas considerações sobre a atividade agrícola entre os Tremembé.

Atuais alternativas de sobrevivência dos Tremembé...................... 163

Os encantados e as novas tecnologias ............................. 170 


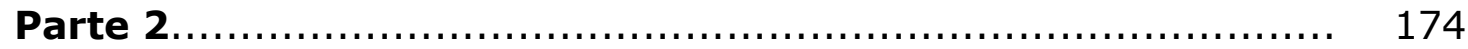

As formas de habitar a Almofala dos Tremembé........................ 174

Donos ou moradores............................................... 177

Conflitos ontológicos na Almofala dos Tremembé..................... 189

Considerações

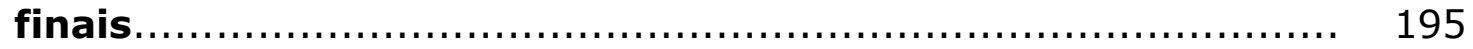

Bibliografia............................................................ 200

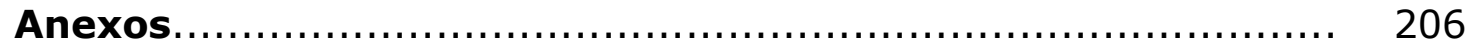

01. Mapa da Terra Indígena Tremembé de Almofala..... 207

02. Cronograma da pesquisa de campo.................... 208

03. Desenhos de crianças do Mangue Alto e da Praia de Almofala.................................................. 210 


\section{AGRADECIMENTOS}

Agradeço profundamente aos Tremembé que me acolheram em suas casas e compartilharam suas vidas comigo. Agradeço, especialmente, às crianças e adolescentes das Escolas do Mangue Alto e da Praia de Almofala que fizeram alguns dos desenhos que exponho nesta tese: Erieldo, Erivelton, Votória Caroline, Alexandre, Adriana, Mário, Miquelane, Iara, Lazirene e Camile.

À Dominique Gallois, minha orientadora, que abraçou com tanto entusiasmo a ideia desta tese desde que era ainda o esboço de um projeto. Pela confiança, a serenidade, a delicadeza, agradeço com carinho e admiração.

Aos membros da banca: Gerson Júnior - que, assim como eu, temse deixado levar pelos Tremembé em trilhas encantadas -agradeço pelas contribuições desde a época do mestrado; Joana Oliveira, pelas valiosas considerações durante a defesa do relatório de qualificação que foram fundamentais para o desenrolar deste trabalho. Ugo Maia, que abriu importantes espaços de interlocução para este trabalho nos GT's da ABA e da REA, coordenados por ele e Rosário. E Marta Amoroso, pela disponibilidade de contribuir com esta pesquisa. Agradeço a cada um dos membros pelo interesse e a presteza em contribuir com este trabalho.

À FAPESP, que possibilitou os subsídios materiais que tornaram esta pesquisa possível.

À Maninha, a pessoa que esteve mais próxima a mim nesses últimos e tão difíceis meses de escrita. Por todo o carinho, a paciência, o cuidado, o amor.

Às amigas Eloise Mudo e Danielle Cordeiro, que, desafiando toda distância, me socorreram em todos os momentos solitários desse doutorado. E à Luciana, que me hospedou durante o mês que estive em Paris. Agradeço demais às três pela força, o carinho e a amizade.

Pela hospedagem em Paris, agradeço também a Nicolas, Louni e Sallou que foram tão receptivos e atenciosos. 
Aos meus pais, pelo incentivo. Às minhas avós - Gonçalinha, Dedê e Didia - agradeço e peço perdão pela ausência durante os anos do doutorado.

Ao meu irmão, Walfrido, e minha cunhada, Lorrayne, pelas fotos e vídeos que encheram de graça esses últimos dias angustiantes de escrita. E meu sobrinho, Walfrido Filho, que me mostrou uma forma de amor que eu nunca imaginei que existisse. Muito grata por esse sorrisinho que leva embora todos os problemas e me fazem transbordar de alegria.

Em Fortaleza, quero fazer um agradecimento muito especial aos amigos que sempre me acolheram de braços abertos nessas minhas andanças durante o doutorado: Vinícius, Shamya, Luís, Marina e Fabi. Agradeço também a Aldinho, por abrir suas portas para as práticas de yoga que me ajudaram a redescobrir meus movimentos e meus limites e, assim, manter o equilíbrio necessário à escrita dessa tese.

Aos meus futuros colegas de trabalho, Camila, Monalisa, Emanuel, Igor e André. Agradeço com os votos de que nossa longa espera tenha um fim breve para que possamos iniciar essa nova jornada de nossas vidas com o pé direito!

Em São Paulo, tive uma legião de apoiadores queridos que tornaram possível a concretização deste trabalho: Lindomar e Flavinha, os embaixadores dos cearenses universitários em São Paulo, agradeço por todo o apoio, desde a seleção para o ingresso no doutorado. À Silvia, não só pelas milhões de vezes que - junto com Violeta e Cida, às quais também sou imensamente grata - me hospedou, mas pela torcida fiel desde a graduação. Ela e Marina sempre foram super confiantes e entusiastas desse projeto! E à Rita Mudo, que também sempre abriu as portas da sua casa todas as vezes que precisei em Fortaleza ou São Paulo.

No começo do doutorado, tive a sorte de conhecer, através de Analu (a quem agradeço muito por isso!) a residência mais bacana da Vila Indiana! Às minhas companheiras de morada: Flávia e Pati, por me mostrarem que, definitivamente, há muito, muito amor em SP!!! À Pati também agradeço pela disponibilidade em me dar uma força em todas as 
vezes que precisei resolver coisas burocráticas estando longe de SP, muito grata por ter descascado esses abacaxis! Agradeço também a seu companheiro, Ricardo, pela torcida!

Na USP, agradeço aos secretários do CestA, Frank e Lucas, que sempre quebraram meus galhos e tanto me ajudaram a encarar a burocracia de entrega de relatórios e prestação de contas... À Ana Yano, pela disponibilidade em me ajudar todas as vezes que eu precisei; à Carolina Morais, pelo apoio moral, tão grato nesses últimos meses de escrita; à Lígia Rodrigues e a André Lopes, pelas interlocuções.

Agradeço também à professora Simone Simões, que me apresentou a antropologia e me inspirou a seguir esse caminho profissional.

A André Álcman, agradeço por estar sempre presente em todos os bons e maus momentos dessa jornada. Sem seu incentivo, seu carinho e seu amor - que suportou a distância e a ausência durante esses anos de doutorado - esse trabalho não teria sido possível. A ele, minha gratidão e meu mais profundo amor. 


\section{INTRODUÇÃO}

\subsection{Objeto foco do trabalho}

Nesta pesquisa, versarei sobre a forma pela qual os índios Tremembé de Almofala - na região do Vale do Acaraú, litoral oeste do Ceará - habitam os lugares identificados como moradas dos encantados. Encantados ${ }^{1}$ são entidades que permeiam as ontologias de vários grupos, muitos deles ameríndios, sobretudo na região Nordeste do Brasil, embora os registros sobre o termo sejam encontrados em todas as regiões do país ${ }^{2}$.

No caso dos Tremembé, tais entidades são caracterizadas de diversas formas - como fadas, personagens da realeza, animais ou membros do grupo que se encantaram (antes ou após a morte) - e habitam diferentes mundos. Quando estão no nosso plano, elas escolhem como moradas paisagens classificadas como naturais. Sendo a Almofala dos Tremembé um lugar entrecortado de praias, matas e manguezais, esses lugares são habitados não só por humanos, mas por diversas entidades que têm uma vida social semelhante à dos humanos, porém, diferente de nós, são invisíveis para a maioria das pessoas e vivem em um plano de existência no qual não são afetados pela passagem do tempo. Tais lugares são identificados, portanto, como moradas dos encantados. Pretendo compreender como os Tremembé estão interferindo sobre estes lugares diante das intensas transformações que estão atravessando e dos seus efeitos na gestão do seu território e nas suas práticas cotidianas.

\footnotetext{
${ }^{1}$ As categorias nativas serão grafadas em itálico.

2 É comum entre as populações indígenas que falam o português o uso do termo encantado para designar entidades espirituais. Praticamente todos os trabalhos antropológicos escritos sobre as populações indígenas no Nordeste do país faz alguma referência a mundos encantados, plenos de entidades e objetos invisíveis à maioria das pessoas. Podemos citar aqui alguns deles, tais como Alarcon (2013), Brasileiro (1996), Cavalcante (2010), Couto (2008), Oliveira (2006), Oliveira J. (1997), além de vários outros. Mas em outros contextos, fora do nordeste indígena também encontramos registro do uso do termo, como entre os Mura do Baixo Rio Madeira, na Amazônia Central (Amoroso, 2013), algumas populações no Baixo Oiapoque (Andrade, 2007), entre várias outros grupos espalhados por diversas regiões.
} 
Os dados apresentados no decorrer desta tese revelam que as paisagens de Almofala são plenas de encantes ${ }^{3}$ que dividem com os humanos o uso dos lugares, pois moram em lagoas, pedras à beira-mar, árvores (em geral cajueiros), lagamares, mangues ou no próprio mar. As entidades fazem desses lugares suas moradas e, como nós - humanos também interferem sobre eles. Portanto, aqueles que têm alguma conduta desrespeitosa com os encantados sofrem sérias retaliações. Os dados aqui expostos revelam que os Tremembé pressupõem que a interferência sobre os lugares deve ser mediada por relações que estabelecem com mundos encantados, pois muitos dos lugares onde há natureza têm donos, conforme exposto no depoimento de um rapaz, sobre uma pescaria que havia planejado com um amigo. Os dois saíram de casa na moto que havia comprado recentemente, chegando ao mangue, quebraram uns galhos e puseram-nos sobre o banco da moto, como forma de protegê-lo contra o sol. Depois disso, passaram ambos a procurar caranguejos pelo mangue, mas o trabalho foi em vão, pois voltaram para casa levando apenas alguns siris que mal serviam de refeição. Ao chegar em casa, o rapaz foi acometido de fortes dores no corpo e na cabeça que só foram curadas pelas rezas de uma pajé 4 a quem ele recorreu. A pajé o alertou de que ele havia levado uma pisa ${ }^{5}$ do Guajara, o encantado do mangue, que o havia castigado pelos galhos quebrados em vão, e, ainda, salientou que ele mereceu o castigo aplicado, pois não havia respeitado o encantado que ali mora.

As agências dos encantados, entretanto, não se restringem às retaliações impostas aos humanos, como veremos, elas se desdobram nas

\footnotetext{
3 O termo encante é usado de para se referir a qualquer coisa ou ser que possua encantamento.

${ }^{4}$ Geralmente, os Tremembé utilizam o termo pajé para se referirem às pessoas que trabalham com incorporação, sejam elas índias ou não. Em relação aos que praticam tais rituais, usam também os termos macumbeiro, pai ou mãe de santo ou pajé de trabalho. Às vezes também chamam de pajé as rezadeiras e rezadores que não trabalham com incorporação, mas que curam através de rezas. Há também um cargo político de pajé. Todos os grupos indígenas organizados politicamente em torno do movimento nacional ou regional, têm uma pessoa que ocupa o cargo de pajé e os representa nos eventos políticos. No caso dos Tremembé, essa pessoa é o Luís Caboclo, que pratica atividades curativas com rezas e garrafadas.

${ }^{5}$ Uma surra.
} 
redes de relações que procurei investigar ao longo deste trabalho. Os encantados podem, eventualmente, ser malévolos, pois têm o poder de lançar feitiços, mas, em geral, atuam no auxílio das dificuldades cotidianas vividas pelos membros do grupo - curam doenças, reatam amores, arranjam trabalho, afastam maus espíritos... Alguns deles são membros do grupo que, após a morte, incorporaram-se em algum animal e continuam, assim, materializados neste mundo. Há outros que, mesmo não tendo necessariamente atravessado a experiência da morte, passaram a viver numa dimensão encantada, que pode estar, muitas vezes, bem próxima a nós, embora seja invisível para a maioria das pessoas. Enfim, são os modos de caracterização dos encantados são diversos, mesmo porque, a cada dia, podem surgir novas agências e relações entre os humanos e não humanos, numa miríade de possibilidades.

Entre as múltiplas relações estabelecidas entre humanos e encantados, darei destaque, no decurso desta tese, à análise das narrativas e das práticas cotidianas no trato com as moradas dos encantados.

\subsection{Questões e objetos da pesquisa}

A constatação de que os encantados são donos dos lugares suscita importantes reflexões, entre elas pensar sobre o que significa para os Tremembé o lugar de dono atribuído a estes seres. Qual o sentido da posse exercida pelos encantados em relação aos lugares os quais eles escolhem para viver? Qual o papel que eles desempenham enquanto donos daqueles espaços? Quais relações esse lugar de dono pressupõe? Faz-se fundamental refletir sobre estas questões para que possamos desvendar as relações que humanos e não humanos estabelecem entre si e com o lugar onde vivem. Alguns trabalhos já desenvolvidos na Amazônia indígena sobre a categoria dono iluminam muitas das questões aqui expostas. A categoria dono já foi foco de muitas pesquisas sobre povos indignas amazônicos ${ }^{6}$, no

${ }^{6}$ Bonilla (2005), Fausto (2008), Gallois (1988) e Sousa (2009) 
último capítulo da tese, lançarei algumas reflexões sobre o caso dos Tremembé, a partir de uma comparação controlada com casos amazônicos.

$\mathrm{Na}$ medida em que os encantados escolhem certa área como morada, trazem para ela objetos igualmente encantados, como pedras, búzios e, até mesmo, imensos castelos de ouro. Assim, em meio à paisagem que todos nós conseguimos enxergar, erguem-se paisagens invisíveis à maioria das pessoas, ou seja, os lugares estão sujeitos não só às ações humanas, como também, às dos encantados. No depoimento a seguir, Dona Zeza - índia Tremembé que foi uma das principais lideranças no processo de emergência étnica e atualmente beira dos 80 anos - fala de uma pedra, encontrada por pescadores durante uma pescaria em uma das lagoas da região, conforme descreve:

Quando chegaram lá [na lagoa] fizeram uma balsa de tabuba [Typha domingensis] e foram pescar, quando a balsa topou numa pedrona bem por acolá... e ela vinha afinando, vinha afinando e ficava só aquele pilão, aquela boca... Aí disse que eles se encostaram na boca e ficaram olhando a pedra cheia de piabinha entrando e saindo, aquelas piabinha preta... mas a pedra era por acolá [bem grande]. Olharam, olharam e foram pescar, quando voltaram disse que andaram essa lagoa todinha e não acharam mais a pedra.(...) Era encantada!

E Dona Zeza encerra o depoimento contando que o segredo do sumiço da pedra está no fato de ela pertencer à Mãe d'Água (ou Sereia), por isso, sempre que a encantada muda de lugar, a leva consigo. De acordo com ela, esta entidade escolhe como principais moradas duas das lagoas da região - a Lagoa Verde e a Lagoa Luís de Barros - e vai mudando de uma para a outra conforme a vazão das marés.

As moradas dos encantados também são caracterizadas de diferentes formas. Eles atravessam diferentes mundos e percorrem, obviamente, diferentes caminhos, mas, por onde quer que andem, estão sempre em meio aos elementos da natureza - mares, astros, matas...

A presença dos encantados é, pois, fato cotidiano. 
Isso posto, o que pretendo investigar nesta tese é de que forma os Tremembé levam em conta a presença dos encantados no contexto atual de intensas transformações em suas práticas territoriais, decorrentes da redução das áreas dedicadas à agricultura; da necessidade de construção de novas moradias - que antes eram, na grande maioria de taipa e palha e atualmente são de alvenaria; das disputas territoriais com fazendas de coco e camarão e com empresas de energia eólica; entre outros. Analisarei, assim, como os Tremembé constroem seus argumentos e decisões no que toca à gestão de seu território, lançando mão de elementos de sua cosmologia.

Há muito as lideranças exigiam do Estado providências quanto a melhores condições de moradia - já que a grande maioria das casas era de taipa ou palha com piso de areia e não tinham condições sanitárias, como banheiros, água encanada ou esgoto - e acesso a tecnologias como eletricidade e internet. Nos últimos anos, algumas reivindicações pleiteadas pelas lideranças do grupo foram atendidas, dentre elas, a chegada de água encanada e luz elétrica. Na maioria das localidades da região ${ }^{7}$, já havia energia elétrica há aproximadamente dez anos, mas muitas delas, como a localidade da Praia de Almofala e da Passagem Rasa, só tiveram acesso à luz elétrica há poucos anos, mais exatamente, no ano de 2008, quando foram contempladas com o Programa "Luz para Todos" do Governo Federal. Depois da energia elétrica, artigos como geladeira e televisores se espalharam por quase todas as casas, trazendo com elas mudanças significativas no cotidiano do grupo.

Além de a chegada da eletricidade, outras mudanças profundas têm ocorrido nas paisagens de Almofala, decorridas, por exemplo, do aumento da renda e do consequente aumento do consumo; do aumento da

\footnotetext{
7 A região da Grande Almofala compreende várias localidades, as quais os membros do grupo dividem entre as da praia - Praia de Almofala, Barro Vermelho, Lameirão, Panã, Camboa da Lama, Mangue Alto, Aningas do Mulato, Cabeça de Boi, Passagem Rasa, Curral do Peixe, Urubu e Boa Vista - e as das mata -Varjota (Varjota, Tapera, Batedeira I e II, Praia do Caboré, e Camondongo) e Córrego João Pereira (São José, Capim Açu e Cajazeiras). No anexo 01, apresento um mapa da área.
} 
quantidade de lixo que se aglomera a céu aberto em algumas áreas, já que não há coleta de lixo nessas regiões, e da intensificação da atividade turística ${ }^{8}$, sobretudo após a construção da estrada que liga a Praia de Almofala à principal estrada do litoral oeste, que gerou uma proliferação de barracas de praia9 ${ }^{9}$. Além disso, há vários outros fatores que contribuem com a depredação ambiental na área dos Tremembé, entre eles, a pesca predatória, as fazendas de coco, os criatórios de peixe e camarão e, mais recentemente, a construção de parques de energia eólica no entorno da área.

Estas mudanças são muito recentes e suas causas e consequências merecem ser investigadas. Geralmente, as pesquisas que abordam os efeitos do desenvolvimento nas Terras Indígenas no Nordeste debruçam-se sobre grandes empreendimentos, como a construção de hidrelétricas, de parques de energia eólica ou a transposição do rio São Francisco. Em Almofala, até bem pouco tempo, a comunidade não sofria com a construção de obras dessa magnitude, todavia, a própria dinâmica interna da comunidade - diante do aumento do emprego formal, que provocou um aumento no consumo de produtos industrializados (gerando, em consequência disso, a produção de um número bem maior de resíduos sólidos) - já suscitavam mudanças nas dinâmicas territoriais. Nos últimos dois anos, porém, duas empresas entraram com um processo de licenciamento nos órgãos competentes para a construção de dois parques eólicos na região de Almofala. No projeto, apesar de os parques estarem fora da Área Indígena (AI), o canteiro de obras das construções da infraestrutura para a instalação dos aerogeradores a atingem e podem

\footnotetext{
8 É preciso ressaltar, porém, que a Praia de Almofala não está no circuito turístico cearense, pois não há muitas pousadas na vila (somente duas) e nenhum hotel. Assim, os visitantes que procuram as praias da região nos finais de semana são, em geral, moradores das cidades mais próximas ou estudantes curiosos em conhecer a área indígena. Ainda assim, nos finais de semana, as praias recebem um grande número de pessoas que deixam um lastro de sujeira nas areias à beira-mar.

${ }^{9}$ As barracas de praia são restaurantes à beira mar cuja estrutura garante aos frequentadores banheiros e mesas - geralmente com guarda sol - e cadeiras dispostas na faixa de areia. Necessitam, portanto, de um quadro de funcionários semelhante aos dos restaurantes convencionais, cozinheiros, garçons, faxineiros, etc.
} 
comprometer seriamente olhos d'água, córregos, lagoas, mangues e riachos que perpassam a Área e são essenciais para a sobrevivência dos seus moradores.

\subsection{Quem são os Tremembé de Almofala}

Os Tremembé de Almofala são cerca de 2,2 mil pessoas que vivem em uma pequena terra indígena de 4.900ha. Trata-se de uma área litorânea situada na região do Vale do Acaraú, litoral oeste do Ceará, município de Itarema, distrito de Almofala, no nordeste brasileiro. A área foi identificada e delimitada no começo dos anos 90, entretanto, até hoje os índios ainda lutam pela demarcação que deverá garantir a posse definitiva do território que vem sendo alvo de muitas disputas envolvendo principalmente a empresa Ducoco - indústria de beneficiamento de coco que ocupa mais de um terço da área indígena - e a família Monteiro família influente na política local e que tem intermediado a instalação de parques eólicos com o interesse de arrendar suas terras para a instalação dos mesmos.

A pesca artesanal e a agricultura familiar constituem o principal meio de sobrevivência do grupo, muito embora, nos últimos anos, alguns empregos formais - sobretudo como agente de saúde, agente sanitarista e professores nas escolas diferenciadas - tenha aumentado significativamente. Há também muitas mulheres que eventualmente trabalham como domésticas, mas praticamente todas elas não chegam a ganhar um salário mensal e nem tampouco têm a garantia de quaisquer direitos trabalhistas.

Há registro de contato entre europeus e os Tremembé desde a chegada dos primeiros invasores, quando, segundo os relatos dos viajantes, estes índios ocupavam a área litorânea que compreende os atuais estados do Maranhão, Piauí e Ceará (POMPEU SOBRINHO, 1951). Mas tal contato se intensificou somente no início do século XVIII, quando a Irmandade de Nossa Senhora da Conceição iniciou um trabalho de 
evangelização com os índios da região, contudo, pouco se sabe sobre a organização desse aldeamento, pois, como não se tratava de uma ordem jesuítica, os registros encontrados são muito escassos (POMPEU SOBRINHO, 1951; STUART FILHO, 1963; VALLE, 1992).

Com a expulsão dos jesuítas pelo Marquês de Pombal, as terras do aldeamento ficaram devolutas. Desde então, a historiografia oficial silencia sobre a presença indígena na região, defendendo a tese do total desaparecimento de tais povos. Nos anos de 1970, entretanto, a organização política de grupos indígenas que acompanhavam um momento de grande efervescência não só no Brasil, mas em toda a América Latina - onde diferentes categorias engrossavam o coro das reivindicações por seus direitos civis - surpreendeu as previsões sobre o desaparecimento dos índios no Ceará. Foi nesse contexto que, no início da década de 80 , os Tremembé de Almofala, ao lado de mais três etnias - Tapeba, JenipapoKanindé e Pitaguary -, começaram a se organizar enquanto movimento indígena no estado. Hoje, mais de quinze grupos se somam a essa luta, entre eles outros grupos Tremembé, nas proximidades de Almofala, na região do Vale do Acaraú.

O reconhecimento dessa identidade garante a esses grupos o acesso a políticas de saúde e educação específicas, além da posse das terras que ocupam. No caso aqui exposto, os serviços de saúde e educação diferenciados têm sido uma das principais conquistas apontas pelas lideranças Tremembé, entretanto, o processo de demarcação da Terra Indígena permanece atravancado há mais de duas décadas ${ }^{10}$.

Como acontece com vários outros grupos indígenas nas Américas, os Tremembé não apresentam traços muito diferenciados em relação à população não índia da região, e essa baixa contrastividade é o principal

\footnotetext{
10 Vale lembrar as diferenças entre as noções de terra e de território. Conforme aponta Gallois (2004) "a noção de 'Terra Indígena' diz respeito ao processo político-jurídico conduzido sob a égide do estado, enquanto à de 'território' remete à construção e a vivência, culturalmente variável, da relação entre uma sociedade específica e sua base territorial." (p. 39).
} 
argumento utilizado no âmbito judicial para lhes negar a posse das terras com base no argumento da "aculturação", ou seja, da perda da identidade indígena. Diante dessas dificuldades, as lideranças lançam mão da noção de "cultura" para respaldar suas reivindicações. Assim, eles identificam nas suas práticas cotidianas elementos de diferenciação os quais eles compreendem como sendo os aspectos "tradicionais de sua cultura", que operam e ganham significados de acordo com necessidades e experiências vivenciadas na atualidade. Carneiro da Cunha (1986), ao tratar do assunto, assevera que não se pode compreender a tradição como a simples reprodução de elementos trazidos de um passado estático. Numa discussão mais recente (2009), ela analisa diversas situações em que os índios se apropriam da categoria "cultura", num processo em que elegem elementos de distinção e reivindicam, através deles, demandas políticas específicas. Tais elementos são, portanto, desconstruídos, construídos e reconstruídos de acordo com a dinâmica cotidiana, num movimento que parte de uma experiência atual. É a partir das necessidades atuais que os grupos acionam uma memória que, por sua vez, irá reelaborar o passado, legitimando e ordenando a realidade presente.

É preciso ressaltar aqui, entretanto, que não pretendo tratar as diversas concepções e práticas sobre as moradas dos encantados entre os Tremembé somente a partir a questão étnica, pois, conforme aponta Gallois (2004), trabalhar com a noção da territorialidade permite ir além da questão identitária, da relação com o Estado, permitindo alcançar a compreensão e as práticas nativas de território com suas variações.

\section{Práticas territoriais no cotidiano}

Nos discursos das lideranças políticas do grupo, vários elementos são, portanto, elencados como símbolos de distinção frente à sociedade circundante, entre eles, os chamados trabalhos de encantados. Em praticamente todos os trabalhos sobre os índios no Nordeste (BRASILEIRO, 1996; PAIVA E SOUZA, 1992; SOUZA,1996), estas entidades são citadas 
como elemento essencial na cosmologia dos grupos, entretanto são raras as pesquisas que aprofundam a especificidade desses mundos encantados, que, mesmo diante da vastidão de trabalhos produzidos sobre estes grupos, continuam constituindo uma lacuna ${ }^{11}$.

Desde o início dos anos 80, as produções acadêmicas sobre índios que vivem no Nordeste abordam, em geral, o processo de organização política desses grupos, deixando os sistemas simbólicos produzidos pelos mesmos em segundo plano e abordando o tema da cosmologia de forma rápida e superficial. Quando se toca no assunto, geralmente, o trabalho escrito por Nascimento (1994) é a referência mais citada. Sua dissertação toma o "complexo ritual da Jurema" como unidade de análise para um entendimento aprofundado dos ritos praticados pelos índios na região, elaborando um estudo de caso sobre a adoção pelos Kiriri, na Bahia, ao ritual do toré. Entretanto, embora seja um trabalho de grande fôlego e desenvolvido com maestria, seu intuito não era abordar a cosmologia dos Kiriri, mas a articulação entre ritual e etnicidade. Após a fenda aberta pelo autor sobre o tema, houve uma tendência nos trabalhos escritos posteriormente em analisar as práticas rituais desses índios como sendo uma derivação automática do caso Kiriri e enquadrá-las no que Nascimento denominou de "complexo ritual da Jurema". Atualmente, entretanto, mais de vinte anos depois de publicada a referida dissertação, o que observo nas práticas indígenas é uma enorme diversidade nas manifestações e agências de encantados. Urge, pois, a necessidade de abordar o assunto da encantaria entre esses grupos para além da questão identitária, centrandose especificamente nas suas cosmologias. E é isso que pretendo fazer na proposta que aqui apresento.

\footnotetext{
${ }^{11}$ No Ceará, em especial, os trabalhos de Cavalcante (2010) e Oliveira Jr. (2006) abordam o assunto dos encantados, mas ambos optaram por uma abordagem bem diferente da que pretendo desenvolver, pois o primeiro - uma etnografia sobre os Tapeba, em Caucaia, região metropolitana de Fortaleza - centrou-se nas narrativas das mulheres marisqueiras que trabalham no mangue, enquanto o segundo focou a questão da pesca entre os Tremembé de Almofala.
} 
Há uma enorme variedade de práticas nas quais os pajés recorrem aos encantados, desde trabalhos nos quais há a incorporação cuja finalidade é praticar a cura de doenças ou tirar encostos (afastar entidades sobrenaturais que, por algum motivo estejam a prejudicar alguém) através dos encantados, até os trabalhos de reza, nos quais não há a incorporação. Outrossim, aparecem para os pajés, às vezes também em sonhos, para ensinar remédios (em geral obtidos da flora local), dar conselhos ou lançar previsões. Além do termo trabalho de encantados, os membros do grupo utilizam várias outras denominações para se referirem a tais rituais, como tundá e Umbanda. Entretanto, sobretudo nos discursos políticos, as lideranças procuram salientar as diferenças existentes entre tais rituais e os rituais umbandistas, tratando os trabalhos de encantados como sendo algo intrinsecamente indígena.

Já há alguns anos, pude observar que o cacique costuma iniciar os eventos políticos com uma prece dedicada aos encantados ${ }^{12}$. Nos discursos das lideranças, as categorias de lugar sagrado, mata virgem, natureza ou terra encantada aparecem frequentemente para respaldar suas reivindicações. A questão que levanto é: e nas práticas cotidianas, como tais categorias são tratadas?

Evidentemente, não estou afirmando que os índios estabelecem uma relação completamente equilibrada no uso dos recursos, mas que as narrativas em torno dos encantados buscam recompor este equilíbrio, conforme será evidenciado nas narrativas que exponho na sequência.

Contam-se muitas histórias sobre pessoas que sofreram represálias depois de terem tido alguma conduta desrespeitosa em relação aos lugares onde moram os encantados. Para os Tremembé, conforme demonstra o depoimento abaixo, os encantados protegem suas moradas de ações predatórias:

\footnotetext{
${ }^{12}$ A prece diz o seguinte: Não tem caminho que nós não ande / Nem tem rio que eu não atravesse / Não tem pau que eu não arranque / Nem tem pedra que eu não quebre / E não tem mal que eu não cure /Viemo lá das cachoeiras /Com a força da natureza /Os encantado nos mandou /Viemo aqui fazer limpeza
} 
(...) uma vez eu tava brocando esse mato aí, aí era um bando de homem, aí eu tava arrancando uns toco num pé dum juazeiro, o juazeiro já tinha caído, eu comecei a desgalhar, cheguei com a foice, né, quando taquei a foice assim no galho do juazeiro, aí uma voz disse assim: "ei, por que é que vocês tão derrubando minha morada?" (Francisco, 2009)

Nos relatos, ocorrem tanto casos em que as pessoas são repreendidas por não terem tido a conduta devida em relação aos espaços dos encantados, como casos em que tais entidades recompensam as pessoas pelas oferendas a eles prestadas antes de adentrarem nas suas moradas.

Ou seja, a análise das relações que fundam a cosmologia revela saberes e práticas que orientam a conduta dos índios em relação aos recursos. Assim, as reflexões propostas por Descola, quando se refere às mitologias dos povos amazônicos, será de grande valia para o desenvolvimento da proposta que ora apresento. $O$ autor, em sua etnografia sobre as roças dos Ashuar, atentou, pioneiramente, para a inadequação do modelo naturalista de pensar natureza e cultura como instâncias autônomas, pois esta visão estaria levando os estudiosos a procurar nas populações ameríndias algo que não existe: um termo que separe natureza e cultura (DESCOLA, 1986). Longe de idealizar a noção de natureza intocada comumente reforçada quando se fala em Amazônia, o autor toma a natureza enquanto produto de uma relação social, estando, portanto, num perpétuo vir a ser, para ele, sendo a natureza um "prolongamento do mundo da casa, ela é verdadeiramente doméstica, até em seus redutos mais inacessíveis" (DESCOLA, 2000, p.152). Deste modo, a polarização natureza versus cultura configura-se estéril para a Antropologia, posto que estes dois polos não constituem categorias opostas, ao contrário, as entidades que compõem o universo "só possuem um sentido e uma identidade mediante as relações que as instituem como tais" (DESCOLA, 2000, p.163). 
Considero indispensável compreender como esses os Tremembé habitam suas terras. Terras estas povoadas por diferentes agências e subjetividades que surgem cotidianamente nas relações com os humanos.

\subsection{Pressupostos teóricos}

É importante esclarecer que compreendo os encantados como agentes plenos de intencionalidade. Pretendo, então, lançar-me ao exercício de uma antropologia simétrica, nos moldes propostos por Latour (1994), quando postula que a antropologia, enquanto uma ciência fundada no contexto da modernidade para compreender os não-modernos, introjetou nos seus conceitos e práticas a distinção entre natureza e cultura, permanecendo assimétrica, na medida em que evitava estudar os objetos da natureza e se limitava ao estudo das culturas. Para torná-la simétrica, precisamos estar situados num ponto intermediário, de onde possamos observar a atribuição de propriedades humanas e, também, não humanas. Reconstruir-se tomando como partida o princípio da simetria tem sido um dos grandes desafios lançados à antropologia contemporânea, e o que pretendo é, também, lançar-me a este desafio, trazendo os encantados, bem como os elementos a eles associados - as águas, areias, conchas, matas, pedras e árvores de Almofala - para o centro da vida social dos Tremembé. Compreendê-los não somente como uma representação social, mas como agentes plenos de intencionalidade e que interagem com os seres visíveis, formando complexas redes de relações.

Assim, proponho-me, neste trabalho, a saltar em um enorme abismo aberto ao longo da história das ciências entre o humano e o natural. Os encantados, conforme veremos no primeiro capítulo não somente controlam os fenômenos e as coisas que classificamos como "naturais", eles são as coisas em si. Ao se referirem às plantas, por exemplo, eles apresentam suas propriedades curativas como o encante da planta. Segundo vários depoimentos colhidos, cada planta tem seu encante, mas 
só alguns conseguem percebê-los através de uma série de habilidades que vão desenvolvendo na interação com o mundo.

Interagir com as plantas e os lugares, é, antes de tudo, uma experiência sensorial. Não se trata, portanto, somente de criar representações sobre o mundo e tudo que o cerca, mas de compreender a relação entre o ser e o mundo, como mutuamente construída. Assim, as considerações propostas por Ingold (2000) serão muito caras a esta pesquisa. Buscando inspiração na fenomenologia de Merleau-Ponty, Ingold concebe a relação homem-mundo como sendo recíproca e multissensorial; que envolve o ver, o falar, o escutar, o tatear, o cheirar... Enfim, todos os sentidos são mobilizados na percepção do ambiente, percepção esta, é preciso ressaltar, que ele não apreende como sendo apenas uma forma de dar significado ao mundo, mas uma experiência através da qual o ser humano vai desenvolvendo habilidades, ou seja, ele busca desconstruir a ideia de um ser abstrato que dá sentido ao mundo para dar lugar a um ser no mundo.

O que pretendo é desvendar quais questões os Tremembé formulam na lida com os lugares, salientando que considero as relações estabelecidas entre todos os agentes - humanos e não humanos envolvidos nessas disputas enquanto relações sociais, posto que os lugares, bem como as entidades que neles moram, têm agência. Os lugares não são inertes nem, tampouco, estão à mercê das vontades humanas, ao contrário, muitos dos seus elementos - visíveis ou invisíveis - podem ser alterados dependendo da decisão dos encantados.

$O$ acesso aos mundos encantados se efetiva a partir da interação com lugares como matas, mangues, dunas e águas. Estes lugares são palco de todas as histórias que me foram contadas sobre os encantados. Por isso, para compreender tais relações, foi necessário imergir nesses lugares, perceber como os Tremembé agiam sobre eles, com eles, através deles... Por isso, as considerações propostas por Ingold (2015) acerca das ideias de espaço, lugar e movimento foram essenciais para o desenvolvimento das reflexões postas ao longo da tese. Posicionando-se radicalmente contra 
a noção de espaço, ele a compreende como sendo resultado de uma lógica de inversão, que "transforma as vias através das quais a vida é vivida em limites dentro dos quais ela está encerrada" (p. 215). A mesma lógica de inversão transforma os modos de conhecer em transmissão de padrões culturais. O conhecimento, para ele, não é transmitido através das gerações, é sim, antes de qualquer coisa, construído e reconstruído nas práticas cotidianas.

Para alcançar, portanto, as formas como os Tremembé conhecem e vivenciam cotidianamente os lugares que dividem com os encantados, é necessário focar nos movimentos de peregrinação através deles. Os lugares, portanto, são delineados pelo movimento e não pelos limites exteriores a ele (p.220).

Algo essencial a esclarecer logo no início deste trabalho é o fato de que, se recorro aqui à oposição humanos e encantados é por não ter achado uma melhor forma de me referir a essa distinção. Entretanto, como veremos, essa separação é cheia de nuances e imbricações, pois esse universo encantado não é composto por dois mundos que se opõem: vivos e mortos, humanos e não humanos, visíveis e invisíveis, terreno e sobrenatural... O que vemos são vários mundos que coexistem, ora se opõem e ora se relacionam entre si. Por isso recorreremos à noção de ontologias múltiplas propostas por Annemarie Mol (2007), que compreende o mundo não como sendo dado a priori, mas forjado performaticamente e cotidianamente pelas práticas, daí não usarmos o termo "mundo" no singular, pois as práticas modelam diferentes mundos que se põem em contato.

\subsection{Procedimentos metodológicos (no trabalho de campo e na construção da análise)}

No debate antropológico acerca das relações entre "natureza" e "cultura", é ponto pacífico que a visão naturalista que coloca esses domínios em polos opostos, tratando-as como categorias autônomas e estanques é uma 
noção ocidental com a qual o pensamento e as práticas ameríndias não corroboram. Evidentemente, porém, o debate não se encerra nisso, o ponto central desta discussão atualmente gira em torno da noção de contínuo e descontínuo entre natureza e cultura. Enquanto autores como Descola - que se propõe a revisitar o conceito de animismo - interpretam o pensamento ameríndio como estabelecendo uma continuidade entre essas duas categorias; outros pesquisadores, seguindo o modelo perspectivista proposto por Viveiros de Castro, chamam atenção para o fato de que, embora as cosmologias amazônicas ressaltem a constante relação entre humanos e não humanos, que estão, a todo momento, estabelecendo comunicação, por outro lado, elas ressaltam a importância da separação entre pontos de vista, concluindo, assim que a noção de continuidade se torna imprópria para analisar a questão, pois, embora a comunicação entre estas duas esferas seja constante, ela nunca é plena, há sempre a necessidade de se colocar tais mundos como separados. Desta forma, a análise das relações estabelecidas entre humanos e não humanos em Almofala nas lidas com as moradas dos encantados irá lançar luzes sobre este debate, a partir de materiais não-amazônicos, que podem constituir uma contribuição inovadora ao debate dos modelos mencionados acima.

Desde os anos 80, a Antropologia vem passando por um processo de autorreflexão no qual importantes questões acerca da relação entre pesquisador e pesquisado têm sido reformuladas. Todavia, muitas destas questões permanecem inerentes à dificuldade de traduzir a cultura nativa, expressá-la, descrever esse nativo. Uma alternativa que considero essencial para a proposta ora apresentada é a apontada por Wagner, que sugere a reconceitualização do exercício antropológico que, ao invés de se limitar a tornar as sociedades primitivas compreensíveis aos olhos da sociedade ocidental, deveria também fazer um caminho inverso, alcançando as elaborações nativas sobre o Ocidente. Para Wagner nem a "cultura do nativo" nem tampouco a do antropólogo é algo dado, mas fruto da relação estabelecida pelos dois. Assim, ele tira o foco da cultura e coloca na alteridade, fazendo um caminho reverso, ele busca alcançar as questões elaboradas pelos nativos e é seguindo esse caminho que pretendo desvendar como os Tremembé vivenciam seus lugares. 
Uma preocupação recorrente nas minhas conversas com os Tremembé sobre os encantados era o fato de que eles estariam deixando os lugares em Almofala, na medida em que avançam os problemas ambientais na região. Essa inquietação suscitou a mim uma série de reflexões sobre a agência dos encantados, suas atribuições enquanto donos de suas moradas, quais os limites das suas ações em relação aos lugares onde moram.

\subsection{Breve resumo dos capítulos}

O primeiro capítulo desta tese será dedicado aos modos de caracterização das entidades não humanas que habitam a Almofala dos Tremembé. Até então - no projeto de seleção do doutorado e no relatório de qualificação - eu estava tratando os não humanos dentro de uma categoria ampla e abstrata: encantados. Isso gerava uma confusão no que diz respeito às suas agências e as relações estabelecidas com eles e entre eles, pois tratam-se de entidades diversas que estabelecem relações específicas com os humanos nos momentos em que se manifestam. Consegui identificá-las em duas categorias: encantados e assombrações ou visagens. Os primeiros se dividem entre os caboclos, os ancestrais dos membros do grupo, os moradores das matas - Caipora, Guajara e Mãe d'Água - e algumas entidades descritas como personagens de contos de fadas. Já as assombrações, embora também circulem pelas mesmas paisagens que os encantados, não têm livre acesso aos segredos da natureza, capacidade inerente aos encantados; nem, tampouco, são caracterizados enquanto donos dos lugares onde vive. Ao contrário, eles estão vagando pelos lugares, perdidos, sem saber que rumo seguir... São espíritos malignos, encostos ou sombras, que, em geral, se aproximam dos vivos - humanos - para pedir ajuda em relação a algum problema pendente que não conseguiram resolver em vida. Ressalto, contudo, que tais entidades surgem a todo momento, portanto, não intento fazer aqui uma classificação de seres, mas, tão somente, descrever as múltiplas 
subjetividades e agências que me foram apresentadas na experiência de campo ${ }^{13}$.

Os encantados se manifestam basicamente em três situações, nas práticas curativas, nos eventos políticos do grupo e no trato cotidiano com suas moradas. Tratarei nesse capítulo das curas praticadas por eles através dos pajés, nos rituais de Umbanda, e outros rituais que não envolvem incorporação, como as rezas.

No capítulo seguinte, tratarei de algumas implicações das relações entre humanos e encantados no que diz respeito à produção e circulação de conhecimento, que passa, também e sobretudo, pela noção de cura. As propriedades curativas das plantas são encantes que se revelam aos poucos, a depender da necessidade dos humanos. Estas revelações envolvem habilidades desenvolvidas pelos humanos na lida com o ambiente adquiridas nas relações com encantados e suas moradas.

O terceiro capítulo será dividido em duas partes. Na primeira, tratarei das dinâmicas territoriais e das áreas onde os conflitos agrários são mais acirrados. A partir desses conflitos, podemos entender o que está ocorrendo atualmente com as moradas dos encantados, áreas diretamente impactadas pelas ações predatórias de vários segmentos do agronegócio que se instalaram ali. Evidentemente, nesta parte do texto, embora esteja descrevendo as dinâmicas espaciais vivenciadas pelos Tremembé, não perderei de vista as atuações dos encantados nesses processos, ressaltando, mais uma vez, que, assim como os humanos, também eles sofrem com as ações predatórias postas em prática na Área Indígena. $\mathrm{Na}$ segunda parte do capítulo, farei uma análise das diferentes formas de habitar a Almofala dos Tremembé que pude identificar através dos movimentos de perambulações com meus interlocutores em campo. Para tanto, analisarei o cotidiano de algumas famílias que frequentam com mais assiduidade tais lugares e a forma como se movimentam pelas várias localidades que compõem a área.

${ }^{13}$ Sobre meu trabalho de campo, esclareço que o cronograma das etapas está no primeiro anexo da tese. 


\section{MUNDOS ENCANTADOS: REFLEXÕES SOBRE A COSMOLOGIA TREMEMBÉ}

Conforme já anunciado, neste capítulo apresentarei minha trajetória em campo, desde meus primeiros contatos com os Tremembé até hoje e sobre como, neste percurso, fui tomando conhecimento de manifestações encantadas que se desenrolam em Almofala. Tentarei elucidar algumas das principais questões que orientam esta pesquisa, no que diz respeito às agências dos encantes. O que eles fazem nestes mundos? Quais suas atribuições, seus poderes, como se manifestam e quais relações estabelecem com os outros habitantes do lugar? Seriam eles humanos? Em quais circunstâncias - e por quem - deixam-se ver? No trabalho de campo, quando passava adiante tais questões, as respostas eram bem controversas. Ora diziam que se tratavam de seres humanos, ora de não humanos, ora que eram espíritos de mortos, ora que eram entes que nunca morreram, se encantaram, ora eram visíveis, ora invisíveis... Logo entendi que, para compreender esse reino dos encantados, revelado na convivência com os Tremembé, teria que começar por aceitar a pluralidade inerente a ele, pois nos são revelados mundos onde alguns abismos aparentemente intransponíveis - como vida e morte, humano e não humano, por exemplo - tornam-se conciliáveis.

Escolher "por onde começar" a falar sobre este tema não foi uma tarefa fácil diante da profusão de manifestações que se expuseram a mim na experiência etnográfica. Resolvi, então, começar contextualizando o leitor em relação aos diversos agentes envolvidos nas questões aqui colocadas. Sobre os humanos, o foco aqui são os Tremembé, que já foram apresentados na introdução, portanto discorrerei neste momento sobre os não humanos que dividem com eles algumas áreas de Almofala. Farei, então, uma breve apresentação dos vários agentes que consegui identificar nas pesquisas de campo. Os pormenores das ações dos não humanos e das relações estabelecidas entre eles e os humanos serão tratadas no decorrer da tese, por ora o que pretendo é tão somente descrever alguns modos de 
caracterização de personagens que compõem os mundos encantados para, assim, tonar mais claras as questões que colocarei nos capítulos seguintes.

Em trabalhos anteriores, eu colocava todas as entidades descritas neste capítulo na categoria de "encantados", na escrita desta tese, entretanto, a necessidade de analisar mais acuradamente as diversas agências que identifiquei em campo se impôs na medida em que eu ia refletindo sobre os mundos dos encantes, pois percebi que colocar, por exemplo, as Mães d'Água lado a lado com os Caboclos da Umbanda - todos sob o "rótulo" de "encantados" - diluiria as diferenças das ações e manifestações características de cada um desses personagens. Ou seja, não pretendo aqui apresentar uma classificação de "tipos" de encantados, mas alguns personagens e agências que compõem as redes de relações entre humanos e não humanos que circulam pelas matas, águas e areais de Almofala. Ressalto que, evidentemente, não ambiciono mostrar como são esses universos encantados, entretanto exporei como eles foram revelados para mim na vivência cotidiana com os Tremembé.

Frente à pluralidade de descrições que me eram expostas sobre o tema, resolvi, como anunciado na introdução, seguir os percursos metodológicos propostos pela Teoria Ator Rede, ou seja, procurei seguir as redes de relações que se formavam a partir dos encantes. Essa trilha me levou a múltiplas realidades que coexistem. Nessas mais diversas realidades, novas entidades sociais surgem cotidianamente numa pluralidade infindável de seres e agências. Para descrever tantas diferentes manifestações que circulam a Área Indígena em questão, procurarei contextualizar suas aparições e as relações que estabelecem com os humanos. 


\subsection{Agentes não humanos identificados em Almofala}

Consegui identificar dois modos de caracterização ${ }^{14}$ de agentes não humanos que habitam as paisagens de Almofala. Os encantados - que se manifestam, de um modo geral, para trazer os benefícios da cura para os humanos ou para proteger suas moradas de possíveis invasores, sejam eles índios ou não. As assombrações ou visagens, que não atuam para ajudar os humanos nas dificuldades cotidianas - como fazem os encantados -, agem somente para assustá-los ou provocar alguma outra perturbação. 0 que há de comum entre eles é que todos habitam as mesmas paisagens de Almofala.

Nos próximos parágrafos, descreverei alguns desses agentes de acordo com o que pude identificar nos depoimentos coletados e nas observações do cotidiano das famílias Tremembé.

\subsubsection{Encantados}

Na sequência, exporei algumas das formas de caracterização dos encantados, entretanto, preciso ressaltar que novas entidades surgem a todo instante na interação com os humanos, seja nas moradas dos encantados ou nos rituais de cura.

\section{a) Caboclos}

As entidades que se se incorporam em pajés são, em geral, caboclos da Umbanda - também chamados de guias ou mestres - como Nêgo Gerson, Cabocla Jurema, Sete Flechas, Tapuia, Maria Padilha, Maria Molambo, Zé Pilintra, entre outros. Os pajés e as pessoas ligadas às práticas umbandistas classificam todas estas entidades como encantados.

\footnotetext{
${ }^{14}$ Saliento aqui que não trato como caracterização, mas como modos de caracterização, para, desta forma, ressaltar o caráter transformacional inerente aos mundos dos encantes.
} 
Entretanto, tais pessoas também não excluem desse grupo outros moradores das matas, como o Guajara, o Caipora e as Mães d'Águas, ainda que eles não baixem nos terreiros.

Descreverei ainda neste capítulo como se dão os rituais de incorporação, também chamados de tundá, trabalhos de encantados ou Umbanda. Por ora basta dizer que as entidades que neles se manifestam baixam para ajudar às pessoas que a elas recorrem em tais rituais. No geral, o intuito é a cura de enfermidades, problemas afetivos ou financeiros ou, ainda, para suspender as correntes de alguém que esteja se sentindo molestado pelo chamado dos encantados, ou seja, afastá-los, ainda que temporariamente, destas pessoas. A passagem do "outro mundo" para o "nosso" ocorre através das correntes e das linhas, falarei mais sobre elas ainda neste capítulo.

Tive a oportunidade, quando assistia a um trabalho de Seu Chico Brega, pajé que mora na localidade da Batedeira, de entrevistar alguns caboclos que nele se incorporaram. Eles me explicaram que moram em "outro mundo", mas, quando estão no mundo terreno, preferem ficar em lugares onde "há natureza", por isso estão sempre por perto, nas paisagens de Almofala. Comentaram também que são seres de "outros tempos", um tempo no qual, para redimi-los do sofrimento, deus os livrou da morte e os encantou, transportando-os a outras dimensões, nas quais eles podiam manter seus estados corporais, por isso eles têm corpos - diferente dos mortos, aos quais só resta a alma, enquanto os corpos perecem. Os corpos dos encantados, entretanto, transmutam-se em quaisquer formas, assim, eles podem mostrar aos humanos a aparência que Ihes for conveniente. Eles também têm o dom de tornarem-se invisíveis, por isso, às vezes, nos depoimentos, as pessoas faziam a oposição entre humanos e encantados nós e eles - como visíveis e invisíveis. 


\section{b) Ancestrais}

Entre os encantados também estão alguns familiares de membros do grupo que, mesmo após a morte, têm o dom de se encantar e, assim, adquirir a capacidade de circular por vários mundos. São pessoas que fizeram grandes feitos quando estavam vivas, por isso, conquistaram o mérito de poder continuar transitando entre os vivos para ajudá-los e protegê-los. Eles se apresentam a amigos e familiares sob diferentes formas, ora como eram quando vivos, ora encantados em animais. Uns deles morreram há bastante tempo, "nos tempos em que as pessoas se encantavam", outros morreram recentemente, mas dizem estar cada vez mais raro encontrar pessoas que tenham o mérito de se encantar após a morte e, mais raro ainda, pessoas que se encantem em vida.

No ano de 2009, morreu uma grande liderança do movimento indígena em Almofala, Raimunda Marques no Nascimento - Raimundinha filha do cacique João Venâncio. Nascida em Almofala, como os demais filhos do cacique, Raimundinha, a mais velha, foi morar em Fortaleza durante a adolescência. Ela, como muitas outras jovens, principalmente da sua geração, foi trabalhar como doméstica na capital do estado, pois em Almofala os empregos são raros. Poucos anos depois, voltou a morar com a família na sua terra natal e começou, por iniciativa própria e voluntariamente, a alfabetizar seus irmãos e vizinhos que se reuniam no terreiro de sua casa para receber as aulas. Mais tarde, os pais das crianças construíram um pequeno galpão de palha que lhes serviu de escola durante muitos anos. Com o tempo, o número de voluntários foi aumentando e as professoras ${ }^{15}$ foram-se articulando com outras instâncias do movimento de professores indígenas. Atualmente, praticamente todas as comunidades têm suas escolas diferenciadas e os professores são pagos pela Secretaria de Educação do Estado, embora os professores sejam, todos eles, contratados em regime temporário, não tendo acesso aos direitos e à

15 Há homens que lecionam, mas a grande maioria dos docentes são mulheres. 
estabilidade conferida aos professores estaduais efetivos. Raimundinha foi vítima de um câncer de útero aos 38 anos, deixando 8 filhos. Sua morte foi um momento de grande comoção no grupo. Sua luta e sua história de vida são lembradas sempre nas reuniões políticas e nas festas das escolas. Poucos dias após sua morte, em uma visita à Escola da Tapera, um professor me contou que, dias após o enterro, ele havia encontrado Raimundinha encantada num pássaro. Desde então, outras pessoas também se referem a ela como uma das raras pessoas que alcançaram o mérito do encantamento. Seu Estêvão, um respeitado ancião, morador da Tapera, contou-me que a viu entre vários dos seus parentes, também encantados, que moram em uma aldeia encantada nas dunas da Tapera. $\mathrm{Na}$ área, há vários sítios arqueológicos que ele próprio ajudou a identificar, pois é ele quem orienta os pesquisadores que chegam à região em relação aos lugares onde se encontram facilmente nas dunas objetos arqueológicos. Seu Estêvão assevera que seus ancestrais já mortos, continuam morando nas mesmas áreas que ocupavam quando vivos, ele conseguia vê-los quando se punha a passear pelas dunas da região, pois ele é uma das raras pessoas que, mesmo não sendo pajé, consegue ver e se comunicar diretamente com os encantados. A grande maioria das pessoas não consegue vê-los, mas, ainda assim, consegue percebê-los de outras maneiras. Infelizmente não pude visitar com ele esses lugares, pois sua idade avançada - mais de 80 anos - e sua saúde frágil impossibilitam as caminhadas pelas dunas.

Há relatos, também, que dizem haver em Almofala vários ancestrais que não chegaram a morrer, mas se tornaram invisíveis ainda em vida. Contam que, na época que chegaram os invasores portugueses, havia humanos que conheciam segredos dos encantes e podiam, ao proferir algumas palavras, tornar-se, eles também, encantados. Tal fato indica que não havia um abismo tão grande, como há hoje, entre humanos e encantados. Atualmente, são raras as pessoas que conhecem palavras que, quando proferidas, tornam-Ihes invisíveis, mas, antes da chegada dos portugueses, esse fato era corriqueiro. Contam que muitos dos Tremembé 
conseguiram defender seus territórios e escapar da morte e da escravidão, pois ficavam invisíveis e os invasores podiam somente ouvi-los, mas não o viam, então perguntavam uns aos outros "E alma fala?!" e acabavam fugindo assustados, por isso o lugar ficou conhecido como Almofala, devido à presença de almas falantes.

A noção de invisibilidade, portanto é inerente ao encantamento. Os corpos dos encantados podem tornarem-se invisíveis e, em dados momentos, voltar a ser visíveis, sem, no entanto, perder a materialidade em nenhuma das situações. Voltarei a este assunto em outro momento.

\section{c) Encantados das matas: Caipora, Guajara e Mãe d'Água}

As pessoas que não veem com bons olhos as práticas rituais ligadas à Umbanda ou quaisquer práticas de incorporação, excluem do rol de encantados os caboclos, deixando somente encantados das matas e alguns ancestrais dos membros do grupo que tenham o mérito, como já foi dito.

São muitos os seres não humanos que habitam as matas e mangues de Almofala, mas três deles estão presentes em todos os depoimentos coletados: o Caipora, o Guajara e as Mães d'Água.

O Caipora é descrito como um morador das matas, embora muitos digam que ele também habita os manguezais. Ainda que muitos os descrevam como tendo a forma de um moleque de mais ou menos 1,30 de altura, com os pés voltados para trás e os cabelos vermelhos, ressaltam que quaisquer encantes têm o dom de tomarem a forma que desejarem, assim, muitas vezes eles aparecem sob a forma de animais, humanos ou qualquer outra aparência.

Os encantados que baixam nos terreiros de Umbanda circulam por várias dimensões, mas, quando estão no nosso mundo, também preferem estar nas matas águas, entretanto, nunca me foram descritos como moradores das matas. Eles passam por vários lugares, mas parecem não fixar morada em nenhum deles. Já os encantados que moram nas 
matas, têm como principais atribuições protegê-las e delas afastar invasores. Ainda que os humanos façam uso cotidianamente dos espaços escolhidos como morada pelos encantados, se eles se sentirem incomodados pela presença humana, podem atuar no sentido de afastá-los dali. Isso nem sempre implica que os "invasores" tenham tido alguma conduta desrespeitosa com os lugares. Dona Inácia, por exemplo, parteira e rezadeira da localidade de Passagem Rasa, me contou que, várias vezes, ao entrar nas matas para colher lenha ou almesca - uma resina de cheiro forte e refrescante que the servia de defumador - sofreu pela ação do Caipora que a deixou ariada, ou seja, fez com que ela se perdesse nos matos. Muitas pessoas me contavam - aos risos, pois costumam divertirse, eles próprios, das travessuras do Caipora - que, mesmo conhecendo tão bem aquela região, muitas vezes viam-se ariados - ou seja, perdidos nos matos, sem saber como voltar para casa, e, assim, permaneciam andando em círculos por muitas horas até encontrarem a casa de algum conhecido ou alguma estrada que as levassem a algum lugar habitado por humanos. Explicaram-me que o ocorrido é obra do Caipora, morador das matas que gosta de se divertir vendo os humanos perdidos, aflitos, procurando as trilhas que eles percorrem todos os dias, mas, de repente, não as reconhecem. Dizem que ele faz isso para "mostrar quem manda" e lembrar aos humanos que, por mais que eles conheçam os caminhos e as propriedades da fauna e da flora local, são eles - os encantados - que conhecem os mais profundos e inatingíveis segredos da natureza. Falarei sobre tais segredos no capítulo seguinte.

O Guajara, também chamado de Pai do Mangue, é um agente que ninguém soube me dizer qual sua "verdadeira" forma, pois ele é muito difícil de ser visto e, quando isso ocorre, ele toma a aparência de um pássaro e, assim, se disfarça em meio à fauna local. Embora poucos o tenham visto, sua presença toma conta dos manguezais de Almofala, lugares protegidos por ele, que sendo invisível, pode vigiar os passos dos humanos sem ser percebido. Sua presença só se torna perceptível, se ele assim o quiser. Nessas ocasiões, ele pode provocar sensações como arrepios ou "um frio 
na barriga" que muitos sentem quando percebem a presença de encantes. Ele pode, também, lançar doenças aos frequentadores dos mangues. Muitos pescadores dizem voltar dos mangues com dores no corpo e na cabeça, provocados por uma pisa do Guajara, como castigo por alguma má conduta em relação àqueles lugares.

Já as Mães d'Água moram nas lagoas de Almofala. Diferente dos outros dois, a quem se referem como sendo entidades únicas (usam sempre o artigo definido para referirem-se a eles: "o" Caipora, "o" Guajara...), as Mães d'Água são várias (para elas, usam um artigo indefinido, diz-se que há "uma" Mãe d'Água em determinada lagoa). São descritas como mulheres de pele clara, com longas cabeleiras - louras ou pretas - que Ihes cobrem os seios desnudos. Muitos dos depoimentos sobre elas, dizem que são vistas nas beiras das lagoas realizando tarefas domésticas, como lavando louças ou roupas ou, simplesmente, banhando-se. São de uma beleza tão estonteante que levam ao delírio muitos dos homens que as veem e ficam completamente enfeitiçados por seu encanto, a ponto de serem levados com elas para "o outro lado" sem oferecer qualquer resistência. Estas situações, contudo, são muito raras. No geral, os encontros com as Mães d'Água, assim como com os outros, são furtivos, ao menor sinal da presença humana, elas mergulham nas lagoas e somem, sem deixar quaisquer vestígios. Os humanos, por sua vez, também estão sempre a fugir desses encontros, por saber dos riscos a eles inerentes.

\section{d) Outros Personagens}

Além de caboclos da Umbanda e os moradores das matas, várias outras entidades são citadas nas conversas com os Tremembé. Seria impossível aqui dar conta de todas, mesmo porque elas surgem a todo instante, já que seus mundos, como os nossos, estão num constante devir.

Alguns personagens muito comuns nas narrativas são fadas e personalidades da realeza que se encantaram "nos outros tempos", quando ainda existiam reis e rainhas no Brasil, e, desde então, vivem em enormes 
reinados invisíveis nas praias e matas de Almofala. Em

algumas narrativas, eles são caracterizados como caboclos, pois alguns dos personagens que baixam nos trabalhos se apresentam como reis ou princesas, como o Príncipe Rafael, o Rei Salomão ou a Princesa do Pensamento. As narrativas de Dona Maria Bela, em especial, citavam vários reis, príncipes, princesas e fadas que baixavam na sua coroa ou se apresentavam a ela em meio às suas caminhadas na região. Tais personagens nem sempre se apresentam sob a forma de humanos, alguns deles, como o Reis Tubarão, são personagens da realeza que se encantaram em animais.

Em muitas das conversas com Dona Maria Lídia, rezadeira e liderança do Panã, ela tentava me fazer compreender como eram e o que faziam os encantados. Ela dizia que "antigamente tinha muita fada e as fada se engraçavam deles, do príncipe ou da princesa, aí encantava eles". Ela explica que hoje, a grande maioria das pessoas desconhece a existência de encantados e conta suas histórias como se fossem brincadeiras ou fantasias para embalar os sonhos das crianças $^{16}$. Mal sabem que, longe de serem uma mera fantasia, são histórias que de fato aconteceram, mas há tanto tempo que foram esquecidas pelas gerações atuais. Nos tempos em que todas as coisas eram encantadas e não havia separação entre "o nosso mundo" e "o dos encantados". Ninguém sabe, evidentemente, precisar quando se rompeu esta ligação, o que muitos dizem é que antes da chegada dos europeus, os índios velhos sabiam os segredos dos encantes, pois tinham merecimento para tanto.

Esses são, grosso modo, as descrições de encantados que pude identificar em campo. Tratam-se, portanto, de múltiplas entidades com diferentes modos de agir, que tanto atuam para assustar ou lançar doenças

\footnotetext{
16 Ver o Anexo XX, no qual ela conta a história de um príncipe que fora encantado na
} forma de um camaleão e lutava para livrar-se do encantamento. 
aos humanos, como para auxiliar os membros do grupo a protegerem os lugares que elegem como morada. Entretanto, há também vários outros tipos de encantamento, os quais serão mencionados nos próximos capítulos, quando falarei das disputas entre humanos e encantados pelas áreas de Almofala e como estes se relacionam nessas disputas. Destaco, todavia, que não pretendo aqui dar conta de todas essas formas de agências, coisa que seria impossível, pois novos encantes podem surgir todos os dias, bem como mudarem de lugar e levar ou trazer consigo objetos que compõem as paisagens.

Diante do exposto até então, podemos observar que os encantados se manifestam em basicamente três situações: para curar enfermos, nos rituais de cura; nos eventos políticos, onde são invocados para ajudar as lideranças na luta pela garantis de seus direitos políticos e, por fim, em encontros ocorridos nos lugares que nós classificaríamos como "natureza". No primeiro caso, as práticas de cura envolvem diferentes rituais praticados por diversos tipos de curadores. Em alguns rituais, as entidades se incorporam em pajés para, através deles, praticarem a cura; em outros, são invocados pelos rezadores ou rezadeiras através de rezas palavras que guardam, na maioria dos casos, em segredo e que têm o poder de contatar os encantados e, mesmo não havendo incorporação, conseguirem a cura. Já quando aparecem fora dos rituais, os encontros se dão, em geral, nas matas e águas e têm várias motivações: ora eles assustam os humanos, no intuito de afastá-los das suas moradas; ora atuam no sentido de guiarem aqueles que estão perdidos nas matas; ora, ao contrário, os deixam ariados; ora não chegam a aparecer, mas dão sinais e fazem revelações sobre as propriedades curativas da flora local... Outrossim, manifestam-se através de sonhos ou outras revelações.

Na sequência, farei algumas descrições sobre os rituais nos quais encantados são invocados para praticar a cura, por ora, todavia, passemos às descrições sobre entes não humanos que não são caracterizados pelos Tremembé como sendo encantados. 


\subsubsection{Assombrações ou Visagens}

Além dos encantados há também os espíritos dos mortos. Os destinos dos vivos após a morte podem ser vários. Uns passam para "outro mundo" de onde não podem voltar, outros se encantam e podem circular livremente entre os vivos e os mortos e há ainda alguns que se põem a vagar sem rumo pelo mundo e podem chegar a atrapalhar a vida das pessoas, estes são chamados de encostos ou sombras. Nos depoimentos que coletei sobre estes últimos, foi-me esclarecido que nem sempre eles atuam "por maldade", às vezes querem só chamar atenção de algum humano para que este resolva algo que não está mais ao seu alcance. Um bom exemplo, foi-me contado pelo pajé Luís Caboclo, por ocasião de uma farinhada ${ }^{17}$ que ocorria nas proximidades da sua casa. $O$ pajé foi chamado à casa de farinha para socorrer uma moça que havia sido "possuída por um espírito". Lá chegando, encontrou a moça sem consciência, com o corpo enrijecido e os olhos revirados, cena que assustava todos à sua volta. Ele então a segurou pela mão e pôs-se a conversar calmamente com o espírito que a possuía, tentando convencê-lo a sair dali e não atormentá-la mais. O espírito esclareceu, de sua parte, que não tinha intenção de fazer mal algum aos presentes nem à moça e, se havia se encostado nela, era porque andava a vagar pelo mangue e a encontrou por lá, assim, como simpatizou com ela, resolveu nela se encostar na esperança de que ela pudesse resolver um problema que ele havia deixado pendente quando ainda estava vivo: ele não havia sido batizado, por isso, não alcançou uma existência tranquila após sua morte. Rapidamente, então, o pajé realizou um ritual de batismo e o espírito foi embora e pôde, enfim, desprender-se do "mundo dos vivos". Vários outros casos semelhantes foram-me relatados, alguns espíritos pediam uma missa, pois suas famílias não haviam cumprido

17 ritual no qual a mandioca é transformada em alimento. 
corretamente os ritos ligados à morte, que envolvem missas e rezas, outros pedem apenas uma oração, que pode ser um Pai Nosso ou uma Ave-Maria...

Há também aqueles que deixaram dívidas em dinheiro. Caso o morto tenha alguma dívida, por menor que seja, sua alma não consegue ter paz até que consiga saudar o débito. Com este fim, o espírito tenta dar avisos aos seus para que paguem aquilo que ele devia em vida e começa a fazer aparições, algumas delas em sonhos. Após quitadas as suas pendências, ele segue ao "mundo dos mortos".

Do mesmo modo, as pessoas que morrem tendo deixado dinheiro escondido também não conquistam uma existência tranquila no pós-morte. Contam-se muitas histórias de verdadeiros tesouros que foram revelados através de sonhos. São as botijas. Dona Neném Beata e sua filha, Ângela, explicaram-me durante uma de nossas longas conversas na cozinha de sua casa que as botijas só podem ser entregues pelo próprio morto que aparece em sonho para revelar o local exato onde deixou suas riquezas. É possível identificar locais onde elas estão enterradas porque neles costuma aparecer um fogo que se mostra nas noites escuras por sobre o local onde as botijas estão enterradas, fazendo-se ver por muitas pessoas. É a alma dos avarentos que se transforma em fogo, após a morte. Diferente de muitos encantes que só podem ser vistos por aqueles que têm o dom, o fogo das botijas - chamado de fogo fato - pode ser visto por praticamente todos. Contudo, se aquele que o vê tenta resgatar o tesouro, pode sofrer graves consequências, pois ele só pode ser resgatado com a anuência do morto que o enterrou. Todavia, ainda que os mortos apareçam em sonho para dar seus bens, os resgates destes não é tarefa fácil. As almas daqueles que, por ambição, deixam dinheiro, joias ou quaisquer outras riquezas escondidas são amaldiçoadas e ficam presas pelo demônio, só podendo ser libertadas após resgatados os tesouros. Por isso, para perpetuar o domínio sobre as almas, o demônio aparece para proteger os tesouros e impedir o resgate, assustando as pessoas que se lançam a tal aventura. Conforme me explicaram Dona Neném e sua filha: 
Dona Neném: Onde fica ouro enterrado, tem que aparecer o fogo, por causa que ele se encanta, sabe? O ouro, ele se encanta e o dinheiro em moeda também se encanta, mas só depois que a pessoa morre, depois que a pessoa morre, se deixar dinheiro enterrado, aí se encanta. (...) Só pode arrancar [a botija de dentro da terra] se a alma que enterrou vier dar...

Ângela: É! Tem que sonhar três vezes e não contar pra ninguém. A minha irmã sonhou com uma ali perto da praia. Os morro tudo branco e ela viu, ela sonhou... Quando foi no outro dia, amanheceu dizendo que a mulher tinha vindo dar uma botija a ela, quando foi no outro dia, cadê que ela sonhou mais? Não pode! Disse [a mulher que veio dar a botija] que ela fosse seis da manhã ou seis da noite. (...) Juliana, aqui em cima desses morro tem tanta botija! tanta botija! Lá naquela casinha que nós morava lá do outro lado, não era, mãe?... Não sei se tu chegou a conhecer uma casinha que nós morava lá do outro lado... Quando foi um dia a mamãe "minha fia, vem cá! Um fogo!" Quando eu vi, eu "mamãe é uma alma!" (risos) e ela "é não, é botija! quase todo dia eu vejo esse fogo aí, é botija!". Dona Neném: Hum hum, ela saía lá na cabeça do morro e saía rolando morro abaixo, flutuando, tão bonito!... (...) Mas eu nunca fui buscar não, que eu tinha medo!

Juliana: E a senhora já sonhou?

Dona Neném: [balançando a cabeça afirmativamente] Hum hum. A alma disse assim, vá buscar que o caixão, de tanto os animais pisarem em cima já tá com as beirada tudo ralada...

Ângela: disse que a gente tem que levar tudo! Imagem de santo, vela, água benta, tudo o que a gente tiver, porque aparece tudo no mundo! Astúcia do bicho véi [o demônio] que não quer que a gente tire, né?

Dona Neném: E por isso eu não fui...

Ângela: a minha sogra, Juliana, ela era muito assim [faz um gesto com a mão fechada, sinalizando que a sogra seria avarenta], aí sabe o quê que ela fazia? Ela enterrava dinheiro. Aí parece que ela botou debaixo dos tijolos da casinha véa. Aí, quando ela morreu, ela foi dar prum menino, sobrinho dela, primo do meu marido. (...) Ela explicou bem direitinho onde tava, no outro dia, ele partiu, foi buscar. Chegou lá, procurou, procurou e não achou nada, sabe por quê? Porque foi com ambição! Se você tiver ambição de pegar esse dinheiro, você não arruma nada, não acha nada...

Juliana: e se a pessoa resgatar o dinheiro, a alma se salva?

Dona Neném: só pode é se salvar, né, porque tira o fogo... o fogo não aparece mais... Se ela tem merecimento de vir dizer onde tá, é pra pedir alívio pra alma dela... (...) A pessoa que vai tirar, disse q vê tudo, aparece de um tudo, o bicho véi se vira numa cabra, se vira num cachorro, tudo aparece... pra assombrar aquela pessoa, pra pessoa não tirar...

\section{Esta conversa dá algumas pistas das relações estabelecidas}

entre vários entes não humanos entre si. O ouro se transforma em encante

- a botija - porém o encantamento não se estende à alma, que não se torna encantada, mas fica presa nesse mundo, sob domínio do demônio. A salvação da alma depende do desencantamento do objeto, assim o resgate 
da botija torna-se um palco de luta que envolve humanos, assombrações, encantados e o demônio.

Há também espíritos que estão na terra para se vingar de alguém ou perturbar aqueles de quem não gostavam em vida. Estes costumam resistir a deixar o "mundo dos vivos" e parar de causar perturbações, então é necessário recorrer aos rituais de Umbanda. Nos casos mais sérios, é preciso uma série de três ou nove rituais para conseguir afastá-los, mas nunca ouvi relato algum em que não fosse possível afastá-los, ainda que eles insistam em ficar entre os vivos, acabam por seguir seus caminhos, pois, só conseguem permanecer entre "no nosso mundo" após a morte, aqueles que têm um merecimento para tanto - os encantados.

Outro tipo de mal-assombro consiste em um choro que passa a ser ouvido à noite ou de madrugada, geralmente em áreas de encruzilhada. Quando isso ocorre, as pessoas já sabem do que se trata: são os anjinhos ${ }^{18}$ que morreram ainda pagãos - ou seja, antes do batismo - e que, exatamente por serem pagãos, não têm direito a um enterro cristão, no cemitério, e são, por isso, enterrados nas encruzilhadas. Inconformados, os bebês choram à noite, à espera de alguém com coragem para procurá-los, guiado pelo som do choro, e realizar o batismo. Nunca presenciei esta cena, mas as pessoas que já encontraram um choro de bebê na noite, dizem que é necessário somente fazer uma reza na encruzilhada onde se escuta o som do choro e, assim, o bebê pára de chorar na mesma hora, sinalizando que a reza funcionou, agora ele está batizado e pode seguir em paz para o "mundo dos mortos".

Mas choros de bebês - e, às vezes, até mesmo de adultos - não são os únicos sons que vêm das matas e que assombram os moradores de Almofala. Um dos sinais mais evidentes da presença de encantados se faz pelos sons. Seu Zé Domingos - importante interlocutor de quem falarei mais adiante - me repetia inúmeras vezes que "encantado é aquilo que a gente escuta, mas não vê". Ele menciona vários sons que ecoavam das matas,

${ }^{18}$ Como se chamam aqueles que morrem ainda bebês, sejam eles batizados ou não. 
mas que não deixavam vestígios materiais de nenhum acontecimento. Sons de árvores tombando, galhos quebrando... barulhos ensurdecedores que, se fazem ouvir por várias pessoas, mas não deixam nenhum vestígio visual. São sons que os encantados produzem simplesmente para assustar e afastar as pessoas de suas moradas.

Um desses sons que constitui um péssimo agouro para quem os ouve é o assobieiro, uma entidade que ninguém sabe se tem de fato um corpo, pois nunca foi vista. Só se ouve o assobio que se propaga nas matas e entra nas casas em meio às noites escuras e madrugadas, amedrontando aqueles que escutam e já sabem que este é um sinal para que permaneçam em suas casas.

Registrei também várias menções a pessoas que, mesmo não sendo encantadas, têm seus corpos transmutados em outra coisa, pois portam um tipo de maldição que as transforma em feras. São os lobisomens que, especialmente em noite de lua, transmutam-se e saem pelas matas em busca de vítimas.

Enfim, as descrições sobre as assombrações que se manifestam nas matas de Almofala são incontáveis. Sons, encontros, sensações que se podem apresentar sob quaisquer formas, já me foi falado de moleques que corriam, faziam estripulias e cambalhotas pelas pequenas trilhas de terra entre as matas, de pernas que andavam sozinhas, separadas de seus corpos... Todas elas, independente das descrições, revelam perigo e põem aqueles que as presenciam em estado de alerta, pois, diferente dos seres encantados aqui já descritos, as assombrações podem ser entidades malignas capazes de prejudicar severamente alguém com que se depare em meio às matas.

Ressalto, todavia, que esta classificação que proponho aqui não é consensual entre os membros do grupo. Uns também classificam as assombrações como encantados, já que todos estes seres fazem parte "do mesmo reino" - o reino dos encante -, outros, como já destaquei, excluem da categoria encantados os caboclos da Umbanda. Alguns descrevem os encantados como seres que só existem para trazer benesses a esse mundo, 
outros dizem haver encantados bons e maus - de um lado os que curam e, de outro, os que jogam feitiços, assombram ou mesmo matam... Enfim, se proponho aqui uma possível diferenciação entre todos eles, é para facilitar a análise das manifestações, atribuições e agências de cada um deles no decorrer deste trabalho.

\subsection{Trajetória em campo: conhecendo os Tremembé e seus mundos encantados}

Como é possível constatar pelo exposto até então, as relações estabelecidas entre os humanos e cada uma dessas entidades obedecem a uma série de especificidades, por isso achei fundamental começar por caracterizar esses personagens, todavia, é preciso também caracterizar os diferentes momentos em que elas se manifestam.

É o que farei na sequência, ao descrever minha experiência em campo e como fui-me deparando com as situações e os depoimentos que envolviam manifestações de seres não humanos.

Cumpre esclarecer, antes de tudo que, como todo esforço etnográfico, esta é uma tarefa árdua, um trabalho, muitas vezes, confuso, onde o exercício antropológico coloca-nos diante do desafio de "traduzir" os diferentes universos de ação e significação com os quais nos deparamos em campo lançando mão, entretanto, das referências da nossa própria cultura. Para Wagner (2012), não podemos simplesmente "aprender" uma outra cultura como algo objetivo, devemos, isto sim, "assumir" as diferentes culturas como ferramentas de transformação do nosso próprio universo. Ou seja, ao "inventar" a cultura do outro, estamos, também, inventando nossa própria cultura e nos reinventando. A etnografia não é um mero esforço descritivo da situação de campo ou, em outras palavras, uma forma de descrever aquilo que aprendemos sobre o outro de modo objetivo, mas é o produto de uma relação entre pesquisador e pesquisado. A ideia de que precisamos, para um bom empreendimento etnográfico, "virar nativos" é improdutiva para o nosso ofício, pois nos obrigaria a abrir 
mão dos nossos próprios padrões culturais. O que etnografamos é, muito mais, uma "invenção" daquilo que apreendemos da cultura do outro a partir do choque com as nossas próprias percepções sobre o mundo. Assim, um bom trabalho etnográfico deve começar por reconhecer que o que chamamos de "cultura" é fruto da relação cotidiana entre antropólogo e nativo, daquilo que um consegue compreender do outro. Contudo, precisamos considerar que o que percebemos como "cultura" no outro nem sempre é a mesma coisa que ele procura em nós. Em outras palavras, o que a sociedade ocidental compreende como cultura - como algo oposto ao que é dado (a natureza) - pode não ser o que os nativos compreendem. Destarte, para compreendermos as formas de percepção dos nativos precisamos superar essa dualidade.

Mesmo diante da multiplicidade de descrições de como eram os encantados que se apresentavam numa proliferação de variedades de formas de ser e de se manifestar, com o tempo, à medida em que eu ia analisando depoimentos, histórias de vida e o cotidiano de pessoas com as mais diferentes trajetórias de vida, fui conseguindo compreender alguns elementos que perpassavam todas as narrativas. Embora estes seres se manifestem de formas bem diferentes, todos escolhem lugares parecidos como morada e têm o poder de controlar fenômenos que a sociedade ocidental classifica como "naturais" e, muitas vezes, mais do que seres "personificados" que controlam os fenômenos "naturais", eles constituem os próprios fenômenos. Em muitas narrativas as plantas curativas, as matas, as águas são apresentadas como coisas que têm encante. São, portanto, objetos plenos de agência. Por este motivo, evito aqui reduzir os encantados a um conjunto de seres que agem sobre um mundo. Não são seres encantados que controlam os fenômenos e as coisas deste mundo. $O$ que os Tremembé me mostraram foram mundos encantados - plenos de entidades, coisas e fenômenos encantados.

Isto posto, pretendo, a partir de então, expor alguns dados etnográficos através dos quais penso ser possível compreender quais 
elementos entram em jogo quando os Tremembé mobilizam a categoria de encantados.

O tema dos encantados é muito frequente nas conversas com os Tremembé, por isso ele é mencionado por praticamente todos os pesquisadores que já passaram por Almofala. Uma forte característica do grupo, também frequentemente apontada nos trabalhos já realizados com eles é o fato de que as pessoas são extremamente acolhedoras. É fácil "movimentar-se" em campo porque praticamente todos estão dispostos a ajudar, em quase todas as casas onde eu chegava, era-me oferecida uma rede no alpendre, uma comida - geralmente a tapioca - e uma bebida, fosse café, água de coco ou, no período de safra do caju, o mocororó, tradicional vinho preparado, em geral pelas mulheres, pela fermentação do caju azedo. Os moradores de Almofala já foram foco de muitos trabalhos em áreas diversas, como antropologia, sociologia e, nos anos 50 , de folcloristas interessados na dança do torém, tomada nesses trabalhos como um dos últimos vestígios dos "antigos" índios que habitavam a área. Até o início dos anos 90, os membros do grupo eram tratados como "descendentes" ou "remanescentes" de índios. Após o processo de organização política em torno do reconhecimento diante do Estado, passaram a ser objeto de interesse da Antropologia, na época, às voltas com o tema do "ressurgimentos" de comunidades indígenas em regiões "inusitadas" do país, como é o caso do Nordeste, onde, há muito, a história oficial postulava a inexistência de grupos indígenas.

O fato é que a presença de pesquisadores entre os Tremembé não é novidade para eles. Quando eu era apresentada como "pesquisadora" e, mais ainda, que realizava uma pesquisa sobre os encantados, não faltava assunto, mesmo aqueles que afirmavam nunca haver tido contato algum com "seres de outro mundo", como também se referem aos não humanos, sempre sabiam de alguma história ou podiam me indicar alguém que tivesse muito a falar sobre o assunto - as pessoas indicadas como as que melhor conheciam os encantados eram os agricultores e pescadores mais velhos, rezadeiras ou pajés. No geral, as reações eram muito bem- 
humoradas. As conversas, frequentemente, começavam com casos engraçados de pessoas que haviam sido enganadas ou assustadas por encantados que habitam as matas ou águas da região, muitos, inclusive, chegavam a me perguntar com admiração se eu não tinha medo de estar "mexendo com essas coisas", ir aos trabalhos ${ }^{19}$, frequentar certos lugares... Frequentemente me alertavam sobre o perigo de entrar em contato direto com um encantado, sob o risco de "passar para o outro lado".

Como veremos, estas formas de encantes permeiam vários âmbitos da vida social do grupo, assim, sobre os mais diferentes assuntos, quase sempre, em algum momento, contar-se-ão histórias sobre eles. Mas, especialmente, se a conversa gira em torno das transformações espaciais ocorridas nos últimos anos, impreterivelmente, acaba por abordar o risco que os lugares correm de ficar "sem a proteção" dos encantados, pois estes, estando sem lugar onde morar, estão gradativamente se mudando de Almofala para outros lugares onde há natureza onde eles possam pousar. Estas discussões têm-se intensificado nos últimos anos, devido ao agravamento da situação de devastação ambiental que o grupo vem atravessando.

Mas não foram os depoimentos sobre os problemas ambientais que me levaram ao tema dos encantados. Nas minhas primeiras visitas aos Tremembé, iniciadas em outubro de 2002, foram as narrativas sobre as práticas rituais de algumas pajés que me apresentaram este universo.

Conheci a Área Indígena, através de um professor da Universidade Estadual da Bahia, Marcos Messeder, que, no momento, era doutorando na Universidade de Lyon, onde desenvolvia uma pesquisa, posteriormente consolidada na tese Les Rituels et Drames d'Alcoolisation chez les Tremembé. O cerne da pesquisa era o consumo do álcool entre os Tremembé e minha contribuição seria acompanhar tal consumo entre as mulheres. A presença de uma pesquisadora seria importante porque as mulheres bebiam muito reservadamente e, procuravam fazê-lo entre si, se

${ }^{19}$ Refiro-me aqui aos rituais que envolvem incorporação. 
possível, sem a presença de homens por perto. Isto porque, segundo elas, não queriam ser alvo de fofocas lançadas às mulheres que consomem álcool ou quaisquer outras "drogas".

$\mathrm{Na}$ época, eu e Messeder passamos três meses em campo, intercalados com viagens frequentes a Fortaleza para sistematização dos dados. Nas primeiras semanas de campo, eu o acompanhava nas suas atividades e, através dele, fui conhecendo várias famílias do grupo, principalmente aquelas pessoas que tinham um envolvimento direto com as o movimento indígena - as "lideranças", como se autointitulam os membros mais participativos nas atividades políticas. Com o tempo, fui fazendo contatos e começando a participar da vida social do grupo com mais autonomia. Assim que chegamos, ficamos hospedados na casa do Cacique que na época morava só com uma filha adolescente. Todos fazíamos as refeições na casa da Dijé - irmã do cacique e agente de saúde indígena. Assim, não demorou muito para que eu fosse criando intimidade com a Dijé, que estava grávida da sua filha caçula, e toda a sua família, na ocasião, o marido, três filhos adolescentes e duas crianças. Todos se mostravam muito acolhedores e curiosos com a nossa presença ali, sobretudo as crianças, Silene e Quitéria, com aproximadamente seis e três anos, respectivamente. As duas tornaram-se minhas principais companheiras pelas andanças na Praia de Almofala. No começo do campo - e ainda hoje - os caminhos por entre as dunas, manguezais e matas de Almofala me deixavam totalmente desnorteada, então a ajuda das meninas era fundamental para eu me locomover, além disso, nossas conversas eram muito preciosas à pesquisa, pois elas estavam sempre atentas ao meu interesse em conhecer pessoas, comidas, plantas, enfim... Todas essas "curiosidades" do ofício antropológico que, por vezes, acabam por impacientar os adultos, nas crianças, ao contrário, provocam interesse. As duas estavam, portanto, sempre prontas para me apresentar pessoas, falar dos trabalhos das pajés ou dos caminhos mal-assombrados pelos quais passávamos, em especial quando já caía a noite. Aliás, nas noites "sem lua" a companhia delas se fazia ainda mais fundamental, pois, enquanto os 
nativos se locomoviam com extrema agilidade na escuridão daqueles caminhos, na época, ainda sem luz elétrica, para mim, este feito parecia impossível!

Por várias razões, a casa da Dijé foi ponto de apoio de muitos pesquisadores que passaram pela área. Quando a conheci, era uma pequena casa de taipa e palha, situada em frente à Escola Maria Venância, a primeira escola diferenciada da Área que funcionava, então, em um pequeno galpão de palha, construído pelos próprios moradores. Entre as duas construções havia uma área circular, onde se dançavam o torém em dias festivos. Ou seja, sua casa ficava situada no "centro" da aldeia. Praticamente todos que chegavam passavam primeiro por lá para pedir quaisquer informações, destarte, quem não tinha um destino preestabelecido antes de chegar na área, acabava ficando por lá mesmo.

Mas esses não eram os únicos motivos que faziam da sua casa uma "parada obrigatória" pelos pesquisadores e curiosos. Sua família era referência para os pesquisadores da região já desde bem antes do processo de organização política pela reivindicação de reconhecimento étnico. No início desse processo, a dança do torém foi o principal elemento de diferenciação elencado no discurso indígena como símbolo de uma origem étnica comum do grupo. Bem antes disso, entretanto, ainda nos anos 40, o folclorista Florival Serraine permaneceu durante alguns dias em Almofala no intuito de documentar a dança do torém, que descreveu como sendo uma dança praticada por alguns moradores da Lagoa Seca ${ }^{20}$, liderados pelo velho José Miguel que era auxiliado por sua irmã, Francisca Ferreira de Paula, conhecida como "Tia Chica". Ambos permaneciam no centro da roda, cantando as cantigas do torém e cercados pelos demais que dançavam ao som do maracá de Seu José Miguel, girando no sentido solar, mas, vez por outra, mudando subitamente de direção. Já nos anos 60, outro pesquisador, Silva Novo, também visitou Almofala interessado no torém. Ambos os pesquisadores tratam o grupo por eles pesquisado como sendo

${ }^{20}$ Esta é uma importante localidade para a comunidade, mas ficou fora da área demarcada porque, na época em que foi realizado o estudo, era foco de muitas disputas. 
de "descendentes" dos "antigos tremembés" que habitavam a área. Entretanto, apesar da visão assimilacionista que nutrem, em várias partes de ambos os textos, eles afirmam haver "índios puros" entre os membros do grupo, que teimavam em resistir, apesar dos severo processo de aculturação ao qual estavam imersos. Silva Novo, em sua pesquisa realizada em 1965, descreve Tia Chica da Lagoa Seca como sendo "uma índia pura, sem mistura de sangue civilizado" (1976, p.22).

Orientados pelas descrições sobre o torém, muitos pesquisadores que visitavam a área, procuravam as famílias dos "antigos torenzeiros" na busca de informações sobre a história do grupo. Assim, a família da Tia Chica, bisavó do atual cacique e de sua irmã, Dijé, era frequentemente procurada para dar depoimentos sobre o torém. Além de puxaderia de torém, Tia Chica se destacava entre o grupo por várias outras habilidades, constituindo uma grande referência para os moradores do lugar. Ela rezava ${ }^{21}$, dava conselhos, era chamada para resolver conflitos entre vizinhos e familiares... Atualmente, seu neto, João Venâncio - é o principal puxador de torém de Almofala e ocupa o cargo de cacique desde os anos 90. Ou seja, trata-se de uma família que está sempre em evidência, que sempre é procurada pelos que visitam a área, mesmo porque, além da ancestralidade, João Venâncio e Dijé foram - e ainda são - figuras muito importantes no processo de organização política do grupo.

Portanto, como era de praxe aos que passavam por ali, eu e Messeder sentamos pouso nas casas dessa família. Uma estratégia elaborada por nós para que eu adentrasse nesse universo do consumo do álcool entre as mulheres foi que eu começasse a acompanhar a Dijé no seu trabalho como agente de saúde. O número de agentes de saúde em 2002 era bem reduzido em relação ao que é hoje, então ela era responsável por toda a área da Praia, que abrangia várias comunidades. Assim, passei a visitar várias casas quase todos os dias, conhecendo várias pessoas, ouvindo suas histórias... Quando eu explicava que estava ali para entender

21 Diz-se de quem pratica cura através de rezas, sem todavia, envolver rituais de incorporação. Ainda neste capítulo, falarei mais sobre o assunto. 
a forma como as mulheres faziam uso do álcool, isso era motivo de muitas risadas, pois, ainda que os Tremembé estejam "acostumados" com a presença de pesquisadores na área, o trabalho dos antropólogos ainda é visto como sendo algo um tanto esdrúxulo, já que é difícil compreender como elementos tão simples e essenciais dos seus cotidianos possam causar tanto interesse. Ainda assim, eu passei a ser constantemente convidada para ocasiões onde haveria o consumo do álcool, fossem festas, casamentos, batizados, ou, simplesmente, reuniões mais íntimas, nas suas casas, onde podíamos beber e conversar mais livremente.

A oportunidade de acompanhar o exercício transgressor do beber entre as mulheres possibilitou o estabelecimento de certa cumplicidade entre nós, o que facilitou bastante minha relação com o grupo. Havia muitos momentos de festa e descontração, mas também momentos angustiantes, quando trocávamos confissões reveladas pela embriaguez. Um tema recorrente nas nossas conversas eram os problemas relacionados ao uso do álcool. Tanto nos momentos em que saíamos para beber, como nas visitas domiciliares era comum, ao conversarem sobre o assunto, as mulheres afirmarem que o uso excessivo do álcool se devia à ação de entidades que, por diversos motivos, incitavam as pessoas ao consumo exagerado de bebidas alcoólicas. Essas entidades eram espíritos malignos, almas perdidas ou encantados, cada uma delas tinha uma razão diferente para perturbar a vida dessas pessoas. Espíritos malignos e almas, quando o faziam, tinham - como expliquei ao descrevê-los anteriormente - o intuito de vigar-se de alguma questão deixada em vida ou para revolver outras pendências, tais como dívidas, rezas ou batismos. Já os encantados, embaraçam a vida das pessoas para pressionar-Ihes a praticar rituais de incorporação que permitiriam às entidades nelas se incorporarem para praticar a cura e trazer outras benesses a esse mundo. Quando as pessoas revolvem atender ao chamado dos encantados, buscam desenvolver o dom de incorporá-los e começam a trabalhar, ou seja, realizar rituais de incorporação. Tais rituais são chamados de trabalhos de mesa, tundá, entre vários outros termos, mas, na maioria dos casos, são classificados como 
trabalhos de Umbanda e as pessoas recorrem a eles em busca de soluções para os mais diversos problemas, tais como doenças dos filhos, querelas conjugais ou financeiras. Mas a maioria delas diziam recorrer a tais práticas quando eram surpreendidas por fenômenos que consistiam em ver ou ouvir seres encantados. Estes eram sinais de que os suas correntes estavam arriando, ou seja, os encantados as estavam chamando para o trabalho, pois eles precisam se incorporar em algum humano para, através deste, praticar a cura aos que deles necessitam. Por isso, escolhem algumas pessoas do grupo e, de tempos em tempos, se revelam a elas, dando início a um jogo de poder no qual o objetivo é fazê-las desenvolver o dom de incorporá-los e, desta maneira, alcançar a possibilidade de estabelecer uma comunicação direta com os humanos que não têm o dom de vê-los. Nesse jogo, a atuação de pessoas já desenvolvidas - pajés - é fundamental, pois só assim é possível acalmar os encantados e conseguir livrar-se dos tormentos. Quando espíritos malfazejos se aproveitam de eventuais momentos de fragilidade das pessoas e incorporam-se ou encostam nelas, é preciso, também, recorrer às práticas rituais de pajés.

Aqui julgo necessário fazer uma rápida digressão para falar do uso do termo "pajé" que, neste momento da pesquisa, me chamou muita atenção. Foi difícil para mim perceber os diferentes usos desta categoria e explico o porquê. Logo nos primeiros dias de campo, conheci o Pajé Luís Caboclo, que me foi apresentado como "o pajé Tremembé" que tinha por função representar o grupo, ao lado do cacique, frente ao movimento indígena. No entanto, ao conversar sobre os trabalhos de encantados, muitos dos meus interlocutores referiam-se às pessoas que os praticavam também pelo termo "pajé", ao que eu retrucava: "Há, então, outros pajés no grupo, além de Luís Caboclo?" Ao que me era prontamente respondido: "Não, nosso pajé é o Luís Caboclo, os outros são pajés de trabalho". Seu Luís foi escolhido pajé na mesma época em que João Venâncio foi eleito cacique. Sua escolha se deveu ao fato de ele ser uma importante liderança 
política e um rezador respaldado pelos membros do grupo ${ }^{22}$. Seu cargo, portanto, é um cargo político e sua função é representar o grupo frente ao Movimento Indígena, um movimento da sociedade civil por reivindicações de políticas públicas específicas para a população indígena, como saúde e educação diferenciadas e, sobretudo, a demarcação das terras.

Entretanto, como a pesquisa de campo foi-me revalando, há vários outros pajés no grupo, pois o termo também é usado para referir-se àqueles que praticam a cura através de rezas ou incorporações. Esses últimos - embora sejam pessoas muito reverenciadas pelos membros do grupo - não costumam participar das atividades políticas, ainda que muitos deles se identifiquem como índios e defendam, diante dos demais membros do grupo, as reivindicações políticas pleiteadas por todos, não são vistos com frequência nas assembleias ou outras reuniões políticas. Nas assembleias, por exemplo, é de praxe uma mesa sobre as práticas de cura para as quais são convidados vários pajés. Na primeira Assembleia Tremembé, em 2009, havia uma mesa a ser composta por várias pajés e rezadeiras da região da Praia, que foram convidadas para falar de suas experiências para o grupo e, em seguida, participar de um debate sobre o assunto, porém, no momento das apresentações, as convidadas não compareceram e a mesa, esvaziada, contou com a presença apenas do Pajé Luís Caboclo, que já têm o hábito de participar destas atividades. Pude presenciar cenas parecidas também em outras assembleias que pude assistir durante a pesquisa de doutorado. Ou seja, há uma recusa da maioria dos pajés em participar como "lideranças" das atividades políticas. Isso não significa, entretanto, que suas atividades não sejam politizadas, já que todos os pajés que conheci manifestam interesse e preocupação com as questões políticas, especialmente a demarcação das terras e a degradação ambiental, já que os encantados precisam desses lugares para pousar morada no "mundo terreno". Além disso, muitas vezes foi-me ressaltado que para enfrentar as agruras inerentes ao Movimento Indígena

22 Os rituais de reza, todavia, não envolvem incorporação. 
é preciso estar com o espírito forte. Para tanto deve-se, sempre que possível, recorrer a rezas e rituais de limpeza para afastar os maus espíritos que atuam no sentido de atrapalhar os índios e atravancar suas conquistas. Ou seja, não se trata de um trabalho político, no sentido que nós entendemos - como relações de poder entre humanos - mas de uma cosmopolítica23, já que envolvem as relações entre mundos e subjetividades distintas.

Os trabalhos dos pajés costumam ser eficazes quando se tratam de curar doenças, reatar amores e outras coisas mais, entretanto, os tormentos causados àqueles que se recusam a trabalhar só cessam se tais "escolhidos" aceitarem desenvolver o dom e passarem a receber os encantados e praticar curas. Caso esta dádiva não seja aceita, as entidades sempre retornam, assim, de tempos em tempos, é necessários recorrer a algum pajé para suspender as correntes, trabalho cujo objetivo é abrir uma trégua no elo com entidades sobrenaturais.

A passagem do "outro mundo" - que as ontologias naturalistas classificariam como sendo um mundo "sobrenatural" - ao mundo dos vivos se efetiva através das correntes. Elas se subdividem em várias linhas, numa pluralidade de descrições, cores e definições muito variadas. Entidades que vêm a esse mundo para "fazer o bem" chegam através das linhas ou correntes brancas. Já os seres malévolos, chegam pela linha preta.

Quando entrevistei algumas entidades no trabalho de Seu Chico Brega, explicaram-me que um pouco mais sobre essas divisões. Segundo o Nêgo Gerson, eles chegam por duas correntes, uma branca e outra preta. A corrente branca se parte em várias linhas de diferentes cores que passam por vários lugares - como o mar, as matas, os astros... - e abrem caminhos para algumas entidades que neles estão, mas nem todas, somente os

${ }^{23}$ As considerações propostas por Sztutman (2005a, 2005b), que parte das ideias de Stengers, Latour e Viveiros de Castro sobre as cosmopolíticas ameríndias, foram essenciais para as reflexões que aqui exponho sobre as relações entre diferentes mundos mediadas pelos pajés tremembés. 
encantados, também chamados de caboclos, guias ou mestres, que vêm ao mundo terreno para ajudar as pessoas necessitadas de curas ou outra graça qualquer. Outras entidades, os espíritos maléficos só podem passar através da corrente preta. Esta corrente só desemboca em uma linha: a linha preta, por onde podem passar quaisquer entidades que são invocadas em rituais que meus interlocutores identificaram como sendo de macumba ou de magia negra. Todos os pajés que conheci em campo afirmaram não trabalhar com essa corrente. Quando algum espírito maligno baixa em seus rituais, tratam de afastá-lo dali através de poderosas orações capazes de prendê-los em outras dimensões. Transcrevo abaixo um pequeno trecho da conversa entre mim e o Nêgo Gerson:

Juliana: o senhor vem da onde?

NG: Eu venho agora do mar sagrado. Depende da nossa corrente, porque não é preciso nós vim de todas as correntes, tem as corrente de nós manejar nosso trabalho. Depende das precisão dos meus filhos, a moça ta entendendo? Se for uma coisa pesada, se for um problema mais pesado, nós já muda nosso caminho, ta entendendo? Se for outra coisa mais pesada, já muda pra outra... Mas que o Nêgo Gerson trabalha com todas... A menina fez muito bem de me perguntar esse problema porque os meus filhos muitas vezes não entende as coisas. Se for uma coisa difícil, o quê que nós pode fazer? É mudar a corrente e mudar o preparamento, entendeu? Mudar os apreparo, porque se for cortar uma coisa com um ferro cego, ele não corta. Depende... Se for um pau grosso, tem que ser um ferro bem bom. Mesmo assim é as corrente.

Evandro: as corrente hoje [do ritual que participávamos] é branca, né? Corrente de limpeza...

NG: É corrente branca... Uma parte da linha branca, né? Então, se for outra coisa, já muda de corrente, passa pra uma corrente de linha roxa, pertence a uma corrente de linha verde, pertence uma corrente de linha marrom, ta entendendo? Então depende das corrente... Tem a corrente de linha azul também...

Participante: tem a corente de linha preta, tem?

NG: tem. Essa é a perigosa, né? Porque ela não tem galho, é só uma corrente direta, então o que que acontece? É como diz o ditado de vocês, entra o porco e entra o bode. Só entra o que não presta, porque ela é descambada! Ela é descambada, anda todo inseto nela, né? Anda o capeta, anda os espírito mal, anda as coisas mal, ta entendendo? É a corrente própria da macumba, né? Aí já pertence ao outro lado, ta entendendo? Pra vocês, um dia se vocês foram pra qualquer audiência, que às vezes vocês não entende, vocês se benzam bem, vocês rezem bem pra não pegar alguma coisa do mal, né? Porque é uma descambada, entendeu? Aonde tem ela, ninguém fala em deus. Porque aí é que é a corrente do capeta, ta entendendo? Porque tem a corrente branca que pertence à Umbanda, pertence à Jurema, pertence essas coisas, ta 
entendendo? Aí tudo é galho, tudo é branco, mas ela [a corrente preta] é só uma, ela não tem galho, é uma corrente direta, então, quando ela parte logo, é pra dentro das profundas, sabe? Ela parte logo direto, ela não tem galho pra nenhum canto. E a corrente branca, ela tem galho, ta entendendo? Ela pertence a umas pouca de qualidade. Vocês prestem atenção nos apreparo, ta entendendo? Quando vocês forem num trabalho que tiver os apreparo dela que tiver vela preta pelo meio, vocês prestem atenção, quando ela desce, se ela tem galho. A branca, ela tem galho, é vela vermelha, é vela branca, é vela roxa, é vela amarela... isso aí tudo é galho da corrente branca, mas ela não tem galho, ela só tem uma cor. É direto. Ela só tem uma cor que é só preta.

A polarização entre as entidades que vêm para fazer o bem e as entidades malignas é muito recorrente. Embora não haja um consenso sobre as diversas linhas e correntes existentes, as questões sobre a corrente preta são consensuais: por ela podem passar quaisquer entidades mal-intencionadas. Por isso, como observa o Nêgo Gerson na conversa acima, as relações que entidades da corrente preta estabelecem com os humanos são bem diferentes daquelas da corrente branca, por isso os apreparos, ou seja, os rituais que pelos quais elas são invocadas são diferentes e é preciso ter um cuidado maior com elas, já que elas podem causar tantos males. Em geral, diz-se que enquanto pelas correntes brancas baixam encantados, que vêm para nos trazer benesses, pelas pretas baixam quaisquer espíritos malignos, entidades que estariam a serviço do demônio, enquanto as primeiras eram benignas e "envidas por deus", o que denota oposição entre deus e o demônio.

Podemos observar também que as entidades têm uma mobilidade que as possibilita passar por várias linhas, que constituem caminhos que os conduzem por lugares como matas, águas ou astros, de onde eles trazem aquilo que precisam para resolver cada tipo de demanda que aparece nos trabalhos. Cada um desses lugares porta uma força capaz de resolver demandas específicas. Várias das pajés que conheci em campo me explicaram que a força dos seus trabalhos depende da linha a qual ele pertence. Dona Francisca, por exemplo, me disse várias vezes que 
trabalhava com a força que vinha do mar, das matas e do Maranhão, por onde também passa uma das linhas.

Algumas pessoas - os médiuns, que podem vir a tornarem-se pajés - têm uma coroa na cabeça que se abre a correntes ou linhas específicas. É pela coroa que as correntes arriam, sendo necessário suspendê-las através dos trabalhos de pajés já desenvolvidos. Contudo, quando a mediunidade é muito avançada, os chamados se dão em intervalos cada vez mais curtos, até que as correntes arriam de vez, é quando as entidades não cessam de descer, tomando seus corpos até que a pessoa decida por desenvolver-se ou viver em um constante sofrimento.

Entretanto, se, mesmo diante do sofrimento, uma pessoa com uma forte mediunidade se recuse a desenvolver esse dom, as entidades nunca desistirão de procurá-la e perturbar suas vidas. Em outras palavras, ocorre uma retaliação aos que não aceitam transmitir a cura e fazer, assim, a comunicação entre o "nosso" e o "outro mundo". As entidades chegam a castigá-las, fazendo-lhes adoecer ou provocando conflitos familiares, geralmente, associados à alcoolização. Os primeiros rituais que presenciei em campo, inclusive, tratavam-se da cura de um rapaz que, nos últimos meses, havia deixado todos os seus afazeres de lado e bebia quase todos os dias. Sua mãe, Dona Elita - pajé da qual ainda falarei nesse texto procurava afastar dele a entidade que o assolava. Depois do ritual, ela me disse que o caso estava a acontecer porque seu filho não queria trabalhar como a mãe, então ficava vulnerável a qualquer entidade que se apoderasse do seu corpo, já que ele era médium e não desenvolvia seu dom. Já os pajés, aprenderam a lidar com essas situações e não recebem mais qualquer entidade, apenas os encantados que se dispõem a ajudar a eles e aos que os procuram.

Ainda assim, muitas pessoas "escolhidas" pelos encantados optam por não se desenvolver, pois temem que, no momento da incorporação, seus espíritos não consigam retornar e elas acabem morrendo, muito embora, ninguém tenha me contado episódio algum onde isso tenha acontecido, ainda assim é considerada uma atividade que 
envolve muitos riscos. Mas, além dos riscos inerentes ao contato com esse "outro mundo", há também vários outros fatores que fazem as pessoas desistirem da tarefa de trabalhar com os encantados. A principal delas consiste no estigma que pesa sobre estes trabalhos, identificados, frequentemente, como rituais "demoníacos", sobretudo pelas pessoas ligadas a religiões protestantes. Tal assunto ainda será abordado nesta tese.

Na busca de conhecer tais trabalhos, eu e o professor Messeder procuramos, logo nos primeiros dias de campo, uma pajé muito reverenciada pelos membros do grupo, Dona Maria Bela, moradora da região da Praia de Almofala, falecida recentemente, em outubro de 2015. $\mathrm{Na}$ época, portávamos o velho gravador de fita cassete, com capacidade de uma hora de gravação cada, e, com pesar, podemos gravar somente duas horas da nossa longa conversa. Nela, Dona Maria Bela descortinava aos nossos olhos um universo de seres encantados que se apresentavam a ela desde os nove anos de idade. Abaixo transcrevo um trecho da nossa conversa no qual ela conta sua primeira visão:

Quando foi um dia, eu fui tomar banho, lá na dita levada, quando se surgiu uma cobra grande e grossa que me laçou, mas ela não me apertou e também não me mordeu, ela botou a língua pra fora e olhou pra mim e eu olhei pra ela, a língua não era rachada - que língua de cobra é rachada, é feito forquilha - a dela não era rachada, os olho azul como uma pedra de anil! Ela lambeu a coroa da minha cabeça e lambeu num braço e noutro e lambeu nas minhas costa e lambeu aqui na minha... aqui entre os peito [fazendo um sinal de cruz] e aí se saiu e entrou num buraquinho que tinha assim, que eu tinha feito assim com uma quenga (brincadeira de menino) e eu chamei os homem e eles vieram e cavaram e não encontraram a cobra. Aí eu saí no rumo de casa chorando. Aí foram atrás do pajé véi, que era o tio João Cosme, aí ele veio e disse que eu tinha uma vidência, que eu era médium. Então aquele negócio tinha vindo pra me dar força e fazer todos os trabalhos pra mim. Aí ele foi e me benzeu, me ajeitou, disse que era com 14 ano [que os encantados voltariam].

Desde então, o assunto tornou-se meu principal interesse em campo, embora, nos primeiros meses de pesquisa, não tenha conseguido dedicar-me totalmente a ele por conta da pesquisa de Messeder, concluído 
este trabalho, dediquei-me a investigar mais detalhadamente as histórias das pajés Tremembé. E resolvi escrever a monografia da graduação sobre Dona Maria Bela e suas práticas curativas ${ }^{24}$. Posteriormente, no mestrado, pude aprofundar tal pesquisa, abrangendo meu estudo para outras pajés que havia conhecido em Almofala. ${ }^{25} \mathrm{O}$ fato de eu ter escolhido trabalhar apenas com as mulheres pajés - embora também haja pajés homens na região - teve múltiplas razões. Um fator importante foi que, o ano de 2009, quando realizei a pesquisa de campo do mestrado, foi um ano de chuvas intensas no Ceará, então o acesso a muitas das localidades era restrito, assim, fui obrigada a limitar a pesquisa apenas às localidades da Praia de Almofala, Varjota e Tapera. Nessas áreas havia somente pajés mulheres ${ }^{26}$ e foi com elas que resolvi trabalhar. Entretanto, na medida em que a pesquisa se desenvolvia, percebi que havia algo mais complexo a ser tratado no caso das pajés tremembés, conforme evidenciarei a seguir.

\subsection{Trabalho de encante: as trajetórias das pajés Tremembé}

Nessa etapa da pesquisa, trabalhei com quatro pajés, Dona Elita, Dona Maria Bela, Dona Lucrécia e Dona Francisca. A primeira mora na Varjota, a segunda na Praia e as duas últimas na Tapera. Excetuando Dona Maria Bela, que começou a desenvolver seu dom ainda criança, todas as outras relatavam que, embora desde crianças apresentassem sinais de vidência, somente depois do casamento suas correntes arriaram de vez, obrigando-Ihes a procurar um pajé e dar início aos trabalhos de cura. Elas contam, conforme detalho na dissertação, que - não se sabe exatamente por qual motivo - deus confere a algumas pessoas o dom de se

\footnotetext{
24 GONDIM, Juliana M. Dona Maria Bela: suas curas e seus encantes. Monografia de graduação em Ciências Sociais, UFC, 2007.

25 GONDIM, Juliana M. "Não tem caminho que nós não ande e nem tem mal que nós não cure": narrativas e práticas rituais das pajés tremembés. Dissertação apresentada ao Programa de Pós-Graduação em Sociologia da Universidade Federal do Ceará. 2010.

${ }^{26}$ Refiro-me aqui apenas às pessoas que trabalham com incorporação, pois há também rezadeiros e rezadeiras nessas localidades, o pajé Luís Caboclo, inclusive, mora na Varjota.
} 
comunicarem com os encantados. A elas cabe procurar alguém mais experiente que lhes possa ajudar desenvolver este dom e, assim, controlar a experiência da possessão, já que, quando começam a se manifestar, não só os encantados, mas quaisquer outras entidades, inclusive espíritos malignos, podem tomar conta de seus corpos a qualquer hora, tirandoIhes o sossego.

Todas elas se referem à experiência da revelação como algo muito doloroso, uma fase muito dramática de suas vidas, pois seus sintomas eram concebidos por muitos familiares e vizinhos - e, às vezes, até por elas mesmas - como loucura. Durante as entrevistas que realizei sobre o assunto, era comum as pajés recorrerem à ajuda de seus respectivos maridos para que eles contassem detalhes dos fatos, pois diziam não guardarem muitas lembranças, já que perdiam os sentidos quando as entidades as possuíam. As mulheres começam a mudar de humor e recusam-se às tarefas domésticas, deixando de lado o habitual cuidado com seus respectivos maridos, filhos e suas casas. Contam que o pensamento começa a ficar distante, começam a ouvir vozes que as confundem e elas não conseguem desenvolver as tarefas a elas concedidas.

Alguns elementos facilitavam o acesso ao "outro mundo", pois ao entrarem em contato com objeto trazidos do mar nas pescarias dos maridos ou irmãos, como búzios, conchas ou redes de pesca, ou quando se molhavam nas águas do mar, dos rios e lagos, elas tinham alucinações e chagavam a desmaiar. Ou seja, tais elementos serviam de elo para que elas entrassem em contato com o "outro lado", como também se referem ao mundo dos encantados. Quando tais sintomas se intensificavam, as entidades tomavam conta de seus corpos, as fazendo agir de forma extraordinária. Conforme os depoimentos dos maridos, elas ficavam com uma força imensa, além disso, pegavam em brasa sem se queimar e mudavam a voz. Não raro saiam a correr pelo mundo afora, sem rumo, desnorteadas até serem encontradas sozinhas e desacordadas pelos arredores de casa. 
No trecho abaixo, Seu Sabino conta como se deu o processo de iniciação de sua esposa, Dona Lucrécia:

(...) ela começou um problema que quando ela tinha uma criança, ela não dava de mamar à criança (...) porque lascava os peito, os bico dos peito lascava que ficava na carne, dum lado e outro (...) as crianças foram criadas com leite mesmo da bodega, porque ela mesma não podia. Na conta de um mês, que era a conta do resguardo dela, né? Na conta de um mês, ela não dava mais de mamar a menino (...). Até que um dia, aconteceu d'eu levar ela pra uma mulher lá no Cedro, ela era macumbeira, só que ela trabalhava nesses trabalho. (...) Aí, de lá pra cá, a mulher rezou nela lá, aí mandou que nós fosse lá depois, num dia de sexta-feira, nós fosse lá $(\ldots)$ aí ela foi e disse que ela era uma média de nascença, ela já tinha nascido com a coroazinha dela e ela tinha o jeito de trabalhar, ela tinha que trabalhar, ou ela trabalhava ou ela ficava doida. (...) se ela passar, mais ou menos, assim uns quinze dias sem trabalhar, ela se dá mal.

Recentemente, conheci a mais jovem pajé do grupo, Delly, moradora do Mangue Alto, de aproximadamente 20 anos de idade. Ela me contou que, desde bem cedo tinha as mesmas sensações descritas pelas demais pajés com que trabalhei no mestrado. Quando completou 15 anos, ela começou a ser acometida por fortes dores de cabeça, seu sono começou a ficar agitado e ela tinha pesadelos constantes. Eram os encantados começando a chegar na sua coroa. Havia certos dias em que acordava sentindo uma tristeza, um medo ou um mau-humor inexplicáveis e optava por ficar em casa, realizando suas tarefas habituais para evitar quaisquer imprevistos, mas, ainda assim, perdia a consciência inesperadamente. Quando acordava, geralmente estava em meio a algum matagal e suas irmãs contavam-Ihe várias coisas que ela havia feito, ainda que não guardasse lembranças de absolutamente nada. Este quadro provocava nela profusões de sentimentos e angústias que as levavam a duvidar da sua sanidade física e mental, afora isso, ainda sentia muita vergonha das coisas que fazia quando estava em transe. Suas angústias eram ainda mais intensas porque não sabia o que estava acontecendo consigo. Ao comentar o assunto com amigos, muitos diziam que ela estava sendo possuída por espíritos malignos ou que estava enlouquecendo. 
A época em que Delly estava começando a receber os seus caboclos coincidiu com o seu ingresso no Ensino Médio, então recém criado na Escola Maria Venância. Foi quando ela, sob orientação dos professores, começou a pesquisar sobre as histórias dos encantados e as práticas curativas a eles relacionadas. Além disso, nessa fase, os adolescentes começam a participar com mais assiduidade dos eventos políticos, principalmente as assembleias, onde ocorre, frequentemente, muitas situações que favorecem ao transe de alguns presentes que acabam por revelar suas capacidades mediúnicas. Falarei sobre isso mais adiante. Em uma dessas assembleias, ela conheceu uma pajé que mora na Batedeira, Dona Rita, que se dispôs a suspender temporariamente suas correntes. Logo nos primeiros trabalhos, Dona Rita constatou que suas correntes estavam muito fortes, então, dentro em breve, não seria mais possível suspendê-las. Diante disso, Delly resolveu começar a trabalhar logo e desenvolver seu dom, já que não seria possível adiar essa situação por muito tempo. Ela ressalta que o apoio de suas irmãs, algumas delas também professoras nas escolas diferenciadas, foi essencial para que ela aceitasse o dom, pois elas tentavam fazê-la entender que não havia nada de errado no que estava acontecendo, ao contrário, tratava-se de um chamado importante, de entidades que estavam dispostas a ajudar a ela e aos que a cercavam. Ademais, conforme asseveravam seus professores, tais trabalhos faziam parte da "cultura" Tremembé, ou seja, eram uma porta aberta à produção de conhecimentos que ela teria acesso através dos encantados. Sua mãe, entretanto, continuava desgostosa de ver a filha trabalhando com os caboclos, pois muitas pessoas da família - tios e primos, católicos e evangélicos - diziam tratar-se de seres mandados pelo "inimigo" - como também se referem ao demônio -, já que, pela "lei de deus" aqueles que morrem não são autorizados a voltar a esse mundo, assim, os que voltam vêm a mando do demônio. O fato que fez sua mãe e muitos outros parentes mudar de ideia em relação a ela e seu dom foi uma conversa travada com o padre da Paróquia de Almofala que explicou à sua mãe que seu trabalho não estava ligado a forças demoníacas como muitos 
diziam, pois o demônio não apareceria na terra para curar enfermos ou trazer quaisquer outros benefícios, muito pelo contrário, as pessoas a quem era dado o dom de rezar e praticar as curas agiam pelas graças de deus e, por isso, a elas todos os outros deveriam ser gratos.

Delly salienta que o que a fez decidir por aceitar o dom foi o fato de que Dona Rita esclareceu que os caboclos que desceriam na sua coroa eram da linha "do bem", não viriam para lançar feitiços ou quaisquer "coisas ruins" às outras pessoas. Se assim fosse, ela reforça que não teria aceito o trabalho, ainda que as entidades a fizessem sofrer.

Não só no caso de Delly, mas em todos os outros, os sintomas que revelam o dom só cessavam quando se recorrem a pajés - índios ou não ${ }^{27}$ - e passam a frequentar centros de Umbanda, aprendendo, assim, a se desenvolver, ou seja, a controlar as incorporações e lidar com o dom que haviam recebido. Quando se referem a este período de suas vidas, as pessoas lembram dos pajés que as desenvolveram com carinho e gratidão, contudo - quando não se trata de um parente ou vizinho com quem continuam mantendo contato por outras vias que não os rituais - elas acabam se afastando deles e não se sentem obrigadas a manter tais laços, pois, geralmente são pessoas que moram longe de suas casas, às vezes até em outras cidades.

Após serem desenvolvidas, elas começavam a incorporar tais seres somente em rituais realizados nos seus centros, como elas chamam os pequenos galpões que constroem nos terreiros de suas casas para realizarem as incorporações. Quando não têm condições ou espaço para construir seus centros, elas realizam seus rituais nas suas casas mesmo, nas salas ou cozinhas. Mas preferem, quando podem, construir um espaço reservado à realização do ritual, pois afirmam não ser muito seguro misturar o espaço doméstico com o espaço ritual. Isso porque, muitas pessoas que as procuram chegam carregadas e, no processo de descarrego, o ambiente pode ser contaminado. O ritual de descarrego é

27 Lembrando que as pessoas que trabalham com incorporação, sendo ou não índias, são chamadas de pajés entre os Tremembé. 
também chamado de limpeza. Consiste, então em uma prática de afastar das pessoas que as procuram qualquer espírito ruim, feitiço ou mau-olhado, por isso é preciso haver um local apropriado e separado do ambiente familiar para afastar o risco de doenças ou maus espíritos permanecerem por perto.

Assim, sempre que podem as pajés constroem centros, que são pequenos quartos situados nos fundos ou nos arredores de suas casas, mobiliados apenas com alguns banquinhos ou cadeiras, uma mesinha que faz as vezes de altar e abriga as mais diversas imagens de santos católicos ou entidades de Umbanda. São estatuetas de gesso ou retratos de papel, alguns deles emoldurados, todos os personagens retratados são classificados como encantados.

Às vezes ocorre de, mesmo após terem construído seus centros, as pajés cederem a construção para abrigar a família de algum filho ou filha que se casa e precisa de um lugar para morar. Isso aconteceu com duas das pajés que conheci, Dona Lucrécia e Dona Maria Bela. A primeira explicou-me isso no dia em que a conheci, convidando-me a entrar na sua casa, mostrou a sala onde praticava seus trabalhos e explicou que a pequena construção ao lado de casa um dia serviu-Ihe de centro, mas agora dava lugar à filha e ao marido que haviam tido um bebê recentemente. Ela dizia que não precisava de muitos esforços para preparar sua sala para os trabalhos, já que o cômodo continha mesmo poucos móveis, dando espaço para os participantes se situarem ao redor da mesa, cantarem os pontos e as vezes, baiarem, ou seja, dançarem embalados pelos pontos dos caboclos, assim, ela apenas arrumava a mesa com as poucas imagens que guardava no armário e dava início ao ritual. Já Dona Maria Bela, pouco antes de falecer, tinha readaptado seu centro para que servisse de moradia para um neto e a esposa. Todavia, no seu caso, ela construiu um cômodo a mais no centro, onde continuou realizando seus trabalhos e guardando suas imagens. Aliás, um forte motivo apontado pelas pajés como uma das razões pelas quais elas construíam seus centros fora de suas casas era que elas não tinham lugares adequados para guardar suas imagens, que 
ficavam largadas, sujeitas às traquinagens das crianças que, descuidadas, acabavam quebrando muitas delas e destruindo o altar tão bem enfeitado para os rituais.

Como já mencionei, as próprias pajés, bem como as pessoas que a elas recorrem, denominam tais rituais como trabalhos de Umbanda, mas usam também outros termos para se referirem a eles, como tundá, trabalhos de mesa, trabalhos de encantados ou, como afirma Dona Francisca, "de encante. Meu trabalho é da família de Umbanda, é dos encante do mar, da mata, do Maranhão... Tudo é trabalho de encante, da família de Umbanda".

Em linhas gerais, o ritual é muito semelhante aos rituais de Umbanda, entretanto, numa análise mais detalhada, observamos várias diferenças entre tais rituais e outros que pude presenciar em Fortaleza e mesmo nas proximidades de Almofala, em terreiros de não índios. Em primeiro lugar, não há uma regularidade na atividade ritual como nos terreiros de Umbanda, as pajés só costumam "abrir mesa" quando são procuradas por pessoas em busca de curas ou quando os próprios encantados solicitam seus trabalhos, pois, de tempos em tempos, mesmo que não haja a necessidade imediata de praticar a cura, as pajés devem realizar seus trabalhos como uma obrigação para com os encantados.

Os trabalhos se desenrolam sempre da mesma forma: inicialmente, elas rezam, acendem velas para seus guias e, então começam a incorporar as entidades. Cada uma delas tem um mestre, eles são descritos como entidades responsáveis por guardar seus espíritos enquanto os encantados nelas se incorporam. Como elas perdem os sentidos na incorporação, necessitam de ajuda para lembrar das prescrições dos encantados, para isso contam com o auxílio de um ponta de mesa ou cambone, como são chamados seus auxiliares. Geralmente, são seus respectivos maridos que desempenham este papel. No caso de Dona Maria Bela, que era viúva, sua filha, Camila, era quem ajudava no trabalho. Já Delly, é ajudada pelas irmãs. 
Logo que a entidade se incorpora, dirige-se ao ponta de mesa pedindo "Dai-me passagem?", e ele responde "Passagem dada!", em seguida pergunta a todos "Tem quem possa mais do que deus?" e ao que respondem "Mais do que deus ninguém!", então a entidade canta seu respectivo ponto, como são denominadas as cantigas específicas de cada uma delas e, quando necessário, conversam com algum dos participantes para indicar a cura para seus males. Assim, desenrola-se uma sucessão de incorporações de entidades do panteão umbandista, até que elas próprias decidam parar de baixar. Quando o ritual demora muito, entretanto, os próprios pontas de mesa solicitam que as entidades parem. Todos os rituais que presenciei contavam com a presença de poucos participantes, geralmente apenas aqueles que estavam à procura de cura, no máximo cinco pessoas. Na maioria das vezes, eles se desenrolam com duas ou três pessoas, além da pajé e de seu auxiliar.

Diferente do que acontece nos demais terreiros de Umbanda que conheci, nesses rituais é vetado às entidades o consumo do álcool, apesar de muitas delas, como o Zé Pilintra, o Nêgo Gerson, entre outras, baixarem pedindo bebida alcoólica. O pedido, porém, é negado veementemente. É muito comum, nesse momento do ritual, as pajés repreenderem as entidades e darem-Ihes conselhos para não beberem e, assim, servirem de exemplo aos demais. No primeiro ritual do qual participei, esse fato me soou muito estranho, pois, em todos os rituais de Umbanda que eu já havia presenciado, a ingestão do álcool pelas entidades é muito comum, aliás, elas nunca são repreendidas, ao contrário, devem ser prontamente atendidas em todos os seus pedidos, seja de álcool, cigarro ou charutos. Nos Tremembé, as pajés se utilizam somente do cigarro feito com fumo de rolo e, para beber, dão aos que nelas se incorporam água com açúcar - a chamada garapa. Quando fui convidada para conhecer os rituais, inclusive, me foi recomendado levar velas, açúcar e fumo, como é costume para aqueles que vão em busca de conhecer tais rituais. $O$ momento em que as entidades pedem bebida alcoólica é de muita descontração, pois se torna motivo de piada entre os presentes. Isto porque as pajés, diante da 
insistência de alguns deles em beberem álcool, respondem com certa irritação, com frases do tipo "Tá pensando que isso aqui é o que, rapaz? Aqui não é lugar de beber cachaça, é uma casa de respeito! Crie vergonha!". Ou seja, nesse momento, ocorre uma teatralização, no ritual, à repressão ao uso do álcool, o que não é de se estranhar, pois os dramas da alcoolização são presentes em muitas das famílias, inclusive de algumas das pajés com as quais trabalhei. Num instigante trabalho sobre o tema, Messeder (2005), na sua já citada tese de doutorado, trata do consumo do álcool entre os Tremembé, abordando o aspecto ritualístico que envolve o ato de beber no cotidiano, entre amigos ou no ritual do torém, sem se esquecer das questões ideológicas associadas ao uso do álcool e do estigma que pesa sobre seus usuários.

$O$ fato de todas as pajés que conheci em Almofala negarem-se ao consumo do álcool tem várias implicações. Há uma reivindicação moral, nesse ato. Sempre que tocam nesse assunto, elas reafirmam que, caso bebessem em seus rituais, as pessoas que as procuram não teriam confiança dos seus trabalhos, não saberiam se estariam de fato incorporadas pelos encantados ou se estariam agindo sob efeito do álcool. Mas há algo que vai muito além disso, elas julgam que, se bebessem, não teriam legitimidade para curar aqueles que as procuram para se livrarem do consumo excessivo do álcool - cura muito requisitada frente ao problema da alcoolização enfrentado por muitas das famílias Tremembé. Ou seja, para aquele que exerce a função de pajé é necessário, também, além de ter sido "escolhido", ter uma conduta moral que envolve muitos atributos, tais como ter coragem, generosidade, honra. As pajés salientam muito estas características em si próprias, quando, por exemplo, destacam que não bebem, não cobram por seus serviços nem deixam de curar aqueles que as procuram e nem trabalham com as entidades que descem pelas linhas pretas.

O exemplo do tratamento das pajés em relação às entidades que baixam pedindo bebida também mostra que, embora haja entre as pajés e os seres que elas incorporam uma profunda admiração e gratidão, não se 
configura aí uma relação de submissão em relação a eles. Ao mesmo tempo em que elas precisam dos encantados para praticarem a cura nelas próprias e nos demais, e, por isso, nutrem por eles um sentimento de gratidão, elas se dão ao direito de lhes aconselhar e, ainda mais, ralhar com eles. $O$ fato de se recusarem a ingerir bebida alcoólica quando estão incorporadas é apenas mais um exemplo claro disso, mas em várias ocasiões do ritual, observamos um clima de muita informalidade quando os participantes se dirigem aos encantados. Por exemplo, quando o ritual se estende até tarde, seus auxiliares solicitam, "sem muita cerimônia", dos encantados que encerrem as atividades ${ }^{28}$, com frases como "Tá bom, vamos deixar a cumade descansar!" ou "Vocês não acham que tá bom, não? A gente também tem o que fazer em casa, tem que trabalhar amanhã cedo...". Os outros participantes do ritual, eventualmente, também dão opiniões e entram nas conversas... E assim as coisas vão-se desenrolando numa atmosfera de descontração.

Apesar de as pajés classificarem seus trabalhos como sendo de Umbanda, elas próprias, em muitos momentos, demarcam algumas diferenças entre os rituais por elas praticados, em seus centros e suas casas, e aqueles praticados nos terreiros de Umbanda, registrados na Federação Cearense de Umbanda. Além dos centros das pajés Tremembé, conheci dois desses terreiros nas proximidades de Almofala, um situado na localidade de Torrões, cujo dono era Seu Raimundo Ipoute, já falecido, e o outro conheci mais recentemente, já no ano de 2013, de Dona Mariazinha, na localidade do Córrego das Moças ${ }^{29}$. Ambos reconhecem o respaldo das práticas curativas das pajés de Almofala - sobretudo de Dona Maria Bela, que é muito conhecida na região por seus trabalhos - mas Seu Raimundo diz não reconhecer tais trabalhos como sendo de Umbanda, pois diferente

28 Os rituais geralmente se iniciam por volta das oito horas da noite e não costumam chegar à meia noite.

${ }^{29}$ Ambas as localidades estão fora da área indígena, mas pela há relações bem próximas entre seus moradores, inclusive de parentesco. 
do que ocorre em seus terreiros, os centros das pajés de Almofala não são registrados na Federação, conforme explicita o trecho seu depoimento:

Esses negócio que chama negócio de tundá é índio. Os índio, né? E de Umbanda é de outro trabalho, da Federação de Umbanda. E tundá não tem licença, ninguém não paga nada. Agora de Umbanda tem licença, é pago todos os ano.

Dona Mariazinha, disse já ter ouvido falar das atividades curativas de Dona Maria Bela, mas nunca a conheceu pessoalmente, por isso, não sabia se tais atividades seriam mesmo de Umbanda, pois, também para ela, estes terreiros só seriam reconhecidos se fossem cadastrados. As pajés, entretanto, embora exerçam com frequência suas atividades rituais, não sinalizam a necessidade de institucionalização, pois nenhuma delas é registrada oficialmente. Ainda assim, classificam suas práticas como umbandistas.

Já nos eventos políticos do grupo, as lideranças sempre se referem a práticas curativas que envolvem encantados como trabalhos de encantados. Ou seja, na medida em que se faz necessário demarcar diferenças identitárias, tais trabalhos assumem, no discurso político do grupo, um lugar de diferenciação em relação aos trabalhos de Umbanda, praticados por não índios. Entretanto, a forma como os Tremembé compreendem os encantados e os rituais a eles relacionados vai bem mais além das questões étnicas e ao discurso político.

As atividades políticas do grupo, sobretudo as assembleias, são momentos que favorecem manifestações de seres não humanos, encantados ou não. Sobre tais ocasiões, muitos me explicaram que, por serem situações em que os problemas políticos, relacionados à demarcação da terra, à devastação ambiental e o direito à saúde e educação diferenciadas são calorosamente debatidos, e, a todo momento, é solicitada a ajuda dos encantados para dar força ao movimento. Contudo, essas situações podem atrair não só os encantados, mas outras entidades, malintencionadas, que se aproveitam da ocasião e podem encostar em pessoas que estejam mais vulneráveis. Em todas as assembleias que participei, 
o cacique e o pajé alertam para este fato e aconselham os participantes a se protegerem e procurarem estar fortes para evitar que maus espíritos dominem seus corpos, pois já aconteceram muitas ocasiões em que, durante a assembleia, nos intervalos das atividades ou nas rodas de torém, as pessoas incorporarem espíritos e precisarem da ajuda de pajés para solucionar o problema.

Não é comum que se recebam espíritos nas rodas de torém. Como salientou Oliveira Jr (1997), na sua dissertação sobre esta dança, as rodas de torém são organizadas em geral, em momentos lúdicos e é uma dança lúdica. Todavia, no processo de reorganização política, a dança foi utilizada como um forte elemento de distinção frente à sociedade não índia, tornando-se, assim, um artifício importante no discurso político do grupo. Destarte, nos momentos de reuniões políticas, dançam o torém como forma de saudar os antepassados e reafirmar a identidade indígena.

Nos momentos em que a dança é praticada em festas internas da comunidade - casamentos ou outras comemorações - nunca observei nenhuma manifestação de seres não humanos. Somente nos momentos que envolvem debates e organização política. Aí sim, seres que intentam atrapalhar a organização política dos índios podem aproveitar-se da situação e se apoderam de pessoas que não têm força. A força é um atributo daqueles que, ainda que não sejam pajés, conseguem adquirir a proteção dos encantados contra seres malignos.

Ou seja, os pajés, então, são um elo de comunicação entre mundos. Somente eles, entre os humanos, têm o poder de resolver os conflitos entre agentes humanos e não humanos. Nesse sentido, podemos aproximar as análises dos dados aqui apresentados às considerações elaboradas por Sztutman (2005) ao versar sobre a ação xamânica nas Guianas, onde ele admite estar diante de uma ação política particular: uma cosmopolítica, já que se trata de uma interpenetração entre diferentes mundos.

Para desvendarmos as nuances dessa cosmopolítica que envolve agentes humanos e não humanos em Almofala, é preciso investigar com 
mais afinco as práticas, atribuições e saberes relacionados à cura. Pois, além dos trabalhos de Umbanda, aos quais os membros do grupo recorrem em busca de solução para seus problemas cotidianos, há algumas atividades curativas que também mobilizam seres encantados, embora não ocorra a incorporação. São as rezas.

\subsection{Rezadeiras e Curadores: a cura fora dos rituais de incorporação}

As rezas são rituais de cura praticados por algumas pessoas denominadas rezadores/rezadeiras ou curadores/curadeiras. Como a grande maioria dessas pessoas são mulheres, doravante, referir-me-ei a elas como rezadeiras. Todos os pajés que conheci fazem também rituais de reza, porém, o contrário não ocorre, a grande maioria das rezadeiras não trabalha com incorporação, embora algumas delas - as que têm uma reza forte - também consigam expulsar espíritos malignos que se apoderam das pessoas, mas são ocorrências raras, quando não há um pajé já experiente e que trabalhe com caboclos que possa tomar à frente da situação. As rezadeiras que têm essa capacidade são muitas vezes, também chamadas de pajés, ou seja, a categoria "pajé" perpassa várias práticas e saberes relacionados com a cura, não só as práticas ligadas à Umbanda.

Diferente dos pajés que trabalham com incorporação, que são escolhidos por uma enunciação de deus, no caso das rezadeiras, elas mesmas decidem pegar a reza, ou seja, aprender com as mais velhas as práticas e os saberes que envolvem o ato de rezar. Todas as rezadeiras que conheci afirmam que aprenderam o ofício com algum parente ou vizinho mais velho, geralmente a mãe. Contam que, desde crianças, quando viam as curas praticadas pelas rezadeiras, ficavam comovidas com o ritual e os benefícios que ele traz àqueles que as procuravam, então, a certa altura de suas vidas, quando se sentiam fortes o suficiente para pegar as rezas, elas pedem às rezadeiras mais velhas que as ensinem as palavras tão bem guardadas em segredo. Por outro lado, muitas rezadeiras se queixam de que não há mais, nas gerações mais jovens, pessoas que se dispõem a dar 
continuidade às rezas, por ser esse um ofício árduo, já que elas devem estar sempre disponíveis para aqueles que as procuram a qualquer hora do dia ou da noite em busca de curas. Além disso, muitas pessoas têm medo de ser contaminadas pelas "coisas ruins" que geram as doenças naqueles que as procuram.

Trata-se, portanto, assim como o ofício das pajés que trabalham com incorporação, de um trabalho extremamente perigoso e que requer muita força ${ }^{30}$. Diz-se que só as pessoas fortes conseguem pegar as rezas, pois, assim como ocorre nos rituais de incorporação já descritos, as rezas também podem deixar vestígios nos locais onde são realizadas ou nas pessoas que as realizam, que devem, portanto, estar preparadas e fortes de espírito para rebater tais ações.

Muitas das histórias são deveras comoventes, são casos de crianças que chegam desfalecidas, muitas vezes desenganadas pelos médicos que lançam mão de vários artifícios para reanimar os enfermos, mas de nada valem, pois - como explicam as rezadeiras - não se tratam de males que afetam somente os corpos, antes disso os espíritos são afetados, portanto não serão eficazes remédios que só servem para os corpos.

Há vários tipos de rezas que curam vários males diferentes. E há também uma pluralidade imensa de práticas ligadas às rezas, algumas rezadeiras usam materiais como linha e agulha para "costurar o mal", e vão costurando em um pedacinho de pano posto sobre a parte do corpo afetada pela enfermidade, com o objetivo de prender a doença no paninho, enquanto pronunciam algumas palavras. Outras pronunciam as rezas enquanto passam um galho de alguma planta - geralmente pinhão roxo (Jatropha gossypiifolia) ou arruda (Ruta graveolens) fazendo movimentos em cruz e no sentido de fora para dentro do corpo, como forma de jogar a doença para fora.

30 No capítulo seguinte, tratarei mais acuradamente sobre a categoria "força" para os Tremembé. 
Mas, na grande maioria dos casos, as rezadeiras são procuradas para curar mau-olhado, principalmente de bebês recém-nascidos, pois eles são mais suscetíveis às doenças causadas por inveja. Algumas pessoas, mesmo sem intenção, podem provocar doenças em terceiros. Para evitar cair nessas armadilhas, as rezadeiras dão algumas dicas: para os bebês, portar alguma peça de roupa ou outro adereço na cor vermelha ou, ao receber visitas para o bebê pronunciar três vezes seguidas as palavras "benza deus!" ou "beijo no cu!". Já para afastar mau-olhado dos adultos é recomendado o uso de alguma peça íntima pelo avesso, isso também ajuda a evitar os maus agouros trazidos pela inveja de familiares ou vizinhos.

Os males espirituais que afetam os corpos são muitos, como mal de menino, ventre caído, espinhela caída... Esta última é um tipo de problema na coluna que deixa a pessoa desigual. Para verificar se o enfermo sofre desse mal, a rezadeira toma algumas medidas e faz comparações. Por exemplo, a medida da ponta do dedo mindinho ao cotovelo deve ser igual à distância entre os ombros, e do umbigo ao pescoço deve ser compatível com a circunferência do busto. Caso estas medidas não estejam compatíveis, é necessário rezar para levantar a espinhela, ritual que varia de acordo com as práticas adotadas por cada rezadeira, mas em geral, é feito com arruda ou pinhão roxo. Normalmente, para esse mal específico, a reza deve ser repetida três dias consecutivos para ser eficaz.

Como já mencionei, a maioria das rezadeiras atualmente é composta por mulheres, entretanto, quando meus interlocutores falavam dos rezadores antigos, mencionavam vários homens. Uma grande referência é o Véi Izídio ou Tio Izídio, antigo morador da Passagem Rasa, que repassou sua reza para vários moradores do lugar. Dona Neném Beata, rezadeira que nasceu também na Passagem Rasa, aprendeu, com ele, uma poderosa reza que tem o poder de matar cobras. Sua filha, Ângela, me contou certa vez que quando estava grávida, vinha passando com a mãe por uma vereda, quando foi atacada por uma cobra que, para sua surpresa, deu um bote que quase a vitimou, todavia, sua mãe, que vinha logo atrás, 
estendeu a mão e pronunciou algumas palavras inaudíveis que deixaram a cobra paralisada, estendida ao chão.

Dona Neném gosta de falar sobre suas rezas, mas é bem cautelosa ao abordar o assunto, pois, caso revele as palavras para alguém, sua reza perde a força, assim, limita-se a falar sobre a eficácia de suas curas, mais do que do ritual em si. Ela, como todas as outras rezadeiras que conheci em Almofala, atribui a força de suas rezas à ação de deus e dos encantados, é muito comum ouvir, nos depoimentos das rezadeiras, frases como "eu não curo, quem cura é a fé". Fé em deus e nos encantados, que são - de acordo com elas - os principais agentes dessas curas.

A relação que as rezadeiras estabelecem com os encantados, todavia, é, em muitos casos, bem diferente daquelas estabelecidas por pajés. Muitas rezadeiras não compreendem os caboclos de Umbanda como estando no rol de seres encantados. Ao contrário, dizem ser seres malignos, que não chegam nesse mundo para praticar curas, mas para causar males. Dizem, então, que são auxiliadas nas rezas por seus ancestrais que conheciam os segredos das curas e, por isso, continuam a curar mesmo após a morte. Sobre o assunto, transcrevo abaixo uma conversa travada entre mim, Dona Neném Beata e outras pessoas que participavam da primeira Assembléia do Povo Tremembé, no ano de 2009. Dona Neném nos explicava a diferença entre pajés e macumbeiros.

Dona Neném: Pajé, ele trabalha com a natureza, trabalha com a erva, umas ervas aí que servem pra fazer remédio, sabe? Ele trabalha com a natureza... Ele trabalha com um, com outro... E os encantado também ele sente; o pajé, ele sente a força dos encantado. E o espiritismo, que justamente é o macumbeiro chamam macumbeiro, mas é o espiritismo - ele trabalha com as forças diabólica. (...) é aquela alma que não fica num bom lugar, que vai se encostar naquela outra pessoa. Olha, você sendo uma boa pessoa, um bom espírito, uma boa criatura que você morre e vai pra um bom lugar. Você só vive no mundo pelo consentimento de Deus e pra fazer o bem. Mas se você fez o mal nesse mundo e se muda e vai pra um mau lugar, que você, se voltar pro mundo, você só vem fazer o mal.

Juliana: mas tem pajé que recebe também, né?

Ismael: aquele ali não é o pajé, é o macumbeiro mesmo.

Rosangela: mas o pajé, ele também recebe... 
Dona Neném: o pajé, ele não é pajé, ele é o médico da aldeia. 0 pajé, ele ensina o chá duma malva, ele ensina o chá do hortelã, ele ensina o chá de uma casca de imburana, duma aroeira, esse negócio assim, ele tem força. (...) Os encantados é aquelas pessoa que morrem e fica num bom lugar, aí fica debaixo de um pé de pau, um pau que dê sombra, na beira de uma água, onde tenha água fresca, ele fica ali... (...) Todo Tremembé é entendido, todo Tremembé é sabido ${ }^{31}$, trabalha com vivo, trabalha com morto... (...) É por isso que eu digo, o índio não morre, ele se muda, ele se encanta, aquele índio que trabalhar pro bem, ele se encanta, mas ele volta e vem ajudar aquele que ta ainda na terra a caminhar só pro bem.

Eu gravei o trecho da conversa acima, quando estava realizando a pesquisa de campo do mestrado. Na época, eu andava às voltas na busca de entender tantas categorias de "pajés" que me eram apresentadas pelos membros do grupo. Enquanto Dona Neném assevera, seguramente, que as pessoas que trabalham com incorporação não são pajés, mas sim "macumbeiros", num uso claramente pejorativo do termo, Rosângela - sua filha que é professora indígena e ferrenha defensora das práticas rituais de cura que envolvem incorporação, pois, segundo ela, tais práticas são representativas da "cultura Tremembé" - já faz ponderações e assevera que o pajé também pode receber entidades, ao que é rebatida por outro membro do grupo que, concordando com Dona Neném, também coloca as práticas de incorporação no plano da "macumba". Conversas contraditórias como estas são muito comuns quando tratamos das práticas rituais que envolvem incorporação. Obviamente, nem todos se relacionam com tais práticas da mesma forma. Enquanto são adoradas por alguns, são demonizadas por outros. Todavia, muitos daqueles que, no discurso, recriminam tais práticas, na vida cotidiana, em momentos de aflição, acabam por recorrer aos rituais de incorporação das pajés em busca de cura. Trata-se, portanto, de um cenário pleno de contradições, que envolvem seres humanos, os não humanos e seus diferentes mundos, tendo como mediadores dessas disputas pajés e rezadeiras.

31 É comum usarem-se os termos "entendido", "sabido", ou "quem tem experiência" para se referirem às pessoas que conseguem se comunicar com os encantados. 
Durante as pesquisas de graduação e mestrado, para facilitar minha compreensão e uma possível sistematização de todos esses dados com os quais eu estava a me defrontar, resolvi fechar a análise nos rituais das pajés que trabalhavam com incorporação. Todavia, esta decisão acabou por deixar de fora muitas e importantes questões sobre estes seres e sobre a cosmologia dos Tremembé. É este vácuo que pretendo preencher neste momento.

Todavia, mesmo tendo como prioridade narrativas e práticas rituais das pajés, realizei muitas entrevistas sobre encantados com vários membros do grupo, sobretudo agricultores e pescadores, pois as pessoas que se ocupam dessas tarefas têm um contato muito frequente com as matas e águas de Almofala, os lugares preferidos dos encantados. Entretanto, embora visse nestas narrativas muitas revelações sobre a cosmologia dos Tremembé, não podia aprofundar tais análises por não ser este o escopo da pesquisa em curso naquele momento. Devido ao tempo restrito da pesquisa de mestrado, era mais fácil para mim restringir-me às descrições e práticas rituais das pajés, contudo, nestes trabalhos eu não consegui abranger as diversidades e a amplitude que os encantados têm na vida social dos Tremembé.

Os Tremembé mobilizam frequentemente as noções de natureza e meio ambiente para explicar as relações que estabelecem com os universos encantados. Todavia, o que eles estão de fato anunciando com tais classificações? A natureza seria uma instância oposta ao que as ontologias ocidentais classificariam como sobrenatureza? Pelo que pude observar entre os Tremembé, posso afirmar que não. Os universos apresentados por eles não cabem em polarizações, por isso foi difícil para mim compreender os significados desta natureza ${ }^{32}$ que os Tremembé me

\footnotetext{
32 Joana Oliveira me deu uma importante contribuição para esta questão durante a defesa do relatório de qualificação, na qual ela - que precisou aprender outra língua para trabalhar com os Wajãpi - destacou a dificuldade de se trabalhar com os índios que falam português, no sentido de que as traduções se fazem "automaticamente", quando, no entanto, a tradução operada pelos nativos podem ter sentidos absolutamente diferentes do que se supõe.
} 
apresentavam. Quando os Tremembé me apresentavam os universos encantados, as realidades se multiplicavam, não era o "nosso mundo" versus "o mundo deles", mas de diversos "nós" e diversos "eles" que se punham em relação. A categoria "encantados" engendra uma série de práticas que modelam realidades distintas que ora se cruzam, ora se contrapõem. Este será o mote do próximo capítulo. 


\section{3 "TEM QUE TER CIÊNCIA" - PRODUÇÃo E CIRCULAÇÃo dOS CONHECIMENTOS NA ALMOFALA DOS TREMEMBÉ}

No capítulo anterior, descrevi alguns dos agentes que compõem diversos mundos encantados com os quais me deparei na pesquisa de campo com os Tremembé. Doravante, discorrerei sobre como tais mundos foram, aos poucos, sendo revelados a mim na convivência com o grupo. Durante a pesquisa, meu foco foram as redes de relações tecidas entre humanos e encantados. Ao seguir essas trilhas, desemboquei em mundos onde diversas entidades humanas e não humanas emergem a todo momento, transformando histórias e criando novas agências. As diferentes versões que me foram apresentadas sobre os encantes modelavam planos de existência constituídos por múltiplas agências e agentes sociais.

$\mathrm{Na}$ medida em que fui seguindo as trilhas das manifestações encantadas, pude perceber algumas redes de relações que se formavam entre humanos e outras entidades não humanas em Almofala, especialmente os encantados. Nesse percurso, me deparei com saberes e práticas que modelavam e, assim, multiplicavam as realidades, ou seja, os encantes eram performados de diferentes maneiras. Muitas vezes, as mesmas pessoas que me afirmavam seguramente que os encantados eram "gente", ainda assim, quando se referiam a eles, reafirmavam uma polarização entre nós (humanos) e eles (encantados). Essa diferença também era posta sob os termos "visíveis" e "invisíveis", embora esta invisibilidade não fosse permanente, posto que eles se deixam ver quando Ihes convêm ${ }^{33}$. Em muitas ocasiões, a mesma pessoa vivenciava experiências completamente diferentes com os mundos dos encantes. Estamos diante, portanto, de ontologias múltiplas, as quais revelam diferentes formas de relação com mundos encantados distintos.

\footnotetext{
${ }^{33}$ As noções de invisibilidade ainda serão discutidas neste capítulo.
} 
Para refletir sobre as formas como tais realidades são modeladas nas práticas cotidianas, utilizarei as ferramentas analíticas propostas por Mol (2007) ao analisar o caso da anemia em um hospital de Amsterdã. Ela procura compreender como se concebe a relação entre o real - definido como sendo as condições de possibilidade com que vivemos - e o político, propondo o termo política ontológica para dar conta da forma como objetos são performados na modelação das realidades. Ou seja, a realidade, de acordo com seus argumentos, não é dada a priori, ela não precede as práticas nas quais interagimos com ela, ao contrário, são exatamente tais práticas que modelam as realidades. Numa importante contribuição ao atual debate sobre as relações entre natureza e cultura na antropologia contemporânea, ela segue a trilha proposta pela Teoria Ator Rede nas suas pesquisas sobre práticas médicas nos hospitais de Amsterdã.

Embora o campo de pesquisa da autora seja bem diferente do meu, suas considerações sobre as múltiplas realidades foram essenciais para pensar os universos encantados que a experiência de campo me revelou. Os trabalhos no campo da antropologia da ciência têm descrito o laboratório como um espaço onde a realidade é transformada, pois neles são concebidas novas formas de se fazer a realidade, não se tratam de teorias sobre a realidade, mas de objetos que trazem consigo novas realidades, como vacinas, telefones, novos vírus... enfim uma série de elementos que estão, continuamente, agindo sobre o mundo. Como observa Latour (2012), na Teoria Ator-Rede os não humanos precisam ser atores e não meras projeções simbólicas, sendo que este ator, "da expressão hifenizada 'ator-rede', não é a fonte de um ato e sim o alvo móvel de um amplo conjunto de entidades que enxameiam em sua direção" (p.75).

Partindo dessa proposta analítica, Mol argumenta que, ao forjar novas realidades, alguns objetos levam consigo novas ontologias. Por isso a palavra deve estar no plural, porque sendo a realidade feita, se ela é localizada histórica, cultural e materialmente, ela se torna, assim, múltipla, sendo necessário, também, aplicá-la no plural: realidades múltiplas. A partir desta constatação, a autora elabora críticas contundentes ao 
perspectivismo e ao construtivismo. Sobre o primeiro, ela observa que ele pressupõe a existência de vários sujeitos diferentes, cada qual com suas competências, hábitos e histórias específicos que têm diferentes pontos de vista sobre a realidade, todavia, tal perspectiva não multiplicou a realidade e sim os olhos dos que a veem, os olhares são plurais, mas a realidade continua sendo única. Já o construtivismo, para ela, constitui uma versão na qual poderiam existir várias construções da realidade, mas uma delas se sobrepôs às outras, assim, outra vez, a realidade não se multiplica. Ela propõe, então, que nos afastemos das metáforas da perspectiva e da construção e abracemos outro conjunto que permite compreender as realidades como múltiplas: intervenção e performance, assim, a realidade é feita e performada. Longe de "ser vista por uma diversidade de olhos, mantendo-se intocada no centro, a realidade é manipulada por meio de vários instrumentos, no curso de uma série diferentes de práticas" (p. 06). Para ilustrar sua argumentação, ela recorre à história sobre a anemia, sobre a qual sua pesquisa de campo revelou não haver uma resposta única ou estabilizada sobre o que ela realmente é, mas sim que ela é performada de várias formas diferentes. Ora ela identifica uma performance clínica, quando são observados os sintomas, tais como a cor das pálpebras e os sintomas descritos pelo doente, tais como cansaço ou tonturas; ora uma performance laboratorial, na qual, ainda que não apresente sintomas clínicos, o doente apresenta um baixo nível de hemoglobina, que lhe confere o diagnóstico baseado em teste de sangue que revelam um nível de hemoglobina inferior ao considerado normal em relação à média populacional e, por último, uma performance patofisiológica, na qual o nível de hemoglobina não é suficiente para transportar oxigênio pelo corpo. Continuando sua observação, ela atenta para o fato de que, nos manuais, estas três formas de performar a anemia são descritas como estando relacionadas, todavia, na prática, estas três formas diagnosticam coisas diferentes, já que os objetos de cada uma dessas práticas não se sobrepõem entre si, então se tratam de três formas diferentes de "anemias" que coexistem. Não se tratam de perspectivas diferentes de cada pessoa - 
já que uma mesma pessoa pode passar de uma performance à outra - nem tampouco de construções de um passado na qual apenas uma se sobrepôs, ao contrário, elas surgiram em momentos históricos diferentes e todas elas continuaram coexistindo. Tratam-se, portanto, de realidades múltiplas, que coexistem no presente. Há que se atentar, todavia para as complexas interferências entre os objetos performados. No caso da política ontológica da anemia, não é só a realidade da doença que está em jogo, mas a dos sexos, das faixas etárias e de outras condições pessoais. Assim, é improvável que a política ontológica estabilize, pois as interferências e conexões entre os objetos performados não têm fim, estão sempre em devir. Sendo as realidades múltiplas, elas podem colaborar e/ou depender uma das outras, ou até mesmo colidir entre elas. Outrossim, as realidades podem não só coexistir simplesmente lado a lado, mas também, eventualmente, estar dentro umas das outras.

As considerações de $\mathrm{Mol}$ me ajudaram a pensar nos mundos encantados que os Tremembé me apresentavam para além da dicotomia entre um mundo "terreno" e um "sobrenatural" ou um "mundo dos homens" e "um mundo encantado". A questão não poderia ser descrita a partir destas dualidades porque não são apenas dois mundos que se contrapunham, mas mútiplos mundos que se relacionam entre si.

Inspirada na proposta da autora, resolvi procurar identificar as formas pelas quais os encantados são performados. Nessa busca, analisando os contextos nos quais se desenrolam as manifestações encantadas pude identificar três situações: nos rituais de rezas e incorporações, já descritos no capítulo anterior e sobre os quais não me deterei muito neste; nas lidas com as matas, águas e dunas, já que são esses os lugares preferidos pelos não humanos e dos quais os humanos também dependem para viver e nos eventos políticos do grupo. Os caboclos de Umbanda são apresentados pelas pajés e aqueles que recorrem aos seus rituais como seres encantados que transitam por vários mundos através das linhas e correntes. Já as outras entidades que não baixam nos rituais como o Caipora, o Guajara e as Sereias - moram nas matas e, por isso, se 
esforçam para proteger suas moradas e afastar delas possíveis invasores. Já nos eventos políticos, entidades encantadas, sobretudo ancestrais dos membros do grupo, são invocados para lutar, ao lado dos índios, pela manutenção definitiva das suas terras...

Em cada um desses contextos as relações tanto entre humanos e encantados como entre encantados e outras entidades não humanas guardam especificidades decorrentes das atribuições, das capacidades e das limitações de cada um desses atores. São também apresentados mundos pelos quais tais entidades circulam, não são, portanto, várias perspectivas de uma única realidade, mas realidades que se multiplicam a partir de práticas diferentes. Para compreender as relações entre humanos e encantados é preciso, antes de qualquer coisa, entender os pressupostos que fundamentam as realidades nas quais ambos estão inseridos. Nas diversas versões que me expuseram sobre os encantados, eles estão, impreterivelmente, relacionados ao que chamam de natureza - águas, matas e dunas. Ainda que algumas pessoas tenham me apresentado versões em que eles habitem outras dimensões para além do "mundo terreno"34, quando eles estão no nosso mundo, escolhem "a natureza como morada". Se as áreas onde "há natureza" deixam de existir em determinada área habitada por encantes, eles se mudam, à procura de lugares onde possam viver embaixo de uma árvore, em uma lagoa ou em quaisquer outros lugares que os Tremembé classificam como naturais.

Todavia, do que falam os Tremembé quando remetem a esta categoria? Como é a natureza descrita por eles? Ao investigar tal questão, me deparei com "naturezas" plenas de agências e que - diferente da concepção que pressupõe a existência de uma única "natureza" submetida às vontades humanas, como pensam as ontologias ocidentais transformam a todo instante os cursos dos acontecimentos, fazendo novas realidades. Da mesma forma em que as populações indígenas objetivam o conceito de "cultura", conceitos como "natureza" e "meio ambiente"

${ }^{34}$ Como no depoimento dos caboclos que entrevistei no centro de Seu Chico Brega, por exemplo, exposto no capítulo anterior. 
também tomam conta das pautas das reuniões políticas e das conversas cotidianas entre os índios. É preciso, portanto, compreender a forma como os Tremembé traduzem estas "naturezas", nos seus discursos políticos. A forma como os grupos indígenas vêm refletindo sobre o conceito de natureza tem sido tema de importantes etnografias que buscam compreender as teorias nativas sobre as consequências das ações humanas sobre o planeta.

Optei, portanto, por colocar esta "natureza" posta pelas ontologias ocidentais como algo dado e contraposto à noção de cultura entre aspas. Já a natureza que uso em itálico corresponde à ideia proposta pelos Tremembé de uma natureza plena de agências, onde diversas entidades não humanas vivem em sociedades semelhantes às humanas, composta por elementos visíveis e invisíveis.

\subsection{A natureza encantada dos Tremembé}

Como meu intuito era compreender as relações entre humanos e encantados, tornou-se imprescindível vivenciar os lugares habitados por ambos, e essa foi minha prioridade em campo. Desde o início da pesquisa, meus interlocutores faziam menção a algumas paisagens como sendo moradas de seres encantados, e por isso resolvi focar essa análise nos modos de gestão dessas áreas, pois a preocupação com a degradação dessas moradas foi-me colocada veementemente pelos Tremembé em várias ocasiões. A partir das investigações sobre os lugares, fui percebendo as manifestações encantadas no cotidiano das pessoas e as suas várias implicações sobretudo no que diz respeito às relações estabelecidas com os lugares onde "há natureza". O reino dos encantados é indissociável do que chamam de natureza que, por sua vez - enquanto recintos dos encantes é cheia de segredos e mistérios. Conhecer estes lugares, portanto, é lançarse ao perigo de desvendar os segredos dos encantes. Perigo decorrente do risco de "passar para o outro lado", assim o contato com esses mundos é pleno de prescrições e, acima de tudo, arriscado. Por isso, meus 
interlocutores ressaltavam sempre a necessidade de se manter certos cuidados quando nos encontramos nos recintos onde encantados gostam de estar, como eventos políticos ou quando estamos nas matas, águas e mangues. Estar em lugares que servem de morada aos encantados exige uma atenção maior, é necessário estarmos atentos para os sinais deixados pelos encantes para que possamos compreender as capacidades curativas das plantas, ter sorte nas pescarias e caçadas ${ }^{35}$, ter uma boa colheita na agricultura ou ainda não correr o risco de ser assolados por maus espíritos, como encostos ou sombras. Enfim, são várias precauções que visam fechar o corpo, ou seja, impedir que entidades não humanas possam nos fazer agir à revelia das nossas vontades. Entidades malignas só conseguem assolar pessoas que não tomam precauções para fortalecer o espírito e, consequentemente, manter o corpo fechado. Quando eu andava pelas matas com os Tremembé, as pessoas mais experientes, frequentemente me alertavam sobre a necessidade tomar algumas precauções como me benzer antes de sair de casa e quando passasse por cercas de arame ou encruzilhadas. $O$ ato de se benzer é importante e eficaz para nos mantermos fortes. Sobre o assunto, Dona Mundoca - moradora da Tapera, hoje com mais de 70 anos de idade, me advertiu em relação a isso, aconselhando-me a me benzer sempre que estivesse em lugares como matas, mangues ou lagoas, assim, eu poderia manter o corpo fechado. Esta precaução garantir-me-ia proteção em relação a certos inconvenientes que pudessem, eventualmente, ocorrer em lugares por onde entidades não humanas circulam com frequência. Ela mesma já chegou a escapar de um encosto que "se engraçou" dela quando a viu passar à beira de uma lagoa. Ela e uma amiga vinham de uma farinhada de onde traziam, cada uma, uma cabaça de farinha e goma, quando passaram pela Lagoa Branca, atualmente cercada pela Ducoco. Ao aproximar-se da lagoa, ela - prevenida

35 A caça entre os Tremembé tem se tornado cada vez mais rara, já que as presas têm também rareado progressivamente, muitas espécies, inclusive, estão sob risco de extinção e têm a caça proibida, como a avoante, ave muito consumida e comercializada em todo o Ceará e, cuja caça, há alguns anos têm sido proibida pela órgãos ambientais competentes. 
que era - se benzeu e continuou seu caminho seguida pela amiga. Alguns passos à frente, ela ouviu a companheira gritar "eu quero é tu!", quando ela se virou a amiga, absolutamente transtornada, jogou sua cabaça no chão e partiu para pegá-la, iniciando uma perseguição até a casa da sua sogra, onde, lá chegando, a amiga teve uma síncope que lhe deu tempo para fugir e procurar ajuda. Quando ela acordou do desmaio, ainda possuída pelo espírito, já haviam chegado algumas pessoas que se puseram a tentar negociar com a entidade que, aos poucos, se foi acalmando e explicou que estava passando na beira da lagoa quando sentiu sede e, como não tem corpo e não pôde beber, ficou sentada a olhar a água, lamentando por não poder matar seu desejo. Quando viu as duas moças se aproximarem, quis encostar-se em Dona Mundoca, mas ela - como era mais sabida - tinha fechado o corpo e, por isso, o espírito não conseguiu nela se incorporar, para azar da amiga que, não tendo os mesmos cuidados, não conseguiu se proteger contra ele.

$\mathrm{O}$ acesso a tais mundos e a tudo que faz parte deles, como seus segredos é, portanto, bem restrito, por isso os segredos das propriedades curativas das plantas - para dar um exemplo - são revelados cuidadosa e ocasionalmente, a depender das necessidades cotidianas vivenciadas pelos humanos. Contudo, como veremos, não são todos os humanos que têm merecimento e sabedoria para acessar os segredos inerentes aos encantes. Acessar seus mundos é uma aptidão que nem todos conseguem adquirir, há que se aprender a se relacionar adequadamente com o reino dos encantes, perceber seus sinais e, mais do que isso, reagir a eles de modo a não incomodar os encantados. Embora os pajés consigam ver seres encantados e, assim, ter uma relação bem mais próxima com eles, de afeto e intimidade, como relatei no capítulo passado, outras pessoas, ainda que não os vejam, conseguem perceber tais sinais e aprender com eles sobre as plantas, o solo, as águas, os lugares onde há botijas, entre várias outras coisas. As relações entre humanos e não humanos são, portanto, permeadas por uma pluralidade de sentimentos, afinidades e estranhamentos que passam tanto pelo medo como pelo afeto, mas - de 
um modo ou de outro - desembocam nas formas de conhecer os lugares que habitam. O que pretendo nesta etapa da tese é mostrar como fui percebendo as relações entre humanos e encantados em campo e analisando as implicações delas decorrentes.

Comecei a rascunhar os esboços desta pesquisa no ano de 2011 , após concluída a pesquisa de mestrado, quando retornei a Almofala e apresentei minha pesquisa de mestrado a alguns professores e lideranças. Durante nossas conversas sobre o processo de esbulho de suas terras, os Tremembé ressaltavam veementemente a preocupação com os encantados que, como eles, também estavam vendo suas moradas destruídas pelas ações predatórias que os assolam nas últimas décadas. Foi então que eu percebi que as relações entre índios, encantados e as áreas que ambos dividem entre si precisavam ser consideradas para muito além das narrativas e práticas rituais de cura, fossem rezas ou trabalhos de mesa, mas deveriam ser etnografadas nas minúcias do cotidiano.

Os Tremembé me asseguravam a todo instante que os encantados estavam no centro das disputas territoriais. Considerava, entretanto, que isso não tinha sido levado em conta nos debates antropológicos que abordavam estas disputas na área. Isto porque os encantes têm sido tratados pelos vários pesquisadores que trabalharam com este grupo como "representações" criadas pelos Tremembé para dar plausibilidade às suas experiências cotidianas. Esta era, inclusive, uma das premissas básicas da minha dissertação de mestrado - quando analisei as práticas rituais e as narrativas das pajés - a de que haveria uma dicotomia entre o mundo, que está dado, e uma humanidade que o dota de sentido. Todavia, o desenvolvimento da pesquisa colocou-me diante de mundos que, longe de estarem dados, são plenos de agência e intencionalidade. Ou seja, não são só os humanos que agem sobre o mundo, geram transformações e produzem conhecimento, ao contrário, todas essas atividades só podem ser consideradas a partir das interações entre agências humanas e não humanas. 
Assim, para alcançar o reino dos encante, seria necessário que eu buscasse vivenciar os lugares onde há natureza - lagoas, dunas, mangues e matas -, pois eles eram o principal palco de interação entre agentes humanos e não humanos no cotidiano. A análise desse cotidiano possibilitou-me alcançar de que forma os Tremembé mobilizam os conceitos de "natureza", "meio ambiente" e como explicam os atuais problemas ambientais que assolam a região. Nesse rol de explicações, obviamente, mencionam os empreendimentos levados a cabo pelas indústrias de geração de energia eólica e pelo agronegócio, mas falam também sobre a forma como os humanos acessam o conhecimento sobre a natureza e o põem em circulação. Saber das coisas encantadas é um exercício perigoso que deve ser levado com cuidado e respeito aos encantes.

Quando comecei a pesquisa de doutorado, meu intuito era investigar as manifestações dos encantes fora dos rituais de cura. Assim na ansiedade de ouvir histórias sobre encantados, elaborar estratégias de aproximação, pensar em situações favoráveis a uma possível manifestação deles fora dos centros das pajés - passei a fazer várias visitas domiciliares, entrevistar várias pessoas, numa busca quase frenética. Priorizei os interlocutores que trabalhavam com pesca e agricultura que eram apontados como pessoas mais propensas aos encontros com manifestações encantadas. Confesso, entretanto, que as primeiras semanas foram frustrantes, pois, quando acompanhava as atividades diárias nas matas, lagoas e lagamares, raramente eu ouvia alguma menção aos encantados. Embora meus interlocutores me recomendassem muitas prescrições e cuidados ao entrar nos recintos favoráveis às suas manifestações, como levar fumo para presentear os encantados, evitar fazer muitos barulhos nos matos e estar atenta às suas possíveis manifestações, quando íamos pescar ou passear nas matas, raramente eu os via tomar tais precauções. Isso me inquietava muito, pois eu estava, a todo momento, esperando menções aos encantes. Com o tempo, fui percebendo, entretanto, que tais menções não eram tão explícitas como eu imaginava, por isso eu precisava estar mais atenta a elas. 
Como nas pesquisas de campo que eu havia empreendido até então eu estava acompanhando as práticas das pajés, então era muito fácil o contato com diversas entidades por meio dos rituais. Apreender como se manifestavam os encantados nos rituais não foi muito difícil. Mas, no cotidiano, como se estabeleciam as relações entre esses diferentes mundos? O fato de humanos e encantados dividirem com os vivos alguns lugares de Almofala suscita uma série de questões, já que, para agir e pensar sobre os lugares, os Tremembé precisam se relacionar diretamente com tais entidades, entretanto, essa relação muitas vezes passava despercebida para mim, pois as menções geralmente eram discretas. Às vezes mesmo quando, nas idas às matas, se percebiam alguma manifestação de encantes, isso não era dito claramente. Por exemplo, quando acompanhava a família de Dona Inácia nas pescarias na Passagem Rasa, acontecia de seu filho, Vicente, afastar-se um pouco do resto do grupo e fumar um cigarro feito de fumo artesanal solitária e concentradamente. $\mathrm{O}$ fato me chamou atenção sobretudo porque nunca $\mathrm{O}$ tinha visto fumar, então, quando o indaguei sobre o hábito, ele me explicou que, quando entra em certos lugares, como as matas e águas, é acometido por um forte desejo de fumar, pois nesses lugares, sua coroa fica mais aberta ao chamado dos encantados que, sedentos de fumo, fazem brotar nele tal vontade, pois, assim, ele pode dividir seu fumo com as entidades. Vicente é médium, mas até o momento, não quis desenvolver seu dom, recorrendo de tempos em tempos aos rituais de Umbanda para suspender as correntes. O fumo é muito requisitado pelos encantados. Muitos me recomendavam que, antes de começar uma pescaria, deveríamos deixar um pouco de fumo em algum lugar das matas como presente para o Caipora ou outros moradores das matas, todavia, no cotidiano, poucas vezes vi alguém ter tal preocupação antes de sairmos para as pescarias, este cuidado é mais observado pelos médiuns, que ficam mais sensíveis aos seus sinais e às possíveis retaliações caso não sejam presenteados, pois podem ser acometidos por sintomas como dores no corpo e na cabeça. Não obstante, mesmo as pessoas que não são médiuns, quando chegam 
dos matos com algum desses sintomas também atribuem tais indícios às ações não humanas, geralmente ao Caipora - como castigo por alguma "má conduta" - ou a algum encosto ou outro espírito mal-intencionado.

Assim, com o avançar das investigações, fui percebendo que as menções pelas quais eu estava tão ansiosa, eram muito sutis - gestos, olhares ou arrepios - que se passam muitas vezes despercebidas, que não estão expressas nas narrativas... assim, perceber estas sutilezas exigiu um olhar mais atento a alguns sinais e menções que se faziam a eles no dia-adia. Desta forma, eu teria mais a ganhar registrando o cotidiano do que esperando "algo acontecer" que contemplasse minhas expectativas sobre esses cotidianos. Fui, então, aproveitando melhor o tempo que eu poderia passar nas casas, com as famílias acompanhando suas rotinas.

Privilegiei, assim, o convívio com famílias que tinham um trato mais direto com tais lugares, que descreverei ao longo da tese, mas também acompanhei, na medida do possível, os eventos políticos, como assembleias dos povos Tremembé, ocasiões também propícias às manifestações de agentes não humanos que aparecem tanto para ajudálos nas conquistas políticas, como algumas entidades que se aproveitam da ocasião para perturbar aqueles que estão com o espírito fraco, por não se prepararem para enfrentar as investidas desses agentes.

\subsection{Sistemas de encante: os segredos dos mundos encantados}

As vivências dos Tremembé nas matas de Almofala me revelaram algumas formas de acesso aos segredos dos encantes. Meus interlocutores falam de um sistema de encante, composto por agências e saberes guardados pelos encantados e sobre os quais o acesso é limitado e restrito aos sabidos ou entendidos - pessoas de espírito forte, que conseguem, de alguma forma acessar o universo encantado e captar alguns fragmentos desse complexo sistema.

Ao anunciar suas preocupações com as moradas dos encantados, os Tremembé alertam para os vários riscos decorrentes da possível perda 
de contato entre humanos e não humanos, pois é desse contato, é vivenciando as paisagens que, juntos, os mais diversos agentes que habitam aqueles lugares passam a conhecê-lo. Por isso, um alerta importante levantado por praticamente todos meus interlocutores é o fato de que os contatos entre os humanos e os lugares encantados - a natureza - tem sido cada vez mais esporádico, já que muitas famílias têm abandonado as práticas da agricultura e da pesca tradicionais. Na medida em que avança o processo de urbanização posto em curso na área, as caminhadas por entre as matas também têm perdido espaço para as caminhadas nas estradas recém-abertas, aliás, as próprias caminhadas têm-se tornado mais raras, já que as motos são mais comuns, principalmente se o caminho a percorrer é mais longo. Diante disso, para acompanhar os contatos dos Tremembé com as moradas dos encantados das quais eles tanto falam foi preciso me aproximar mais de algumas famílias que ainda mantem um convívio mais próximo com esses lugares.

Depois de alguns anos de pesquisa na área, já conheço várias pessoas no grupo, assim, não é difícil arranjar hospedagem em quaisquer das localidades, o que facilita muito meu acesso às informações, pois tenho oportunidade de acompanhar muito de perto as rotinas das famílias. Evidentemente, a presença de um hóspede altera sobremaneira a rotina doméstica, mesmo porque meus anfitriões, em geral, me ajudavam bastante na pesquisa. Quando eu reencontrava velhos conhecidos e thes explicava os objetivos da minha atual pesquisa, eles se mostravam interessados em falar sobre os lugares e as ocasiões em que sabiam de manifestações de encantes, dispunham-se a me acompanhar nas casas de pajés ou de pessoas mais velhas que sabiam de histórias dos "tempos antigo", onde estas manifestações eram mais cotidianas. Todavia, por mais que $o$ assunto dominasse a pauta dos meus dias em campo e por mais solícitos que fossem meus interlocutores, os encantes permaneciam para mim como algo praticamente inalcançável fora das práticas rituais das pajés, pois eles sempre se conservavam envoltos a uma atmosfera de mistério e perigo. Mesmo as descrições que revelam alguns detalhes sobre 
o modo de vida e a história de alguns personagens, são sempre rotas e desbotadas, uma vez que os encantados se esforçam para manter os humanos afastados deles e de suas moradas, salvo em raras situações como, por exemplo, nas curas das pajés, quando é possível conversar com eles, muito embora, seja importante lembrar que há muitos seres encantados, como por exemplo o Guajara, o Caipora e as Mães d'Água, não baixam nos terreiros. Excetuando, portanto, os momentos rituais, suas aparições são rápidas, furtivas e provocam assombro aos que as presenciam. Estes contatos são ambíguos e controversos, pois eles se manifestam ora só por sons que produzem nos matos, ora aparecem materializados, ora curam, ora assombram e castigam... como alguns dos lugares mais propensos a manifestações encantadas são as matas e águas, atividades como a pesca e a caça são sempre permeadas pelo risco de se deparar com algum desses entes, por isso meus anfitriões me aconselhavam sempre ir em busca de agricultores e pescadores mais velhos, mormente aqueles que conhecem as propriedades curativas das plantas da região, pois estas pessoas - cada vez mais raras - para conhecer estas propriedades, precisaram acessar os encantes das plantas e, assim, poderiam me fornecer pistas para a investigação sobre tais formas de acesso.

Nas mais diversas narrativas, as chamadas coisas da natureza plantas, águas, rios, etc. - são expostas como coisas encantadas ou como um possível elo entre o nosso mundo e o mundo dos encantados. Quando se referem às propriedades curativas das plantas, por exemplo, se falam que "são encantadas", há que se descobrir o encante de uma determinada planta para saber usá-la. Alguns são descobertos, outros permanecem indeterminadamente em segredo. 


\title{
3.3 "A gente escuta, mas não vê": Estratégias de acesso ao conhecimento
}

As estratégias para acessar tais conhecimentos são muitas. As pajés, para conhecer as propriedades curativas das plantas recorrem a orações que as fazem receber revelações por meio de sonhos, incorporações ou visões, mas só fazem isso em ocasiões especiais, quando elas precisam de algum remédio para curar uma enfermidade qualquer. Dona Maria Bela, por exemplo, quando precisou curar-se de um câncer, rogou aos seus mestres que lhes enviassem uma solução para o problema. Atendendo seu apelo, eles the mandaram uma mensagem em sonho. $\mathrm{Na}$ noite em que fez suas orações, ela sonhou com uma mulher que se apresentou como sua madrinha. Nas suas palavras:

\begin{abstract}
Aí na outra noite eu sonhei com a dita mulher, eu dentro dumas mata e ela também, aí eu me queixei com ela, disse, minha madrinha, me ensine um remédio, pra eu tomar logo! Ela disse 'minha fia, tem uma amiga sua que nunca foi na sua casa, mas agora vai e o remédio que ela lhe ensinar que a primeira letra for um M pode tomar'. Aí no outro dia chegou uma fia ali do (...), ela já morreu, aí disse 'Maria, eu vim lhe ensinar um remédio', eu disse 'o que é, Socorro?', ela disse é o mucum, pode tomar o chá da casca do mucum que você fica boa'. Comecei a tomar, aí sarou.
\end{abstract}

No decorrer da conversa, ela me disse que sua mãe escolheu como madrinha Nossa Senhora da Conceição, a padroeira de Almofala, conforme um hábito comum na região, de escolha de santos católicos como padrinhos e madrinhas de batismo. Ela me explicou ainda que Nossa Senhora também é uma encantada, por isso conhece os segredos das curas e pode repassá-los a quem achar conveniente. Esse conhecimento, contudo, não é revelado somente a pajés, algumas pessoas, mesmo as que não têm o dom de ver encantados, também conseguem perceber os 
encantes da natureza, sejam eles propriedades curativas das plantas ou segredos sobre os caminhos das matas ${ }^{36}$.

O acesso a esse conhecimento é que é a chave da questão. Os encantados vão revelando tais segredos aos poucos, sem pressa, a depender das circunstâncias, das necessidades momentâneas... na conversa transcrita acima, vemos que Nossa Senhora não ensina exatamente qual planta deve ser usada, limita-se a orientar Dona Maria Bela sobre a forma pela qual era poderia chegar a tal planta, por qual caminho, ao que ela deve estar atenta, em que informação ela pode confiar. Esse fato não é raro, as mensagens dos encantados são, como neste caso, enigmáticas, bem como suas demais manifestações.

Algumas pessoas, todavia, estão mais atentas do que a maioria a estes sinais. São os chamados sabidos ou entendidos, pessoas que conhecem a ciência dos encante. Seja porque são médiuns ou seja porque, embora não tenham nascido com a coroa, são pessoas que têm mais habilidade para perceber as manifestações de encantes no cotidiano, nos trabalhos nas matas, caças ou pescarias. Estas pessoas estão mais sensíveis às informações sobre as propriedades das plantas, as curas que elas são capazes de efetuar... elas vão desenvolvendo habilidades através de experiências sensíveis, da vivência cotidiana naquele ambiente que lhes possibilitam um olhar atento aos sinais deixados pelos encantados.

Contudo, ainda que os encantados revelem em alguns momentos seus segredos, este conhecimento nunca será pleno, pois há que se manter uma hierarquia nessa relação. Muitos dos meus interlocutores afirmavam que era vetado aos humanos descobrirem os segredos da natureza, esta, inclusive, é a causa de tantos males que andam a assolar o mundo atualmente. Os humanos estão a querer acessar certas informações que

${ }^{36}$ Como veremos no decorrer do trabalho, os encantados interferem sobre a capacidade humana de se orientar pelos caminhos das matas, mangues e dunas. Quando querem punir ou mesmo só "brincar" com alguém, ele deixa a pessoa ariada, ou seja, desorientada, sem saber qual caminho tomar para voltar para casa. 
não Ihes pertencem, por isso, a natureza está se transformando para, assim, driblar a sede de curiosidade humana.

Esta questão me foi explicada várias vezes, principalmente quando tocávamos no assunto da seca que vem assolando a região desde 2012. É comum, em todo o interior do Ceará, os agricultores realizarem algumas experiências entre os meses de dezembro e janeiro, que thes possibilitam prever se teremos um bom ou mal inverno ${ }^{37}$. Uma das mais conhecidas é a experiência com pedras de sal, geralmente feitas no dia de Santa Luzia, 13 de dezembro. Os agricultores deixam seis pequenas porções de sal grosso alinhadas sobre uma madeira, as seis representam os primeiros meses do ano - de janeiro a junho - semestre de maior ocorrência de chuvas. O resultado é visto no dia seguinte, quando as pedras ficam molhadas pela umidade do ar, assim, as porções molhadas indicam os meses chuvosos. Todavia, nos últimos anos, quando eu perguntava sobre as previsões sobre as chuvas, era-me revelado que suas experiências já não eram mais tão seguras, pois a natureza estava mudando o curso dos fenômenos para não dar vazão à curiosidade humana e manter seus segredos. Não raras vezes, mesmo que eu insistisse em perguntar sobre as experiências sobre as chuvas, os velhos agricultores pareciam desdenhar dos seus próprios saberes, dizendo coisas do tipo "isso lá vale mais nada, quando a gente pensa que sabe alguma coisa, a natureza vem e mudando tudo!". Ou seja, o saber traz consigo responsabilidades e riscos, contudo algumas pessoas querem saber cada vez mais, ignorando os riscos inerentes à sabedoria. Para a grande maioria das pessoas - sobretudo os não índios, que desconsideram a necessidade de respeitar os mistérios dos encantes - a "natureza" está totalmente sujeita às vontades humanas, sempre à disposição das suas vontades e pronta para ser dominada. Em uma conversa com o Cacique João Venâcio, ele observou que "para eles

37 Esclarecendo, aqui, que o termo "inverno" é usado no Ceará para fazer referência à intensidade das chuvas. Se temos uma quadra chuvosa - período que se estende de março a junho - com chuvas intensas, diz-se que se trata de um "bom inverno", caso o período seja de estiagem significa que o inverno foi ruim. 
[referindo-se aos empresários que têm empreendimentos na Terra Indígena], tanto faz! Eles não sabem que existe encantado, que existe nada..." E advertiu que tampouco sabem do risco que correm por estarem desrespeitando os encantes presentes nas matas. Longe de nos mostrar uma natureza inerte, os Tremembé alertam para as artimanhas de uma natureza plena de intencionalidade, que se transforma continuamente, à revelia das experiências e de todo o conhecimento que os humanos possam ter adquirido com ela ao longo dos anos.

Essa afirmativa abre caminho para compreendermos as explicações dos Tremembé sobre os problemas ambientais, entre eles as atuais mudanças climáticas e os desmatamentos. Para os Tremembé, muitas das recentes transformações da natureza - como a seca prolongada que não se deixa prever pelas suas experiências tradicionais - são consequência da forma pela qual lidamos com os saberes. Há que se considerar o mistério como sendo inerente à natureza, portanto nosso saber em relação a ela estará sempre limitado às disposições dos encantes mais que dos humanos. Esta ideia ficava muito evidente para mim, quando abordávamos as mudanças climáticas, assunto muito recorrente nos últimos anos, por conta da longa estiagem que assola a região. Além das explicações relacionadas à exploração os recursos, ao avanço do agronegócio na Área e coisas afins, há uma explicação que vai além de tudo isso, é quando se explicam tais mudanças como sendo consequência da prepotência humana em relação ao saber. Muitas pessoas me explicavam que o ser humano não pode saber mais do que Deus - o criador de tudo, inclusive dos encantados. Atualmente, o ser humano não respeita a hierarquia estabelecida entre si mesmo e Deus, querendo descobrir seus segredos. Por tal razão, a natureza se transformava cotidianamente, frustrando as descobertas humanas.

Para conhecer as coisas da natureza, portanto, é imprescindível o contato com os encantados, ainda que seja arriscado. E, como já explicitei aqui, esse contato é inevitavelmente perigoso, pois se trata da comunicação entre mundos distintos, entre os quais somente poucos entes podem 
transitar. Seu Zé Domingos - importante interlocutor, sobre quem ainda discorrerei bastante nesse texto - me explicou que algumas pessoas morrem, mas, pela sua boa conduta entre os humanos, elas têm privilégio de transitar entre diversos mundos, diferente dos outros mortos, que grosso modo - permanecem no "mundo dos mortos"38, de onde não devem voltar. Os encantados, portanto, conhecem vários mundos e seus respectivos mistérios. Eles conhecem todos os segredos da natureza e aqui permanecem para nos revelar alguns deles. É preciso, porém, ter alguns atributos para perceber tais revelações, como um estar com o espírito forte, ter sabedoria e experiência. Esses são os atributos dos grandes pajés e curadores.

O trecho de uma conversa com o pajé Luís Caboclo ilustra bem a questão dos mistérios inerentes aos encantes e porque eles devem permanecer em segredo:

Quando se fala de encantados, são diversos aspectos, porque nós tem os nossos ancestrais, aqueles que já foram e que ficam tendo um contato. Não um contato pessoal, mas um contato espiritual. A gente tem avisos. A visão é um lado dos encantado, o outro lado chama-se a medicina tradicional que é a medicina das planta que é encantada, ela ta aí no mato, todas essas árvores, todas elas, elas tem um significado, ela cura uma doença, ela tem uma serventia. E é encantada, ninguém sabe. Aí a partir daí é que alguém descobre e começa uma planta medicinal, quando chega uma doença determinada, já sabe qual é a planta, planta fulana de tal, faz o chá, faz o xarope, faz a garrafada, lambedor...

Juliana: mas aí como é que sabe?

Luís Caboclo: é porque é encantado, aí vai descobrindo.

Juliana: porque nem todo mundo tem esse merecimento, né?

Luís Caboclo: pois é, nem todo mundo tem, esse é um lado dos encantado, o outro lado chama-se a experiência da própria natureza que também não é todo mundo que sabe.

Juliana: e quem é esse povo que sabe?

Luís Caboclo: (risos) as pessoas que têm experiência. Antes, agora isso ta ficando em extinção. Antes quando era pr'um jovem casar, uma pessoa queria fazer uma casa, tinha um sabido que ia lá, a pessoa ia lá, "ói, eu quero botar minha casa e quero um lugar bom, que seja sadio", e aí a pessoa ia num certo horário, um horário determinado e dizia "bote aqui! - ele dizia - bote aqui nessa região", "não, mas eu queria mais pra cá", "pra cá não bote, que não dá, é doentio, aqui mora um encantado", porque às vez bota num lugar

${ }^{38}$ Abro aspas aqui porque, como já ressaltei, os mundos dos mortos também são múltiplos, já que várias pessoas me apresentam mundos bem diversos, entretanto como são palavras de Seu Zé Domingos, opto por me manter fiel à narrativa do interlocutor. 
errado, aí ele não vai se dar bem, porque alguém não vai aceitar... Tudo é o lado encantado. Tem o outro lado, o lado da planta, fazer a planta, a terra, o terreno... Isso, no lado da ciência convencional, é o lado do engenheiro, ele vai lá diz o que é bom... Isso é outro lado que a gente não estuda, mas sabe. A água, saber onde a água é boa, onde a água não é boa, tudo é o lado que conhece como encanto que vem através da sabedoria. A biologia, que fala da água, os vento... O tempo tem um contato de encantado. (...)É outro lado que tudo se trata de encantado, tem os espíritos, os espíritos de luz que é o contato dos nossos povos, dos nossos ancestrais, a mata a mata é um encante, também - que, no caso agora, o cara quer fazer uma regressão, se for o caso, aí hoje em dia não pode fazer mais, porque não tem mais mata. Tem que ter a presença da mata. Pra você fazer contato com alguém que ta lá fora, não pode fazer mais, porque você tem que ter no mínimo uma hora, uma hora e meia sem contato com ninguém.

Juliana: pra conseguir ter contato com eles?

Luís Caboclo: pra conseguir ter contato.

Juliana: aí como é que eles se manifestam, seu Luís?

Luís Caboclo: isso é o lado mais... muito experiente desse lado aí, de muita sabedoria, que chama-se vocação. É o lado da vocação. Eu tenho um irmão em São Paulo ou no Rio que ta desaparecido aí no meio do mundo, aí eu quero ver ele, conhecê-lo a qualquer custo e não tem contato nem nenhum conhecimento, aí eu digo "eu vou fazer uma vocação pra descobrir fulano de tal", aí eu tenho que ir pra mata, e aí lá eu vou ter um ponto determinado, uma hora, duas horas, três horas, sem contato com ninguém, que eu vou ficar lá numa posição e vou morrer lá. Meu espírito não fica ali, eu viajo, vou caçar ele. Aonde ele tiver, se ele for vivo, eu fico aparecendo. Pra todo lado que ele se vira eu apareço, aí ele me reconhece e aí fica tendo contato. E aí ele se preocupa, eu faço uma representação lá, ele se preocupa e não tem jeito, "eu tenho que ir na minha terra ver o quê que ta acontecendo, que ta acontecendo alguma coisa... e aí no prazo de quinze dias, ele tem que vir. Isso é um lado encantado também. Agora naquele momento, e chegar uma pessoa, eu tando ali e chegar, "ah, é fulano de tal!", chegar e "fulano! fulano! fulano!", eu to morto, não volto não!

Juliana: se alguém atrapalhar.

Luís Caboclo: se alguém me chamar, falar comigo... só se ver e não falar, mas se falar, eu to morto ali. Não volto mais.

Juliana: perigoso, né, isso?

Luís Caboclo: é, é complicado. Isso é na presença da mata, onde não tenha presença de ninguém. Agora não tem mais, nós não temos mais lugar pra fazer isso. Porque é a vida, quando nós tem as matas, o cabra saía aqui de manhã, andava cinco léguas, se colocava lá no centro, aí ninguém via, passava o dia todinho lá e... (...) O encante, ele tramita na vida da gente. A nossa mente, você, vamos avaliar você, você não é casada?

Juliana: não.

Luís Caboclo: você tem certeza que vai casar e se dar bem? Juliana: não.

Luís Caboclo: a maioria não se dão bem, a sua vida é um encante, você não sabe aonde você vai chegar. É encantado, é outra parte... 
Ou seja, na visão do pajé, "não saber aonde você vai chegar" é uma condição de vida. A vida, de fato, não faria sentido se todos soubéssemos "onde vamos chegar". Isto significa que o segredo é necessário, deve ser respeitado. Por isso os encantados só nos revelam o necessário para curar nossas aflições corriqueiras, e não se deve exigir deles mais do que estão dispostos a revelar, pois há sempre que se respeitar uma instância enigmática que envolve tais seres.

Na narrativa do pajé, a comparação entre o que ele chama de "ciência convencional" e o "encanto que vem da sabedoria" elucida que os Tremembé compreendem o conhecimento sobre os diferentes mundos como algo que só pode ser produzido com os encantados. Não estou afirmando aqui que o conhecimento é transmitido pelos encantados, mas eles próprios são a fonte de tais conhecimentos. A ciência a qual se referem é o próprio encante, que se guarda numa atmosfera de perigosa e misteriosa. São fragmentos desse mistério, no qual os encantados estão envoltos, que vão sendo descobertos pela experiência sensível do contato com o ambiente - formado por elementos e objetos também encantados que proporcionam aos Tremembé terem acesso a este conhecimento. Ora os encantes facilitam este acesso, ora eles dificultam, mantendo os segredos. Na narrativa, o pajé esclarece que os conhecimentos sobre as plantas curativas, por exemplo, são encantados e é preciso, de acordo com a necessidade, desvendá-los. Assim sendo, acessar esse conhecimento é uma tarefa difícil e perigosa, exclusiva dos que se lançam ao risco do contato com estes seres. Nos próximos capítulos, ao falar das disputas pelos lugares onde moram os encantados, detalharei melhor os riscos desse contato, por ora o que pretendo é discutir sobre a produção e circulação desse conhecimento a partir das vivências nas moradas dos encantados. Estes conhecimentos precisam ser construídos cotidianamente, já que a natureza está em constante transformação.

De acordo com Ingold (2000), conhecemos o mundo a partir de uma profunda interação com os diversos organismos que nos cercam, que envolve todos os nossos sentidos. Deste modo, o autor rompe com vários 
dualismos comumente reproduzidos pelas ciências sociais, tais como humano e não humano, natureza e cultura... pois, para ele, o modo de habitar o mundo nos possibilita a aquisição de habilidades que não uma forma de pensar ou de representar o mundo, mas uma forma de ser no mundo. Assim, ele propõe uma ruptura com ideias chave numa certa antropologia, como os conceitos de cultura e representação e propõe um foco nas habilidades adquiridas com o mundo - e não sobre o mundo. Tais considerações são essenciais para pensarmos a forma pela qual os Tremembé conhecem os lugares que habitam - um conhecer que se faz cotidianamente, a cada caminhada, cada pescaria, cada caçada, cada roçado levantado.... Há que se considerar, na análise dos modos de conhecer do grupo, que estes lugares são também habitados por uma pluralidade de outros agentes além dos humanos - animais, espíritos, encantados... - e que todos eles participam desse processo de produção e circulação dos conhecimentos. Muitos dos meus interlocutores, quando falavam das suas caças, destacavam as habilidades e saberes que elas demonstravam sobre o meio. Seu Chico Isídio, morador da Passagem Rasa, em um dos nossos passeios pelas matas da localidade, me mostrava os rastros dos bichos - camaleão, tatupeba, tejo, cassaco - tarefa comum nas nossas caminhadas... Ele me dizia que, da mesma forma como nós humanos - elaboramos estratégias de caça, os animais também o fazem para capturar suas presas, dando o cassaco como exemplo, ele dizia que o bicho tem a ponta do rabo pelada, pois, para capturar os siris e caranguejos - algumas de suas presas favoritas - ele enfia o rabo no buraco do siri e, quando o bicho nele fincava suas pequenas garras, era trazido para fora e devorado. E saltava "os bichos também têm sua ciência!". Ou seja, o termo ciência serve para aludir as formas de conhecer o mundo. Há, pelos relatos que pude colher, vários tipos de ciência. Quando se referem às pessoas que conseguem acessar os mundos dos encantados, comumente se diz que são pessoas que sabem das ciências ocultas, que caracterizam um modo de conhecer que só pode ser alcançado mediante algum tipo de contato 
entidades não humanas, que as ontologias ocidentais classificariam como "sobrenaturais".

Quando iniciei a pesquisa de doutorado na Praia de Almofala, área mais urbanizada da região, as pessoas me aconselhavam procurar os moradores da Passagem Rasa, localidade que, embora tenha também sofrido com o desmatamento que assola a região, ainda guarda muitas áreas de mata, denominadas pelos Tremembé como mata virgem. Minhas experiências nas matas de Almofala eram mais intensas quando lá cheguei ainda na graduação. Quando eu precisava me deslocar da Praia à Varjota ou à Passagem Rasa os percursos eram feitos a pé. Nessa época, as estradas eram mais estreitas, pequenas trilhas abertas na vegetação rasteira do litoral cearense. Como havia menos cercas entre nós e a vegetação, entrávamos muito na mata para pegar frutas como murici, puçá, seriguela e tantas outras que nos amenizavam a fome e a sede sob o sol forte e o calor de aproximadamente 350, característicos da região. Quando iniciei a pesquisa de doutorado, aprendi a lidar de outra forma com esses caminhos, feitos na maioria das vezes de moto, salvo algumas exceções como as idas à Varjota para as quais tenho sempre uma ${ }^{39}$ excelente companheira de viagem a pé - Babi, liderança que mora no Panã e, como tem muitos familiares na Varjota e ao longo do caminho até lá, sempre se dispunha a me guiar nesse caminho, acompanhada de seu marido Zé Flávio. Mas, salvo as agradáveis caminhadas com Babi no rumo da Varjota, a maioria meus trajetos entre as localidades atualmente são feitos de moto, destarte, passei a acompanhar mais de perto outras atividades que me proporcionariam um contato mais direto com esses lugares. As estadias na Passagem Rasa foram muito produtivas nesse sentido porque passei a acompanhar uma família de pescadoras $^{40}$, a família de Dona Inácia,

\footnotetext{
39 Localidade próxima à Praia de Almofala.

40 As mulheres, em geral, não participam das atividades da pesca em alto mar, sendo esta uma tarefa masculina. Confesso que, algumas vezes fui convidada para acompanhar as despescas dos currais de peixes - armadilhas submersas, feitas com estacas e arames que não ficam muito longe da margem, todavia, o medo de enfrentar o mar me impediu de aceitar os convites, mesmo porque não sei nadar muito bem. As informações que tenho sobre a pesca marítima foram adquiridas, portanto, por depoimentos de pescadores e pela
} 
rezadeira e parteira da localidade, recentemente falecida. Nos dias que passei na Passagem Rasa, costumava ficar a maior parte do tempo na casa de Dona Inácia ou de seu filho, Vicente, diretor da escola indígena da localidade. Conheci Vicente desde as minhas primeiras viagens a Almofala, na época, ele frequentava muito a região da Praia e era muito próximo à família da Dijé, então desde as primeiras vezes que visitei a localidade, costumava ficar na sua casa, nessa época, ele ainda morava com a mãe. Como sempre mostrei interesse em saber histórias sobre encantados, Dona Inácia era uma grande referência apontada por muitos interlocutores como alguém que poderia me falar muito sobre os encantes, já que, sendo rezadeira, conhecia muitos segredos sobre os mundos encantados. Sua casa foi construída por seu filho, morto há aproximadamente vinte anos. Ele trabalhava em uma olaria nas proximidades de sua casa e construiu, artesanalmente, cada tijolo da pequena casinha de quatro cômodos. Em memória do filho, ela mantem a casa exatamente como o filho a construiu e reluta sempre que alguém propõe reformá-la ou mesmo fazer pequenos reparos. Há alguns anos, um forte inverno destruiu grande parte do telhado e a obrigou a concordar em retelhar a parte da frente, embora, conforme ela me confessou, esta tenha sido uma tarefa muito dolorosa para ela. Seu cercado não é muito diferente dos demais, nele, além de sua casa, há também a casa de uma filha, algumas hortas e um galinheiro. Quase sempre, para comemorar minha chegada, ela matava uma galinha que ela cozida no seu fogo a lenha e temperada com alguns dos artigos de sua horta, como cebola e cheiro verde. Como sua cozinha é bem pequena, ela construiu um pequeno cômodo atrás da casa para abrigar o fogão a lenha. No terreiro, há as habituais tucuns armadas em baixo de uma frondosa mangueira, cujas folhas caídas eram varridas diariamente. Apesar da sua idade, ela cumpria tarefas domésticas que exigiam bastante esforço, sempre que necessário ia buscar lenha nas matas, que ela carregava na cabeça com peculiar habilidade. Quando eu me mostrava admirada com

leitura da etnografia de Oliveira Jr. (2010), que descreve com preciosidade a atividade da pesca entre os Tremembé. 
seus árduos trabalhos diários, ela se lamentava de não poder mais realizar todas as tarefas que sempre fazia habitualmente quando era mais jovem.

Sempre que conversávamos sobre os encantes, ela falava deles como algo cotidiano, em suas andanças quase diárias pelas matas do lugar, dizia estar sempre atenta às manifestações de entidades encantadas, especialmente o Caipora, que mora nas matas, de onde ela tira as ervas usadas nas suas atividades curativas como rezadeira. Sua filha, Hosana, sempre pesca junto com seus filhos pequenos e uma vizinha que costuma acompanhá-la, Fátima. Começávamos a pescaria bem cedo para pescar nos lagamares - pequenos riachos nos quais se pescam várias espécies de peixes e crustáceos, como diferentes tipos de camarão, siris, caranguejos e búzios. Saíamos para pescar por volta das sete ou oito horas da manhã e, na volta, já perto do meio dia, após o preparo e consumo dos alimentos, deitávamos nas redes armadas embaixo das mangueiras que tomam conta do terreiro de Dona Inácia, tão bem varrido e cuidado diariamente e esperávamos seu cafezinho da tarde, acompanhado quase sempre de tapioca ou batata doce, plantadas nos arredores de sua casa, por filhas ou genros. Durante esse intervalo, Dona Inácia contava-nos, a mim e às filhas e netos também presentes sobre muitas histórias, todavia, como meu assunto favorito eram os encantes, eles acabavam por dominar nossos debates. Sendo rezadeira, ela conhecia profundamente as propriedades das plantas da região e, vez por outra, ela precisava adentrar nos matos em busca de ervas ou seivas usadas nas suas garrafadas (infusões), chás ou banhos. Ela me alertava que essas idas às matas eram perigosas, pois estes lugares são habitados por muitos seres não humanos que podem fazer muitos benefícios, mas também malefícios ou mesmo brincadeiras de mal gosto, sobre isso, contava - sempre aos risos - as vezes que o Caipora a havia ariado nos matos. Na última vez, já recentemente, havia ido coletar um pouco de almesca, seiva utilizada por ela como incenso nas suas rezas com bebês, e - embora tivesse trilhado um caminho habitual, no caminho de volta para casa, ela não conseguiu se orientar, permanecendo perdida por uma manhã inteira, até que acompanhou a extensão de uma cerca de 
arame que a levou para uma estrada onde havia várias casas de pessoas conhecidas e, só então, ela pôde ver o quando havia andado sem se dar conta na direção oposta à sua casa. Ela explicava então que, quando adentramos nas matas desatentas ou com o espírito fraco, ficamos sujeitos às ações dos moradores das matas e diversas outras entidades que podem agir de diferentes formas. O Caipora, por exemplo, quando quer se divertir às custas dos humanos, é capaz de deixá-los perdidos mesmo em meio a caminhos que percorrem todos os dias e conhecem profundamente. Dona Inácia explicava-me que ele podia tanto mudar as coisas de lugar - árvores, veredas... - como provocar uma confusão na cabeça das pessoas as fazendo perder momentaneamente a memória sobre aqueles lugares.

As relações estabelecidas entre as mais diversas entidades que habitam Almofala - humanos e não humanos - são essenciais, portanto, para que humanos possam conhecer e desenvolver as habilidades mais básicas na lida com aqueles lugares. Ainda na comunidade da Passagem Rasa, dois interlocutores foram essenciais para minha pesquisa, Seu Zé Domingos e seu filho, Manuel, duas lideranças do Movimento Indígena e profundos conhecedores das matas locais. Em muitas dessas caminhadas, eles me diziam que descobrem as propriedades curativas das plantas através da experiência, isto é, pelo olhar, pelo cheiro, pelo tato, pela textura, pela forma, pela cor... E assim, experimentando as plantas com todos seus sentidos, eles vão deduzindo a sua serventia. Através da experiência sensível eles adquiriam ciência, ou seja, passava a conhecer alguns dos segredos da flora e da fauna local. A vivência no ambiente de Almofala, permitir-lhes-ia conhecer um pouco das ciências ocultas ou ciência dos encante.

Seu Zé Domingos me deu muitos elementos para refletir sobre as formas de acesso a tal ciência. Certo dia, ao mostrar-me um talho que havia aberto no dedo quando abria um coco para dar de comer às galinhas, contou que, logo quando ocorreu o acidente, ele tomou o rumo de casa para apanhar um remédio muito usado por ele como cicatrizante, feito a partir de uma fruta muito comum na região - o batiputá (Ouratea floribunda). 
Porém, como o caminho não era tão curto, ele foi buscando, entre as árvores com as quais se deparava, algum remédio para estancar o sangue. $\mathrm{Na}$ ansiedade de dar logo uma solução ao sangramento, ele experimentou a primeira árvore que lhe veio à cabeça: um pé de torém. Raspou-lhe a casca e pôs o pó sobre o sangramento que, não apresentando qualquer melhora, continuou a jorrar. Foi quando ele percebeu que não poderia resolver sozinho seu problema e precisava recorrer à sabedoria dos encantados. Nesse momento, ele se concentrou e pediu sabedoria para resolver seu problema naquele instante. Depois disso, resolveu experimentar, dentre as tantas árvores que havia no lugar, um pé de almesca, cuja raspa da casca fez parar o sangue instantaneamente. Ele assegura que foram os encantados que, compadecidos da sua aflição, o guiaram até a árvore que Ihe serviria de remédio. Ainda que Seu Zé conhecesse a árvore desde criança, ele não sabia da serventia dela para cicatrização ou coagulação, foi naquele instante, diante da necessidade que se impôs a ele, que pôde acessar tal conhecimento. Ele alcançou essa dádiva graças às suas habilidades de perceber os sinais dos encantes.

Esse fato, suscitou várias questões sobre a produção de conhecimento entre os Tremembé. De que modo Seu Zé Domingos conseguiu descobrir seu remédio logo na segunda tentativa em meio a tantas árvores que o rodeavam? Quais suas estratégias para alcançar esse universo encantado em alguns instantes? Qual pressuposto sustenta a ideia defendida por ele de que esse conhecimento ser-lhe-ia indicado por um encantado?

Movido por questões semelhantes, Almeida (2013) levanta importantes reflexões sobre a pressuposição da existência de entes não humanos. Ele toma ontologia como sendo "o acervo de pressupostos sobre o que existe" (p. 03). Essa pressuposição, entretanto, não necessariamente está fundamentada em um encontro efetivo, pois "pressupostos ontológicos dão sentido, ou permitem interpretar, encontros pragmáticos, mas vão além de qualquer encontro particular" (p. 03), assim, eles não são elimiváveis por experimentos. A pressuposição da existência do peixe na 
água, para usar o exemplo do autor, é também a pressuposição da existência de todos os outros entes a ele relacionados, como a mãe dos peixes com suas aldeias subaquáticas.

Os atuais estudos que abordam a noção de ontologia estão classificados, segundo Marres (apud Souza, 2015), em dois níveis de reflexão: o primeiro, ocupa-se com os pressupostos metateóricos sobre as entidades que compõem a realidade e as relações entre elas. Ou seja, propõe compreender não a forma como dotamos o mundo - o real, o dado - de sentido, mas compreender este mundo enquanto múltiplas realidades povoadas por diversas subjetividades. O segundo, que ela chama de "ontologia empírica" - que tem abrange as propostas de Latour, Stengers e Mol - consiste em deslocar o olhar para as práticas a partir das quais surgem novos agentes sociais. Não se trata, portanto, como na ontologia clássica, de focar a análise na essência dos seres, mas de entender as associações através das quais diferentes entidades vêm a ser no mundo. A realidade não antecede as práticas, como usualmente a concebemos, mas é moldada por elas numa gama de associações infinitas que as transformam cotidianamente. É exatamente isso que busco nesta pesquisa, focar a análise não nos "seres" encantados, mas nas formas de associações estabelecidas entre as mais diversas entidades aqui expostas - humanos e não humanos - e sobre como estas associações criam e recriam realidades a todo instante.

Outra revelação que o episódio narrado por Seu Zé Domingos nos traz é o fato de que o acesso ao conhecimento é uma experiência que mobiliza não só todos os sentidos na percepção do ambiente, o que inclui a capacidade de cada um em perceber a agência dos encantados. Esta percepção só se torna possível na relação com o ambiente. Portanto, as relações do sujeito com tudo que o cerca não podem ser apreendidas de maneira dualista como um ser que simplesmente cria representações acerca do mundo ao seu redor, ao contrário, as coisas do mundo interagem num movimento contínuo e recíproco e é essa interação que constitui a vida social (Ingold, 2000). 
A análise das narrativas e das relações estabelecidas entre humanos e encantados descortinam a forma de interação entre os Tremembé e o ambiente que os cerca. Um ambiente cheio de encantes, surpresas, perigos... estar em contato com encantados é sempre - como os casos aqui expostos mostram - um grande risco. Várias são as histórias de pescadores ou caçadores que, descuidados, foram encantados por entidades com as quais eles se depararam nas suas rotinas de trabalho. A reação que quase todos têm a qualquer sinal da presença dos encantados é evitar o encontro, como o exemplo da história abaixo, contada por Manuel:

Eu saí aqui, pra tirar umas vara pra fazer essa porteira ali. Isso era meio dia, bem meiodião! Eu pulei aqui o arame e saí pra lá pro mato, aí eu peguei a vareda, peguei a varedinha vindo de lá. eu digo, 'eu vou tirar aqui bem no pé da vareda as vara que é pra ficar fácil, né, d'eu botar pra fora, que elas tando bem no pézim da vareda..., Aí eu fui e tirei as vara. Comecei a tirar, de cabeça baixa aqui, tirando, tirando, já tinha torado assim bem umas cinco ou seis, de cabeça baixa aqui bem no pézim da vareda, no pézim da vareda... Aí quando eu escutei bater assim pra frente, bater vindo de lá pra cá. Como que fosse uma pessoa vindo de lá pra cá por dentro do mato. Dentro do mato, andando na vareda por dentro do mato, batendo no mato, de lá pra cá, aí eu maginei até assim 'é gente que tem ali no mato tirando pau também', que aí nesse mato aí a negada tiram vara, o que precisa, eles tiram aí no mato, né? Aí eu digo, 'é gente que ta tirando vara'... eu imaginei que era um senhor que tem ali que ele tava fazendo uma casinha de taipa e eu imaginei que era ele que tava tirando vara também pro mode envaroar as parede, né? Aí eu também não me importei, eu escutei aquela zoada e também não me importei, eu digo 'é o véi que ta ali tirando vara também', aí fiquei... aí eu fui e disse assim 'tendo gente de lá pra cá na vareda, ele vai passar bem aqui onde eu to, aqui no pé... aí fiquei ali tirando vara e vinha de lá pra cá essa zoada (...) aí eu sei que eu esperei né? fiquei ali tirando vara, tirei o tanto das vara que eu ia tirar, aí quando chegou assim bem perto de mim, aí calou. aquele jeito daquela pessoa que vinha de lá pra cá no mato calou. Aí calou, eu tirei as vara, botei num monte (...) quando eu cheguei lá, onde tinha parado a zoada, quando eu olhei o rastro no chão, se tinha rastro de alguém, se era gente mesmo que vinha de lá pra cá, se tinha rastro de alguém lá por onde tinha parado a zoada, aí eu olhei prum lado, olhei pro outro, que lá é assim meio limpo [referindo-se ao chão de areia branca de praia, no lugar por ele especificado não havia muitos arbustos] reparei o rastro, se tinha rastro de alguém, se não tinha... Aí eu não vi rastro de ninguém, não vi rastro de ninguém. Aí eu digo "rapaz, mas que zoada era aquela no mato, que parecia gente e não era ninguém?" Também eu imaginei logo "isso aí só pode ser alguma coisa". Também eu vim de lá pra cá ligeiro, peguei meu feixe de vara, botei no ombro, vim 
m'embora e lá ficou [risos] depois eu imaginei logo, 'isso aí só pode ser os encantado, a visão logo do mato aí". Tem muita... tem muita... essas coisa aparecem...

Durante os últimos meses de campo, Manuel e seu pai, Seu Zé Domingos, com paciência me explicaram a lida com os roçados, as propriedades das plantas, falaram sobre a diversidade da fauna e da flora da região e me contaram muitas histórias de encantados. Isto porque, como trabalham na agricultura e na pesca, estão frequentemente em lugares onde encantes costumam se manifestar, então tal contato é inevitável. Na sequência da conversa acima, Manuel conta sobre um dia em que estava pescando com choque ${ }^{41}$ e conseguiu prender uma grande traíra dentro da armadilha, porém, quando foi tirá-la de dentro, ela desapareceu. Ele explica que se tratava da Mãe d'Água que se transformara em traíra para assustálo e afastá-lo de suas moradas.

As caminhadas com Seu Zé Domingos, como já mencionei, eram especialmente produtivas para conceber a relação entre humanos e não humanos na produção desse conhecimento. Ele ia mostrando frutas nativas, plantas que serviam para cura ou para a fabricação de utensílios - como o tucum, do qual se fazem redes e cordas - e também lugares onde ele já havia se deparado com sinais deixados pelos encantados... segundo ele, os encantados são seres que não podem ser vistos, somente ouvidos, conforme o depoimento a seguir:

Aí é antigo, desde o meu conhecimento de menino, que vem vindo... A gente escuta, mas não vê. A gente às vez se espanta, quem já sabe aí nem se preocupa, mas a pessoa que não sabe, vendo aí fica assanhado... É que nem o assobieiro, o assobieiro, eu não sei na cidade, mas aqui pelo mato, nos meses do inverno, quando ta no inverno, não é toda noite, mas a gente escuta muito o assobio dele. É uma coisa que não tem quem diga o que é. A gente escuta, mas não vê, eu pelo menos, eu nunca vi não, escutar eu escuto, mas vê não... É sistema de encante. Sistema de encante, é... É as coisa que a gente tem aquele sentido que existe, mas ninguém nunca encontra, é assim como que seja... Encantado, que tem o nome, mas ninguém nunca acha o dono. Porque tem o dizer assim, "tudo o que tem nome tem o dono, o menos o segredo do encante". É como o segredo da natureza. Aqui em riba da face da terra, não

${ }^{41}$ Armadilha para pesca feita artesanalmente com varas e cordão de tucum. 
existe um sabido pro mode ele me dizer o significado do segredo da natureza, pode fazer o que fizer, mas não tem... Tem aquela história dos cientista, que vai acontecer... Às vez quando acontece, mas eles erram, que nunca é uma coisa certa. A natureza, ela faz e desfaz. Você já percebeu isso?

Como podemos perceber, ele articula o termo natureza com o poder dos encantados. O sistema de encante é a própria ação daquilo que ele chama de natureza. Em muitas das nossas caminhadas pelas matas, quando me mostrava alguma planta e falava sobre suas propriedades curativas, ele repetia "na natureza tudo é encantado!". E quando eu perguntava se alguma planta tinha o poder de curar, ele nunca dizia "não". As plantas cuja propriedade curativa era conhecida por ele, ele falava sobre, quando não, ele afirmava que "o encante dessa planta ainda não foi descoberto", ou seja, toda planta carrega em si uma capacidade de cura que constitui o seu encante. Por isso os encantados, por vivenciarem e conhecerem outros mundos, sabem de coisas que, para nós - que não vivenciamos esses mundos - é e continuará sendo um grande mistério. ${ }^{42}$

\title{
3.4 A atuação dos encantes nos eventos políticos
}

\author{
O discurso do pajé Luís Caboclo na I Assembleia do Povo
} Tremembé, em 2009, também nos ajuda a compreender melhor a questão:

\begin{abstract}
Este sol que ilumina, ele tem um poder tão grande que (...) só ele clareia o mundo, clareia tudo enquanto, ele pode clarear a cabeça de todos nós. Ele tem uma sabedoria tão grande, ele tem uma rapidez, uma velocidade, que a gente não percebe. Você pega um avião e você viaja o dia todinho e não atravessa o Brasil se for o caso, e ele anda muito rápido. E o sol todo dia atravessa o mundo, bem devagarzinho, ninguém vê ele se mover e todo dia ele atravessa. Ele se impõe aos avião, com tanta velocidade e ficam no meio do caminho, é uma rapidez... É conforme a rotação e aí ele faz aquela globalização todinha. Isso é muito complicado. Por conta
\end{abstract}

42 Outro caso etnografado na Amazônia indígena que tem me ajudado bastante a refletir sobre o conhecimento os Tremembé acerca das plantas e suas classificações é o de Oliveira (2012), no qual a autora analisa os saberes e enunciados dos Waiãpi sobre as plantas, no intuito de alcançar como os membros do grupo se relacionam com o ambiente da floresta e os seres que a compõem. 
disso, ele é muito perigoso, porque ele convive o mundo inteiro, ele não convive só aqui em nós não, ele vive todos e todas, ele clareia tudo! E isso é muito com, isso faz parte da cura, faz parte de tudo. A medicina tradicional, as árvore, elas têm um poder de espírito que é muito grande, e faz parte do lado espiritual, porque elas, porque elas são viva. Os espírito (...) a maioria, eles vive debaixo das árvore, eles procuram as árvore. (...) Eu não sei ler, não sei nada, mas eu aprendo com o tempo, ele é que é professor de todo mundo, além da visão que a gente tem, a gente aprende. Eu vi uma frase aqui (...) lá na Tapera, 'tão brocando o mato, aí disse que ta aparecendo lá uma frase, que diz que é uma voz, uma coisa... Não sei se é os menino inventado, mas mesmo sendo inventando, tem lenda que elas são muito produtivas, elas são verdadeira. (...)Se uma voz fala dizendo que "tão tomando meu espaço e eu moro aqui e eu quero viver aqui..." e aquela coisa... E essa voz fala e ninguém vê nada que fica assim, um tipo duma assombração. Os espírito, eles têm o lugar de morar, o lugar de viver. Agora com a civilização, com a tirada das mata, é que isso acabou, mas antes... Não sei se em todas as aldeias tinha, mas os Tremembé com certeza tinha. E a gente conhece esse segredo. Quando era pra botar uma casa, ia lá uma pessoa determinada ou uma pessoa que tivesse conhecimento e aí praquela pessoa dar o lugar da casa. "Eu queria botar nesse continente aqui, mas eu queria que você desse o lugar pra eu botar", e aí aquela pessoa sai, vai lá num horário da noite, e aí correge aquela área, e aí, com a continuidade, uns se regalam pelo calor da terra, aquele movimento, aí ficava ali naquele movimento sozinho, aí dizia "o lugar da casa é aqui. Aqui não pode, aqui não pode, pode aqui", "não, mas eu queria aqui", "se você botar aí, aí é doentio aí não dá, não pode, aqui você não vai se dar bem, porque você não vai ter muita felicidade, bote aqui!" e era lá o lugar. (...) aí não era mais o silêncio que dizia, era as árvore que dizia. As árvore diziam onde era pra botar, que tem tudo a ver com a ciência. (...) às vez a pessoa diz assim 'fulano só véve doente, a família toda doente, é um azar e tal...' Tem tudo a ver com o local que você mora. (...) Existe uma lenda que diz assim "Te mudas de região, que tu mudarás de posição!"

As narrativas acima nos dão pistas sobre o que exatamente os Tremembé falam quando articulam o termo natureza. Conforme o pajé, há uma ciência dos encantados que movimenta o mundo. Até então, os trabalhos produzidos sobre os Tremembé - inclusive o meu, no mestrado consideravam os encantados como seres que controlavam ou regiam as "forças da natureza". É o que dizem muitas das narrativas colhidas entre os Tremembé. Entretanto, não se leva em conta se aquilo que eles chamam de "natureza" é o mesmo que nós chamamos. Com base nos dados etnográficos aqui expostos, sugiro que não.

Inicialmente, eu partia da hipótese de que através da análise das narrativas, eu poderia compreender a noção de natureza e sobrenatureza 
para os Tremembé. Ao tentar descrever o "lugar" dessa instância sobrenatural na cosmologia Tremembé, eu pensava, num primeiro momento, em usar o termo "realidade paralela", todavia, embora algumas narrativas afirmassem categoricamente que os encantados viviam em outra dimensão, um mundo que a cosmologia ocidental classificaria como "sobrenatural", outras diziam que se tratavam de seres das matas que dividiam com os humanos os mesmos lugares. Havia ainda interlocutores que me asseguravam que tudo na natureza é encantado, por isso nós nunca conseguiremos dominá-la, pois o mistério é algo inerente ao universo encantado, ele só se torna visível a algumas poucas pessoas.

Portanto, o que as minhas investidas em campo revelaram é que estas dimensões não estão propriamente separadas. Os encantados não estão "fora" da "natureza" - em uma instância "sobrenatural" - protegendo e cuidando de seus recursos. Os elementos que classificamos como "naturais" - águas, matas, pedras e dunas etc. - são, eles próprios, encantados. Eles portam em si mesmos uma capacidade de encante, por isso defendo aqui a ideia de que não podemos concebê-los como mediadores, mas como agentes. Antes de concebê-los como seres ou entidades que atuam na mediação entre os humanos e a natureza, devemos encará-los como as agências que movem o mundo e constituem as realidades.

Esta constatação mudou os rumos da minha pesquisa, já que eu estava interessada em compreender as noções de natureza e sobrenatureza para os Tremembé, entretanto, mesmo que eu procurasse quebrar algumas dicotomias postas quando falamos dessas duas instâncias, ainda assim, acabava por polarizar o "mundo dos encantes" como estando em oposição ao "mundo dos humanos". Seguindo essa lógica de pensamento, eu não encontrava termos que pudessem traduzir o "lugar" dos encantes na cosmologia Tremembé. No início das minhas reflexões, falar dos mundos encantados foi uma grande dificuldade, pois observei que não poderia tratálos como estando em uma instância sobrenatural, posto que muitos interlocutores me afirmavam seguramente que eles dividiam com os 
humanos os mesmos lugares, assim pensei em usar o termo "realidade paralela", todavia percebi que tal termo também não traduzia os mundos encantados, pois eu não estava diante de duas realidades, mas de várias.

As leituras de etnografias que abordavam as noções de natureza e sobrenatureza em outros grupos e contextos foram muito elucidativas para o amadurecimento das questões aqui levantadas. Uma interessante investigação foi empreendida por Cometti (2015) entre os Q'eros, nos andes peruanos, na qual o autor busca compreender as representações sobre as mudanças climáticas. Ele ressalta que estas mudanças não seriam somente mudanças "físicas", mas também "um objeto cultural". Entretanto, todas as discussões, as políticas públicas e os acordos elaborados para tentar solucionar ou mitigar o problema das mudanças climáticas e das migrações por elas ocasionadas baseiam-se na ontologia ocidental, fincada na polarização entre natureza e cultura, que aponta o problema como sendo puramente "físico", ocasionado pela interferência do ser humano no curso da biosfera, deixando as questões "culturais" relacionadas ao tema, em segundo plano. Coloca-se, assim, as mudanças climáticas na esfera "natural", enquanto as migrações estariam no plano "cultural". Ele mobiliza então três conceitos para nos ajudar a compreender como os Q'eros veem as mudanças climáticas: percepção, interpretação e relação. Cometti busca compreender como os sujeitos da pesquisa percebem e interpretam o discurso ocidental sobre as transformações no clima. Todavia, ele chama atenção para o fato de que esta compreensão só é possível se, antes, compreendermos como os Q'eros se relacionam com elementos não humanos, como a chuva, a neve, os animais e as plantas. Estariam estes elementos, assim como na visão ocidental aponta, no plano da "natureza"? Ao analisar os discursos e as práticas dos seus interlocutores em campo, 0 autor mostra que estes elementos são prenhes de intencionalidade. Um dado etnográfico explorado pelo autor é a história de um xamã que se comunica com o nevoeiro, mostrando que os fenômenos atmosféricos - que, na classificação ocidental, seriam "naturais" - na ontologia Q'eros seriam dotados de agência. 
Não obstante eu considere que a abordagem proposta por Cometti está muito presa à ideia de representação, suas questões sobre as noções de natureza, cultura e, mais ainda, sobrenatureza entre os Q'eros ajudaram-me a refletir sobre o caso por mim estudado entre os Tremembé. Ele conclui que os Q'eros não estabelecem uma ruptura entre naturezacultura-sobrenatureza, mas uma continuidade. Assim, não haveria, para eles, uma instância sobrenatural, já que entidades não humanas - que as ontologias naturalistas colocariam no plano da sobrenatureza - estariam no mesmo "mundo" dos humanos.

No intuito de aprofundar minhas reflexões sobre as relações entre agentes humanos e não humanos na antropologia, procurei atualizar algumas leituras sobre o conceito de cosmopolítica, que conheci através das produções de Sztutman (2005), em Sobre a ação xamânica, artigo no qual o autor busca seguir as redes de comunicação nas Guianas e na Amazônia, situadas em um espaço que ele denomina - apoiando-se em reflexões postas por Latour (1994) e Viveiros de Castro (1998 e 2000) - de cosmopolítico, posto que "irredutível a um domínio exclusivamente humano (...) dada a inflexão, a todo momento, a um plano cósmico - plano microscópico ou invisível das relações com agentes sobrenaturais povoado por subjetividades díspares" (p. 151). Ele faz um escrutínio sobre as análises em torno da ação xamânica nas populações guianenses, demostrando que o xamanismo serve como via de acesso às noções que estas populações têm a respeito do "outro mundo" ou da "sobrenatureza" (termos que o próprio autor utiliza entre aspas).

As reflexões do autor sobre uma política cósmica, na qual interagiam agentes humanos e não humanos contribuíram demasiadamente para as minhas análises sobre os dados coletados em Almofala, contudo, quando eu pensava na configuração dessa arena cosmopolítica entre os Tremembé e os encantes, eu não me via diante da comunicação entre diversas entidades que transitavam entre dois mundos distintos, mas de uma pluralidade de versões sobre as agências encantadas 
que alcançavam diversos mundos e me apresentavam uma pluralidade de ontologias.

\subsection{Circulação de conhecimentos}

As diversas agências que permeiam esses mundos vão formando redes de relações no quais os conhecimentos são postos em circulação. Ou seja, a produção e circulação desses conhecimentos se fazem nas relações. Conforme exposto nos dados de campo aqui apresentados, nas mais diversas relações que são estabelecidas com os encantes, há uma troca de experiências que denotam não só as formas como os conhecimentos são produzidos, mas também as regras através das quais eles são postos em circulação. Nem tudo aquilo que se descobre sobre os encantes pode ser posto em circulação. Muitas vezes, quando estava gravando conversas com meus interlocutores, eles pediam para desligar o gravador e me contavam coisas com a condição de ficarem guardadas em segredo, tais como a localização de lugares encantados, descrições sobre as moradas dos encantados - castelos ou casas que se tornam visíveis apenas para alguns -, descrições sobre a vida social dos mesmos, sobre o que acontece conosco após a morte ou ainda sobre a propriedade curativa de alguma planta... São segredos que os encantados revelam circunstancialmente, mas que não podem circular livremente porque abrem vias de acesso a outros mundos e a circulação entre eles é perigosa. Em geral, as pessoas sabidas - que entendem mais sobre os mundos dos encantes - alertam para o risco dos contatos com tais mundos e da necessidade de separação entre $o$ nosso mundo e $o$ deles $^{43}$. E a divulgação desses segredos colocaria esta separação sob risco, não se pode saber todos os mistérios sobre os mundos dos encantes, porque o mistério é inerente a ele. Todavia, as agências

\footnotetext{
${ }^{43}$ Se uso tais termos no singular é porque me remeto foi assim que os ouvi dos meus interlocutores, mas ressalto que no decorrer do texto uso "mundos" no plural, para deixar claro que me foram apresentadas várias versões não só sobre os "outros mundos", como também sobre os nossos.
} 
encantadas não ficam à espera da curiosidade humana de desvendá-las, elas mudam os rumos dos fenômenos e põem a perder os conhecimentos dos humanos sobre os mesmos. Para acessá-los, portanto, é preciso um contato permanente com os encantes. Se estas relações entre humanos e não humanos são postas em risco, estes saberes também saem de circulação. Não estou dizendo aqui que eles simplesmente deixam de existir ou se perdem, mas, se eles são adquiridos mediante os sinais deixados pelos encantes, caso eles deixem de dar tais sinais ou os humanos não tenham experiência ou sabedoria para percebê-los, eles param de circular, até que esta relação seja restabelecida.

Esta noção de saberes constituídos em relação é colocada por Gallois (2012), quando a autora aborda o processo de registro feito pelo IPHAN (Instituto do Patrimônio Histórico e Artístico Nacional) da arte gráfica dos Waiãpi como patrimônio imaterial. Ela elege como foco analítico os debates entre as lideranças waiãpi que participaram do processo de registro, buscando compreender como se transformam os regimes de autoridade diante da intensificação do debate entre "novas" e "velhas" gerações sobre propriedade e circulação de saberes. A autora atenta para o fato de que a circulação desses bens pode implicar na dispersão de princípios vitais, trazendo à tona uma série de perigos, portanto ela deve seguir regras rigorosas, pois os donos dos grafismos usados pelos Wajãpi não são propriamente os humanos que os produzem e deles fazem uso. Tudo o que existe no mundo tem dono, assim, os grafismos não foram "criados" pelos Waiãpi, mas repassados dos jarã para os Waijãpi. Assim, caso eles deixem esses saberes circularem livremente, eles serão cobrados posteriormente pelos jarã, portanto, essa circulação pode trazê-los sérios riscos. Deste modo os saberes são construídos em relação, portanto estão inseridos numa diversidade que as políticas de patrimônio não conseguem alcançar, já que se baseiam numa visão monopolista dos saberes.

As atuações de grandes empreendimentos que se instalaram na área desde os anos 70 e o processo de urbanização - intensificado nos primeiros 10 anos da chamada "Era Lula", na qual se ampliaram as bolsas 
de assistência e os empregos formais na região, fomentando o consumo e transformando radicalmente as paisagens - têm gerado impactos nas relações estabelecidas com os lugares encantados, muitos dos quais estão sucumbindo frente ao avanço do agronegócio e o crescente desmatamento e a poluição das águas e solos. Como estas transformações estão interferindo nas relações entre os Tremembé e os encantes? Os empreendimentos operam por uma lógica totalmente inversa à dos Tremembé, pois falam sobre "um meio ambiente" que está à espera das vontades humanas de transformá-lo conforme suas necessidades.

As reflexões sobre como os grupos indígenas vêm objetivando suas ideias sobre meio ambiente vem ganhando cada vez mais espaço no debate antropológico contemporâneo, na medida em que os problemas ambientais se agravam nas Terras Indígenas, obrigando-os a recorrer a outras formas de sobrevivência.

Os Tremembé, por exemplo, têm abandonado do seu cardápio alguns dos itens bastante consumidos por eles tradicionalmente, como revelam fontes documentais ainda do período colonial. A tartaruga pode ser o exemplo mais emblemático dessa lista - alargada demasiadamente nos últimos anos, passando a abranger vários outros animais, especialmente as caças, que são muito escassas atualmente, acompanhando a escassez das áreas de mata. A carne da tartaruga era um dos alimentos mais consumidos pelos Tremembé, que também aproveitavam seus cascos para fabricar utensílios domésticos, mas, desde o ano de 1986, a Portaria N-005 proíbe a captura de quaisquer espécies de tartarugas marinhas. Outros animais que poderiam ser capturados durante o ano todo, como lagosta e caranguejo, também têm, atualmente, sua pesca limitada pela legislação ambiental.

Não pretendo aqui, de modo algum, criticar a legislação ambiental, tanto por não ser esse o objetivo desta discussão, como porque compreendo que ela visa garantir a continuidade dessas formas de vida sobre as quais se referem. Todavia, a forma pela qual ela é imposta a populações tradicionais que veem os recursos que tradicionalmente vinham 
garantindo sua sobrevivência serem ameaçados pela ação predatória de empreendimentos que nada tem a ver com seus modos de vida, tem gerado muitos impasses no desenrolar de projetos de manejo de recursos. As políticas públicas não levam em conta o vasto e profundo conhecimento das comunidades tradicionais sobre seus ecossistemas, ainda que estes sejam os grupos mais impactados pela escassez de recursos. As discussões entre a comunidade e os empreendedores, postas durante os processos de licenciamento ambiental dos empreendimentos que se pretendem levantar no entorno da Área, nos revelam a forma como essas diferentes ontologias se põem em contato.

Um dos eventos que acompanhei em campo me mostrou claramente a forma como essas diferentes ontologias se punham em contato - a audiência pública realizada no ano de 2013, sobre a instalação de um dos parques eólicos na região. Durante a audiência, o atual diretor da Escola Indígena Maria Venância, na Praia de Almofala, Getúlio, que estava na plateia tomou a palavra e fez um longo discurso explicando os porquês da sua não aceitação à construção dos parques. Ele fez um breve histórico das transformações ocorridas na última década, após a construção da estrada que faz a ligação entre as praias do litoral oeste, no qual observou que a estrada poderia de fato trazê-los benefícios quando, por exemplo, o acesso a hospitais fica mais fácil e rápido, entretanto, destacou que, após a construção da estrada, as praias do lugar começaram a receber muito mais visitantes, o que atraiu grandes investidores como lagosteiros e criadores de camarão, que poluíam as águas e destruíam os ecossistemas marinhos. Destarte, os prejuízos acabavam superando os benefícios. Em determinado momento do seu discurso, ele lembrou dos inúmeras raposas e outros animais nativos que ele encontra diariamente mortos por atropelamento nas estradas. Seus questionamentos foram rebatidos pela assessora de imprensa da empresa que estava compondo a mesa da audiência. Num discurso caloroso, ela assegurou que a empresa "faria o possível" para poupar as raposas e os outros animais da região, entretanto, a "prioridade da empresa são os humanos", ou seja, se raposas precisarem 
ser sacrificadas em favor dos benefícios "aos humanos" que assim seria. Como a audiência já estava muito atrasada, o debate entre os dois não pôde ter tréplica. No final do evento, fui falar com Getúlio sobre sua intervenção, ao que ele me observou "você viu o que ela respondeu? Ela não entendeu nada...". E destacou que não se trata de colocar humanos e raposas em lados opostos, posto que, se não houver raposas também não haverá mais índios ou encantados, pois todas essas entidades que habitam aquelas áreas estão ligadas por redes de cooperação e interação das quais os Tremembé dependiam para sobreviver. Ou seja, tais relações são vistas como horizontais, se há hierarquias, elas não corroboram com a ideia de uma "humanidade" acima de todas as outras entidades.

Obviamente, as discussões sobre a produção e circulação de saberes entre humanos e encantados não se esgota aqui, mesmo porque, como espero ter esclarecido, estes saberes estão num processo incessante de transformação. Nos próximos capítulos da tese, darei destaque aos impactos que o crescimento do agronegócio na região tem gerado nas relações entre estas diversas ontologias que se põem em contato nesse processo.

\subsection{Os vivos, os mortos e os invisíveis}

Um elemento imprescindível para compreender as relações dos Tremembé com mundos encantados são as noções de invisibilidade, já que todas as entidades que podem transitar entre os mundos dos vivos e dos mortos têm a capacidade de ser tornar invisíveis ou visíveis a depender das circunstâncias. Para alcançarmos essas noções postas nas relações entre os Tremembé e os encantes é preciso levantar algumas questões, tais como: o que muda no status do sujeito quando ele adquire a capacidade de se tornar invisível? E em que circunstâncias isso ocorre? Como ocorre a passagem para o estado de invisibilidade? $O$ que esta invisibilidade pressupõe? 
A capacidade de se tornar visível ou invisível é uma das formas de se caracterizar encantes, mas, em tempos remotos, havia também seres humanos que portavam esse dom. Contam que alguns conheciam segredos capazes de torná-los invisíveis. Como falei no primeiro capítulo, é recorrente nos depoimentos dos meus interlocutores a referência a pessoas que desapareciam para se protegerem dos invasores europeus, e conseguiam, depois de passado o perigo, tornarem-se visíveis outra vez.

Atualmente, a capacidade de invisibilidade é restrita aos encantes. Os moradores das matas provocam sensações e sons, mas não se deixam ver, salvo as sereias que, frequentemente, são surpreendidas nas beiras das lagoas, quando são vistas por humanos e precisam fugir deles imergindo sob as águas. Nunca ouvi um depoimento no qual as Mães d'Água desaparecem, assim, para se disfarçar frente à presença de humanos, elas frequentemente aparecem sob a forma de animais. Outros moradores das matas, como o Caipora e o Guajara permanecem, em praticamente todos os depoimentos que coletei, invisíveis. Sobre o primeiro, alguns ainda arriscam uma possível descrição sobre sua aparência; já sobre o Pai do Mangue, todos me afirmaram nunca o ter visto nem ouvido quaisquer descrições sobre ele. Ainda assim, é possível identificar a presença deles através das sensações provocadas pela presença de encantes.

Muitos encantados já foram humanos, alguns deles morreram, outros se encantaram ainda em vida. Atualmente, os humanos, para se encantarem, precisam passar pela experiência da morte, mas, "nos tempos antigos", era fato corriqueiro o encontro de humanos com entidades encantadas que os transformavam também em encantados ainda em vida, sem que eles precisassem morrer para tanto. Havia duas situações em que os humanos se encantavam, ou porque entidades encantadas haviam "se engraçado" de alguém - como no caso de sereias que se apaixonavam por homens e os levavam consigo para o reino dos encantes - ou no caso de pessoas que, por terem bons feitos nesse mundo, acabam sendo poupadas da morte, podendo carregar seus corpos pelos vários mundos que percorrem. Nas atuais gerações, entretanto, não há pessoas que tenham 
tantos bons feitos neste mundo para merecerem tamanha dádiva, por isso, precisam morrer para serem encantadas. Após a morte, seus corpos são restaurados. Um dado apontado por praticamente todas as pessoas é o fato de que os encantados - tenham morrido ou não - têm corpos formados por uma materialidade invisível.

A ideia de que os corpos podem tornar-se invisíveis é mais um dado a ser analisado sobre a noção de "natureza" exposta pelos Tremembé, pois, mais uma vez fica claro o quanto esta noção é diferente daquela postulada pelas ontologias ocidentais. Além disso, revela também a ideia de humanidade para os Tremembé, pois, em geral, diz-se que, aqueles que se tornam invisíveis não deixam de ser gente, entretanto - ainda que afirmem que os encantados sejam gente - afirmam também uma diferenciação entre eles e os humanos, ou seja, são gente, mas não o mesmo tipo de "gente" que nós, humanos. E essa diferença passa pela questão da corporalidade seus corpos portam a capacidade de invisibilidade, mutabilidade e podem transitar por vários mundos sem perder a materialidade.

A ideia de que os corpos são mutáveis permeia toda a América indígena. De acordo com Viveiros de Castro (2015), em oposição ao antropocentrismo moderno, no qual há uma dessubjetivação total do não humano, o antropomorfismo ameríndio abre possibilidade para a subjetivação integral dos seres. Ao forjar o conceito de perspectivismo ameríndio, o autor argumenta que enquanto as cosmologias modernas se fundamentam no multiculturalismo, ou seja, na ideia de que há uma unicidade da natureza e uma multiplicidade de culturas, o pensamento ameríndio pressupõe exatamente o oposto: há uma unicidade da cultura e uma diversidade de corpos (EVC, 2011).

Já no final dos anos 80 , com a publicação de La nature domestique, Descola (1989) já apontava para a inconsistência da separação entre natureza e cultura, posta pelo pensamento ocidental, para pensar sobre as cosmologias ameríndias. Nessa obra, o autor elenca duas formas de concepção do mundo às quais ele se opõe. A primeira toma a natureza como sendo um double anime da sociedade, e a segunda a considera um conjunto 
de fenômenos que se realizam fora da ação humana. Ambos os enfoques, salienta o antropólogo, reservam um papel secundário às práticas que ora se focam somente nas produções do espírito, como se a prática fosse somente um meio para descrever discursos codificados, ora a prática se reduz à função adaptativa, perdendo a autonomia significante. O que Descola propõe é exatamente o contrário: analisar as relações do homem com o meio ambiente sob o ângulo das interações dinâmicas entre as técnicas de socialização da natureza e dos sistemas simbólicos que as organiza. Ou seja, ele propõe uma não hierarquização entre os níveis das práticas e da causalidade. Após uma rica e detalhada descrição sobre o plantio das roças e outras práticas dos Achuar em relação ao meio, ele conclui que, para eles, a floresta não é um universo incontrolado de espontaneidade vegetal, mas sim uma plantação sobre-humana onde a lógica obedece a regras outras que aquelas que regem a vida das hortas ( $p$. 398). De tal modo, a relação estabelecida entre a "bagunça" silvestre e a ordem das hortas mostra que a relação entre natureza e cultura não constitui uma ruptura, mas um continuum.

Numa publicação mais recente, já nos anos 2000, Descola atualiza este debate incorporando as reflexões propostas nas publicações de Viveiros de Castro sobre o perspectivismo ameríndio, no qual o antropólogo brasileiro, embora reconheça a importância dos trabalhos do colega francês para a desnaturalização da visão naturalista ocidental, se opõe a muitas das suas ideias. Em Par-delà nature et culture, Descola coloca a questão da corporalidade no centro do debate, pois, para ele, as reflexões sobre o corpo são a chave para a compreensão da relação entre natureza e cultura. Ele identifica, então, quatro ontologias, resultantes dos modos de relação entre fisicalidade e interioridade: o totemismo, no qual há uma continuidade de fisicalidades e interioridade entre humanos e não humanos; o analogismo, no qual esta relação é de descontinuidade, embora seja estruturada por relações de correspondência; o animismo que postula uma semelhança de fisicalidade e uma diferença de interioridades e, por fim, o naturalismo, que 
compreende as fisicalidades como semelhantes, sendo as interioridades o que distinguem essas relações.

Para Viveiros de Castro, a ideia de que o pensamento ameríndio objetiva as relações entre natureza e cultura como um continuum não se sustenta, pois ele observa que, embora haja uma constante no pensamento ameríndio que aponta para a existência de um plano onde a comunicação entre humanos e não humanos é plena, na prática essa comunicação nunca se efetiva de fato. Ainda que o mito sinalize que a comunicação entre humanos e não humanos é totalmente possível, essa plenitude só se torna efetivamente possível num tempo mítico, que remete à origem de tudo. $O$ exemplo do xamã - que, ao visitar outros mundos, sempre volta de mãos vazias, pois não pode trazer nada de lá - reafirma a diferença entre humanos e não humanos. Essas duas instâncias, embora estejam constantemente em relação, não são a mesma coisa, a diferença entre elas não seria dada pela diferença dos corpos, mas seria uma questão de perspectiva. Deste modo, não haveria um continuum entre natureza e cultura, ao contrário, todas as sociedades separam de alguma forma essas duas instâncias, o que muda são as formas como as mais diversas sociedades forjam esses dois conceitos.

Nesse ponto, tendo a concordar com Viveiros de Castro, pois, muitos dados etnográficos já expostos aqui revelam, no caso dos Tremembé, uma evidente ruptura entre humanos e não humanos. O encontro efetivo com encantados deve ser evitado ao máximo, salvo em raras situações - geralmente nas matas, águas ou nos rituais de cura - nas quais os humanos devem estar preparados, atentos e fortes de espírito. Todavia, não percebo, entre os Tremembé, a diferença entre humanos e encantados como uma questão de perspectiva. Nunca ouvi, por exemplo, a argumentação de que os animais se veem como humanos ou nos veem como animais. Os animais são protegidos pelos encantados que guardam os lugares e tudo o que neles vivem: tanto animais como plantas e águas. Uma Mãe d'Água que mora na lagoa da Batedeira, por exemplo, protege os peixes e outros animais que lá vivem e só ela pode permitir que eles sejam 
capturados. O mesmo acontece com o Caipora ou o Guajara em suas respectivas moradas. Pode ocorrer, entretanto, de as entidades para assustar ou observar mais de perto os humanos - transformarem-se em algum animal. Como alguns dos depoimentos aqui expostos já ilustraram. Quando isso ocorre, os humanos podem se confundir, mas aqueles que são mais experientes percebem alguns sinais de encantamento. Muitos pescadores ou caçadores, não raro, me afirmavam terem soltado presas por perceberem um olhar diferente ou, ainda, terem capturado presas que desapareciam misteriosamente. São sinais de que os encantados estão por perto, na espreita, observando suas condutas dos humanos com os lugares em que vivem. A capacidade de transformar seus corpos é apontada em quase todos os depoimentos sobre encantados: eles podem se apresentar sob a forma que quiser. Um importante modo de caracterização dos encantados é a mutabilidade de seus corpos.

A afirmação de que os corpos se transformam - humanos podem virar animais e vice-versa, seres ou objetos podem simplesmente desaparecer - coloca a noção de pessoa para os Tremembé não como algo imutável ou restrito à condição humana, os humanos podem se encantar e tomar outras formas, partir para outros mundos e, ainda assim, continuar sendo gente, como os depoimentos revelam. Todavia, para além da invisibilidade, o que diferencia as pessoas visíveis e as invisíveis? Quando falam sobre a humanidade dos encantados, os Tremembé aludem para a agência desses seres. Eles fazem no mundo as mesmas coisas que nós fazemos: trabalham, levantam roças, constroem casas e constituem famílias. As mães d'água são sempre vistas na beira das lagoas trabalhando nas suas tarefas domésticas, os ancestrais frequentemente são vistos em suas aldeias, com casinhas de palha e animais de criação... o que muda é a constituição dos seus corpos. São corpos invisíveis, mutáveis e não sofrem com a ação do tempo. A diferença entre o estado de humanidade e de encantamento é circunstancial. Alguns humanos podem se encantar, após a morte e essa passagem se dá através da transformação de seus estados corporais e não 
Após o encantamento, o que muda é que eles podem transitar por vários mundos e acessar segredos que nós humanos - devido ao nosso estado de materialidade que dificulta nossa percepção dos mundos encantados - não conseguimos. Os encantados veem coisas que apenas alguns poucos entre os humanos, os médiuns que nasceram com a coroa na cabeça, conseguem ver, assim os seus sentidos, as suas percepções dos mundos pelos quais transita são outras. Esta condição os faz muito mais sabidos do que nós.

Vários grupos na América Latina pressupõem a ideia de que lugares como matas, águas e céus são habitados por entidades invisíveis denominadas de encantados. Todas as etnografias sobre as populações indígenas no Nordeste do Brasil mencionam a presença de encantados. Porém, em outras regiões, também observamos o uso do termo "encantados" para se referirem a entidades invisíveis que circulam entre os humanos.

Na sua etnografia sobre as redes de relações xamânicas no baixo Oiapoque, Andrade (2007) também observa que, na região, a noção de pessoa também compreende seres visíveis e invisíveis e cabe aos pajés intermediar as relações entre essas duas categorias. Entre os invisíveis estão os Karuãna,os Bichos e os Encantados, e uma das características apontadas para este último é o fato de que eles não passaram pela experiência da morte, o que também é observado por Nascimento (1994) entre os Kiriri, que compreendem tais seres como pessoas que nunca morreram. Entre os Tremembé também há tal concepção, entretanto, ela não é uma "regra", pois muitos se referem à morte como um processo de encantamento: os ancestrais quando morrem, se encantam e passam a ajudá-los na luta pela terra. Entretanto, aqueles que se encantam após a morte têm seus corpos restituídos e é isso que os diferencia dos demais mortos, cujos corpos perecem e restam somente o espírito.

Nas entrevistas realizadas em campo, sempre que eu questionava se os encantados eram "gente", a resposta era quase sempre: "são gente, como eu e como você, mas são encantados". Ou seja, atravessar o limiar 
do encantamento não muda a condição ontológica da pessoa, o que muda é a natureza desse corpo, não sua condição de ser. Os seres humanos que se encantam, continuam, segundo os Tremembé, com a mesma estrutura social que tinham antes do encantamento.

Alguns afirmam - Seu Chico Brega, pajé já mencionado aqui, da aldeia da Batedeira - que os encantados são entes que têm corpos - embora estes não possam ser vistos por qualquer um - por isso, quando eles baixam em pajés, eles não enfraquecem seus corpos, ao contrário, há uma fusão de corpos e espíritos que se retroalimentam. Já os espíritos de mortos, quando baixam necessitam daquele corpo para se materializar neste mundo, por isso enfraquecem os corpos, quando se vão, deixam aqueles que os incorporaram cansados, fracos, pálidos... As pajés são, portanto, seres múltiplos, no sentido que abrigam uma proliferação de agências xamânicas Viveiros de Castro (2006) alerta que, se, com afirma Rodgers (2002) o termo "espírito" designa uma população de afetos moleculares, o mesmo se aplica ao xamã, eles são várias agências que habitam um só corpo, ou seja, neste caso a dualidade entre corpo e espírito se desfaz.

Para muitas pessoas, atualmente, a possibilidade de alguém se encantar está cada vez mais rara, por vários motivos. Hoje, na medida em que as moradas dos encantados vão rareando diante da degradação ambiental que varre a Área, os encantados também vão se afastando, à procura de onde haja "mata virgem". Se as matas ficam mais raras, logo, eles acompanham este movimento. Além disso, conforme esclarece Dona Francisca, as pessoas não têm mais merecimento para se encantar, pois esta é uma dádiva divina que não pode ser dada a qualquer um, somente aos que merecem "virar santo".

Porque eu acho que n'outro tempo, o povo se encantavam, gente virava santo... Agora nessa geração é que nunca ninguém teve licença de ser nada, só mesmo morre e fica aquela coisa no mundo, agora de outro tempo é que tinha as pessoas que tudo isso fazia, se encantava, virava santo... Noutro tempo... Moça véa ficava moça véa, no caritó, nunca casava nem se desonrava. Tudo, nesse tempo que passou, tudo isso existia, agora só nessa geração é que (risos) não existe essa coisa mais, mas existia tudo isso. Moça véa ficava 
moça véa e nunca no mundo via homem, agora não tem mais. Disse que gente virava santo, que tudo era coisa diferente, tudo besta, não sabia de nada... Aí hoje em dia até uma criança sabe de tudo, de primeiro tinha gente véi, já véi, tudo inocente, sem saber de nada. Era assim. E esse trabalho apresentou nesse povo e diz que é os encante, e a pessoa que recebe o trabalho fica achando que é mesmo.

Muitas das pajés se referem a vários santos católicos como encantados. No altar de praticamente todas elas, inclusive, havia a imagem do Padre Cícero, santo do catolicismo popular, muito venerado na região e também considerado como sendo encantado pelas pajés. Muitos corroboram com Dona Francisca a visão de que as pessoas não se encantam mais porque ninguém tem merecimento para se santificar.

Em uma das etapas de campo, no mês de julho de 2014, fui acompanhar uma equipe de arqueólogos do Instituto de Patrimônio Histórico e Artístico Nacional (IPHAN) que intentava realizar os registros de prováveis sítios arqueológicos na Área. Eu levei o grupo à casa de Seu Estêvão, um senhor de 80 anos que guarda consigo alguns objetos por ele encontrados nas dunas de Almofala. Ele diz que, no lugar onde encontrou os objetos moram muitos índios que viveram em outro tempo que, até hoje habitam seus "lugares de origem", em casas de palha, conforme viviam "os índios velhos". Ao ser perguntado sobre quem são esses encantes encontrados por Seu Estêvão nas dunas, ele responde:

Seu Estêvão: sabe o que é? É porque lá era as aldeia deles.

Juliana: aí eles ainda vivem lá?

Seu Estêvão: não sai de lá!

Juliana: mas esses encantados são gente que morreu ou que não morreu e se encantou?

Seu Estêvão: não, lá só vive morto! Isso é tão perigoso, criatura! (...) Eu soube de coisa da Raimundinha que eu não sabia! (...) Ela tava lá, fazendo renda.

(...)

Juliana: e por que uns veem e outros não?

Seu Estêvão: porque tem que ter merecimento!

Raramente ocorre, como no caso de Seu Estêvão, de alguém que não trabalha com incorporação, mas ainda assim consegue ver os encantados. O contato com tais entidades deve ser evitado, pois elas podem 
lançar feitiços e levar as pessoas para o "lado dos encantados". Assim, somente os pajés podem invocá-los e, se os invocam, é porque precisam deles nas situações de cura. No cotidiano, entretanto - conforme nos apontam vários dos depoimentos aqui citados -, eles se esforçam em afastar as pessoas dos sítios por eles escolhidos para morar, a menos que eles queiram levar alguém consigo, como no caso das Mães d'Água, que muitas vezes, se apaixonam por pescadores que frequentam as lagoas onde elas moram e tentam levá-los, como no caso contado por Seu João Gomes, agricultor, pescador e morador da Tapera:

\begin{abstract}
Quando eles vinham do lado de cima, ela tava do lado de baixo, batendo roupa. Aí ela vivia lá, até que ela teve um namoro com um caboclo que morava por lá pertinho da lagoa. Queria namorar com o homem! Ela encantada, sabe? Aí o pai dele se assombrou e foram morar n'outro canto. Como é que uma encantada quer namorar com um homem, né? Ele não podia olhar pra lagoa que tava vendo ela, toda vez que olhava, ela tava lá! Quando era de noite, que ele ia se deitar, ela batia lá na rede dele. Mas aí era uma mulher bonita! E ele doido! Ficou doido! Assombrou-se! Aí ela disse "olha, lá no pé daquela cerca... - que tinha uma cerca que entrava na lagoa - aí você vai no pé da cerca que lá tem uma mala pra você, eu tou the dando, pode ir pegar, a mala é sua". Só que ela queria que, quando ele entrasse, ela pegava ele aí encantava e pronto! Ela ia ficar morando mais ele. Teve também um tio meu, que ele vinha na beira da lagoa, aí, quando ele olhou, tava uma curimatã de barriga pra riba, só batendo as guelras assim, aí ele disse "olha essa peixa, vou levar, ó!" Aí ele deixou uma perna na ribanceira e botou a outra dentro d'água, quando ele foi botando a perna dentro d'água pra pegar a peixa aqui, um negócio pegou-lo na perna, pra puxar pra dentro. Aí ele foi e pulou pro seco e olhou, cadê a peixa? Era ela que queria pegá-lo pra levar pra encantá-lo também. Aí foi indo e ele via muito ela nessa lagoa...
\end{abstract}

Muitos dos depoimentos, sobretudo quando se referem às Mães d'Água, a descrevem nas lagoas de Almofala lidando com os afazeres domésticos como qualquer outra mulher no grupo, elas estão quase sempre lavando roupa, lavando louças... além disso, como quaisquer outras pessoas, eles erguem suas moradias, criam animais, têm famílias... nos casos dos personagens da realeza, as moradias são descritas como imensos castelos, já os índios velhos que se encantaram, continuam morando em casinhas de palha. Pouco se sabe, todavia, sobre suas relações de 
parentesco e suas histórias de vida, pois o contato com tais seres é bem esporádico e só é possível saber um pouco mais sobre suas vidas particulares quando eles estão incorporados em algum pajé e se dispõem a conversar sobre suas histórias. No caso dos pajés, eles também ficam sabendo de fragmentos da vida dos encantados através dos sonhos, como no caso narrado por Dona Maria Bela, em que ela pôde visitar sua mãe e saber onde ela estava vivendo depois da morte:

\begin{abstract}
Aí a mamãe já tinha morrido e eu sonhei com ela. Eu ia andando num lugar aí entrei numa casona. Aí quando eu cheguei nessa casona, que eu entrei, dei com ela lá na cozinha da casa, aí 'mamãe, eu vim Ihe buscar', aí ela disse 'é, minha filha, mas eu não posso mais voltar pra lá não, tenho vontade de volta, mas não posso', 'porque você não pode? Porque não tem dinheiro pra pagar a passagem, pois eu tenho um gorózinho aqui no bolso, dá pra nós comer e pagar a passagem', ela disse 'ê, minha filha, eu não vou mais não', 'a mãe ta com fome? Eu não vejo fogão aqui, não vejo nada', 'não minha filha, eu não sinto mais fome não'. Aí tinha uma porta, eu olhei, era o jardim mais lindo do mundo. Aí tinha um homem enchendo uma vasilha d'água. Aí, quando eu cheguei lá no fim da casa onde eu tinha entrado, eu vi uma mulher com os traje de Santa Terezinha ou os traje assim de Santa Rita, né? Aí a mamãe foi e disse assim 'toma a bênção a essa mulher que ela é sua madrinha'. A mulher era morena clara, eu tomei a benção a ela três vez. (...) minha madrinha é Nossa Senhora. Aí uma mulher de branco apareceu. Foi um sonho verdade mesmo. Aí a mulher de branco disse 'vá s'embora!', eu digo 'eu não vou não, só tenho raiva de empregado porque quer ser mais do que o dono, isso aqui é da minha madrinha, tu é uma simples empregada e vem mandar eu ir m'embora. Aqui ta a minha mãe e a minha madrinha, eu vou embora por quê?', aí a mulher disse 'não é o seu tempo, de você estar aqui.' (...) Minha madrinha é Nossa Senhora da Conceição.
\end{abstract}

Aos meus olhos, as narrativas eram de uma contradição que não cabia na minha concepção de mundo "ocidental", que procura sempre "colocar cada coisa em seu lugar". Como assim, morreram, mas estão vivos, "vivem mortos"?! Ora são expostos como seres que controlam a "natureza", ora são a própria "natureza" - as matas, as plantas, os animais -, todas essas coisas têm um encante, resta "descobri-lo". Morte e vida não são, assim, categorias excludentes.

A passagem dos mundos visíveis para os invisíveis é relatada como algo extremamente perigoso, pois o caminho de volta é, praticamente, 
inviável. São poucas as narrativas que falam de casos de desencantamento. Na maioria dos depoimentos, tal passagem é, mesmo, impossível. Há, entretanto, um caso emblemático que contam da época em "havia os padres santos", como se referem aos padres missionários que construíram a igreja ${ }^{44}$. Contam que, antes da primeira missa do dia, o padre ordenou a alguns homens que pescavam na Lagoa da Criminosa - uma lagoa que se forma nos períodos de chuva, entre dois morros que se situavam atrás da igreja - que lançassem sua rede três vezes na água e, no terceiro lançamento, eles haveriam de fisgar um animal. Depois da pesca, independente de qual fosse este animal, ele deveria ser levado à igreja e solto entre os fiéis que assistiam à missa. Assim foi feito, os homens foram pescar e qual não foi a surpresa que tiveram ao, no terceiro lançamento da rede, pescarem uma enorme cobra que, conforme as ordens do padre, foi prontamente levada ao interior da igreja e solta entre os fiéis. A cobra começou então a circular entre os presentes, até que parou diante de uma moça. Diante do terror causado pelo medo do animal, o padre ordenou que ela não saísse nem tivesse medo, pois algo muito importante seria revelado naquele momento. A cobra, então, aconchegou-se em seu colo e começou a mamar em seu seio, assim, na medida em que a moça ia amamentando o animal, ele foi-se transformando em um bebê. Findada a transformação, a moça assumiu perante todos que, meses antes, havia parido um bebê, mas com medo da repercussão da notícia de que ela havia engravidado, resolveu jogá-lo na lagoa. A cobra era, pois, a criança que se havia encantado. Desde então, a lagoa ficou conhecida como Lagoa da Criminosa, trata-se de uma lagoa intermitente, que só se forma nos períodos de chuva, quando as águas se acumulam entre as dunas.

A narrativa nos coloca diante da possibilidade do desencantamento, entretanto, todas as pessoas que me contaram esta narrativa, esclarecem que o desencantamento se concretizou não só porque a cobra fora lançada dentro da igreja, um território sagrado, mas também

\footnotetext{
${ }^{44}$ No segundo capítulo, falarei um pouco mais sobre a história do aldeamento a importância da igrejinha de Almofala como marco territorial para o grupo.
} 
porque estavam circunscritos em um outro recorte temporal: os "tempos antigos", onde $o$ ato de encantar e desencantar era corriqueiro para os índios. Muitos contam que alguns dos índios que, para se esconderem dos invasores europeus, tornaram-se invisíveis, posteriormente conseguiram tornar-se visíveis novamente, já outros encantaram-se por toda a eternidade e estão ainda hoje nos arredores do lugar, com suas casas e famílias e, assim, nunca foram capturados e não padeceram diante da guerra estabelecida com os colonizadores.

No depoimento abaixo, Seu Chico Brega explica que os encantados são as pessoas remanescentes do começo do mundo, quando tudo era encantado:

Juliana: quer dizer que esses encantados, eles não morreram? Não é gente que morre e volta?

Chico Brega: não, isso aí é encantado. É do começo do mundo.

Juliana: e como era nesse começo do mundo?

Chico Brega: no começo do mundo, era noutros tempos, né? Não tem os índios? Eles são índios também, os índio véi, antigo, eles não morreram, eles se mudaram sabe? Eles não morreram, eles se mudaram. Se mudaram porque foi no tempo de outros séculos que eles eram escravos, aí por causa dessa escravidão que houve, eles se mudaram pra outro mundo. Pra outro mundo não, pra este mundo mesmo, mas eles se encantaram tudim, que eles eram índio, eles sabiam de oração, sabiam dessas coisas... Não tem oração que a gente faz pra se esconder? Do mesmo jeito é eles, eles se escondem também. Por aqui. Quantos índios não tem por aqui encantados? Tem muitos! Não morreram, não. São vivos.

Declarações como estas revelam algo extremamente relevante para a pesquisa que ora apresento, já que pretendo compreender as formas de temporalidades que se desenrolam entre os Tremembé, diante das transformações que vêm atravessando nas últimas décadas. Seu Chico coloca os encantados como seres capazes de driblar a passagem do tempo, já que vivem em realidades nas quais o tempo, da forma como o concebemos não faz sentido. Como afirmam os Tremembé, "nos tempos antigos", aqueles que se encantavam passavam para um estado de existência onde a passagem de tempo não os atinge. Os encantados vivem num estado onde o "tempo não passa". Àqueles que se encantam é dada a 
plenitude de um tempo imutável. Ou seja, malgrado as intensas transformações às quais foram submetidos, a possibilidade do contato com mundos encantados coloca os Tremembé diante de lugares onde a exuberância e a fartura nunca acabam.

Não pretendo aqui, evidentemente, encerrar a discussão sobre esta natureza apresentada nas relações entre os Tremembé e os encantes, mas apenas lançar algumas reflexões que serão amadurecidas nos capítulos seguintes.

O que temos, por ora, é uma natureza que se apresenta como uma entidade plena de intencionalidade que se transforma a todo instante e que serve de morada a diversas entidades humanas e não humanas. Diferente da "natureza" posta pelas ontologias naturalistas, que está sucumbindo às ações humanas, a natureza, para os Tremembé, se transforma cotidianamente para limitar as ações humanas e, assim, perpetuar sua existência. Mas, se a natureza é plena de agência, como explicar as severas consequências da devastação ambiental que varre a área e causa tantos transtornos aos Tremembé e aos encantes? Em que medida a natureza - com seus encantes - reagem aos atuais problemas ambientais na Almofala dos Tremembé? No próximo capítulo, ao descrever as dinâmicas territoriais vivenciadas pelo grupo nos últimos anos, tentarei elucidar tais questões. 


\section{DINÂMICAS TERRITORIAIS DOS TREMEMBÉ DE ALMOFALA}

A partir de agora, tentarei elucidar elementos mais específicos das relações entre humanos e encantados em Almofala no que tange aos usos dos lugares e ao cotidiano do grupo. Dividirei este capítulo em duas partes, na primeira, darei mais ênfase às dinâmicas territoriais vivenciadas pelo grupo e aos impactos causados por fatores tais como a especulação imobiliária, o agronegócio e a intensificação da urbanização sobre as áreas chamadas de moradas dos encantados, que os Tremembé descrevem como sendo áreas onde há natureza - águas, matas e dunas. A segunda parte será dedicada às formas através das quais diferentes agentes - humanos ou não - habitam os lugares de Almofala onde há natureza.

Espero ter deixado claro no capítulo anterior o quanto os conhecimentos dos Tremembé sobre seu ambiente passam pelas relações estabelecidas com os encantados. As pessoas sabidas e experientes, que conhecem mais do que a maioria os segredos cuidadosamente revelados pelo sistema de encante, alertam para a forma como a degradação ambiental vem diminuindo drasticamente as áreas de mata e afastando delas os encantados que as escolhem como morada. Deste modo, faz-se preciso refletir sobre essas extensas redes de relações que abrangem encantados, Tremembé, a legislação ambiental, a exportação do coco, a balança comercial do país, entre vários outros elementos.

Evidentemente, as mudanças nas paisagens atingem também os encantados que por elas circulam, por isso, discorrerei neste capítulo sobre as recentes transformações territoriais vivenciadas pelos Tremembé de Almofala e pelos encantados que dividem com eles algumas áreas em Almofala. Para tanto, farei um breve histórico sobre a presença do grupo na região desde os primeiros relatos de missionários e viajantes ainda no período colonial até mais recentemente, dando ênfase às mudanças ocorridas especialmente após os anos 60, quando as disputas territoriais se agravaram na região do Vale do Acaraú. 


\section{Parte 1}

As considerações a seguir abordarão as dinâmicas de ocupação dos Tremembé pelo litoral do Ceará, salientando as atuais configurações territoriais frente ao avanço do agronegócio do coco na região.

\section{Histórico da ocupação dos Tremembé no litoral do Ceará}

Os relatos coloniais sobre os Tremembé são demasiadamente escassos. Tomei como referência dois estudos publicados nas décadas de 50 e 60, respectivamente por Pompeu Sobrinho (1951) e Studart Filho (1965). Ambos examinaram vários documentos que mencionam a presença do grupo na faixa litorânea que se estende da foz do rio Gurupi até a foz do Apodi, áreas atualmente situadas nos estados do Maranhão, Piauí e Ceará. Sobrinho afirma que há também indícios da presença de Tremembé em praias do litoral do sul e sudeste brasileiros. No entanto, Pompeu Sobrinho aponta para a dificuldade de encontrar dados históricos sobre o grupo nos documentos coloniais, chegando a descrevê-los como um dos mais "misteriosos e desconhecidos" grupos que habitavam as costas brasileiras. Ainda assim, sua pesquisa encontrou registros da presença do grupo no litoral do Ceará desde a chegada dos primeiros europeus que passaram pela região, como revelam os relatos do cronista Pedro Mártir de Algéria, ao descrever a expedição de Vicente Pinzón pela costa da América, entre os anos de 1500 e 1501 . Cerca de um ano e meio depois, outra expedição - a primeira comandada pela Coroa Portuguesa com o objetivo de explorar a costa brasileira, sob o comando de Américo Vespúcio - também faz referência à presença dos Tremembé nas proximidades da barra do Rio Curu. Depois disso, somente no início do séc. XVII, o relato "Viagem ao Norte do Brasil", do Padre Capuchino Ivo d'Evreux e - em meadas do mesmo século - a "Crônica da Missão dos Padres da Companhia de Jesus no Estado 
do Maranhão", do jesuíta João Filipe Bertendorf oferecem outras preciosas informações sobre o grupo.

Com base em documentos coloniais, ambos os autores descrevem alguns costumes desses índios, especialmente no que diz respeito à moradia e à alimentação. Conforme os registros, eles viviam basicamente da pesca, na qual utilizavam técnicas semelhantes às que usam hoje, ferramentas e embarcações fabricadas por eles próprios. A caça e a agricultura eram atividades secundárias, embora tivesse também sua importância, já que eles mantinham pequenas roças de mandioca e há evidências de que plantavam também o algodão, pois possuíam fusos. Mas a base alimentar constituía-se de frutos do mar, sobretudo grandes tartarugas marinhas e tubarões que eram usados não só na alimentação, mas também para a confecção de flechas usadas nas guerras e caçadas, feitas com os dentes do animal. A referência ao caju como um elemento essencial na alimentação do grupo também é ressaltada pelos autores.

Os cronistas também destacam seus "dotes físicos": eram pessoas de alta estatura. Pinzón chega a afirmar que eram mais altos que os germanos ou húngaros, além de serem fortes e ágeis. Esses "dotes físicos", aliados às habilidades marítimas, Ihes possibilitavam organizar uma forte resistência à ocupação europeia na região, elaborando estratégias de combate que resultaram em muitas baixas para os europeus. As relações entre os Tremembé e os lusos foram marcadas por forte animosidade, que impossibilitava o domínio português sobre as terras litorâneas ocupadas pelo grupo. Mesmo durante a invasão holandesa na região, o grupo manteve obstinada reação ao projeto colonizador, o que obrigou os invasores a construir um forte em Jericoacoara com o objetivo de se proteger das investidas dos índios e assegurar a conquista do território.

Entretanto, mesmo empreendendo firme resistência, as perdas por parte dos índios depois de tantas batalhas contra os invasores reduziram drasticamente a população e os territórios por eles ocupados. Pelos idos de 1656, um grupo formado pelo principal Tremembé, Tataguaçu, e vários outros índios se dirigiu ao Maranhão para negociar um acordo de 
paz com o Governador André Vidal de Negreiros. O acordo, todavia, não cessou as batalhas que continuavam deixando um lastro de morte em ambas as partes. Segundo Betendorf, no ano de 1674, o Governador do Maranhão, Inácio Coelho, organizou uma aparatosa expedição comandada pelo Capitão-mor Vital Maciel Parente, que contava inclusive com dois padres da Companhia de Jesus. A ofensiva sacrificou barbaramente homens, mulheres e crianças, nem mesmo os bebês foram poupados. A vingança dos invasores foi comemorada em São Luís, na igreja matriz da cidade, onde os sobreviventes foram agradecer a Deus e a Virgem Nossa Senhora da Vitória pelo resultado da empreitada.

Já no final do século XVII, após esses ataques sangrentos, o grupo, disperso pelo litoral, foi aldeado na região do Camucim e também nas praias de Lençóis (Sutdart Filho, 1965). Dessa área, passaram, no início do século XVIII, para as margens do rio Aracatimirim, Município de Acaraú, onde, no ano de 1702, foi formado o aldeamento que tinha à frente o Padre José Borges de Novais, pertencente à Irmandade de Nossa Senhora da Conceição. Nesse lugar, iniciou a construção de uma pequena igreja em estilo barroco, finalizada em 1712.

Poucas décadas depois, o Marquês de Pombal inaugurou uma nova política colonial na qual os aldeamentos indígenas foram extintos e alguns deles foram elevados à categoria de vila. ${ }^{45} \mathrm{O}$ aldeamento dos Tremembé, todavia, não estava entre estes. Assim, no ano de 1749, os Tremembé foram transferidos à Vila de Soure. Conforme Stuart Filho, o próprio Capitão-mor dos índios teria formulado o pedido desta transferência, contudo, a decisão não teria sido unanimidade no grupo, já que, no mesmo documento, o autor enfatiza que o diretor da vila teria mandado incendiar as casas dos índios para obrigá-los a segui-lo à nova Vila de Soure. Sobre o assunto, Peixoto da Silva (2003) infere que o capitão e seus seguidores longe de serem movidos pelo desapego àquelas terras, queriam, antes, garantir o acesso aos benefícios que a nova condição de vila poderia trazê-

\footnotetext{
45 Sobre o assunto, ver Peixoto da Silva (2003). A autora descreve a formação das Vilas Pombalinas no Ceará Grande.
} 
los, para tanto, baseia-se no fato de que, tão logo o capitão-mor concluiu que tais benefícios se aplicariam não só às vilas, mas a todos os índios que habitavam o Brasil, propôs a volta do grupo às suas antigas moradas à beira do Aracatimirim.

Não tendo o grupo, evidentemente, se adaptado às novas condições que Ihes foram impostas na Vila de Soure, alguns se dispersaram pelo litoral, outros foram para a Capitania do Maranhão. Mais tarde, no ano de 1766, os Tremembé reocuparam suas terras nas margens do rio Aracatimirim, onde surgiu a pequena aldeia tomado o nome de Almofala. $O$ documento de Stuart Filho assevera que, no ano de 1818, "existiam ainda na Paroquia de Nossa Senhora da Conceição de Almofala índios dessa parentela que, pacificamente, se dedicavam à agricultura e à pesca" ( $p$. 168).

Desde então, ainda que muitos se tenham dispersado por outras regiões no litoral que se estende do Ceará ao Maranhão, muitos Tremembé se fixaram em Almofala, nos arredores da pequena igreja de Nossa Senhora da Conceição. Essa igreja até hoje configura um marco importante e um argumento de peso na luta pela posse definitiva das terras que tradicionalmente ocupam desde a fundação do aldeamento. Mas não só a igrejinha - que faz parte do cotidiano dos moradores de Almofala, pois ocupa lugar de destaque no centro do distrito - configurou uma referência espacial para o grupo. Lugares mais distantes, como o Maranhão, também são referências importantes. Algumas pajés chegam a afirmar, como expus no capítulo anterior, que há uma linha que passa pelo Maranhão, trazendo de lá muitos encantados que portam consigo a força que emana do lugar. Lugares como a Ilha do Codó ou a Praia dos Lençóis são apontados por muitas pajés como sendo moradas de encantados.

Nos arredores da igrejinha se formou um pequeno povoado feito com casas de taipa e palha até que, no final dos anos 1890, a ação dos ventos moveu uma duna situada a leste da igreja por sobre o povoado que se viu, aos poucos, sendo engolido pelo areal, que começou a cobrir as casas e até mesmo a igreja. Em 1898, o vigário da Paróquia do Acaraú, em 
visita à comunidade, percebeu que o teto da igreja estava desabando, indo queixar-se da situação ao bispo da diocese do Ceará, Dom José, que o autorizou a retirar as imagens e levá-las à Capela de Nossa Senhora dos Navegantes, situada no Tanque do Meio, atual cidade de Itarema. Tal remoção, obviamente, não agradou aos moradores de Almofala que tinham profundo apreço à igreja e às imagens que ela continha. Souza (1983), baseando-se nos dados revelados pelos escritos de Braga (1964), descreve os conflitos ocorridos na ocasião da remoção. Segundo a autora, o pároco do Acaraú organizou uma missa que - embora tenha sido celebrada às 4 horas da madrugada, sob o argumento que, nesse horário, a ventania seria mais branda - reuniu cerca de 3 mil pessoas vindas não só de Almofala como das localidades vizinhas. $O$ intuito seria celebrar a missa e seguir em procissão até o Tanque do Meio, a $12 \mathrm{~km}$ de distância. No entanto, os sacerdotes não contavam com a forte resistência por parte da população. De acordo com a socióloga:

\begin{abstract}
Os andores já estavam sendo preparados para o transporte das imagens, quando chegou um aviso para o padre, de que atrás do morro encontrava-se um grupo de caboclos armados, para impedir a saída das imagens.

O sacerdote mandou um convite para os chefes do grupo irem ter um entendimento com ele. Apareceram dois indivíduos chamados José Caboré e Pedro Duro, ambos armados de cacetetes e punhais. Ouviram as explanações do padre e afirmaram que as imagens não iriam sair dali para nenhuma parte, nem mesmo se Deus fosse buscá-las. O reverendo resolveu pedir auxílio ao subdelegado Joaquim Martins dos Santos Filho, que, para evitar o conflito, prendeu os dois chefes. Enquanto conversavam com o subdelegado e o padre, uma mulher conhecida como Joana Camelo, entrou na igreja, apoderou-se da imagem de Nossa Senhora do Rosário e correu em direção ao morro onde estavam os homens acampados. $O$ padre gritou para que alguém detivesse a ladra. Ninguém moveuse. Ele próprio teve que enfrentar a luta. Joana Camelo, ao ser interpelada pelo padre que a segurou pelo braço, negou-se a entregar a imagem. Enquanto isso, armou-se uma confusão geral. Alguns homens, vendo o padre metido na luta, resolveram vir em seu auxílio, intensificando-se mais ainda o conflito.
\end{abstract}

(Souza, 1983, p. 42)

Por fim, as imagens só puderam ser levadas da igrejinha quando os líderes do grupo foram presos pela polícia local e, mesmo a contragosto 
dos demais moradores, as imagens foram levadas em procissão até o Tanque do Meio. Depois disso, as dunas cobriram todo o pequeno povoado e seus moradores se dispersaram, a maioria deles fixou morada na localidade da Lagoa Seca, situada a, aproximadamente, $18 \mathrm{~km}$ do local.

\section{Terras da Santa}

Foi somente nos anos 40 do século passado que, mais uma vez, os ventos moveram a enorme duna que se formara sobre o povoado, deixando a torre da igrejinha emergir sob o areal. Os moradores, cheios de afeto pelo lugar, resolveram antecipar a ação dos ventos e retirar a areia com as próprias mãos. Muitos moradores mais velhos contam - numa narrativa cheia de emoção - que, durante meses, a tarefa de caminhar até a igreja munidos de latas e cabaças e trabalhar na retirada da areia se incorporou às atividades do dia-a-dia, até que ela foi totalmente descoberta. Ainda nos anos 80 do século passado, a igreja foi tombada pelo então Serviço do Patrimônio Histórico e Artístico Nacional (SPAHN) e algumas das imagens que tinham sido retiradas décadas antes foram recuperadas.

Os habitantes de Almofala contam que a construção da igreja foi um acordo entre a comunidade e a rainha de Portugal que, por milagre de Nossa Senhora da Conceição, trocou aquelas terras por uma estatueta de ouro. Nas palavras de Dona Maria Bela, nascida em 1940:

\footnotetext{
A princesa tinha dado a libertação pros negro, pros caboclo no dia treze de maio de 1888, que chamavam três oito, chamavam a era dos três oito. Foi quando foi libertado o Brasil, no dia treze de maio de 1888, assim falou a minha vó. E ela disse que essa igreja foi fundada devido um índio. O índio achou a santa na praia, a santa era de ouro. Aí trouxeram a santa, a santa de ouro, eles fizeram uma tocazinha de palha, um tijupá de palha - o índio chama essas coisa é tijupá - e colocou a santinha dentro. Mas não sabia se era de ouro, de que era, né? Aí veio um rapaz que ia apanhar o navio, de Fortaleza - disse que a estrada era esse beco aqui, a estrada antiga - aí o rapaz passou, disse que a toca do índio era ali em cima desse alto, a casa do índio, aí ele olhou, viu aquela santa, ele verificou e conheceu que era uma Nossa Senhora da Conceição,
} 
mas de ouro. Então, o rapaz apanhou o navio e foi pra Portugal. Chegou lá, disse pra monarquia, aí a princesa mandou um navio com o dito rapaz, que voltou pra trás pra dizer ao índio que mandasse Tupã pra ela, que ela mandava fazer aqui uma casa e encher de Tupã. (...) Aí quando chegou o navio com os pedreiro, o material da igreja, tudo vinha dentro dos navio, parece que vinha uns dois navio, veio um padre, um grumessor ${ }^{46}$, o grumessor tirou duas légua de terra em quadra para o índio. E aí os pedreiro foram cuidar da igreja.

As mais diferentes versões concordam que a área atualmente ocupada por eles foi conquistada depois que um índio velho achou a imagem de uma santa de ouro, Nossa Senhora da Conceição, e para ela construiu uma pequena barraca de palha, onde os demais se reuniam para louvá-la. Com o tempo, a notícia do achado da santa chegou aos ouvidos da então rainha que propôs, em troca da imagem, a construção de uma igreja e a doação de quatro léguas de terra em quadra para que nela os índios pudessem viver harmoniosamente. Assim sendo, a área não foi doada a um indivíduo, mas ao coletivo, predominando a ideia do uso comum das terras. Até hoje, muitos ainda se referem à área como sendo a Terra da Santa.

A igreja, portanto, simboliza o acordo entre os índios e a rainha. Isso explica tanto empenho e dedicação durante o trabalho de retirada das areias. Mesmo aqueles que moravam a léguas de distância, caminhavam diariamente até a igreja para a árdua tarefa. Atualmente, mesmo os que não vivenciaram a experiência contam com uma imensa riqueza de detalhes o trabalho de retirada das areias da igreja. Dijé, neta da Chica da Lagoa Seca, conta que a avó juntava todos os filhos e a imensa prole trabalhava diariamente no intuito de que a igreja se mostrasse novamente.

Dona Zeza, nascida em 1935, conta até hoje que ela mesma trabalhou na retirada do areal. Ia com o pai que a levava no tuntum - ou seja, nos ombros - até o alto do morro, de onde ela apanhava uma pequena quantidade de areia em uma cabaça e descia escorregando pela duna para jogar areia fora, no sentido do vento. Destarte, os habitantes foram

${ }^{46}$ Agrimessor, encarregado de medir as terras. 
ajudando o morro a caminhar e, nos termos de Dona Zeza, hoje ele vive, no cercado do Zé Maria Monteiro, e se chama Morro do Comum. Antes, chamava-se Morro da Criminosa, por conta da história - já exposta no segundo capítulo - da mãe que jogou a criança na lagoa formada no pé do morro e que se encantou numa cobra que, mais tarde, se desencantou quando entrou na igreja enquanto os padres celebravam uma missa.

A experiência de redescobrimento da igreja trazia à tona a história da santa achada pelo velho índio e que proporcionou a posse definitiva daquelas terras, afinal, quem poderia questionar o donativo de Nossa Senhora? Este questionamento me foi levantado inúmeras vezes por muitos dos habitantes mais velhos.

A perspectiva de uso comum das terras tem-se tornado impraticável nas últimas décadas, diante das transformações trazidas sobretudo pelo acirramento das disputas territoriais. Nos depoimentos sobre a ocupação da Área Indígena, fala-se muito de uma época onde era "tudo no aberto", ou seja, não havia a marcação das cercas que atualmente cortam toda a área, materializando as disputas agrárias. A necessidade de cercar as áreas por eles ocupadas fez-se presente entre os índios como forma de garantir a posse da terra, diante da incerteza da demarcação, pois o processo está estagnado há mais de vinte anos. A Área Indígena Tremembé de Almofala foi delimitada pela FUNAI, no ano de 1991, entretanto, desde então os advogados da empresa Ducoco conseguem contestar os laudos antropológicos em juízo, numa batalha burocrática que vem se desenrolando sem, até o momento, vislumbrar uma solução. Mais adiante voltaremos ao assunto do agronegócio do coco na região, por ora, é preciso destacar que a luta contra a Ducoco foi apenas mais um episódio de um processo de esbulho que começou nas guerras coloniais e seguem até o presente, conforme veremos na sequência.

No final da década de trinta, foi aberto o primeiro cartório da cidade do Acaraú ${ }^{47}$, então se deu início ao processo de regulamentação

\footnotetext{
${ }^{47} \mathrm{Na}$ época, a atual cidade de Itarema ainda não havia se emancipado, compondo a cidade de Acaraú.
} 
fundiária das áreas tradicionalmente ocupadas pelos índios. Muitas das terras hoje ocupadas pelos Tremembé foram registradas nessa época à revelia dos seus habitantes, que nem mesmo tinham conhecimento da necessidade de tantos procedimentos burocráticos para assegurar a posse daquelas terras.

Desde então, os conflitos agrários foram aumentando progressivamente. A Terra da Santa foi, progressivamente, ganhando valor de mercado. Ainda que, conforme os depoimentos colhidos em campo, até bem poucas décadas, ainda houvesse muita terra "no aberto" onde qualquer um podia levantar uma casinha de palha e uma roça para viver com a família, havia também muitas áreas invadidas por posseiros que expulsavam os moradores de suas terras. Destarte, esse processo de esbulho foi-se perpetuando a tal ponto que, atualmente, as áreas "no aberto", ou seja, que não são cercadas, não existem mais, ao contrário, todas as terras são cercadas e disputadas palmo a palmo.

Na década de 60, uma disputa por uma faixa de terra localizada na Passagem Rasa resultou no sequestro, seguidos de tortura e assassinato de três índios que tiveram suas terras invadidas por um posseiro. $O$ triste episódio escancarou a necessidade de organização coletiva para assegurar a posse das terras. Sobre o assunto, Seu Zé Domingos, parente das vítimas, conta a versão que ouvira de seus antepassados:

Antes de eu nascer, já tinha perturbação pela terra, já! Porque, olhe bem, no [ano de] 39 -39! - um cidadão tinha uma terra do travessão pra lá (...), ele sabendo que era pra lá. Pois, se queria fazer alguma coisa, por que não fez pra lá? Na parte que ele tava sabendo que era dele? E ele não botou pra cá? Pra dentro da área indígena? Fez uma casa de farinha pra fazer as farinhada das roças. Aí, no tempo do inverno pouco, as água dificultava e ele era criador de gado e os caboclos véi o que criava era as outras criação, era o porco, o animal, a ovelha, o bode, não criava gado... Aí ele proibia os porcos de irem mexer na água, porque porco é porco, né? E vivia já querendo vir pra cá, invadir pra cá, pra dentro da área indígena. Aí o que que aconteceu? Eles se juntaram - um grupo aqui da Passagem Rasa, da lagoa Seca e da Almofala - foram lá e tocaram fogo na casa de farinha dele, derrubaram e aí começou a guerra, começou a questão. (...) Eu nasci no 46 , mas eu conto porque os que morreram contavam, porque pra quem nasce no 46 e a história é do 39, né?... Api então, caminharam três anos pro Acaraú, pras 
audiência lá, no Acaraú, e vieram vindo, vieram vindo, quando foi no 42 foi que eles ganharam a questão, pra retirar ele da área indígena. No 42 já! Com três ano, né? Viajando com fome, viajando nu, porque o pessoal hoje diz "ora, não são índios, porque não andam nu." Mas nesse tempo, eu imagino que fosse pouca roupa, porque eu alcancei gente andando com pouca roupa. $E$, desse tempo aí pra cá, veio vindo, veio vindo e, depois, eles passaram uma cerca por cá das terras deles, no 62, até que aconteceu que morreu os três inocente que eles mataram. Porque eu considero que eram inocentes, os três que morreram e os outros que escaparam. Porque tem aquela história de dizer assim, quem vai pela cabeça dos outros é piolho. Eles foram pela cabeça dos outros. O Padre Aristides deu a garantia de ser por eles e, quando foi na hora, não agiu e aconteceu isso... [faz uma pausa e chora um pouco] Eu me emociono porque eu posso dizer que poderá ter sido maior tristeza, que foi o dia que eu vi os três meu tio morto pela terra. Finado Domingos, meu pai, não foi, se defendeu e outros também não foi... Então eu posso dizer que, pra nós, a guerra nunca findou. Continua. Continua, mas a gente pensa, fica pensando... (...) eu lembro que o meu pai dizia assim, a história dele era essa: a terra do aldeamento um dia vai ser tirada [tirada dos posseiros, em favor dos índios]. Se eu não alcançar, um filho meu alcança ou um neto. E eu, hoje, a mesma história. Ninguém sabe quando. Mas a fé não é viva, não é morta, como a fé do meu pai, que era viva! Pois é... mas eu sempre tenho aquele sentido comigo, todo brasileiro é descendente, pode dizer que é descendente, mas ter aquele sentido e aquela coragem de se identificar, e chegar em qualquer canto e contar a história, não é fácil não. A pessoa ser ameaçado de cara a cara, como eu tô aqui com você?... Dizer assim "o Zé Domingos é índio, ele tá merecendo é um tiro na cara!". A pessoa escuta uma coisa dessa, como é que fica? Como é que fica? Precisa Deus dar força àquela pessoa! Precisa Deus tá com aquela pessoa. E é o que aconteceu comigo lá naquela rua do Itarema. E eu fiz só olhar assim de lado e passei, pronto! (...) O trabalho da nossa luta dá pra rir e dá pra chorar, porque a gente não vive só de alegria. A gente vive, às vezes, mais de tristeza do que de alegria. (...)

Ouvi Seu Zé Domingos contar essa história repetidas vezes. Todas elas marcadas por forte emoção. Em uma das nossas conversas, enquanto chorava pelos seus parentes mortos, explicou-me que é importante chorar pelos entes queridos, ninguém deve ter vergonha de chorar pelos ancestrais que se foram, pois é assim que se demonstra afeto, respeito, além de ser uma forma de não os deixar cair no esquecimento.

Outra observação importante sobre seu relato é que a data aludida por ele é de um ano após a criação do cartório do Acaraú. Pelos relatos que tenho colhido em campo, foi a partir de então que se deu início ao processo de cercamento das terras da Almofala dos Tremembé. A cada 
cerca levantada eclode um novo conflito agrário. Praticamente todos os habitantes têm histórias para contar sobre posseiros que levantavam cercas em terras que eram de uso comum das famílias indígenas.

\section{Efeitos do agronegócio do coco}

Tal situação se agravou seriamente no final dos anos 70, quando duas empresas de beneficiamento de coco se instalaram em Almofala e reivindicaram a posse de mais de um terço do que atualmente é a AI. Alguns anos depois, as duas empresas fundiram-se e transformaram-se na maior empresa do ramo na região. Atualmente, a Ducoco representa o maior entrave jurídico à demarcação da AI Tremembé.

Contam-se muitas narrativas dramáticas sobre a época da instalação da empresa. Atraídas pela possibilidade de venda do coco à empresa, que compra até hoje a maior parte da produção local, as famílias influentes da região começaram a registrar os terrenos em seus nomes, desconsiderando as pessoas que ocupavam, cuidavam e viviam do trabalho nas terras. As famílias de agricultores eram expulsas violentamente das terras ou, quando não, precisavam submeter-se às precárias condições de trabalho que Ihes eram impostas pelos posseiros, os quais, tendo o respaldo legal do registro das terras, contavam não só com o apoio da polícia local, como mantinham também milícias particulares. Os tradicionais habitantes da área, por sua vez, até então não tinham a menor necessidade de registrar suas terras, pois, como já ressaltado, não se vislumbrava a possibilidade, - concordemos, um tanto absurda - de pessoas "de fora"48 tomarem as terras que haviam sido trocadas pela Santa.

Até a instalação da empresa, as plantações de coco serviam apenas para uso doméstico, pois muitas comidas são temperadas com coco, como cuscuz, tapioca, peixe e até mesmo feijão. Entretanto, obviamente, não era necessária a plantação de vastos coqueirais para dar

48 É assim que os Tremembé chamam as pessoas que não compõem a comunidade. 
conta das necessidades alimentares do grupo. As famílias só tinham, portanto, alguns poucos coqueiros plantados nos terreiros. Em muitas das vezes que visitei a Lagoa Seca com a Dijé, ela identificava facilmente a localização da casa de sua avó Chica, pelas árvores que as cercavam e continuam de pé. Alguns desses coqueiros, sendo mais altos que os demais, denunciam sua idade e os mais antigos se destacam em meio aos coqueirais plantados mais recentemente, que devoram as matas e tomam conta das paisagens locais.

Com o advento do comércio do coco na região, acontecia de muitos moradores começarem a comprar coqueiros uns dos outros. Esses relatos são muito comuns entre os habitantes. Começavam comprando um coqueiro e, posteriormente, iam cercando os coqueiros e ampliando as cercas. Assim, os moradores que não tinham dinheiro para comprar arames, estacas e cercar os terrenos viam suas roças serem engolidas pelas cercas alheias que delimitavam as plantações de coco.

Com a intensificação dos conflitos agrários, muitos moradores da Grande Almofala começaram a se organizar em sindicatos rurais, mais tarde, com o apoio das Comunidades Eclesiais de Base, da Associação Missão Tremembé e o contato de algumas lideranças do movimento com grupos indígenas no Nordeste do Brasil que - mesmo contrariando a premissa de que os índios da região já estariam "acaboclados" ou "aculturados", misturados às populações não índias - exigiam do Estado a posse definitiva de suas terras, fundamentando seus argumentos em critérios étnicos.

Desde o início dos anos 1980, portanto, os Tremembé de Almofala ganharam visibilidade no cenário político do Ceará, sendo um dos grupos pioneiros no movimento indígena no estado, que obtiveram atendimento de algumas de suas reivindicações, como saúde e educação diferenciadas. Entretanto, como anunciei na introdução, a demarcação das suas terras, por várias razões, continua sendo o maior entrave na luta, sobretudo pela pressão da Ducoco. 
No início dos anos 1990, o início do processo para demarcação impulsionou a luta, pois, pela primeira vez, o grupo se via diante da possibilidade de garantir a posse definitiva das suas terras. Contudo, após a publicação do Relatório de Identificação e Delimitação no Diário Oficial da União, a Ducoco conseguiu uma sentença em primeira instância e impediu a continuidade do procedimento. Desde então, já foram elaborados três laudos antropológicos sobre o grupo, dois dos quais foram contestados juridicamente. Sobre o terceiro, ele foi entregue ao STF recentemente e ainda não há resposta sobre a continuidade do processo.

\section{Atual cenário em Almofala dos Tremembé}

Em julho de 2013, retornei a Almofala para a primeira etapa de pesquisa de campo de doutorado, após um ano e meio longe. Como sempre, a primeira área por mim visitada foi a Praia de Almofala, centro do distrito, pois este é o destino final do ônibus que sai de Fortaleza. Nessa localidade, conforme já havia apontado no projeto, as mudanças na paisagem se intensificaram bastante nos últimos anos, muitas áreas que eram totalmente "no aberto" estão enchendo-se de cercas, casas, entre outras construções.

Em 2002, quando conheci a comunidade, a maioria das casas ainda era de taipa com os telhados cobertos de palha de coco, muitas delas ainda eram totalmente de palha - parede e teto - tendo como piso a própria areia da praia. As casinhas de palha são bem pequenas e guardam uma aparente fragilidade, embora as paredes de palha sejam firmes e protejam da ação da chuva e do vento. A palha tem a capacidade de manter a temperatura mais quente no interior das casas, assim, mesmo quando chove e venta intensamente, o calor dentro das casas as torna acolhedoras e aconchegantes. Quando os telhados as paredes estão em bom estado, mesmo sendo totalmente de palha, impedem vazamentos ainda que chova bastante. 
Atualmente, a quase totalidade de casas recém construídas é de alvenaria. Isso muda muito a paisagem, pois, diferente das casas de palha, que, conforme a necessidade, eram desmontadas e reerguidas em outro lugar, as casas de alvenaria são "fixas", e vão dando à paisagem formas de arruamento. Há pouco menos de uma década, as construções de alvenaria pelos índios da região da Praia eram raras, pois o custo era muito alto e havia poucos depósitos de construção na cidade. Nos últimos anos, o acesso aos materiais de construção tem se tornado mais fácil, pois os depósitos se multiplicaram no centro de Almofala. Alguns projetos como o Pró-Moradia, voltado para a urbanização de áreas carentes e gerido pela Prefeitura Municipal de Itarema, financiam a construção de casas populares em regime de mutirão e, deste modo, também impulsionam a proliferação de edificações de alvenaria. Outro fator importante ligado à construção de casas de alvenaria é a proibição da retirada de madeira do mangue, com a qual se construíam as casas de taipa e palha. ${ }^{49}$ Por fim, a preocupação com a segurança das casas, já que as casas de taipa e palha são frágeis e podem ser roubadas com facilidade, também leva os habitantes a darem preferência às construções mais sólidas. Esta preocupação também é recente, pois os números de roubos às casas têm aumentado muito nos últimos anos. Quando conheci a área, isso me chamou muita atenção. Na casa onde me hospedava - da Dijé - as pessoas não tinham a preocupação com roubos, que eram muito raros. Não mantinham suas casas fechadas nem mesmo quando saíam e, se a fechavam durante a noite, enquanto dormiam, era para se protegerem tão somente do vento forte da beira da praia. Mesmo nas casas de taipa, as portas e janelas eram de palha, não oferecendo resistência alguma a quem as quisesse abrir.

Em muitas localidades, a maioria das edificações foi erguida nos últimos quinze anos e ainda não houve nenhum trabalho que retratasse a forma pela qual os Tremembé estão reordenando essas áreas diante da possibilidade de construções mais sólidas e fixas. É essencial para esta

49 Para saber mais sobre a legislação ambiental sobre manguezais, ver a Resolução do CONAMA no 303/02, que versa sobre as Áreas de Preservação Permanentes. 
pesquisa saber, portanto, como eles estão rearranjando seus recintos residenciais nesse contexto de proliferação de construção casas de alvenaria, que dão um aspecto urbano à paisagem.

Os utensílios domésticos são compostos de objetos industrializados, sobretudo feitos de plástico e alumínio, mas, em muitas das cozinhas, há também objetos feitos manualmente. Embora esses artefatos sejam mais raros, pois os industrializados são mais baratos e acessíveis para a maioria, ainda há muitos artesãos que fabricam produtos tanto para uso próprio, como para venda - como conchas feitas com coco ou cabaças e louças de cerâmica... Os objetos industrializados são comprados no centro comercial de Itarema ou nas portas das casas, pelos galegos - figuras muito populares em todo o interior do Ceará e nas periferias de Fortaleza, que passam nas portas vendendo variados artigos, em geral utensílios domésticos feitos de plástico e alumínio, como pratos, talheres, panelas, cadeiras, lençóis, redes de algodão... Em todas as casas onde eu me hospedei, recebia, de manhã cedinho, a visita do galego, que passava sempre cobrando suas prestações e oferecendo novos produtos. Seus preços são bem mais altos do que os do mercado, mas oferecem algumas "facilidades" de pagamento, pois vendem tudo em prestações bem baixas e acessíveis às famílias de baixa renda. Os mais velhos, que têm mais dificuldade de se deslocar à Sede do Município, são fregueses assíduos, também pelo fato de a maioria deles ter aposentadoria. Muitas donas de casa, além de comprarem os produtos, ficam com alguns deles em regime de consignação, para tentar vendê-los na vizinhança e conseguir uma pequena renda extra.

Já os produtos comprados nas lojas do centro são os mais variados, desde pequenos artigos para casa a eletrodomésticos que são vendidos, em geral, a prestações no crediário. Muitos índios conseguem através da comprovação da renda, mesmo sendo elas bolsas advindas de programas sociais - crédito nas lojas para comprar produtos a prestação. Entretanto, nem sempre eles têm conhecimento sobre a burocracia que envolve tais compras. Posso citar como exemplo um caso relatado a mim 
por um rapaz que comprou uma bicicleta em uma loja no centro e, logo nos primeiros meses de uso, o produto apresentou um defeito. Ele então se dirigiu à loja com o objetivo de trocá-la por uma nova. Como não obteve êxito, resolveu deixar a bicicleta na loja e cancelar a compra, contudo, esta proposta também não foi aceita pelos vendedores, que o explicaram que não aceitariam o cancelamento. Ainda assim, ele deixou a bicicleta na loja e voltou à sua casa. Qual não foi sua surpresa ao, no começo do mês seguinte, receber novamente a cobrança do crediário e perceber que sua conta ainda continuava em aberto! Ele, entretanto, não se dispôs a pagar e me disse, com conviç̧ão, que não devia nada a ninguém, pois havia devolvido o produto e, por isso, não pagaria as demais prestações. Ou seja, na sua concepção, tais operações se desenrolam no âmbito da informalidade e das relações pessoais que têm mais valor do que procedimentos burocráticos. Muitos casos semelhantes me foram narrados. Há várias pessoas que realizam transações bancárias - como empréstimos consignados ofertados por bancos e seguradoras, especialmente aos aposentados - mesmo sem ter ideia do funcionamento dessas transações, assim, acabam se endividando e pagando altas taxas às empresas.

A possibilidade de compras a prazo, aliada a chegada da energia elétrica, aumentou consideravelmente a procura a eletrodomésticos. Produtos como geladeira e televisão são presentes em praticamente todas as casas. As máquinas de lavar roupas não são tão comuns como os dois primeiros, mas estão entre os artigos mais desejados pelas donas de casa que, tendo geralmente uma numerosa prole, passam muito tempo a lavar roupas no tanque, inclusive as pesadas redes de algodão, usadas por praticamente todos ali. Raramente alguém dorme de cama, as pessoas de todas as idades dormem de rede, este costume, aliás, é comum não só entre os Tremembé, mas em todo o Ceará.

Até o ano de 2008, muitas áreas, inclusive na região da Praia, centro do distrito, ainda não tinham energia elétrica. O Programa Luz Para Todos, do Governo Federal, levou energia elétrica para muitas regiões que, há muito, reivindicavam esse acesso. A água encanada também veio mais 
ou menos na mesma época, até então, as residências eram abastecidas por poços profundos que tinham manivelas manuais de onde se puxava água para banho e lavagem de roupa. Em muitas das casas mais próximas à beira da praia, as águas dos poços eram impróprias para o consumo, pois era uma água saloba -ou seja, salgada - como me explicavam os Tremembé. Muitas famílias buscavam água para beber e cozinhar a quilômetros de distância de suas casas.

O acesso aos serviços de internet e telefone celular não é tão amplo como os de água e luz. Somente duas operadoras de celular funcionam na Sede do Município e, nos distritos, é preciso ter uma antena especial para conseguir acesso a telefone celular. Os serviços de internet também exigem uma antena especial, mas elas são mais comuns do que as de celular. Nas escolas indígenas também há acesso à internet, embora o serviço seja demasiadamente lento. Ainda assim, muitos membros do grupo têm acesso à rede, perfis nas redes sociais como facebook e whatsapp. Diante de tantas transformações ocorridas com a chegada dessas novas tecnologias, é preciso verificar a forma como - frente às novas possibilidades de acesso à moradia e a sistemas de água, esgoto, eletricidade e internet - os Tremembé vêm reorganizando seu cotidiano e seus lugares.

Nesse processo de reordenamento dos lugares, há muito mais a considerar do que a urbanização da área. Muitas áreas estão sendo desmatadas não só para dar lugar a novas construções, mas também a plantações de coco. Tais mudanças são tratadas nas narrativas sobre os encantados com certa preocupação, pois uma das consequências delas é que as moradas dos encantados estão se restringindo e, em algumas áreas, correndo o risco de desaparecerem por completo.

No início da pesquisa de campo do doutorado, dentre todas as mudanças nas paisagens, o que mais me chamou atenção foi a construção de uma enorme casa de veraneio num terreno que era propriedade de Seu Raimundo Grande, índio Tremembé e pescador recentemente falecido com mais de 90 anos. Ele morava com a família em um terreno bem próximo ao 
mar, onde ele tinha sua casa e uma área dedicada a uma roça, um pequeno pomar e a criação de porcos e galinhas. Por decisão própria, ele vendeu seu terreno a um desconhecido ${ }^{50}$, que rapidamente construiu não só a casa, mas uma grande muralha em volta de todo o terreno ${ }^{51}$. A construção chama atenção diante da inexistência de muros na área, onde os terrenos são delimitados por cercas, a maioria delas, inclusive, também erguidas recentemente. Quando, tomada pelo espanto, fui investigar as condições de "venda" do terreno, constatei que tal prática tem sido recorrente em Almofala. $\mathrm{O}$ argumento de Seu Raimundo foi que precisa assegurar um lugar para seus filhos e netos, já que, diante da incerteza da demarcação, eles não têm a garantia de um lugar para viver futuramente. Com o dinheiro da venda, ele pôde comprar uma casinha no centro do distrito e conseguiu ajudar um neto na compra de um carro utilizado para realizar fretes, constituindo uma importante fonte de renda para o orçamento de toda a família. Embora esta seja a edificação que mais chama atenção, pela sua grandiosidade e pela muralha que a cerca, outras construções menores também vêm sendo erguidas por moradores "de fora".

Ou seja, a posse das terras continua se efetivando, em geral, por meio de compra e venda. Vale destacar que os terrenos são vendidos por um valor bem abaixo do valor de mercado em áreas litorâneas do Ceará, já que, estando a terra em processo de demarcação, ela perde o valor comercial.

Muitos índios revelam que só possuem um lugar para viver hoje porque conseguiram comprar o terreno de terceiros, muitas vezes pessoas "de fora". Isto demonstra que, a ausência da FUNAI, a desinformação sobre

\footnotetext{
50 Pouco se sabe sobre o comprador do terreno, somente que é paulista e que a compra foi intermediada por um morador da região cuja família se coloca veementemente contra a luta dos índios pela demarcação da terra. Tal morador, pouco tempo depois da venda do terreno, foi preso pela polícia federal, sob a acusação de envolvimento com tráfico de drogas e assaltos a banco, o que gerou um forte sentimento de desconfiança por parte dos índios em relação ao "novo morador". Embora morem na casa somente o comprador e sua companheira, a movimentação de carros é intensa, o que aumenta a desconfiança e a insegurança por parte da vizinhança.

$51 \mathrm{O}$ terreno tem aproximadamente 1 ha, mas não posso precisar aqui a quantia pela qual foi vendido, pois não consegui ter acesso a tal informação.
} 
os preços do mercado imobiliário e a incerteza da demarcação da área têm alavancado o processo de espoliação e esbulho das terras entre os Tremembé. Como os terrenos, ainda que vendidos sem escritura, estão sendo comercializados e cercados, na ânsia de tentar garantir a posse das suas terras, os próprios índios se preocupam em cercar suas propriedades para evitar que elas sejam invadidas e cercadas por terceiros.

Esta constatação levou-me, nos meses iniciais da pesquisa, em centrar o foco das minhas investigações nas questões relativas à gestão da região da Praia52, onde permaneci durante os primeiros meses de campo. Uma das primeiras providências nesse sentido foi a realização de algumas reuniões com os alunos das escolas - mais precisamente as escolas da Praia de Almofala e do Mangue Alto -, onde eu pedia para que cada uma das crianças desenhasse suas casas individualmente, e, posteriormente, em grupo, desenhassem suas respectivas comunidades. Com essa atividade, meu intuito era saber qual percepção os alunos tinham daqueles lugares. Em praticamente todos os desenhos, quando eu pedia para retratarem suas próprias casas, as crianças desenhavam o que chamavam de "nosso cercado", onde constavam as casas de vários membros da família. Alguns deles, inclusive, iniciava a gravura pela cerca, desenhada nas bordas do papel. No interior das cercas, é retratada a casa da avó, geralmente maior que as outras e mais uma ou duas casas, quase sempre de seus pais e tios que, na medida em que vão casando, vão construindo casas nos terrenos dos pais. Quando desenhavam as comunidades, uma pergunta frequente era "temos que desenhar também as cercas?". Isso porque, desenhá-las tomava muito tempo, devido à enorme quantidade delas ${ }^{53}$.

Mesmo sendo a maioria das casas construídas de alvenaria, em muitas delas há um pequeno compartimento de taipa ou palha que serve de

\footnotetext{
52 Concentrei-me, mais precisamente, nas localidades da Praia de Almofala, Mangue Alto, Panã, Lameirão e Passagem Rasa. Mas, desde as minhas primeiras incursões em campo, ainda na graduação, fico hospedada na casa da Dijé, agente de saúde indígena e importante liderança, que se tornou uma das minhas principais interlocutoras desde então. Ela e a família (seu irmão é cacique) são pioneiras na organização política dos Tremembé. ${ }^{53}$ Alguns desses desenhos podem ser vistos em anexo.
} 
cozinha e abriga um pequeno fogão a lenha - alternativa para o fogão a gás, quando não se tem dinheiro para comprar um novo bujão. Há também, muito comumente, pequenas barracas de palha nos terreiros, onde são armadas as tucuns - redes de dormir que, apesar do nome, nem sempre são feitas de tucum, muitas delas são de tecido, retalhos ou redes de pesca. Elas fazem as vezes de "sala de visita", pois são prontamente oferecidas aos visitantes e embalam as conversas vespertinas entre os parentes e vizinhos.

Este exercício levou-me a algumas reflexões sobre a organização dos recintoss residenciais entre os Tremembé, tais como: quais os elementos contidos nesses cercados? Como eles são habitados, coletivemente, pelas famílias que os compõem? Qual a relação entre os vizinhos? Na maioria dos cercados, além das casas há criação de galinhas, porcos e, no caso dos cercados um pouco maiores, há também ovinos e caprinos. Em alguns deles, quando há espaço, há também pequenas hortas e jardins, cuidados, em geral, pelas mulheres. Já as roças, situadas nos terrenos maiores, estão mais concentradas nas áreas das Matas e são responsabilidade, sobretudo dos homens, não obstante a manutenção das mesmas seja uma tarefa que envolva toda a família.

Embora sejam espaços de uso individual de cada família, a relação que os índios estabelecem com os cercados uns dos outros é, evidentemente, bem diferente daquela estabelecida com os cercados dos moradores "de fora". É comum eles entrarem nos cercados de vizinhos para pegar frutas - principalmente caju54 e coco seco, usados como tempero nas

${ }^{54} \mathrm{O}$ caju é uma fruta muito importante não só para a dieta entre os Tremembé, como tem uma relevância simbólica muito grande, pois é do caju azedo que se faz o mocororó, uma espécie de vinho de caju, que, após espremido é guardado em um recipiente hermeticamente fechado, onde ele fermente e depois é consumido. Esta bebida é um elemento chave na dança do torém. A dança constituiu, desde o início da organização política, o principal elemento de diferenciação para os Tremembé. Os outros grupos indígenas cearenses dançam o toré, mas a dança do torém é praticada somente pelos Tremembé. A dança constitui na formação de uma roda, no centro da qual ficam os mestres ou puxadores do torém que cantam as músicas e balançam a maracá, enquanto os demais participantes giram no sentido anti-horário. No centro da roda, também fica um grande recipiente contendo o mocororó, que é consumido pelos participantes ao longo da dança. Sobre o torém, uma importante referência é a dissertação de mestrado de Oliveira Jr 
comidas - ou para se deslocarem através dos mesmos de um lugar a outro. As pessoas "de fora", todavia, muitas vezes, interditam a passagem de índios pelos seus terrenos, sendo necessário que eles façam longos desvios para se deslocarem a lugares que antes eram de bem fácil acesso. Esta interdição, entretanto, nem sempre é respeitada e muitas pessoas, sobretudo as crianças, continuam a fazer seus percursos por dentro de terrenos que, atualmente, estão sob a posse de não índios. Sobre isso, as crianças contam com humor as "aventuras" às quais se lançam para pegarem alguma fruta ou se deslocarem por esses espaços, mesmo à revelia dos posseiros que ameaçam, xingam e, em alguns casos, chegam a soltar cães de guarda para afastá-las. Suas "aventuras", entretanto, nem sempre terminam em simples brincadeiras e fugas "divertidas", pois não raro, as ameaças são cumpridas. Casos violentos envolvendo as disputas pelos terrenos e os recursos que eles dispõem são muito comuns não só nos terrenos da Ducoco, mas de muitos outros posseiros que invadem terrenos situados na Área Indígena. No depoimento abaixo, Babi - uma liderança do movimento de quem já falei no capítulo anterior - conta um caso envolvendo seu filho que, após uma pescaria de camarão, passava por dentro de um terreno invadido por um posseiro conhecido na região.

O irmão do Agostinho Pereira açoitou ele, bateu nele, né? Ele vinha da pescaria, negócio de 4 e meia da tarde, ele vinha da pescaria, ele andava pescando com o irmão dele no lagamar, pescando camarão. Aí, quando vinha de lá pra cá, passavam por dentro do cercado dele, tinha um caminho que passava por dentro do cercado, mas era o caminho que todo mundo andava. Aí eles vinham por lá, onde tinha um córrego que eles (...) pra tomar banho. No outro dia, quando ele chegou... aí ele andava com o irmão dele...o irmão dele, quando o cara pegou... Aí, no córrego que ele (...) no córrego pra tomar banho, aí tava esse cabra, Tomás, Tomás Pereira, aí tava no córrego, aí disse assim, "Ei, eu quero comprar camarão, esse camarão ta pra vender?" Aí o meu menino falou, o Fábio falou "Não, a gente traz pouco, mas tu queria o quê?" "Eu queria só um litro." Aí conversando com o menino numa boa, ninguém não tinha dúvida nenhuma sobre eles, não. Aí o meu menino foi-se... pegou, botou o

(1997), embora outros trabalhos também falem sobre a dança, como Valle (1997) e Messeder (1995) (2004). 
uru no chão, foi tirar o camarão, quando o menino se abaixou pra tirar o camarão, ele pegou o menino pelo braço... parece que, nessa hora que ele tava conversando com o menino, tava com a mão pra trás e o chicote na mão, chicote de relho, de açoitar, bater em animal. Aí ele tava com esse chicote na mão, o menino nem percebeu nada, viu ele com a mão pra trás, mas não esperou que ele tivesse nada na mão. Aí pegou o menino com um braço, começou a chibatear o menino com o outro. O menino apanhou mesmo pegado, sem ter como se defender e o outro, quando viu isso, correu... o outro, quando viu isso, correu, o outro irmão. Correu aí, quando chegou em casa tava eu e o Antônio tava em casa nessa hora, aí "papai, o Tomás ta batendo acolá no Fábio!" "menino e o que foi que vocês fizeram?" "nada não, não fizemo nada." Aí o Antônio botou pra lá, quando chegou lá... não chegou até lá, não, encontrou o Fábio já no caminho. Derramaram camarão nesse dia... quando ele chegou, do jeito que era as perna de relho, as perna do chicote, vinha nas costas dele tudinho, chega vinha assim, minando sangue. Aí, ai minha Nossa Senhora do Céu, aí o bichinho chegou chorando, ele tinha 14 anos nesse tempo... aí a gente nem foi cuidar desses camarão, nem foi cuidar de janta... balancemo pra praia, eu mais o pai dele, lá pro João Venâncio, falar isso aí com ele, aí, quando cheguemo lá, por sorte, quando cheguemo, o Florêncio tinha acabado de chegar de Fortaleza. Aí o Florêncio viu lá a arrumação, "Ave Maria, Antônio, tu vai viajar bem cedo com ele pra Fortaleza, ninguém vai caçar nada aqui. Você vai direto pra Fortaleza, lá pra federação." Aí arrumaram dinheiro, dera dinheiro a ele, no outro dia, ele viajou com o menino, chegaram com três dia. Aí lá andaram no hospital com ele, tirar corpo delito, foram não sei aonde, não sei aonde, foram na procuradoria da república... eu sei que ajeitaram lá e aí começou lá em Fortaleza e aí veio pra cá, as audiência começaram lá, mas aí, com o tempo, aí veio pra cá, porque com o tempo aí tinha o município aí, tinha fórum, aí começou a juntar com as audiência. Aí o Fabio foi... nesse tempo, o Fábio foi-se embora pra lá. A Fátima veio, irmã dele, morava lá e veio, aí levou ele pra trabalhar. Assim que ele chegou lá, se empregou numa padaria, começou a trabalhar. Aí era assim, quando era as audiência, aí ele vinha, ele vinha com o advogado que é o João Aciolly e voltava com ele mesmo. E nós ia pro Itarema, se encontrava com ele lá, aí ele ia s'embora, nós ia s'embora. Aí, quando foi com um tempo, ele começou a dizer "Ora, eu não quero mais isso, não..." mas já tava com muito tempo, agora ele já tem 24 anos, agora, nesse tempo, ele tinha 14.

O caso relatado acima aconteceu ainda nos anos 1990 . Desde então, os conflitos em torno da situação fundiária na região só têm se agravado. Na última década, vários outros atores têm entrado nas disputas por terra não só em Almofala, mas em todo o litoral cearense. Além do 
agronegócio do coco, outros empreendimentos têm agravado a situação de degradação dos ecossistemas litorâneos.

Para compreendermos as dinâmicas territoriais que se desenrolam atualmente na Almofala dos Tremembé, precisamos, portanto, ter noção dos projetos de desenvolvimento propostos para a região e, mais do que isso, das perspectivas políticas a eles vinculadas. Para tanto, abordarei o crescimento do agronegócio no litoral oeste do Ceará, que é um dos estados que mais produz a fruta no país. Segundo dados do Instituto Brasileiro de Geografia e Estatística (IBGE), o Nordeste concentra $81 \%$ das plantações de coco do Brasil, sendo a maior parte dessas nos estados da Bahia e Ceará. No caso deste último, a área mais atingida pelas plantações de coco concentra-se no litoral oeste, entre os municípios de Pentecoste, Paracuru, Paraipaba, Trairi, Itaipoca, Amontada, Itarema e Acaraú.

Atualmente, além de o agronegócio do coco, vários outros elementos entram nesse cenário, como os criatórios de peixe e camarão, o crescimento da atividade turística e - o que mais tem preocupado as lideranças políticas nos Tremembé nos últimos anos: as empresas de energia eólica.

Nas últimas etapas de campo, pude acompanhar essa luta de perto, tanto através do acompanhamento das reuniões do Conselho Indígena Tremembé de Almofala (CITA), como na $V$ Assembleia do Povo Tremembé, ocorrida em julho de 2013, na qual os debates acerca da degradação ambiental causada por esses empreendimentos deram a tônica do evento.

A construção de parques eólicos traz consigo uma série de transformações, talvez as mais intensas já vividas na área nas últimas décadas. Além dos próprios parques, há que se construir uma série de obras de infraestrutura que possibilitem as instalações dos aerogeradores. Tais obras incluem a construção de várias estradas que cortam rios e córregos 
e comprometem seriamente espaços essenciais para a sobrevivência dos Tremembé que ainda têm a agricultura e a pesca artesanal como elementos essenciais para o sustento das famílias.

Na minha penúltima etapa em campo, acompanhei as discussões sobre alguns empreendimentos que a Prefeitura Municipal de Itarema tem tentado construir, como uma ponte sobre o rio Aracati-Mirim, ligando as áreas da Praia e das Matas e uma estrada que liga a comunidade da Passagem Rasa à sede do município. Tais projetos provocaram muitas discussões entre os moradores das diferentes comunidades e foram tema de algumas reuniões do CITA, fato que me expôs algumas divergências entre as lideranças. Em relação à construção da ponte todos eram radicalmente contra, principalmente em razão do comprometimento da pesca no rio. A estrada, todavia, causou maior polêmica, pois, enquanto uns - sobretudo as lideranças da Passagem Rasa - eram radicalmente contra o empreendimento, sob o argumento de que - mesmo a estrada melhorando a mobilidade dos moradores - ela seria a porta de entrada para muitos outros empreendimentos, como as fazendas de camarão e os parques eólicos. Já outro grupo menor, mas que contava com importante lideranças, como o cacique e o pajé, argumentava que seria mais vantajoso, politicamente, conceder a construção da estrada, pois, além de ela facilitar o acesso à Passagem Rasa e às localidades próximas, seria uma estratégia de garantir o apoio do atual prefeito à reeleição do único vereador índio do Município.

As obras iniciaram mesmo sem o devido licenciamento ambiental e, mesmo no início da construção, elas já estavam provocando devastações como o aterramento de alguns trechos do rio, o que comprometia a atividade pesqueira, e o desmatamento de uma vasta área na localidade da Passagem Rasa. As lideranças indígenas, mobilizando os órgãos ambientais responsáveis, conseguiram determinação da justiça para parar as obras após a realização de uma audiência pública, em março de 2014, com a presença do Ministério Público, do Instituto Brasileiro do Meio Ambiente e dos Recursos Naturais Renováveis (IBAMA) e da Secretaria de Meio 
Ambiente do Ceará (SEMACE). Na audiência, os índios mantiveram uma unidade e decidiram que prevaleceria a decisão dos moradores da Passagem Rasa, por serem eles diretamente impactados pelo empreendimento. Posteriormente, à audiência, o Ministério Público estipulou um prazo de duas semanas para que a Prefeitura Municipal de Itarema retirasse a areia depositada no rio e de noventa dias para que apresentasse o plano de recuperação da área degradada na Passagem Rasa.

Mas nem sempre os casos de desrespeito à legislação ambiental têm esses desfechos. Ações de desmatamento são cotidianos e atingem áreas de proteção permanente como manguezais. As áreas de mangue são preferidas pelos criatórios de camarão em cativeiro, assim, de tempos em tempos, quando os viveiros são esvaziados, os criadores jogam ao rio a água contaminada por substâncias que matam a fauna dos rios, lagos e lagamares dos mangues e comprometem a sobrevivência das famílias que pescam cotidianamente nos lagamares, de onde tiram a base da proteína consumida pelas famílias. Como artigos como carne e frango são mais caros no comércio, a maioria das famílias consome peixes e crustáceos pescados por seus próprios membros. Ainda assim, precisam comprar outros alimentos, como arroz, feijão. Com a baixa produção agrícola nos últimos anos, compram até mesmo a farinha de mandioca. Antes, era comum dispor desse produto nas casas, pois a maioria das famílias tinha pelo menos um membro que trabalhava nas farinhadas da vizinhança e recebia pagamento em goma e farinha, que eram armazenadas e garantiam a principal fonte de carboidratos do grupo.

Os hábitos alimentares também mudaram muito na última década, já que a principal forma de acesso à comida atualmente é através da compra, não mais da produção. Assim, o consumo de alimentos industrializados aumentou significativamente. Quando conheci o grupo, o cardápio não variava muito no decorrer dos dias. Da manhã à noite comiase tapioca. A tapioca acompanhava o café tomado de manhã cedo e o peixe do almoço. Em praticamente todas as casas se almoçava peixe com tapioca ou farinha. A agricultura, entretanto, nos últimos anos, não tem atendido 
à demanda, encarecendo muitos produtos, até mesmo goma e farinha, cuja produção, até bem poucos anos, atendia a demanda das famílias.

Desta forma, às vezes os produtos industrializados saem bem mais em conta para as famílias que, além de precisarem comprar alimentos a baixo custo, ignoram muitos dos efeitos nefastos dos alimentos industrializados nos seus corpos. Não obstante alguns desses efeitos serem inegáveis, praticamente todas as pessoas com quem conversei a respeito dos hábitos alimentares atuais concordam que os casos de obesidade e diabetes se tornaram comuns em praticamente todas as famílias e eles são atribuídos ao consumo de alimentos raramente consumidos antes pelos membros do grupo, que consumiam basicamente durante todo o ano, além dos frutos do mar, feijão, milho e mandioca.

\section{$* * *$}

A preocupação com a atual configuração espacial da Praia de Almofala tomou conta dos meus primeiros meses de pesquisa e teve como saldo, além dos desenhos das crianças, muitas marcações em GPS dos percursos cotidianos feitos pelos índios para se deslocarem entre as localidades, observações, anotações e entrevistas sobre a organização dos espaços.

Na sistematização dos dados, percebi que, quando eu focava as entrevistas nas questões relativas às formas de ocupação dos lugares, os encantados raramente eram mencionados, ficando o assunto mais restrito às disputas pela terra, aos cuidados com as roças e à questão da demarcação. Entretanto, quando o foco das conversas caía sobre os encantados, apareciam os temas mais diversos, sobretudo os cuidados com o corpo e os espaços. Por isso, nas etapas seguintes do campo, resolvi centrar minhas investigações mais nos encantados do que nos espaços em si. Percebi que seria impossível compreender a gestão dos espaços chamados de moradas dos encantados sem antes centrar minhas investigações com mais minúcia sobre os próprios encantados. Precisava 
aprofundar meus conhecimentos sobre quem são tais entidades, como eles agem, de onde vem...

Sempre que falava da pesquisa com meus interlocutores, orientavam-me a procurar velhos pescadores e agricultores, pois seriam pessoas sabidas, que poderiam me dar preciosas informações sobre os mundos encantados. Deste modo, um exercício que me ajudou significativamente nas investigações sobre os encantados foi a ampliação da área de estudo para as localidades das Matas, pois sendo a atividade agrícola mais intensa nessas localidades, pude perceber como esta atividade está ligada à presença de encantes, portanto foi de extrema relevância atentar para o preparo das roças que ocorre na segunda metade do ano.

Em relação à pesca, como a pesca no mar é uma atividade eminentemente masculina, seria muito difícil para mim, acompanhar o cotidiano dos pescadores homens. Por isso, acompanhei somente as pescas nos lagamares e manguezais, realizadas pelas mulheres. Nesse momento, julgo necessário discorrer mais acuradamente sobre a agricultura para que possamos ter noção de como as disputas territoriais estão impactando essa atividade e, deste modo, comprometendo a sobrevivência das famílias de agricultores.

\section{Algumas considerações sobre a atividade agrícola entre os Tremembé}

As disputas territoriais atingem expressivamente a atividade agrícola, que necessita de amplas áreas de terra para se desenvolver. Como as áreas plantadas necessitam de um repouso de tempos em tempos, por causa do esgotamento do solo, isto coloca os agricultores diante de um impasse: onde plantar quando o solo se mostra esgotado para mais um ano de plantação? Muitas vezes é necessário plantar em terrenos de mata virgem, como os Tremembé chamam as áreas onde há abundância de vegetação "nativa", que são brocadas para servir às lavouras. Assim, muitos dos indivíduos que se lançam a esta atividade, sofrem retaliações por parte 
dos encantados, pois ela afeta diretamente as suas moradas. Como já mencionei, são muitos os relatos de agricultores que, ao brocarem terrenos, são repreendidos por entidades que aparecem para assombrá-los ou jogarem-Ihes feitiços, sendo necessário, em muitos casos, recorrerem aos pajés para livrarem-se dos tormentos.

Os principais produtos plantados pelos Tremembé são o feijão, o milho e a mandioca. Este último é o mais importante deles, pois a farinha e a tapioca constituem a principal fonte de carboidratos para o grupo. Em menor escala também há plantações de frutas como jerimum, melão e melancia. Tais produtos servem, principalmente, para consumo próprio das famílias, mas, evidentemente, o excedente da produção é vendido e, nos períodos de colheita, contribui significativamente para a renda familiar.

Nos quatro últimos anos, a região - não só o Ceará, mas todo o Nordeste - vem atravessando um severo período de estiagem apontado pelos especialistas como o pior dos últimos cinquenta anos. Por isso, muitas das plantações têm sucumbido à seca e a produção, na maioria dos casos, não tem sido suficiente nem para o consumo das famílias, muito menos para a venda.

Das frutas, o caju e o coco representam uma renda mais expressiva. Os cajueiros são abundantes, pois se trata de uma fruta nativa da região que resiste, inclusive aos períodos de seca prolongada. Muitas famílias colhem castanha de caju e as vendem para complementar a orçamento doméstico. Já as plantações de coco, que constitui uma espécie exótica, têm competido de forma desleal com a vegetação nativa.

Por conta da instalação da Ducoco, e a consequente garantia da compra de toda a produção do fruto, as plantações de coco têm tomado conta das paisagens locais, principalmente das regiões da Praia, Varjota, Tapera e Batederia. Isso é visto com muita preocupação por algumas lideranças que reclamam das consequências do incremento da monocultura do coco. Segundo eles, como o coco absorve muita água, as grandes plantações contribuem para o esgotamento das reservas de água, além de colaborarem também com o ressecamento do solo. No depoimento a seguir, 
Manuel, agricultor e morador da Passagem Rasa, interlocutor sobre o qual já falei nos primeiros capítulos, esclarece esta questão:

É, aqui [referindo-se à localidade da Passagem Rasa] tem menos coqueiro. Nos outros canto tem muito mais. Porque nós, índio mesmo, nós não se interessa muito por coqueiro, porque o coqueiro ele já faz parte do branco, é uma grande parte do branco e nem é tanto por isso, é por causa que o coqueiro, ele acaba com a terra, um pé de coqueiro, ele acaba com a terra. Um coqueiro, você planta ele aqui, com dois ou três anos, ele tem tomado de conta dessa área aqui todinha. A raiz dele tem tomado de conta, e adonde pertence aquela raiz dele ali, aquela terra ali ta morta. Porque adonde ele vai, ele acaba, porque ele vai tecendo por baixo aquela raiz dele, aquela raiz dele é seca e você vai plantar ali, você pode plantar, pode adubar, mas aquela raiz dele ta lá, ela chupa o adubo todim. Ela puxa o adubo, puxa água, aquele chão fica ressecado, o que você plantar ali não nasce nada. Você pode andar numa firma dessa aí que é a coisa mais feia do mundo, a sequidão, aquilo ali acaba com a terra. Eu bem podia ter plantado aquela região ali todinha de coqueiro, lá mais pro alto, podia ter plantado aqui, mas eu não plantei, plantei só uns quatro pézim ali assim. Só mesmo ali pra ir bebendo a água do coco e temperando, não plantei muito. Já o cajueiro não, o cajueiro fortalece a terra, porque ali, aquela folha dele cai, aquela folha dele é o adubo. As vez a gente pega até a folha do cajueiro, a folha podre e faz o canteiro e planta, faz a hortazinha, planta a cebola pra temperar, porque a folha do cajueiro é um adubo, muitas vez a gente pega a folha do cajueiro o bota no tronco de um coqueiro, de uma bananeira... porque ele tem um paú, ele tem um adubo... o coqueiro não, ele faz é destruir, acabar com a terra, e o cajueiro, ele faz é levantar, fortificar a terra, a folha dele. Por isso todos os anos eu pego o cajueiro, quando eles tão com os galhos baixos, eu corto e alevanto e pego os galho tudim e faço monte, ou nos tronco dos coqueiro ou em algum lugar diferente... É por isso que a gente dá mais valor ao cajueiro, mesmo a produção dele sendo só de ano em ano. O coqueiro não, de 3 em 3 meses você tem o coco, se o coco tiver bom, você faz um bom dinheiro, mas por outro lado tem isso. O cajueiro é só de ano em ano, mas a gente prefere ele por dois motivo, ele aduba e terra e dá lenha, porque ele fronda muito e a gente poda e tira a lenha.

Nas caminhadas por entre as matas de Almofala, com Manuel e seu pai, Seu Zé Domingos, pude perceber uma praga que se está alastrando por entre a vegetação nativa e tem contribuído drasticamente para a diminuição da safra de frutas como o caju e a seriguela - a cochonilha. A hipótese de Seu Zé e de muitos outros agricultores é que as "pragas" se alastram por conta do uso de agrotóxicos pela Ducoco, que as vão tornando mais resistentes. Numerosos agricultores com quem conversei queixavamse da proliferação da cochonilha, e muitos deles diziam que só haviam 
conhecido a "praga" recentemente, e, por isso, sequer sabiam nomeá-la, apenas se referiam a uma "lêndea branca" que se estava espalhando e matando as frutas nativas e as plantas ornamentais.

\section{$* * *$}

Há dois momentos durante o ano em que se levantam roçados. $\mathrm{O}$ primeiro deles é entre os meses de janeiro e fevereiro, pois, como o inverno ${ }^{55}$ começa geralmente no mês de março, os dois primeiros meses do ano são dedicados ao preparo das roças para receberem as chuvas. Já no mês de agosto, quando cessa o inverno, se plantam nas terras molhadas, chamadas pelos índios de baixas, situadas nas margens dos rios e lagoas. Devido ao clima semiárido, os demais terrenos secam rapidamente após o período de chuvas. As plantações das baixas devem ser colhidas até janeiro seguinte, pois, caso as chuvas reiniciem antes da colheita, elas brejam, ou seja, encharcam e ficam impróprias para o consumo. Como estas roças são colhidas em apenas seis meses, elas não dão a mesma produção que as roças plantadas no início do ano e têm como objetivo apenas o consumo doméstico.

No caso do feijão e do milho, o ciclo entre o plantio e a colheita é mais rápido, constituindo um ciclo de, aproximadamente, três meses. Já as roças de mandioca demoram um ano e meio para serem colhidas. Depois da colheita, a mandioca é trazida em burros ou jumentos até as casas de farinha, onde se inicia o processo de transformação da mesma em alimento. É no interior das casas de farinha que se desenrolam as farinhadas, procedimento no qual se produzem farinha e goma, base alimentar do grupo. As farinhadas ocorrem entre os meses de julho e outubro, nas localidades da Tapera, Varjota e Passagem Rasa, onde há mais plantações

55 No Ceará, de um modo geral, utilizamos a palavra "inverno" para falar da estação chuvosa. Esta estação não é caracterizada por uma alteração na temperatura, somente por chuvas, às vezes bem intensas. Quando se fala, por exemplo, que um ano teve um "inverno bom", significa que choveu bastante durante esse ano. 
e algumas casas de farinha, entretanto, uma dificuldade que os índios têm enfrentado é que nenhum membro do grupo possui casa de farinha, então eles precisam alugar as casas de terceiros para processarem a mandioca. O que tem complicado a produção é o fato de muitos dos donos de casas de farinha proibirem o aluguel das casas aos índios, por causa das disputas territoriais. Ainda assim, pude acompanhar algumas farinhadas em casas alugadas pelos índios. Na localidade do Saquinho, há uma casa de farinha construída através de um projeto social ${ }^{56}$ para a comunidade. Também tive oportunidade de vê-la em funcionamento algumas vezes.

As casas de farinha são galpões equipados com os acessórios necessários à farinhada - processo de transformação da mandioca em alimento. São eles:

Facas, facões e caçuás (cestas de cipó utilizadas para transportar a mandioca) - utilizados no transporte e na raspagem da mandioca.

Caititu - instrumento elétrico formado por várias serras em cilindro que trituram a mandioca depois de raspada. Antigamente, a engrenagem era girada manualmente, hoje, embora ainda haja alguns manuais, a maioria dos caititus são elétricos.

Tanques e peneiras - onde a mandioca fica de molho, e, em sequência, é espremida pelas mulheres.

Prensa - depois de feita a massa da onde se fabrica a goma e a carimã, a massa restante vai para a prensa, onde é prensada e levada ao forno para virar farinha.

Forno - o último passo para a fabricação da farinha é levar a massa prensada a um grande forno à lenha, onde ela é torrada e fica pronta para servir de alimento.

Já os personagens envolvidos na farinhada são:

Raspadeiras: papel assumido pelas mulheres, que, usando facas e facões, descascam a mandioca e a repassam para a serragem.

${ }^{56}$ Não consegui saber exatamente qual órgão financiou o projeto. 
Serrador: função desempenhada por um homem que passa a mandioca no caititu.

Espremedeiras: mais uma tarefa atribuída às mulheres, cabe a elas deixar a mandioca de molho, escorrer e espremer a massa da mandioca.

Prenseiro: geralmente, o mesmo homem que trabalha como serrador, depois, assume a função de prensar a massa, que, em seguida, será transformada em farinha.

Forneiro: é também um papel masculino. O homem é encarregado de ficar no forno, espalhando massa prensada, último passo para o feitio da farinha.

A farinhada é um acontecimento que mobiliza toda a comunidade, mesmo os parentes que moram fora, nos períodos de farinhada, intensificam as visitas para participarem dos eventos, que vão muito além da mera fabricação de goma e farinha, constituindo um importante momento de integração e coesão do grupo, permitindo às comunidades reforçarem os vínculos familiares e de vizinhança.

Durante vários dias, homens e mulheres dirigem-se às casas de farinha, onde cada um assume um papel específico. Os papeis são bem divididos, revelando distinções e hierarquias cuja análise merece uma investigação mais detalhada. Evidentemente não me estenderei no assunto por não ser este o escopo da pesquisa ora apresentada.

\section{Atuais alternativas de sobrevivência dos Tremembé}

Definitivamente, o agronegócio do coco é o maior problema enfrentado pelas populações tradicionais do litoral oeste do Ceará, que têm - ou tinham até bem pouco tempo - a agricultura familiar e a pesca artesanal como principal meio de sobrevivência. De acordo com Vasconcelos (2015), o incremento da indústria do coco no Ceará tem se configurado por duas vias: "(1) a monocultura, com o domínio e invasão de terras; e (2) a entrada de agroindústrias de beneficiamento e transformação do coco, em produtos diversos, com destaque às indústrias de alimentação 
e bebidas direcionadas ao comércio nacional e exportação" (p. 123). Muito embora, como destaca a autora, a produção de derivados do coco vai muito além dos produtos alimentícios, mas inclui a indústria de cosméticos e até mesmo a automobilística.

Todos esses fatores têm provocado uma grave crise na atividade agrícola e na pesca artesanal, mas há também outros fatores relacionados a isso. O que descrevi no decorrer deste capítulo foi o contexto no qual o grupo está se inserindo, rapidamente, com todos os efeitos da chamada "sociedade de consumo", na qual atividades como agricultura familiar e pesca artesanal não têm espaço.

Há pouco mais de uma década, o acesso a dinheiro em Almofala era muito restrito. A grande maioria das famílias sobrevivia da agricultura e da pesca, que Ihes garantia a própria subsistência, mas não muito dinheiro. Embora o excedente da agricultura fosse vendido, não sobrava muito além do que as famílias - numerosas que são - necessitavam. Em muitos casos, o excedente era trocado entre os vizinhos. Muitos habitantes da região da Praia iam frequentemente às localidades das Matas para trocar peixe por artigos como feijão, milho e farinha, advindos da agricultura familiar. Os mais velhos contam que produziam praticamente todos os objetos que utilizavam. Desde panelas, feitas de barro, aos talheres de quenga de coco e cabaças até às roupas e redes de dormir, feitas com algodão fiado e tecido pelas mulheres e crianças. Muitas senhoras, como Dona Zeza e Dona Maria Lídia, guardam até hoje seus fusos que exibem orgulhosamente.

Atualmente, ainda que tais atividades sejam essenciais para o grupo e, em quase todas as casas haja agricultores e pescadores, tem-se tornado praticamente impossível manter as famílias somente com produtos advindos destas práticas. Mesmo porque as áreas de roçado são mais escassas e é ponto pacífico entre todos os pescadores que conheci que a produção da pesca também tem caído progressiva e significativamente nos últimos anos. Diante disso, as famílias precisam comprar produtos alimentícios para garantir a própria sobrevivência. Para tanto, recorrem às 
bolsas de assistência instituídas após o Governo Lula, sobretudo ao Programa Bolsa Família que consiste na transferência de renda do Governo Federal, para as famílias de baixa renda e cujas crianças frequentam regularmente as escolas e mantém em dia alguns procedimentos relacionados à saúde, como por exemplo a vacinação. Além do PBF e a aposentadoria dos idosos, as rendas fixas são constituídas pelos empregos nos projetos de saúde e educação diferenciadas. Para as escolas, são contratados, além dos professores, vigias, auxiliares de serviços gerais e secretários. Já a saúde diferenciada conta com os AIS (Agente Indígena de Saúde) e os AISAN (Agente Indígena Sanitarista). Evidentemente, não são todas as famílias que contam com empregos formais que lhes garantem renda fixa, assim, a maioria dos pais e das mães de família sustenta seus filhos com pequenos serviços feitos para terceiros, os chamados "bicos". Muitos agricultores trabalham em terrenos de posseiros, mas raramente são pagos, em geral, nesses casos, o pagamento é feito com uma porcentagem dos produtos plantados. Já os pescadores que trabalham em grandes embarcações geralmente têm renda garantida somente no período de pesca da lagosta, durante o resto do ano, trabalham por conta própria em pequenas embarcações que lhes garantem não muito mais do que o alimento suficiente para suas próprias famílias. Muitas mulheres trabalham como domésticas em casas do centro do distrito de Almofala ou na Sede do Município, mas nenhuma das pessoas que conheci ganha sequer um salário mínimo pelo serviço. São mais raras as mulheres que trabalham fora de casa porque elas acumulam muitas tarefas domésticas com suas próprias casas e filhos. Já os homens, que dificilmente dividem com as mulheres os afazeres domésticos, trabalham mais fora de casa. Muitos deles acumulam vários "bicos". Há muitos agricultores e pescadores que trabalham também como pedreiros na construção civil ou fazem pequenos fretes de moto. Estes últimos são os mototaxistas, que constituem a principal alternativa de transporte não só em Almofala, mas em todas as cidades do interior do Ceará, já que não há transporte público que atenda as comunidades. Alguns mototaxistas com quem conversei me afirmaram que conseguiram pagar a 
prestação da moto com o dinheiro de programas sociais além de, claro, a própria renda gerada pelo trabalho com a moto. Os acidentes também se multiplicam, pois praticamente nunca usam equipamentos básicos de segurança, como capacete. Quase semanalmente há graves acidentes de moto em Almofala, muitos deles fatais, principalmente nos finais de semana, depois das festas, quando muitos motoqueiros - mototaxistas ou não - dirigem após consumir bebida alcoólica.

Ou seja, o que vemos é que com a perda do acesso à terra, os Tremembé precisam recorrer a outros meios de existência. Para ter acesso ao básico para a sobrevivência das famílias - comida - eles precisam de dinheiro. Isso pode parecer óbvio, mas há algumas décadas - ainda que enfrentassem muitas dificuldades - o acesso à terra possibilitava não só o cultivo de roças como a colheita de frutas nativas que cresciam em meio à mata. Muitos dos depoimentos coletados em campo falavam de um tempo onde, ainda que a estiagem levasse à perda das plantações, havia a opção das chamadas frutas do mato às quais os Tremembé recorriam em tempos de seca prolongada. Além disso, a pesca era bem mais farta.

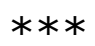

Na região amazônica, muitos trabalhos tanto no âmbito da antropologia, como da arqueologia abordam a forma pela qual as populações indígenas interagem com diferentes ambientes na floresta. No Nordeste do Brasil, entretanto, cristalizou-se a imagem de um ambiente inóspito. A seca da caatinga, bem como a vastidão dos desertos de areia litorâneos sempre foram tratados como ambientes desfavoráveis à sobrevivência humana, de onde seus moradores, nos períodos de estiagem, precisam se deslocar para as áreas urbanas do país em busca de melhores condições de vida. Porém, nos dados etnográficos colhidos em campo, não é esta ideia que prepondera, ao contrário, os ambientes são descrito como fartos, - embora haja muitos relatos sobre os períodos de seca, no qual enfrentam muitas dificuldades, diante dessas dificuldades eles apresentam 
também alternativas de manejo que Ihes garante a sobrevivência. Aqui vale destacar, que as áreas litorâneas sofrem menos com a estiagem do que as áreas de caatinga, no interior do estado, pois, nas áreas perto do mar, o lençol freático é mais farto, desta forma, os poços dificilmente secam. Muito embora, seja necessário afirmar aqui que a seca, bem como as migrações são uma realidade que atormenta a vida dos moradores, tanto do litoral como da caatinga, o que quero evidenciar são as alternativas que os Tremembé me mostraram para todas estas adversidades. Por isso optei por fazer uma breve explanação sobre a agricultura neste capítulo, pois o conhecimento sobre as plantações, o tipo de clima, de solo, de água nos mostram que essas práticas se fazem nas relações com os encantados, como espero ter deixado claro no capítulo anterior.

Muitos interlocutores - especialmente os mais velhos - me advertiram que, desde a chegada da energia elétrica, os encantados se fazem mais raros. Eles gostam de escuridão, onde podem se esconder na noite e apreciar o silêncio, por isso, ficam demasiadamente incomodados com os postes de iluminação e os barulhos dos eletrodomésticos, especialmente, televisões e aparelhos de som.

Durante os dias da semana, o silêncio impera pelas praias de Almofala, ainda que haja algum movimento de carro e moto, o que mais se escuta nas andanças pelos caminhos - até mesmo as estradas - é o som do vento que bate nas palhas dos coqueirais. Nos finais de semana o cenário é outro. Pois, desde que foi aberta a estrada que liga Almofala à principal rodovia do litoral Oeste do Estado, as pessoas das redondezas procuram as praias de Almofala, ocasionando muito barulho provocados por carros e "Paredões", como são chamadas as enormes caixas de som que são acopladas aos carros e fazem ecoar forrós e funks a metros de distância. Nessas ocasiões, muitas pessoas, índios e não índios, festejam, dançam, comem e bebem na beira do mar. Como o serviço de coleta de lixo é precário na região, estas festas deixam um lastro de sujeira que diariamente é engolida pela enchente da maré. Mas isso não ocorre somente nas Praias de Almofala, as lagoas também recebem muitos turistas 
nos finais de semana, entre moradores das redondezas e esportistas, especialmente praticantes de Kite surf. Assim, esportistas e outros visitantes deixam seus carros na beira das lagoas e se põem a "aproveitar" as areias e águas, à revelia dos encantes que nelas habitam. Isso irrita os encantados, como me explicaram muitos pescadores que frequentam as lagoas. Ao mesmo tempo em que os encantados também têm estratégias para permanecer naqueles lugares - como as Mães d'Água que moram no fundo das lagoas e, quando lhes é conveniente, evitam as superfícies muitos depoimentos afirmam que os encantes se afastam dali, pois não gostam do barulho dos carros, das caixas de som e do movimento intenso que toma conta do lugar.

As imagens veiculadas nas propagandas turísticas sobre as praias do Nordeste as descrevem como praias "desertas", lugares inabitados, onde se é possível ficar em contato com a "natureza" e longe do caos das grandes cidades. Obviamente, a indústria do turismo não leva em conta a presença dos humanos que habitam as regiões litorâneas, muito menos dos não humanos, os quais, quando muito, são retratados como "lendas", "folclore" e elementos pitorescos da "cultura brasileira". É comum nos programas esportivos televisionados no Brasil a prática de esportes em praias "desertas" que são palco de práticas esportivas como corridas de Jeep ou motos. Por duas vezes presenciei, na localidade da Passagem Rasa, a invasão de dezenas de motos que passavam em alta velocidade por entre as casas da comunidade, provocando sério risco para as crianças que brincavam desatentas nos terreiros das casas e correram riscos de atropelamento, por sorte, em nenhum dos casos houve vítimas humanas, mas alguns animais, como cachorros e porcos, foram atropelados, para prejuízo e tristeza de seus donos. O fato levou as lideranças da localidade a fazer uma denúncia formal à FUNAI, que se comprometeu em tomar as providências cabíveis em relação aos organizadores do evento esportivo.

Em uma conversa que já expus aqui, no capítulo anterior, com o pajé Luís Caboclo, ele dizia que quando vai fazer seus rituais na mata, se ouvir qualquer voz humana, ele permaneceria no outro mundo. A voz 
humana romperia o elo e o deixaria, eternamente, num estado de encantamento. Daí a dificuldade de se praticar tais encontros, pois não há mais lugar que atenda essa necessidade de isolamento.

Evidentemente não é objetivo desta pesquisa analisar o fracasso das políticas desenvolvimentistas e seus efeitos em comunidades indígenas e tradicionais, mas era indispensável relatar as transformações nos modos de vida dos Tremembé. E é impossível, atualmente, descrevê-los, como as etnografias escritas há poucas décadas o faziam ${ }^{57}$, como um grupo que vive apenas - ou principalmente - de atividades "tradicionais" como a pesca artesanal e a agricultura familiar.

Hoje, muitos objetos "modernos" compõem o cotidiano dos Tremembé. Aparelhos de telefone celular, computadores e GPS fazem parte desse cotidiano e, eles também, trazem consigo novas realidades. Alguns pescadores, por exemplo, contam com o auxílio de aparelhos de GPS para se orientar em alto mar, coisa que, antes de ter acesso ao aparelho, faziam através da direção do vento, da localização das estrelas e de outros elementos. Inclusive, quando cheguei em campo, munida de um aparelho de GPS que eu mesma não fazia a menor ideia de como usar, quem me deu toas as orientações foi um pescador que havia comprado um aparelho para usar nas suas pescarias. As crianças, especialmente, mostram uma profunda facilidade de compreender o funcionamento de alguns aparelhos que eu - que tenho uma particular dificuldade com aparelhos eletrônicos tenho uma profunda dificuldade. Pouco antes de ir a campo, eu comprei uma máquina fotográfica digital que, nas horas vagas da pesquisa, fazia a alegria das crianças que passavam o tempo a fotografar umas às outras e, assim, iam descobrindo novas funções e efeitos que eu desconhecia por completo. Confesso que aprendi muito mais com elas do que com o complicado manual de uso que elas, todavia, não precisaram ler para descobrir os "segredos" do aparelho.

\footnotetext{
57 Não que tais etnografias não tivessem sido capazes de descrevê-los bem, mas porque a situação atual é bem diferente do que era a pouco mais de uma década.
} 


\section{Os encantados e as novas tecnologias}

Se faço aqui uma breve descrição dos "novos" objetos que compõem o atual cotidiano dos Tremembé, não é com o intento de, simplesmente, fazer alguma comparação entre os "novos" modos de viver das atuais gerações em relação às mais antigas, pois entendo que tão somente contrapor o "novo" e o "velho", não sairia do óbvio. O que pretendo é levantar questões - ainda que não possa responder a todas elas - sobre as relações que vêm sendo estabelecidas entre humanos e encantados frente a essas formas de viver. Qual o lugar dos encantados nesse mundo pleno de eletricidade, internet, e tantos novos elementos que também trazem consigo novas ontologias?

As descrições apresentadas no presente capítulo, sobre as transformações decorrentes da inserção dos Tremembé na sociedade de consumo, são imprescindíveis para que possamos considerar as formas de relação e de acesso aos mundos dos encantes no atual contexto de transformações. Se, conforme aponta Ingold (2000), habitar e conhecer são ações indissociáveis, os modos de habitar a Almofala dos Tremembé - com suas matas, seus mares, suas dunas e manguezais - nos revelam suas formas de conhecer e de se situar nos ambientes em que circulam. Ambientes hoje atravessados por carros, motos, eletrodomésticos, bancos, cartão de crédito e crediário nas lojas. Como esses elementos tão diferentes interagem entre si?

O que posso depreender da experiências e vivências com os Tremembé remete à sua capacidade de se situar em múltiplos domínios, entre os quais há caminhos a percorrer. Assim, eles indicam que os mundos encantados ora se mostram incompatíveis com modos de viver dominados pelas novas tecnologias, ora - ao contrário - computadores e celulares chegam a registrar a presença dos encantados.

$\mathrm{Na}$ minha primeira viagem a campo, no início da pesquisa de doutorado, em visita à Escola da Praia, presenciei um burburinho que juntou várias crianças e adolescentes que se punham em fila na porta do 
laboratório de informática para ver um vídeo que estava sendo veiculado na internet que mostrava um ser de outro mundo que havia sido capturado na praia de uma cidade vizinha. As imagens mostravam uma mulher cobra - um ser que tinha cabeça de mulher e corpo de cobra - e foi o assunto mais comentado pelas crianças e adolescentes da escola durante a semana que fora veiculado. As discussões giravam em torno da veracidade do vídeo. A maioria dos adultos - os que tiveram coragem para ver as imagens, já que muitas pessoas ficaram com medo de vê-la - dizia que não era uma imagem real, pois se tratava de uma cabeça de boneca que havia sido acoplada em um corpo de cobra, ademais, não poderia ser real porque os encantes jamais deixam-se ver, nem mesmo por câmeras fotográficas. Já as crianças que viram o vídeo ressaltavam que os aparelhos eletrônicos possibilitavam o registro de seres que nunca haviam sido vistos antes, pois, agora que muitas pessoas andam munidas de câmeras fotográficas e de vídeo, nada poderia escapar das lentes, que poderiam "provar" a existência de seres de outros mundos. Certa vez, enquanto conversava com Dona Neném Beata na varanda de sua casa, situada em cima de um morro, ela me mostrava o cenário onde ela avistava o fogo fato - o fogo que sinaliza a existência de uma butija no lugar. Ela me dizia que via muitas luzes ali quando caía a noite, mas nunca havia tido coragem de procurar os tesouros encantados. Nos últimos tempos, entretanto, continuava a ver luzes e fogos, mas não sabia mais se se tratavam de encantes ou aparelhos de celular, usados pelos transeuntes para iluminar seus caminhos.

Embora a maioria das pessoas asseverem a incompatibilidade da coexistência de encantes e novas tecnologias - pois as entidades ficam incomodadas com barulhos e postes de iluminação -, muitos atestam que, mesmo em áreas cercadas pela Ducoco, vivem ancestrais que erguem aldeias encantadas e continuam a viver ali, da mesma forma como viviam antes de se encantarem.

Entretanto, a grande maioria das pessoas assegura a incompatibilidade de existência entre o sistema de encante e agronegócio. Pois, como venho demonstrando a partir dos dados coletados em campo, 
os encantes estão, intrinsecamente ligados à natureza, sem ela, os lugares deixam de ser encantados, perdem a capacidade de encantamento. Se as matas, dunas, mangues e águas estão sob ameaça, os encantes que circulam por tais lugares também correm o risco de desaparecer junto com eles. Na conversa abaixo, Delly, a mais jovem pajé de Almofala, me dizia que, como ela pode ver entidades encantadas, tem podido observar que as aparições estão mais raras, porque os encantados estão "diminuindo".

\footnotetext{
Delly: Tão diminuindo... as histórias tão diminuindo... porque os locais que eles gostam de ficar... porque antigamente tinha muita árvore, muito mato, muitas lagoas... e o ser humano vem fazendo com que isso se modifique, né? Bastante! Nessas regiões por aqui por perto, tem muito pouco... muita pouca mata! As lagoas tudo secando... e, assim, as histórias vão morrendo, porque o povo vão vendo tudo mudando... Depois dessas eólicas! É uma destruição tão grande! Aí tudo que tem nesses lugares vão caçando outros locais. Juliana: e tu acha que eles vão pra onde?

Delly: Aí eu não sei, porque às vezes eles vão pra cantos inusitados! Ficam perturbando as pessoas porque não tem canto mais pra eles ficarem.
}

A ideia de que, com o desmatamento, os encantados estão a abandonar as paisagens de Almofala já foi exposta aqui inúmeras vezes. As respostas sobre quais alternativas eles encontram após essa "fuga" são as mais variadas. No caso exposto acima, é importante observar que Delly aponta para o risco de eles se põem a perturbar as pessoas já que não têm mais natureza onde possam viver tranquilamente. Em outras ocasiões, essa possibilidade também me foi apontada como sendo uma retaliação dos encantados que, tendo suas moradas destruídas pelos humanos, se ocupariam em atrapalhar suas vidas como forma de castigá-los pelos estragos que vinham fazendo na natureza.

Espero ter elucidado com as descrições expostas neste capítulo, as formas como os Tremembé e os encantados estão lidando com as transformações no território e no cotidiano que compartilham. As descrições 
sobre o atual cenário dos Tremembé de Almofala expõem várias contradições decorrentes tanto de uma dinâmica interna do grupo - como a intensificação do consumo entre seus membros e o crescente processo de urbanização que vem se desenrolando na região - como de uma imposição arbitrária de segmentos outros, como as indústrias de energia solar, de pesca e do agronegócio, além de, claro, o próprio Estado, que, ao mesmo tempo em que apoia amplamente tais empreendimentos com incentivos fiscais e outras facilidades ${ }^{58}$, mostra-se alheio e incapaz de efetivar os direitos dos povos indígenas às terras que tradicionalmente ocupam.

Para compreender às relações estabelecidas entre humanos e encantados em Almofala, não podemos perder de vista elementos que, aparentemente, em nada se relacionam entre si. Mães d'Água, fogo-fato e butijas coabitam com aparelhos de celular, computadores e carros de som. Procurei expor aqui as formas como essas diferentes ontologias estão se pondo em contato.

$\mathrm{Na}$ última parte deste capítulo, ao descrever o cotidiano das famílias com quem convivi em Almofala, pretendo esmiuçar as relações entre humanos e encantes nos atuais contextos vividos pelos Tremembé e, assim, aprofundar algumas das questões levantadas aqui.

58 Uma descrição mais detalhada do apoio do Estado ao agronegócio do coco, por exemplo, pode ser vista em Vasconcelos (2015). 


\section{Parte 2}

Procurarei expor, nesta última parte do texto, as formas como os lugares apontados como moradas dos encantados são caracterizados e vivenciados pelos Tremembé. Para isso, será preciso atentar para as atividades do cotidiano do grupo, para a forma pela qual os habitantes de Almofala transitam pelos lugares, tecem seus caminhos não só pelas matas, dunas e manguezais, como pelos quintais das casas, pelos cercados uns dos outros... Para organizar uma narrativa em torno dessas experiências, escolhi alguns interlocutores, entre os que me apresentaram os encantados nas trilhas percorridas cotidianamente.

\section{As formas de habitar a Almofala dos Tremembé}

Se, na primeira parte deste capítulo, descrevi as características espaciais do território Tremembé, aqui, se tratará do desenrolar da vida nesses lugares, a partir da minha própria inserção no cotidiano das famílias que me permitiram acessar seus movimentos pelas moradas dos encantados.

A intenção inicial da pesquisa era realizar um mapeamento dessas moradas e discutir como elas são geridas pelos mais diversos atores que as ocupam. Assim, após a qualificação, decidi voltar a campo pronta para mapear essas moradas, anseio fomentado inclusive pelos acontecimentos que se desenrolavam quando da minha chegada. A comunidade estava às voltas com a instalação de dois parques de energia eólica nas proximidades da área indígena. Havia um antropólogo trabalhando na preparação do Estudo do Componente Indígena para o processo de licenciamento ambiental e, nas conversas que tivemos com ele e algumas lideranças que acompanhavam esse processo mais de perto, foi levantada a necessidade de se incluir no estudo a obrigatoriedade de preservação das áreas habitadas pelos encantados, sendo preciso, então, mapeá-las. Ao 
acompanhar parte do trabalho da equipe de licenciamento ambiental, procurei entender, inclusive visitando outras comunidades não indígenas, as consequências dessas obras para os habitantes de Almofala. A essa altura, eu ainda insistia na ideia de fazer um mapeamento das moradas dos encantados. Porém, não é novidade no exercício antropológico que a dinâmica da experiência de campo nos coloca, por diversas vezes, diante de surpresas e impasses. E foi o que aconteceu. Quando comecei a debater tal questão com as lideranças que se dispunham a me ajudar no trabalho de mapeamento, elas mesmas ficavam confusas nos procedimentos a adotar, pois todo lugar em Almofala pode ser morada de alguma entidade encantada, desde que contenha elementos da natureza, como árvores, pedras, águas, matas etc.

Na prática, portanto, ninguém - nem eu e nem as lideranças sabia por onde começar tal mapeamento, pois quaisquer árvores, águas, dunas entre vários outros elementos podem ser escolhido como morada para algumas entidades. Além disso, como destaquei no segundo capítulo, para além das ações de seres encantados - como o Caipora, o Guajara, as Mães d'Água e os Caboclos da Umbanda, elementos da natureza portam, em si mesmos, um encante. O fato é que isso pulverizava meu "leque de lugares a serem mapeados" de uma forma que tornava impossível a realização de um mapa, ou mesmo de vários mapas, que pudessem contemplar tais manifestações. Em quase todas as casas que eu visitava, os habitantes apontavam algum lugar, nos quintais de casa ou nas redondezas nos quais haviam percebido manifestações encantadas.

O que fazer diante desta constatação? Seria possível realizar tal mapeamento sem correr o risco de reduzir a dinâmica desses lugares a um registro de pontos que, por definição, permaneceria sempre estático? O fato é que, na prática cotidiana, essas moradas são muito mais dinâmicas do que eu poderia imaginar. Se a crescente urbanização e a "falta de espaço" na área afetam os humanos e os levam a construir moradas "fixas"- como os cercados e as casas de alvenaria -, as moradas dos encantados, embora também sejam afetadas de várias maneiras, continuam dinâmicas, pois as 
entidades transitam por vários lugares - aliás, não só por lugares, mas por mundos - com muita facilidade. Frente à intensidade desses movimentos, entendi, então, que eu estaria recorrendo a um reducionismo se "fixasse" essas moradas em mapas.

Diante desse impasse, resolvi que, ao invés de tentar mapear tais áreas, eu deveria focar na forma como as mais diversas entidades Tremembé e encantados - circulavam por alguns lugares de Almofala. Deste modo, proponho focar nos modos como estes lugares são caracterizados através da vivência de seus habitantes. Para tanto, preciso tirar o foco do lugar em si e me centrar nas formas de habitar esse lugar. Para isso, penso que já contribuíram as descrições feitas na primeira parte deste capítulo sobre as atuais configurações espaciais em Almofala, importantes para entendermos o atual contexto. Em outras palavras, o que pretendo é focar nos modos como os Tremembé definem os potenciais de vida nos lugares. Como sugere Ingold (2015), os antropólogos devem trazer 'a vida' para o centro de suas investigações. Algo que foi deixado de lado pela antropologia, que quando muito concebe a vida como um movimento finalístico ou teleonômico, moldado por padrões culturais. Sua proposta consiste num movimento oposto: perceber a vida como um processo em constante movimento, um movimento caleidoscópico, cujas possibilidades são inesgotáveis. Assim, dando continuidade às reflexões propostas em The Perception of the environment (2000) - nas quais ele se opõe a uma antropologia centrada na análise do comportamento humano através de padrões culturais - Ingold recomenda que a Antropologia seja uma "investigação constante e disciplinada das condições e potenciais da vida humana" (2015, p.25). Para ele,

É da essência da vida que ela não comece aqui ou termine ali, ou conecte um ponto de origem a uma destinação final, mas sim que ela continue, encontrando um caminho através de uma miríade de coisas que formam, persistem e interrompem seu percurso. A vida, em suma, é um movimento de abertura, não de encerramento. Como tal, deve estar no próprio cerne da preocupação antropológica. (p. 26) 
A vida, conclui o autor, é vivida não em lugares, nem dentro de lugares, mas através deles. A ideia de um mundo dividido em partes ocupadas - cada uma delas - por um povo ou nação; um mundo passível de ser cartografado, medido e dividido racionalmente é uma ilusão cartográfica ocidental. A vida é essencialmente movimento e, portanto, se efetiva através de um longo e contínuo processo de peregrinação, uma experiência corporificada do movimento de perambulação (idem: 219). As reflexões apresentadas neste capítulo iluminarão as questões relativas ao movimento de perambulação de humanos e dos encantados pelas paisagens de Almofala. Descreverei minhas experiências de peregrinação através das casas das famílias que se dispuseram a me hospedar.

Para compreender, portanto, os modos de caracterização dos lugares encantados em Almofala, é preciso atentar para as perambulações empreendidas cotidianamente pelos Tremembé. Dedicar-me-ei aqui aos movimentos que tive a oportunidade de acompanhar pelos lugares mais suscetíveis à aparição de encantados.

\section{Donos ou moradores}

Os dados apresentados nesta tese revelam que os Tremembé circulavam pelas terras de Almofala sem estarem preocupados em permanecer confinados em determinada área. A necessidade da demarcação de um território surge a partir de uma situação pós-colonial de esbulho, massacre e usurpação das áreas tradicionalmente ocupadas. Mas, nos tempos em que as terras eram no aberto, frequentemente as famílias de agricultores e pescadores transitavam entre a praia e as matas. Algumas pessoas contam que, nos tempos do inverno, desmanchavam suas casinhas de palha na praia e as reerguiam nas matas, perto de lugares de solo mais fértil, onde poderiam plantar suas roças. Já no período de estiagem, voltavam para as áreas mais próximas ao mar. Atualmente, diante do avanço da especulação imobiliária na região, tal situação é inimaginável, pois, frente à reorganização territorial vivenciada pelos Tremembé, eles se veem obrigados a delimitarem seus terrenos e cercá-los, como garantia de 
passá-los como herança aos seus filhos. As dinâmicas em relação às moradias foram profundamente afetadas, como já demonstrei neste capítulo. Mas e os encantados, como são afetados por essas mudanças? Mais do que isso, como reagem a elas?

Como vimos no segundo capítulo, algo em comum entre as mais diversas narrativas sobre os encantados é que eles habitam as paisagens classificadas pelos Tremembé como naturais, sendo apontados, não raro, como donos desses lugares. Todavia, embora escolham algumas áreas como morada, os encantados não necessariamente se mantem nelas, ao contrário, eles transitam por diferentes mundos. Quando eles elegem um determinado lugar para morar, passam a protege-lo a guarda-lo, contudo, no caso de sentirem-se incomodados, nada os impede de sair dali e procurar outros lugares. Já que, como argumentam meus interlocutores, há ainda muitos lugares, mesmo no Brasil, ainda plenos de natureza onde eles possam viver.

A assertiva de que os encantados estão a abandonar a Almofala dos Tremembé em busca de outras áreas foi apontada em muitos dos relatos coletados em campo. Estão se evadindo na medida em que a devastação ambiental avança nas terras e águas. Confesso que fiquei muito inquieta quando comecei a ouvir isso repetidas vezes. Perguntava-me como - se os encantados eram apontados como donos dos lugares, que os guardavam, protegiam e tinha, inclusive, o poder de castigar muitos dos que tinham uma má conduta em relação às suas moradas -, eles poderiam abandonar os lugares que sempre habitaram e mudarem-se para outros lugares com tanta facilidade e desprendimento? Ao refletir sobre a questão, procurando contextualizá-la com os recentes acontecimentos em Almofala, percebi que a noção de dono não revela, necessariamente, uma posse, mas é algo circunstancial. A necessidade de manter uma propriedade através de gerações é uma necessidade humana, criada a partir de um processo de espoliação das terras ocupadas pelo grupo. Os encantados só se mantém em determinada área se houver condições de existência para eles, condições dadas pela presença de elementos naturais, assim, caso a 
natureza pereça e deixe de existir em algum lugar, esse lugar perderá sua capacidade de encantamento, pois o encante é a própria natureza.

A noção de dono está presente em inúmeros estudos de cosmologias amazônicas. Gallois (1988), observa que, na cosmologia Wajãpi, todas as coisas existentes no universo têm um dono (-jarã), cuja atribuição é garantir a sua reprodução, manutenção e desenvolvimento das suas criaturas. As relações dos donos com os humanos se efetivam através das retaliações lançadas àqueles que, de alguma forma, interferem nos domínios, provocando algum desequilíbrio. Nessas ocasiões, os donos podem provocar fenômenos das florestas, como ventos fortes ou queda de árvores, como manifestação da sua fúria. Mas esses donos também são auxiliares dos xamãs a quem transferem capacidades de cura.

Entre os Tremembé, a noção de que os encantados, enquanto donos dos lugares e elementos da natureza, protegem suas moradas e, para afastar invasores, provocam fenômenos e sensações corporais também é bastante recorrente. Na lida cotidiana com as paisagens escolhidas como moradas de encantados, observamos que estas entidades travam uma disputa com os humanos pela manutenção da tranquilidade e do equilíbrio não só dos lugares que protegem, como dos recursos deles provenientes.

As retaliações por alguma má conduta em relação aos lugares podem ser as mais variadas, mas, como alguns relatos expostos no decorrer da tese já demonstraram, costumam se manifestar através de doenças lançadas àqueles que desrespeitam as moradas ou os encantados, simplesmente, provocam sons ou ventanias para assustar os humanos e afastá-los de suas moradas. Entretanto, mesmo aqueles humanos que nunca tenham tido conduta alguma de desrespeito com lugares ou entidades encantadas podem, também, sofrer com as ações dos encantados. Quando eles agem no sentido de afastar os humanos, portanto, nem sempre se trata de uma retaliação, mas, muitas vezes, de manter uma separação necessária entre mundos visíveis e invisíveis. 
As fronteiras entre os mundos dos vivos e dos mortos são, pois, necessárias e atravessar esses mundos é algo extremamente perigoso, tarefa empreendida somente pelas pessoas escolhidas, as que têm o dom e podem, se assim o quiserem, tornarem-se pajés. As pessoas que não têm experiência ou sabedoria para perceber a presença de encantes correm sérios riscos ao circular pelas suas moradas. Aprendi com os Tremembé que ninguém está imune às ações dos encantados. Diversas vezes, enquanto estava nas casas de rezadeiras, como Dona Maria Bela e Dona Neném Beata, observei que, quando alguém chegava às suas casas em busca de rezas para curar enfermidades, elas perguntavam, antes de qualquer atitude, por onde a pessoa havia andado, o que tinha feito nos dias anteriores, e, muitas vezes concluíam que se tratava de uma pisa de alguma entidade moradora das matas - encantados - ou espíritos, que haviam se encostado neles.

A questão que levanto em relação a este dado é: quais são, enfim, as atribuições dos donos ou moradores das matas de Almofala em relação aos lugares que habitam? Muitos depoimentos revelam que eles são donos - assim como aparecem nas etnografias sobre a Amazônia Indígena - não só os lugares, mas tudo o que nele existe: animais, plantas, pedras... Várias histórias me foram contadas sobre isso. Um professor da Escola Indígena da Tapera, Eudes, conta sempre um caso acontecido com seus parentes pescadores por ocasião de uma pescaria na Lagoa da Batedeira. Os pescadores lançaram a rede e, ao percebê-la plena de peixes, começaram a arrastá-la para fora. Quando conseguiram emergi-la, perceberam, com surpresa, que a rede vinha vazia. Alguém havia cortado a rede e a remendado com imbira - um cordão feito de tabuba, planta que abunda nas Lagoas de Almofala. Eudes destaca alguns elementos desse episódio: primeiro, o fato de que, em muito pouco tempo, a rede havia sido cortada e remendada, o que sugere que o fato tenha ocorrido em outro plano de existência temporal, em outras palavras, um plano onde o tempo passa de outra forma; segundo, ele observa a preocupação que teve o encantado ao remendar a rede com um cordão feito de uma planta nascida na própria 
lagoa. Segundo ele, o ato de remendar a rede teve o intuito de não deixar dúvidas sobre quem havia libertado os peixes. Somente um encantado poderia alterar o tempo deste modo. Não restavam dúvidas, portanto, que Mãe d'Água, moradora das águas profundas da lagoa, estava dando-Ihes um sinal de que não queria perturbação da sua morada naquele momento, por isso não queria pesca na sua morada naquele dia.

Durante os dias que passei na comunidade, recebi, por um final de semana, um casal de amigos que fazem pesquisa sobre a vegetação nativa da região e estavam ávidos para conhecer Seu Zé e fazer com ele algumas incursões nas matas da Passagem Rasa. No segundo dia de visita, depois de andarmos bastante pelas matas no dia anterior, meu amigo resolveu ir sozinho, logo depois do café da manhã, dar um passeio pelas matas. Ele julgava já ter conhecimento suficiente dos caminhos pelos quais andamos e tranquilizou-nos quanto a isso. Ninguém se dispôs a acompanhá-lo, mesmo porque, ele disse não pretender ir muito longe, queria apenas voltar a um determinado local para registrar algumas imagens que havia deixado passar durante a caminhada com Seu Zé. Entretanto, o tempo passou e ele demorou a voltar. Fomos a algumas casas da vizinhança à sua procura, mas nada de encontrarmos. Logo, Manuel se propôs a procurá-lo pôs-se a seguir o rastro que ele havia deixado pela areia. Em nossas caminhadas, eu já havia percebido a habilidade que tanto Manuel como Seu Zé tinham de rastrear pessoas e animais pelos areais do lugar. Ao longo da caminhada em sua busca, Manuel conseguia identificar, inclusive, os momentos em que ele andava de chinelos ou com os pés descalços pelas pegadas que ele havia deixado na areia, assim, não foi difícil encontrá-lo, embora tenhamos andado bastante à sua procura. Quando finalmente o encontramos, todos no lugar passaram a gozá-lo, pois constataram que ele havia sido trapaceado por Caipora, que propositadamente, fez com que ele se desorientasse em meio ao matagal.

Logo, a história do rapaz que se ariou nos matos se espalhou pela vizinhança e, em todas as casas onde passávamos, as pessoas comentavam e contavam histórias semelhantes que haviam acontecido com elas mesmas 
ou algum conhecido. Diziam que Caipora, para zombar das pessoas e para "mostrar quem manda" nos matos, costuma deixar mesmo os moradores mais antigos e experientes ariados de vez em quando.

Notemos nenhum desses casos se trata de um castigo, nenhum dos atores envolvidos nos episódios havia tido qualquer conduta desrespeitosa com o lugar, ainda assim, a presença deles incomodava59. A própria presença de humanos incomoda. É preciso, portanto, que os humanos façam o esforço de convencer o encantado, dono do lugar, de serem aceitos e poderem adentrar suas moradas. Essa negociação pode ser feita de diferentes formas, como disse no segundo capítulo, uma delas é ofertando fumo ao dono, como já vimos.

Mais uma vez, ao repassar minhas questões aos Tremembé, ouvi diferentes versões sobre os encantados e suas atribuições enquanto donos ou moradores. Uns me diziam que eles garantiam os recursos provenientes dos lugares como dunas, lagoas, matas e mangues. Já outros afirmavam seguramente que os encantamentos estavam em vias de desaparecer para dar lugar a postes de iluminação, carros e estradas. Isto porque, os humanos não têm mais respeito por suas moradas. A questão do respeito é algo sempre recorrente nas narrativas. Se os encantados não estavam sendo respeitados nas suas moradas, não havia como permanecerem nelas, preferiam para lugares mais ermos, longe dos humanos, na natureza.

Um bom exemplo para ilustrar esses conflitos ontológicos é o caso da Lagoa Verde, que nunca havia secado por servir de morada a uma Mãe d'Água que garantia um espelho d'água, ainda que pequeno em períodos de estiagem severa, nunca desaparecia totalmente. A Lagoa fica na localidade da Camboa, na região da Praia de Almofala. Até a pesquisa de campo do doutorado, eu só havia feito uma visita rápida à comunidade e não conhecia bem seus moradores. Foi Dona Maria Lídia, moradora do Panã, de quem já falei neste trabalho, que me levou para conhecer a lagoa.

59 Notemos que, na maioria das narrativas, os objetos utilizados pelos encantados são feitos manualmente com matéria-prima encontrada nas matas ou águas, como conchas e quengas de coco. 
Dona Maria Lídia tem uma aptidão especial para se lançar a longas caminhadas e essa, entre outras qualidades, a tornou uma interlocutora fundamental para esta pesquisa. Conheci várias das localidades da Praia a acompanhando em suas viagens entre o Panã e os Torrões, situadas a $5 \mathrm{~km}$ de distância uma da outra. Ela mora no Panã, mas construiu também uma pequena casa nos Torrões, onde atualmente mora uma filha. Tendo ficado viúva cedo, Dona Maria Lídia começou a trabalhar vendendo comida de porta em porta. Ela conta que, quando começou com esse trabalho, vendia somente os bolos que fazia em casa, mas hoje ela vende também outros produtos, como balas e salgadinhos industrializados de milho. Ainda hoje, apesar da idade avançada - ela é nascida em 1940 - ela caminha léguas por dia, carregando pacotes bem pesados plenos de vendendo doces e outros pequenos objetos artesanais, como toalhas bordadas e tapetes de retalhos. Por mais disposição que tenha o peregrino, algumas caminhadas são deveras cansativas, sobretudo sob o efeito do sol forte e do peso a carregar. Talvez por isso Dona Maria aceitava sempre de tão bom grado minha companhia para suas peregrinações. Nas minhas últimas visitas à área, entretanto, caminhamos bem pouco, praticamente só entre as comunidades vizinhas ao Panã, como a Praia de Almofala, o Barro Vermelho e a Camboa. Quando ela me convidava a um destino mais distante, como sua casa nos Torrões, sempre chamava algum vizinho que trabalhava como mototaxista para ir nos deixar. Ainda assim, vez por outra ela precisava se deslocar caminhando, pois, pelas atividades que desenvolve, às vezes precisa fazer cobranças de casa em casa e, por isso, ela vai mesmo a pé, seguindo as trilhas pelas matas e dunas até os Torrões. Como Dona Maria conhece bem a região, nunca nos deslocávamos pelas estradas, somente pelas matas, atravessando muitas cercas de arame pelo caminho entrecortado por elas. A cada cerca, ela me alertava sobre a necessidade de benzer-me, pois, se encantados habitam a natureza, as cercas abrigavam espíritos malfazejos, que ficavam sempre ali, à espera de alguém em quem pudessem se encostar. 
A Lagoa Verde é chamada assim por abrigar uma mata de tabuba ${ }^{60}$, por isso, está sempre verde, tingida pelo grande tapete de capim que alcança toda sua extensão. Em vários depoimentos colhidos em campo, diz-se que a Lagoa Verde jamais secou, pois é lá que Mãe d'Água usa a água para seus afazeres domésticos. Eu nunca colhi em campo um depoimento em que uma pessoa afirmasse ter visto, ela mesma, Mãe d'Água, Caipora ou Guajara, mas todos afirmam que pessoas bem próximas já lhes haviam visto. Dona Maria Lídia conta que seu pai, nesta mesma lagoa, avistou, certa vez uma moça de pele clara e longos cabelos que se banhava, derramando água sobre si mesma com uma concha de ouro. Ao avistá-lo, a moça, assustada, mergulhou na lagoa e sumiu, deixando cair a concha. Seu pai, sem pensar duas vezes, foi pegá-la para levá-la consigo como prova do que havia presenciado, todavia, antes de conseguir tocá-la, a pequena concha desapareceu. Quando ele, ao chegar em casa, contou o acontecido para familiares, informaram-no de que ele havia tido muita sorte de a concha ter sumido antes do seu toque, pois, caso estivesse tocado no objeto encantado, ele também encantar-se-ia, passando para um modo de existência no qual não poderia ser visto pela maioria das pessoas, inclusive seus familiares.

Essa é só mais uma das diversas narrativas colhidas onde se contam encontros com Mãe d'Água, que mora na Lagoa Verde. Confesso que, depois de tantos depoimentos, quando decidi frequentar mais assiduamente esses lugares, esperava deparar-me mais com certas prescrições em relação aos encantados que eram tão mencionada nos relatos sobre encantes. Muitas pessoas que trabalhavam no mangue ou nas lagoas, por exemplo, falavam que era necessário presentear os encantados que lá moravam para que tivessem sucesso nas suas atividades. Entretanto, o que percebi foi que as referências a eles fogem do cotidiano. Dão-se em situações que fogem do trivial, como quando alguém se perde nas matas

${ }^{60}$ A tabuba (Typha domingensis) é uma espécie muito comum em espelhos d'água e, na região, é utilizada na confecção de esteiras e pequenas balsas para pesca nas lagoas. 
ou quando têm alguns sintomas corporais e atribui estes sintomas a ação de encantados.

Na Lagoa Verde, mesmo nos anos de seca, há um buraco bem no meio da lagoa que jamais havia secado. É o buraco da Mãe d'Água, onde ela se banha e, por isso nunca havia deixado faltar água. Nos últimos anos, entretanto, a estiagem tem sido mais severa, não só ocasionada pela falta de chuva, mas pelo incremento do agronegócio do coco que necessita de muita água para se manter e, assim, tem como consequência o agravamento da estiagem. Diante desta situação, nos últimos meses de 2014, antes das primeiras chuvas do inverno de 2015, o tal buraco que jamais secara já não era mais um espelho d'água, mas uma lama de onde brotava apenas o capinzal de tabuba, sem peixes, impossibilitando a atividade da pesca, tão comum em todas as lagoas da região.

Daí o fato de eu ter escolhido o exemplo da Lagoa Verde para ilustrar minhas questões. As explicações sobre a falta d'águia na lagoa são muitas, a maioria das pessoas, quando questionadas sobre o assunto, diz apenas que Mãe d'Água resolveu mudar-se daquele local, pois a ação dos homens secou da lagoa e, por isso, tem afastado não só Mãe d'Água, mas vários outros encantados.

Com a escassez d'água na lagoa, os pescadores obviamente estavam impedidos de pescar nela no momento da minha pesquisa de campo. Havia apenas duas senhoras que, todos os dias iam até a lagoa colher tabuba para fazer esteiras. Fui apresentada a elas por Dona Maria Lídia, que, em uma das nossas muitas conversas sobre encantes, me chamou atenção para a necessidade de conhecer a lagoa e conferir, de perto, que ela nunca secava. Durante um tempo da sua vida, ela morou bem perto da lagoa e conhece bem as famílias que moram nos arredores, assim, me sugeriu fazer uma visita à casa das duas irmãs que moram ao lado da lagoa, mas alertou sobre o risco de elas não quererem contribuir com a pesquisa, pois não apoiam o movimento indígena, ainda que, conforme me relataram em seguida, se considerem "descendentes de índios". Todavia, ao contrário do que Dona Maria previu, elas foram bem 
receptivas e demonstraram muita simpatia pelo meu interesse na produção de esteiras de tabuba e pelo trabalho das duas na lagoa.

Dona Mazé e sua irmã, Dona Luísa, desde bem cedo, aprenderam o ofício da produção manual de esteiras. Ambas, embora tenham relações de parentesco bem próxima com os índios, "não se assumem" como Tremembé. Desde que o grupo começou a organizar-se enquanto movimento indígena, no final dos anos 80 , houve muitas divergências entre os que entraram na luta e resolveram "se assumir" como índios e os que, mesmo reconhecendo sua ancestralidade indígena, fato inegável às famílias que compõem o povoado, preferiram não aderir ao movimento político. Assim, a comunidade é dividida entre os "de fora" - ou seja, aqueles que não têm quaisquer vínculos de parentesco com a comunidade -, os índios e aqueles que são índios, mas "não se assumem". É muito comum, quando perguntamos se alguém é índio, a resposta "é, mas não se assume". Este é o caso das duas irmãs que colhem tabuba na lagoa. Ambas moram num terreno situado ao lado da Lagoa e levantam ainda de madrugada para iniciarem a confecção das esteiras. Mesmo morando ao lado, elas caminham vários metros para chegar alcançar as tabubas nascidas no meio da lagoa, onde ainda está mais úmido e elas têm uma maior qualidade para o fim da fabricação das esteiras. Pelo caminho, há muitas palhas se tabubas secas ao chão, de onde elas dizem emergir muitas cobras, principalmente no inverno, quando caminham pelo lugar com o corpo quase todo submerso, elas dizem que trabalham diariamente no meio das cobras, mas que nunca foram atacadas, pois a intenção do animal é tão somente subir em seus corpos para respirar um pouco, e que, logo em seguida, voltam para a água. Após a colheita da palha de tabuba, ela é estendida em estirões ao sol, para, depois de secas, serem amaciadas e trançadas, conforme revelam as imagens em anexo. Durante vários dias, eu chegava na casa das duas ainda no escuro da madrugada, para sair com elas para pegar tabuba na lagoa. Depois disso, voltávamos para casa e íamos preparar o almoço, enquanto eu procurava conversar sobre a vivência das duas no lugar. Depois do almoço, procurava dar uma volta pelas casas próximas, onde havia algumas 
pessoas que costumavam lá pescar até bem pouco tempo, antes de ela secar quase totalmente.

Em nenhum momento, durante todos esses dias, observei alguma prescrição em relação aos encantados por parte das duas, muito embora, quando eu tocasse no assunto, elas assegurassem que lá era, de fato, a morada de uma Mãe d'Água. Contavam muitas histórias de conhecidos que já as haviam garantido tê-la visto banhar-se naquelas águas. Ainda assim, diziam não temer a encantada, pois esta nunca as havia incomodado.

Passei então vários dias frequentando a Lagoa Verde e as casas da vizinhança, onde as pessoas contavam que se utilizavam da lagoa para banharem-se e pescarem, quando ela estava cheia. Outras lagoas que também foram contempladas estão situadas nas localidades da Batedeira, cuja a lagoa leva o mesmo nome da localidade e, na Tapera, a lagoa do Luís de Barros, onde também vive Mãe d'Água. Nessas duas localidades, entretanto, passei menos tempo e tive mais dificuldade de frequentar as pescarias, pois estas eram, na maior parte dos casos, empreendidas por homens, então, assim como as caçadas, é um terreno bem ardiloso para uma mulher sozinha, pois se trata de um ambiente essencialmente masculino. Assim como a pesca no mar, que nunca tive a oportunidade de presenciar pela mesma razão. Entretanto, tive a oportunidade de acompanhar algumas pescarias feitas por mulheres, especialmente na localidade da Passagem Rasa, como relatei no segundo capítulo.

$\mathrm{Na}$ visita às casas vizinhas à lagoa, as pessoas se mostravam muito impressionadas com a seca na lagoa, sobretudo porque, até então, a Mãe d'Água que lá mora nunca havia deixado faltar água. Uns me diziam que, ainda que a lagoa estivesse bastante seca e sem peixes, a Mãe d'Água ainda estava lá e, por isso, tinha conservado uma pequena poça d'água no meio da lagoa que, embora não fosse suficiente para a pesca, era suficiente para que ela pudesse realizar suas tarefas domésticas. Outros, no entanto, se mostravam desanimados frente à seca da lagoa e afirmavam que a Mãe 
d'Água já não mora mais ali, pois o que haveria de fazer um encantado em um lugar onde não há mais água?

Identifiquei, portanto, alguns modos de caracterização das moradas dos encantados. Há os que colocam tais moradas como inatingíveis, pois, ainda que não vejamos, os encantados preservam a natureza, assim, mesmo nos lugares mais atingidos pelo desmatamento, as matas encantadas e invisíveis continuam a existir. Seu Estêvão - um ancião, morador da Tapera - sobre o qual já falei aqui - me afirmou várias vezes que podia ver seus ancestrais vivendo nas áreas hoje tomadas pela Ducoco. Ele afirma que, embora os coqueirais tenham tomado conta de tudo, os ancestrais ainda vivem lá, em suas aldeias invisíveis e inatingíveis, plenas de cajueiros e animais para a caça.

A opinião de Seu Estêvao, entretanto, contraria a maior parte dos relatos que colhi em campo. A grande maioria dos habitantes de Almofala afirma que, em meio à crise gerada pelo avanço do agronegócio, os encantados estão mesmo se evadindo do local e indo em busca de outras áreas onde podem viver em meio à natureza. O que essa assertiva nos coloca sobre a ação dos encantados enquanto donos daqueles lugares? Ao que parece, esta versão é bem diferente de quando nos referimos aos donos, humanos. Quando nos colocamos enquanto donos, temos um domínio e uma propriedade sobre as coisas, os encantados são donos de determinada área enquanto as pessoas que por lá transitam os reconheçam e, mais do que isso, os respeitem como tal! Se os humanos não reconhecem, respeitam ou, simplesmente, ignora a presença de encantados, ambos - humanos e encantados - sofrerão as consequências. Muito embora os primeiros, muitas vezes, não saibam reconhecer as retaliações lançadas pelos encantados. 


\section{Conflitos ontológicos na Almofala dos Tremembé}

Isso significa que encantados não têm o poder de afastar todos os humanos nem de garantir a preservação dos recursos à revelia das ações humanas. Embora eles castiguem os humanos que desrespeitam, de algum modo, suas moradas, a maioria dos humanos sequer sabe da sua existência, e, portanto, ignora suas ações. Em uma das conversas que tive com Seu Estêvão, ele me disse que sentia pena dos donos da Ducoco pelo que eles ainda sofreriam nessa vida e, também, após a morte pela devastação provocado naquelas matas. Eles sofriam de doenças ou outros males lançados pelos encantados, mas, por ignorarem a existência de planos e agências encantadas, não atribuiriam seus males às ações dos habitantes invisíveis das matas.

No decorrer de toda a pesquisa de campo, pude perceber a preocupação com a ignorância dos não índios em relação às forças da natureza. O episódio ocorrido na audiência pública sobre as eólicas, protagonizado por Getúlio sobre estradas e raposas ilustra bem isso. No final da audiência, quando conversamos, ele não se mostrava irritado com a réplica da representante da empresa, apenas lamentava sua ignorância a respeito das relações estabelecidas ali entre humanos e raposas, relações que envolviam - mal sabia a moça... - uma pluralidade de entidades, mundos e subjetividades que conviviam naquelas matas.

O Cacique João Venâncio me repetia sucessivas vezes durante nossas conversas: "a natureza é viva!". Entretanto, lamentava ele, os empresários que atuam na área não sabem de nada sobre as muitas entidades que habitam lugares como matas, mangues e águas, por isso acham que podem valer-se deles de forma inconsequente.

A mesma preocupação é apontada por Davi Kopenawa (2010) onde o xamã lança suas palavras para serem ouvidas pelos brancos na esperança de que saiam da ignorância sobre os riscos de que o céu caia sobre as nossas cabeças como consequência das ações predatórias sobre a floresta. 
Os conflitos ontológicos entre os Tremembé não estão, somente, relacionados aos processos de urbanização e avanço do agronegócio. A adesão a religiões protestantes tem sido cada vez maior entre as famílias da região, especialmente pela ação de missionários evangélicos. A casa na qual eu me hospedava, inclusive, era de uma família de crentes, como se auto aclamavam.

O cotidiano dessa família é diferente daquele da maioria das famílias que compõem o grupo, nas quais as mulheres, em geral, dedicamse às atividades domésticas - dificilmente encontramos alguma mulher que tenha trabalho formal, até mesmo porque os empregos formais no lugar ainda são bem raros. Neste caso, porém, a Dijé é a principal responsável pelo orçamento familiar, já que é viúva há quase dez anos. Desde que seu marido faleceu, ela vive com seis dos seus sete filhos - dois homens de vinte e poucos anos e quatro moças, de idade entre vinte e poucos a doze anos - e um neto de menos de dois anos. O mais velho deles é casado e mora com mulher e filhos numa localidade próxima. Já o outro rapaz vive com a mãe e as irmãs e também trabalha como agente sanitarista. As moças dedicam-se às atividades domésticas e aos estudos, na Escola Maria Venância, situada a poucos metros de sua casa.

Como já mencionei neste trabalho, desde que os conheci e passei a hospedar-me na sua casa, suas filhas me ajudavam muito nas minhas tarefas de campo, pois me acompanhavam nas minhas caminhadas, orientando-me em meios aos caminhos muitas vezes tortuosos por entre matas e dunas e me apresentado a outras famílias na vizinhança. Quando nós visitávamos algumas casas, como a de Dona Maria Bela, por exemplo, elas se sentavam nas tucuns armadas no terreiro e se punham a ouvir, junto comigo, as histórias sobre suas curas e outros feitos que envolviam os encantes. Quando cheguei em campo para a pesquisa de doutorado, não foi muito diferente. Ao apresentar o tema da minha pesquisa, elas indicaram várias pessoas que poderiam discorrer sobre o assunto, mas me alertaram que essas histórias sobre encantados não eram "verdadeiras", pois o único ser que governa todo o universo é Deus, assim Ihes assegurava o pastor da 
igreja que passaram a frequentar nos últimos anos. O pastor é ligado à Missão Novas Tribos do Brasil, que atua na área há aproximadamente quinze anos.

Em 2002, na primeira vez que estive em Almofala, havia dois casais que moravam na área. Uma das mulheres era professora voluntária da Escola Maria Venância, onde dava aulas para a pequena turma de alunos da quarta série. Além de abordar o currículo convencional, ela também "evangelizava" as crianças, trabalho que consistia em abordar textos bíblicos, ensinar cantos evangélicos e transmitir a elas os preceitos da Igreja Batista. Dentre tais preceitos estava a proibição de "adorar falsos deuses", fossem eles santos, encantados ou Nossa Senhora da Conceição, santa padroeira do lugar.

Logo que começaram a atuar na área, os missionários construíram um pequeno galpão de alvenaria no centro da aldeia, onde eram - e ainda são - realizados os cultos. Tratava-se de um galpão de alvenaria, com piso de cimento, medindo aproximadamente uns $40 \mathrm{~m}^{2}$, com um pequeno banheiro, portando como mobília apenas um oratório para o pastor e algumas cadeiras de plástico. Não há quaisquer adornos ou imagens, pois estas também se enquadram na categoria de "falsos deuses", já que o "deus verdadeiro" não poderia ser ilustrado em imagens, uma vez que pessoa alguma the conhecia as feições.

Estas interdições impetradas pelos pastores são frequentemente tema de muitas discussões nas Assembleias Indígenas. As duas maiores lideranças da Área, cacique João Venâncio e pajé Luís Caboclo, afirmam que a atuação de "seitas" como se referem a tais práticas em seus discursos, visa enfraquecer a "cultura" indígena, na medida em que restringem a participação dos seus membros em rituais tais como as práticas curativas das rezadeiras e, o que é mais contestado, o ritual do torém. Por outro lado, as lideranças evangélicas - como Dijé, por exemplo - argumentam que os pastores sabem respeitar a "cultura" dos Tremembé e se coloca como prova disso, já que ela, mesmo sendo crente, como se autointitula, continua a dançar torém e beber o mocororó. Mas o fato é que o ritual do torém ocorre 
em momentos festivos, regados à bebida alcoólica e brincadeiras, se é vetado aos crentes a participação em festas e o consumo de bebidas alcoólicas, participar do torém torna-se uma contradição para eles, embora seja "liberado" pelo pastor. Além desse exemplo, o cacique costuma falar das práticas rituais curativos das rezadeiras que ele reconhece como sendo um elemento essencial da "cultura" dos Tremembé e fonte de conhecimento sobre as plantas medicinais da região e que é depreciada pelos pastores, que orientam pais e mães a não procurar rezadeiras ou pajés que, segundo eles, mobilizam falsos deuses nas suas práticas.

Atualmente, muitas das famílias indígenas da região da Praia de Almofala, são crentes. A maioria das crianças que eram alunas da professora missionária há mais de uma década está casada e com filhos e muitas delas continuam frequentando os cultos até hoje, entre elas as quatro filhas da Dijé.

Por tais razões, e também porque nenhum dos membros da família da Dijé, realiza qualquer atividade nas matas, mares ou quaisquer lugares que poderia servir de moradas a encantados, eu imaginava que a convivência com sua família não me renderia muitas informações sobre meu principal interesse em campo. Por isso, optava por ficar hospedada na sua casa, como já estava habituada, mas passava boa parte dos meus dias fazendo visitas nas casas da vizinhança, pois, interlocutores essenciais para a pesquisa moravam perto ou não muito longe de sua casa, como, por exemplo, Dona Maria Bela, ainda na Praia; Dona Zeza e Dona Maria Lídia, no Panã, Dona Neném Beata, no Mangue Alto...

$\mathrm{Na}$ volta para casa, no final da tarde, costumava fazer uma caminhada na beira do mar, atividade na qual uma das filhas da minha anfitriã, Quitéria, era minha companhia mais fiel, não só pela sua imensa disposição e apreço pelas caminhadas pelo lugar, como porque precisava realizar, por orientações médicas, caminhadas diárias com o objetivo de perder peso. Praticamente todos os dias - salvo quando eu chegava em casa após o cair da noite - fazíamos longas caminhadas na Praia, combinada com longas conversas sobre os mais variados assuntos. Quitéria é uma 
adolescente de 16 anos, muito atenta às histórias que sua mãe conta e de quem herdou uma habilidade narrativa incrível. Em todas as nossas caminhadas, ela mostrava atentamente os animais que achávamos pelos caminhos - uma variedade inumerável de crustáceos, mariscos e peixes que encontrávamos sobre a areia da praiaEm um desses momentos de disposição para longos percursos a pé, ela se dispôs e mostrar-me o lugar, no mangue, onde ela, a mãe e as irmãs iam, vez por outra, coletar búzios. Contava-me que, quando o pai era vivo, ele a alertava sobre como deveria se comportar em lugares como o mangue, pois ele era habitado por seres das matas que não gostavam de ser perturbados. Ela, por sua vez, me repassava tais recomendações. Dizia que, muitas vezes, quando as mulheres se empolgavam nas conversas durante a coleta dos mariscos, seu pai as repreendia, pois, caso os encantados que ali viviam se sentissem incomodados com a presença humana e, por algum motivo, interpretasse suas atitudes como uma falta de respeito com eles ou com os lugares, poderiam sofrer alguma retaliação.

Os passeios no mangue para coletar mariscos me renderam alguns dos momentos mais descontraídos e, também, muitas insolações, pois, diferente das mulheres que iam preparadas para a exposição ao sol, com roupas de mangas compridas, eu sempre confiava no protetor solar que nunca era suficiente para dar conta das muitas horas que passávamos debaixo do sol. O fato sempre arrancava risos das mulheres quando voltávamos para casa e eu estava, segundo elas, mais corada que os siris que haviam caçado. Esses momentos de convivência serviam, sobretudo, para aproximar-me ainda mais das mulheres e fortalecer os laços entre nós, pois, nessas ocasiões, passávamos as manhãs conversando sobre nossas vidas, nossos projetos e trocávamos várias experiências. Depois de tantos anos de convivência com os Tremembé, já aprendi a andar com desenvoltura pelo terreno escorregadio do mangue e já perdi o medo de enfiar a mão na lama dos manguezais para desenterrar os búzios, embora ainda não tenha coragem nem habilidade suficiente para caçar os caranguejos e siris com as próprias mãos, como as mulheres e mesmo as 
crianças fazem. Mesmo porque, em todas as minhas tentativas, os animais acabaram levando vantagem, o que também provocava o riso de mulheres e crianças. Muitas das mulheres, mesmo sendo crentes, me contavam muitas histórias sobre os encantes dos mangues.

A concepção de que aqueles locais são habitados por seres encantados é algo que está para além das adesões religiosas. Ainda que algumas pessoas - sejam crentes ou católicos - recusem-se, ainda que no plano do discurso, a reconhecer a existência e a agência de seres encantados, são afetadas por suas ações, querendo ou não.

Ainda que alguns se recusem a recorrer aos encantados mesmo nos momentos de aflição, há alguns episódios em que estas mesmas pessoas se veem diante da fatalidade em admitir a existência deles. Lembro de uma conversa que tiver certa vez com uma moça evangélica que me contou que há várias semanas sua família acordava nas quartas-feiras com som do choro de uma criança que vinha dos matos, nos arredores de casa. Ela me explicou que estavam à procura de algum rezador ou rezadeira que pudesse ir até lá para rezar no choro e acabar com a aflição do anjinho e, também, com a sensação de medo, estranhamento e dó que provocava a audição deste triste lamento.

Assim, a convivência com quaisquer famílias, sempre me traziam novas informações sobre os sujeitos desta pesquisa. Com o tempo, fui percebendo que, mais do que frequentar os lugares indicados como moradas de encantados, eu deveria estar atenta às revelações sobre eles que poderiam surgir a qualquer momento e em qualquer lugar.

Contudo, priorizar as perambulações por lugares apontados como moradas de encantados foi-me bastante útil, mesmo porque, ainda que eu estivesse menos "ansiosa" pelas manifestações ou menções aos encantados e estivesse mais atenta ao que o cotidiano entre as famílias poder-me-iam revelar, fez-me ver as relações que diferentes atores estabelecem com os lugares e as mais diversas agências que nele atuam. 


\section{CONSIDERAÇÕES FINAIS}

As considerações finais da tese não apontam para uma conclusão, pois meu intuito aqui foi muito mais levantar questões do que propriamente respondê-las. O que espero aqui é ter aberto as portas de um universo encantado pleno de mundos que podem coexistir no mesmo plano espacial, mas são constituídos por modos de existência diferentes em matéria e temporalidades.

Os encantados não estão em uma realidade paralela ou em um mundo sobrenatural. Ao contrário, convivem lado a lado com os humanos, observam, ajudam, orientam. Suas formas de existência lhes conferem corpos que se transformam e se tornam visíveis ou não, a depender das circunstâncias.

As ações dos encantados estão direcionadas à manutenção de um equilíbrio que depende da separação entre os nossos mundos e os mundos encantados. A preservação das matas, águas e todos os outros lugares plenos de encante só é possível se respeitarmos o mistério inerente a eles. Isso foi evidenciado em vários dados expostos na tese, nos quais os interlocutores afirmam que devemos cumprir alguns preceitos para circular pelas possíveis moradas de encantados com o espírito forte e protegido das possibilidades de contato com entidades não humanas que nos podem levar consigo. Ao mesmo tempo, estar forte pode abrir as portas para compreender os segredos das curas revelados lenta e cuidadosamente pelos encantados. O conhecimento sobre as moradas dos encantados e os recursos que elas provem se constitui, portanto, nas relações estabelecidas entre as mais diversas entidades que circulam pelas matas, águas a areais.

Em muitas ocasiões, observei que, mesmo aquelas pessoas que sequer mencionavam os encantados quando estavam em suas possíveis moradas, muito menos cumpriam quaisquer prescrições como oferecer fumo ou benzer-se ao atravessar as cercas, estavam atentas às suas manifestações. Durante vários dias em que acompanhei as pescarias de Hosana e sua família, por exemplo, jamais percebi nenhuma preocupação 
dela nesse sentido. Às vezes adentrávamos no manguezal, em meio a uma mata densa que tornava impossível que nos avistássemos quando nos afastávamos um pouco uns dos outros. Nessas ocasiões, para se encontrarem e orientarem, os Tremembé se comunicam por gritos rápidos e agudos - Uh!. Deste modo, guiados pelo som da voz, conseguem se reencontrar. Certa vez, estando pescando com Hosana começamos a ouvir gritos, ela, então, pediu silêncio de todos e questionou "será que é gente?". $\mathrm{Na}$ medida em que os gritos iam-se tornando mais altos, avisando que seu emissor se aproximava, ela concluiu "é gente sim! Se não fosse, eu estaria arrepiada!". De fato, era sua filha que resolveu nos acompanhar na pescaria e tentava nos encontrar em meio à vegetação do mangue. Quando eu questionei sobre o que faríamos caso ela percebesse que não se tratava de gente, ela respondeu que, se tivesse sentido arrepios, seria um sinal de que se tratava de "alguma coisa do outro mundo", portanto, deveríamos ir embora dali imediatamente, caso contrário, poderíamos sofrer alguma retaliação por parte da entidade que se estava manifestando.

Nem todos os humanos, entretanto, cumprem tais prescrições. Uns a desconsideram, outros apenas as desconhecem. Assim, embora sofram retaliações, não as atribuem às ações dos encantados, pois partem de pressupostos ontológicos que não consideram as agências daqueles lugares nem das múltiplas subjetividades que os povoam, por isso, muitas vezes as ações dos encantados não são suficientes para conter o avanço da destruição das suas moradas e eles preferem se mudar de lugar para onde haja possibilidade de viverem em meio aos elementos da natureza.

\section{Tempo dos encantados}

Mesmo os relatos que apontam para o desaparecimento - ou quase - dos encantamentos da região de Almofala, alertam que, embora os encantados fiquem incomodados com a destruição de suas moradas, 
eles têm a possibilidade de se mudar para planos de existência onde a natureza nunca se acaba.

As narrativas e episódios que expus ao longo da tese apontam para a origem do mundo, para um tempo, quando havia reinos encantados, com fadas, príncipes, princesas ou mesmo pessoas comuns que tinham o dom de se encantar e, depois de encantados, levar os mortais consigo, conforme relatam alguns trechos de entrevistas que transcreverei em seguida, como esta conversa que tive com Dona Maria Lídia:

Juliana: e esses encante são o que, Dona Maria, é gente que morre, é gente que se encanta, o que é?...

Maria Lídia: não, é porque antigamente tinha muita fada e as fada se engraçavam deles, do príncipe ou da princesa, aí encantava eles. Minha fia, eu acredito que, naqueles tempo, era cuma agora, o pessoal não fala em feitiço, né, que é pra... a macumba? (...) e eles fazem aqueles trabalho com fumo, fumando, com a cachaça, com a pólvora, com o álcool, eles fazem aquelas roda dentro e ficam sapateando. Eu acredito que, naqueles tempo, era como esses tempo agora. Às vezes querem tirar um rapaz de uma moça, aí vem fazerem essas coisa. Era como naquele tempo também, é do mesmo jeito, tinha os encante, os encantado, os poder, tinha aquelas força, daquela magia. Agora eu acredito que hoje não tem mais força não, não se tem não.

Na conversa que gravamos, eu e Marcos Messeder, quando conhecemos Dona Maria Bela, ela também se refere ao tempo dos reinos encantados:

Marcos: e esses índio, esses caboclo, esses príncipes são todos encantado? Não é espírito de morto?

Maria Bela: é não, não é espírito de morto. Quer dizer, que tem algum morto por aí, mas... como eu pensava que o mestre Luis era morto, mas ele não é morto, a mãe dele teve ele e jogou na água e as mãe d'água pegaram a criança e aí criaram, né? Eu pensei que mestre Luis era morto, mas não é. O primeiro encantado do mundo foi Dom Carlos, Mestre Carlos. Mestre Carlos foi o primeiro encantado do mundo e foi encantado pela Fada de Borborema. A Fada de Borborema, ela não faz mal a ninguém, é uma fada muito boa. Agora aquela fada, Zoraína, aquela fada, ela fez muita...

Marcos: tem uma fada chamada Zoraína?

Maria Bela: Zoraína, ela que encantou a princesa Rosa Mundo.

Marcos: e Rosa Mundo é uma princesa... 
Maria Bela: é uma princesa também que ela encantou.

Marcos: e isso é num tempo que...

Maria Bela: nos tempos antigo, daqueles reinado, daquelas coisa toda.

Marcos: esses reinado era tudo encantado?

Maria Bela: os reinado que se encantava, né?

Os Tremembé não negam a passagem do tempo, muito pelo contrário, a afirmam recorrentemente, quando descrevem as transformações às quais vêm sendo submetidos. Em contrapartida, os mundos encantados apresentam a existência de um plano onde paira o equilíbrio e o respeito. Quando conversava com as entidades nos terreiros das pajés, como no caso já exposto no trabalho de Seu Chico Brega, elas me afirmavam viver em lugares plenos de natureza, onde havia sempre uma enorme fartura de frutas e animais para caça.

Nas descrições de Dona Maria Bela sobre as moradas erguidas por encantados ela também descrevia enormes castelos de ouro plenos de personagens da realeza. Além disso, a passagem do tempo é anulada frente à imensidão da eternidade.

Para compreendermos a ideia de tempo para os Tremembé é preciso fazer um esforço, portanto, para desnaturalizar a noção de tempo preponderante na sociedade ocidental - que tende a tomá-lo como algo objetivo, dado em si mesmo, numa perspectiva teleológica. Sobretudo após a Revolução Industrial, a concepção de tempo que impera nas sociedades modernas, remete à noção de progresso; um tempo que caminha sempre para frente, percorrendo um caminho linear. Entretanto, é importante que concebamos a ideia de tempo é mutável e fluida.

No caso dos Tremembé, os relatos sobre os encantados revelam uma noção na qual a irreversibilidade da direção do tempo (do passado ao futuro, passando pelo presente) não faz sentido, pois estas categorias parecem coexistir. São muitas as narrativas nas quais os pajés conseguem transportar-se para um tempo futuro ou passado, na mesma medida em que não saem da dimensão do presente. Os mundos dos encantados 
permitem aos entes que por ele circulam driblarem as peripécias de um tempo irreversível. 


\section{REFERÊNCIAS BIBLIOGRÁFICAS}

ALARCON, Daniela Fernandes. O Retorno da Terra: as retomadas na aldeia Tupinambá da Serra do Padeiro, Sul da Bahia. Dissertação de Mestrado apresentada ao Programa de Pós-Graduação em Estudos Comparados sobre as Américas do Instituto de Ciências Sociais da Universidade de Brasília. 2013.

ALBERT, B. RAMOS, Alcida Rita. Pacificando o Branco: cosmologias do contato no norte-amazônico. São Paulo. Editora UNESP, 2002.

ALMEIDA, Alfredo Wagner Berno de. Terras Tradicionalmente Ocupadas: Processos de Territorialização e Movimentos Sociais. In: Revista Brasileira de Estudos Urbanos e Regionais Publicação semestral da ANPUR. Vol. 06. No 01. Maio de 2004.

AMOROSO, Marta Rosa e SANTOS, Gilton M. dos. Paisagens Ameríndias: lugares, circuitos e modos de vida na Amazônia. São Paulo, Terceiro Nome. 2013.

ANDRADE, Ugo Maia. O real que não é visto: xamanismo e relação no baixo Oiapoque (AP). Tese de Doutorado, São Paulo, Universidade de São Paulo. 2007.

BASSI, Flávio. "Saberes na encruzilhada: experiências e sentidos da indigenização da "cultura" no Brasil e no Pacífico". Primeiros Estudos. N.2. 2012.

BONILLA, Oiara. Cosmologia e organização social dos Paumari do médio Purus (Amazonas). In: Revistas de estudos e Pesquisas, FUNAI, Brasília, v.2, n.1, p.7-60. 2005.

- O bom patrão e o inimigo voraz: predação e comércio na cosmologia paumari. In: Mana, v.11, n.1, p.41-66. 2005.

BRASILEIRO, Sheila. A organização política e o processo faccional no povo indígena Kiriri. Salvador, Dissertação de Mestrado, Mestrado em Sociologia, Universidade Federal da Bahia. 1996.

CAVALCANTE, Gustava B. A natureza encantada que encanta: histórias de seres dos mangues, rios e lagoas narradas por índios Tapeba. Tese de Doutorado. Doutorado em Sociologia, Universidade Federal do Ceará. 2010.

CHAVES, Luis de Gonzaga Mendes. Trabalho e Subsistência - Almofala: aspectos da tecnologia e das relações de produção. Dissertação de Mestrado. Programa de Pós-Graduação em Antropologia Social da Universidade Federal do Rio de Janeiro, 1973.

CESARINO, P. N. "Donos e duplos: relações de conhecimento, propriedade e autoria entre Marubo". Revista de Antropologia, vol. 53, n 1. 
CERTEAU, Michel de. A Invenção do Cotidiano: 1. Artes de fazer. Petrópolis: Vozes, 2008.

COUTO, Patrícia Navarro. Morada dos Encantados: identidade e religiosidade entre os Tupinambá da Serra do Padeiro. Dissertação de Mestrado apresentada ao Programa de Pós-Graduação em Ciências Sociais da Universidade Federal da Bahia, 2008.

CUNHA, Manuela Carneiro da. Antropologia do Brasil: mito, história e etnicidade. São Paulo: Brasiliense, 1986.

CosacNaify, 2009. - Cultura com aspas. São Paulo:

DANTAS, Beatriz Góis., SAMPAIO, José Augusto L. e CARVALHO, Maria do Rosário G. Os Povos Indígenas do Nordeste Brasileiro: um esboço histórico. IN: CUNHA, Manuela Carneiro da (org.). História dos Índios do Brasil. São Paulo: FAPESP / SMC / Cia. das Letras, 1992.

DESCOLA, P. Ecologia e Cosmologia. In: DIEGUES, Antônio Carlos. Etnoconservação - novos rumos para a proteção da natureza nos trópicos. São Paulo, Hucitec, 2000.

- La Nature Domestique: symbolisme et praxis dans I'ecologie dês Achuar. Paris: Ed. de la Maison dês sciences de I'homme, 1986. . Par delà nature et culture. Paris : Gallimard, 2005.

DOUGLAS, Mary. Pureza e Perigo. São Paulo: Perspectiva, 1976.

ELIAS, Norbert. Sobre o Tempo. Rio de Janeiro: Jorge Zahar, 1998.

FAUSTO, Carlos. "Donos demais. Maestria e domínio na Amazônia. Mana 14(2):329-366. 2008.

GALLOIS, Dominique T. Cultura "indígena" e sustentabilidade: alguns desafios. In: Tellus, ano 5. n 8/9, p. 29-36. 2005

. Terras Indígenas? Territórios? Territorialidades?

In: RICARDO, F.Terras indígenas e unidades de conservação da natureza: o desafio das sobreposições. São Paulo: Instituto Sócioambiental, 2004.

. O movimento na cosmologia waiãpi: criação, expansão e transformação do mundo. Tese de Doutorado, São Paulo, Universidade de São Paulo. 1988.

São Paulo: Associação (org). Redes de relações nas Guianas (vol II). Editorial Humanitas / FAPESP. 2005.

"Donos, detentores e usuários da arte gráfica kusiwa". Comunicação. ABA, 2010.

GONDIM, Juliana M. Dona Maria Bela: suas curas e seus encantes. Monografia de graduação em Ciências Sociais, UFC, 2007. 
. "Não tem caminho que nós não ande e nem tem mal que nós não cure": narrativas e práticas rituais das pajés tremembés. Dissertação de Mestrado., apresentada ao Programa de Pós-Graduação em Sociologia da Universidade Federal do Ceará. 2010.

GONGORA, Majoí Favero. No Rastro da Cobra Grande - variações míticas e sóciocosmológicas: a questão da diferença na região das Guianas. Dissertação de Mestrado, apresentada ao Programa de Antropologia Social da Universidade de São Paulo. 2007.

GRUPIONI, Luis Donisete Benzi. VIDAL, Lux Boelitz e FISCHMAN, Roseli. Povos indígenas e tolerância: construindo práticas de respeito e solidariedade. São Paulo: EDUSP, 2001.

INGOLD, Tim. The Perception on the Environment: Essays on livelihood, dwelling and skill. London and New York: Routledge, 2000.

KIRSCH, Stuart. Reverse Anthropology: indigenous analysis of social and environmental relations in New Guinea. Stanford University Press: Stanford, 2006.

KOPENAWA, Davi \& ALBERT, Bruce. La chute du ciel : paroles d'un chaman yanomami. Paris: Terre Humaine, Plon, 2010.

LATOUR, Bruno. Jamais fomos modernos: ensaio de antropologia simétrica. São Paulo: Editora 34, 1994.

Enquête surles modes d'existence: une anthropologie des modernes. Paris : La Découverte, 2012.

LEACH, E. E. "Dois ensaios a respeito da representação simbólica do tempo". In: Repensando a Antropologia. São Paulo: Perspectiva, 1974.

LIMA, Tânia S. "O Dois e seu Múltiplo: reflexões sobre o perspectivismo numa cosmologia tupi", Mana 2 (2): 21-47. 1996.

Um Peixe Olhou Para Mim. O povo Yudjá e a perspectiva. São

Paulo: UNESP/ ISA/ NUTI. 2005.

MAUSS, Marcel. Ensaio sobre a dádiva. In: Sociologia e Antropologia. São Paulo: EDUSP, 1974.

MESSEDER, Marcos Luciano. Etnicidade e Diálogo Político: e emergência dos Tremembé. Dissertação de Mestrado apresentada ao Programa de PósGraduação em Ciências Sociais da Universidade Federal da Bahia, 1995.

chez les Tremembé. Lyon, Université Lumière Lyon 2. (Tese de Doutorado). 2004.

MOL, Annemarie. The Body Multiple: ontology in medical pratice. Durham and London. Duke University Press, 2002. 
MUNN, Nancy D. "The Cultural Anthropology of Time: A Critical Essay." Annual Review of Anthropology21 (1992): 93-123.

NASCIMENTO, Marco Tromboni de Souza. O Tronco da Jurema. Ritual e Etnicidade entre os Povos Indígenas do Nordeste : o caso Kiriri. Salvador, Dissertação de Mestrado, Universidade Federal da Bahia, 1994.

NOVO, José Silva. 1976. Almofala dos Tremembés. Itapipoca: /s.n.

OLIVEIRA, Joana Cabral de. Entre Plantas e Palavras: modos de constituição de saberes entre os Waiãpi (AP). Tese de Doutorado, apresentada ao Programa de Antropologia Social da Universidade de São Paulo. 2012.

. "Vocês sabem porque vocês viram : reflexões sobre modos de autoridade do conhecimento". Revista de Antropologia, v. 55, n. 1, 2012.

OLIVEIRA, João Pacheco de. Uma etnologia dos 'índios misturados'? Situação colonial, territorialização e fluxos culturais. In: Mana, 1998. . (org.) A Viagem da Volta: etnicidade, política e reelaboração cultural no Nordeste indígena. Rio de Janeiro: Contra Capa, 1999a. . Ensaios em Antropologia Histórica. Rio de Janeiro: Ed. UFRJ, 1999b.

OLIVEIRA, Kelly Emanuelly de. Guerreiros do Ororubá - o processo de organização política e elaboração simbólica do povo Xucuru. João Pessoa. Dissertação de Mestrado, Mestrado em Sociologia, Universidade Federal da Paraíba. 2006.

OLIVEIRA Jr., Gerson Augusto de. Torém: a brincadeira dos índios velhos reelaboração cultural e afirmação étnica entre os Tremembé de Almofala. Fortaleza: 1997. PPG-Sociologia / UFC (Dissertação de Mestrado).

- O Encanto das Águas: a relação dos Tremembé com a natureza. Fortaleza: Museu do Ceará, 2006.

PAIVA E SOUZA, Vânia R. Fialho de. As Fronteiras do Ser Xucuru estratégias e conflitos de um grupos indígena no Nordeste. Recife, Dissertação de Mestrado, Mestrado em Antropologia, Universidade Federal de Pernambuco. 1992.

POMPEU SOBRINHO, Thomaz. Índios Tremembés. In: Revista do Instituto do Ceará. Tomo LXV. Fortaleza: Instituto do Ceará. 1951.

POSTIGO, Augusto de Arruda. A Terra vista do alto: usos e percepções acerca do espaço entre os moradores do Rio Bagé, Acre. Tese de Doutorado em Antropologia Social, São Paulo, Universidade de Campinas. 2010. 
RATTS, Alecsandro J. Prudêncio. Fronteiras Invisíveis: territórios negros e indígenas no Ceará. São Paulo. PPG Geografia, Universidade de São Paulo. Dissertação de Mestrado. 1996.

SANTOS-GRANERO, Fernando. Arawakan sacred landscapes. Emplaced myths, place rituals and the production of the locality in Western Amazonia. In: Ernest Halbmayer \& Elke Mader (eds), Kultur, Raum, Landchaft. Zur Bedeutung des Raumes in Zeiten der Globalität, p. 93-122. Frankfurt am Main: Brandes \&Apsel Verlag, 2004.

. Writing History into the landscape: space, myth and ritual in contemporary Amazonia. In: American Ethnologist 25 (2): 128-148.1998.

SERAINE, Florival. Sobre o Torém. In: Revista do Instituto do Ceará. Fortaleza: Instituto do Ceará, 1955.

SILVEIRA, Pedro Castelo Branco. Etnografia da Paisagem: natureza, cultura e hibridismo em São Luis do Piratinga. Tese de Doutorado, São Paulo, Universidade Estadual de Campinas. 2008.

SOUSA, Marcela Stockler Coelho de. Três nomes para um sítio só: a vida dos lugares entre os Kïsêdjê (Suyá). IV Congresso da Associação Portuguesa de Antropologia Painel Convidado VII: Classificar: objectos, sujeitos, acções - 2009.

A cultura invisível: conhecimento indígena e patrimônio imaterial. Anuário Antropológico. 2009/1, pp. 149174.

SOUZA, Fabiano José Alves de. Morte, encantados e virados e suas reverberações sobre a noção Pataxó de "gente". Trabalho apresentado na $28^{a}$ RBA, 2012.

SOUZA, Jorge Bruno Sales. Fazendo a Diferença - um estudo da etnicidade entre os Kaimbé de Massacará. Salvador. Dissertação de Mestrado, Mestrado em Sociologia, Universidade Federal da Bahia. 1996.

SOUZA, M. Bruhilda. Mitos e símbolos na migração praiana - O caso de Almofala. Fortaleza, Dissertação de Mestrado, Mestrado em Sociologia, Universidade Federal do Ceará. 1983.

STENGERS, Isabelle. "La proposition cosmopolitique". In: Lolive, Jacques \& Soubeyran, Olivier (eds.). L'émergence des cosmopolitiques. Paris: La Découverte, 2007, pp. 45-68. . Cosmopolitiques I. Paris: La Découverte, 1997

STENGERS, Isabelle \& PIGNARRE, Philippe. La sorcellerie capitaliste. Pratiques de désenvoûtement. Paris, La Découverte, 2005. 
STUART FILHO, Carlos. "Os Aborígenes do Ceará". In: Revista do Instituto do Ceará, tomo LXXVII. Fortaleza: Instituto do Ceará. 1963.

SZTUTMAN, Renato. O Profeta e o Principal: a ação política ameríndia s seus personagens. EDUSP, FAPESP, 2012.

TAMBIAH, S. J. "Conflito etnonacionalista e violência coletiva no sul da Ásia". In: RBCS, n. 34, v.12, junho, 1997.

VALLE, Carlos Guilherme O. do. Terra, tradição e etnicidade: os Tremembé do Ceará. Rio de Janeiro, PPGAS / MN / UFRJ (Dissertação de Mestrado). 1993.

VELHO, Otávio, De Bateson a Ingold: passos na constituição de um paradigma ecológico. In: Mana, n 07. V. 02, 2001.

VIVEIROS DE CASTRO, E. A inconstância da alma selvagem e outros ensaios da antropologia. São Paulo: Cosac Naify, 2011.

. "A floresta de cristal: notas sobre a ontologia dos espíritos amazônicos". Cadernos de campo. 2015.

- Pronomes cosmológicos e perspectivismo ameríndio. In: Mana, n 02. V. 02, 1996.

O nativo relativo. In: Mana, $\mathrm{n}$ 01. V. 08, 2002. 
Anexos 


\section{Anexo 01}

Mapa da Terra Indígena Tremembé de Almofala

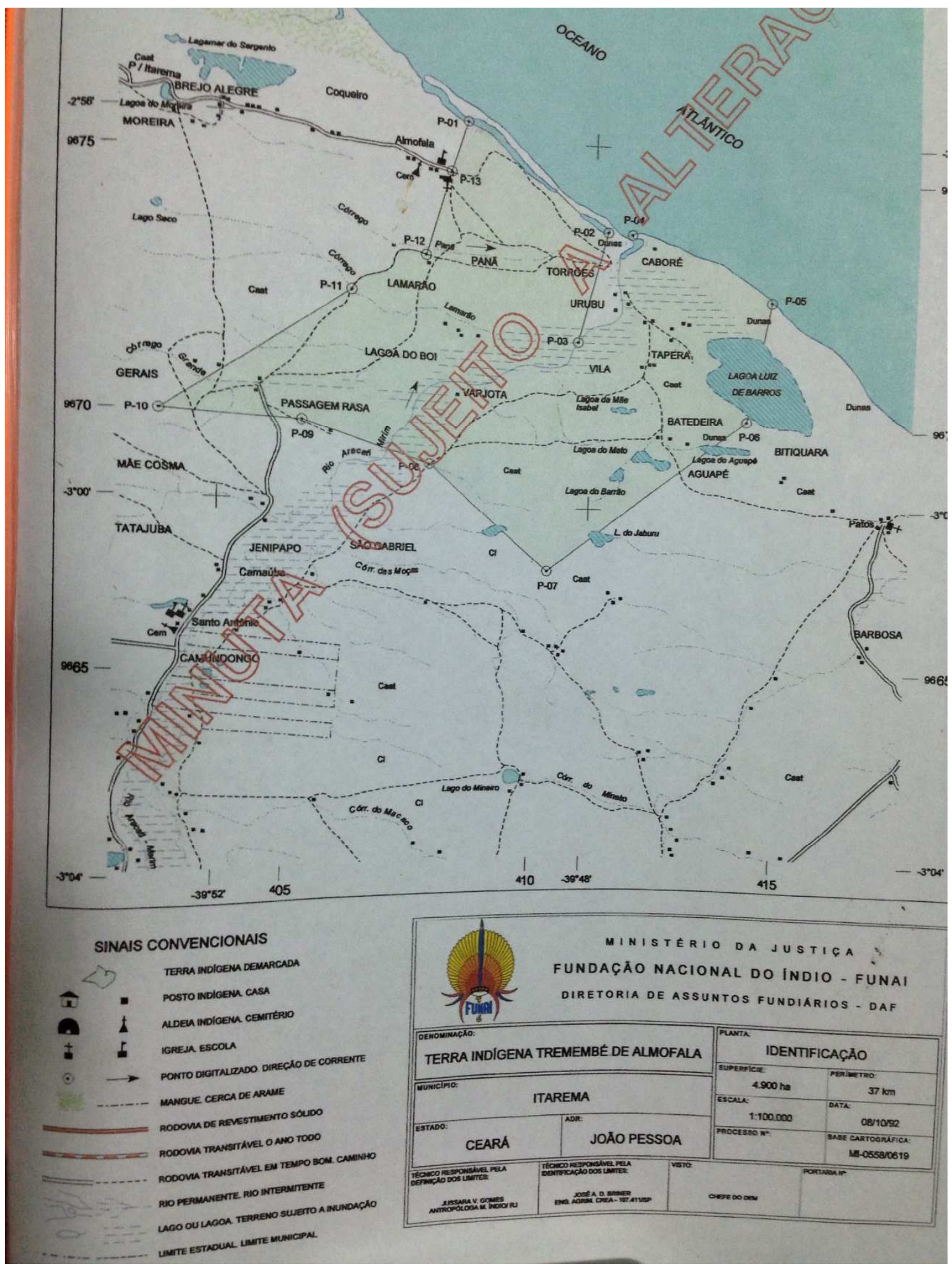




\section{Anexo 02}

Cronograma da pesquisa de campo

\section{Etapa I}

- Período - de 14 a 18 de junho

Atividades - organização do material de campo, compra de alguns itens que faltavam para minha chegada, inclusive a passagem até a Praia de Almofala.

Município: Fortaleza/Ce

- Período - de 18 de junho a 28 de julho.

Atividades - pesquisa de campo nas seguintes localidades: Praia de Almofala, Mangue Alto, Panã e Barro Vermelho.

Município - Itarema/ Ce.

- Período - de 29 a 31 de julho de 2013.

Atividades - visita à Aldeia de São José.

Município - Itapipoca/Ce

- Período: 09 de agosto a 08 de setembro.

Atividades - pesquisa de campo nas seguintes localidades: Praia de Almofala, Mangue Alto e Passagem Rasa.

Município - Itarema/Ce.

- Período - de 08 a 20 de setembro.

Atividades - pesquisa de campo nas seguintes localidades: Varjota, Tapera e Batederia. (Região das Matas)

Município - Itarema/Ce.

\section{Etapa II}

- Período - de 13 de outubro a 02 de novembro.

Atividades - pesquisa de campo nas seguintes localidades: Passagem Rasa (Região da Praia)

Município - Itarema/Ce.

- Período - mês de novembro de 2013.

Atividade - reuniões com o Laboratório de Cartografia Social da Universidade Federal do Ceará e visitas à Fundação Nacional de Saúde para coleta de materiais sobre os dados populacionais dos Tremembé. Município - Fortaleza/Ce.

- Período - dezembro de 2013 e janeiro de 2014.

Atividades - pesquisa de campo nas seguintes localidades: Varjota, Tapera e Batedeira I e II.

Município - Itarema/Ce.

- Período - Fevereiro de 2014.

Atividades - pesquisa de campo nas localidades da Praia de Almofala e Passagem Rasa.

Município - Itarema/Ce.

- Período - Março de 2014. 
Atividades: pesquisa de campo na localidade da Passagem Rasa e acompanhamento da audiência pública sobre empreendimentos na referida localidade.

Municípios: Itarema e Itapipoca/Ce.

\section{Etapa III}

- Período: 20 a 30 de outubro de 2014.

Atividades: desembarque em Fortaleza e preparação para a ida a campo.

Município: Itarema-Ce.

- Período: de 30 de outubro a 10 de novembro de 2014.

Atividades: pesquisa de campo na localidade da Praia de Almofala, Panã, Barro Vermelho e Mangue Alto.

Município: Itarema-Ce.

- Período: de 10 a 15 de novembro de 2014.

Atividades: preparação da palestra proferida em 13 de novembro no Núcleo de Estudos e Pesquisas em Etnicidade da Universidade Federal de Pernambuco.

Municípios: Fortaleza-Ce e Recife-Pe.

- Período: de 20 de novembro a 20 de dezembro.

Atividade: pesquisa de campo na localidade da Praia de Almofala.

Município: Itarema-Ce.

- Período: janeiro de 2015.

Atividade: pesquisa de campo nas localidades de Passagem Rasa, Varjota, Tapera e Batedeira I e II.

Município: Itarema-Ce.

- Período: fevereiro de 2015.

Atividades: pesquisa de campo nas localidades de Espraiado e Curral Velho (Acaraú) e Porto dos Barcos e Passagem Rasa (Itarema).

Município: Acaraú e Itarema - Ce

\section{Etapa IV}

- Período: de julho a novembro de 2015

Atividades: Pesquisa de campo nas localidades de Passagem Rasa, Praia de Almofala e Mangue Alto.

Município: de Itarema. 
Anexo 03

Desenhos das comunidades de Mangue Alto e Praia de Almofala

01.
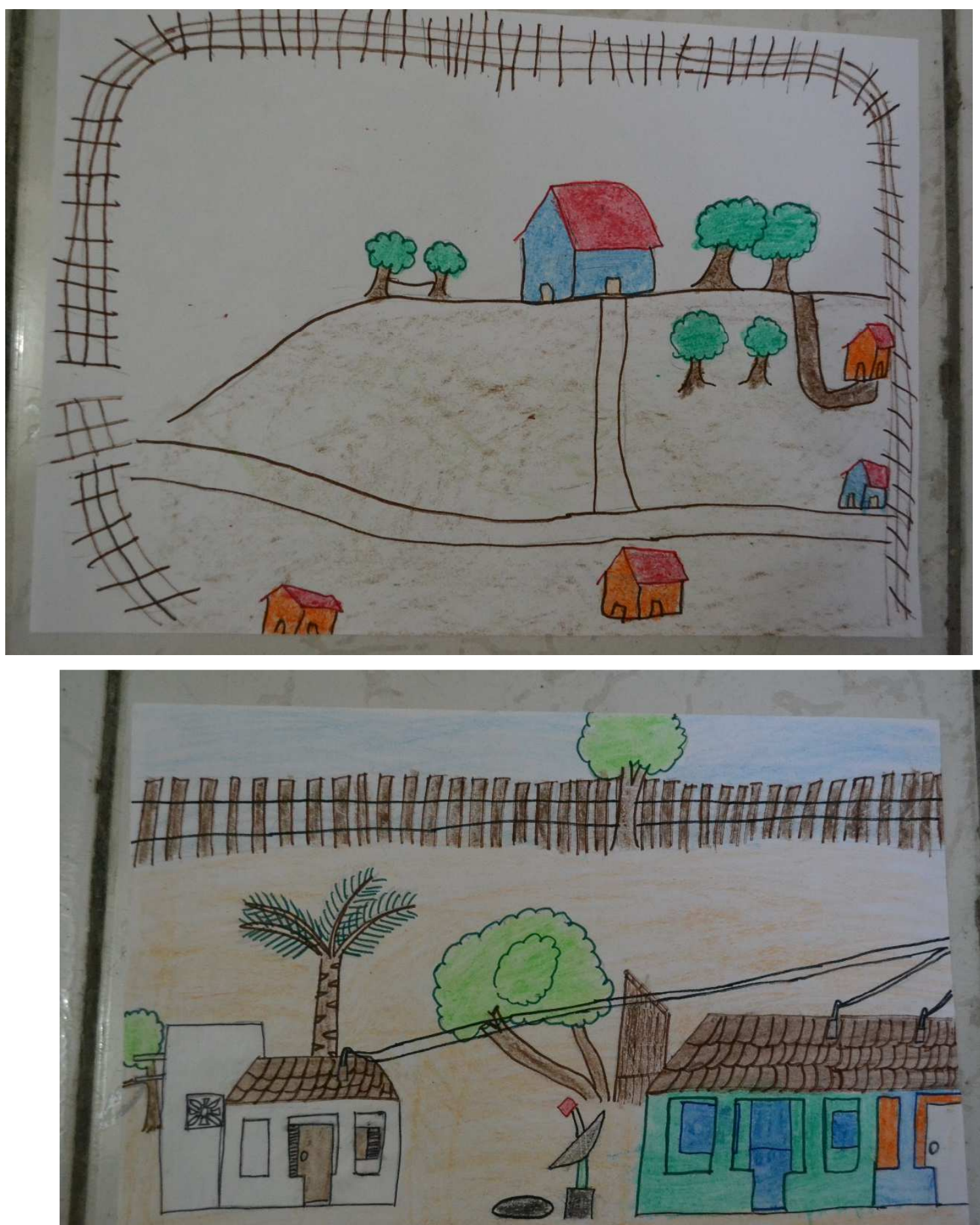

02. 
03.

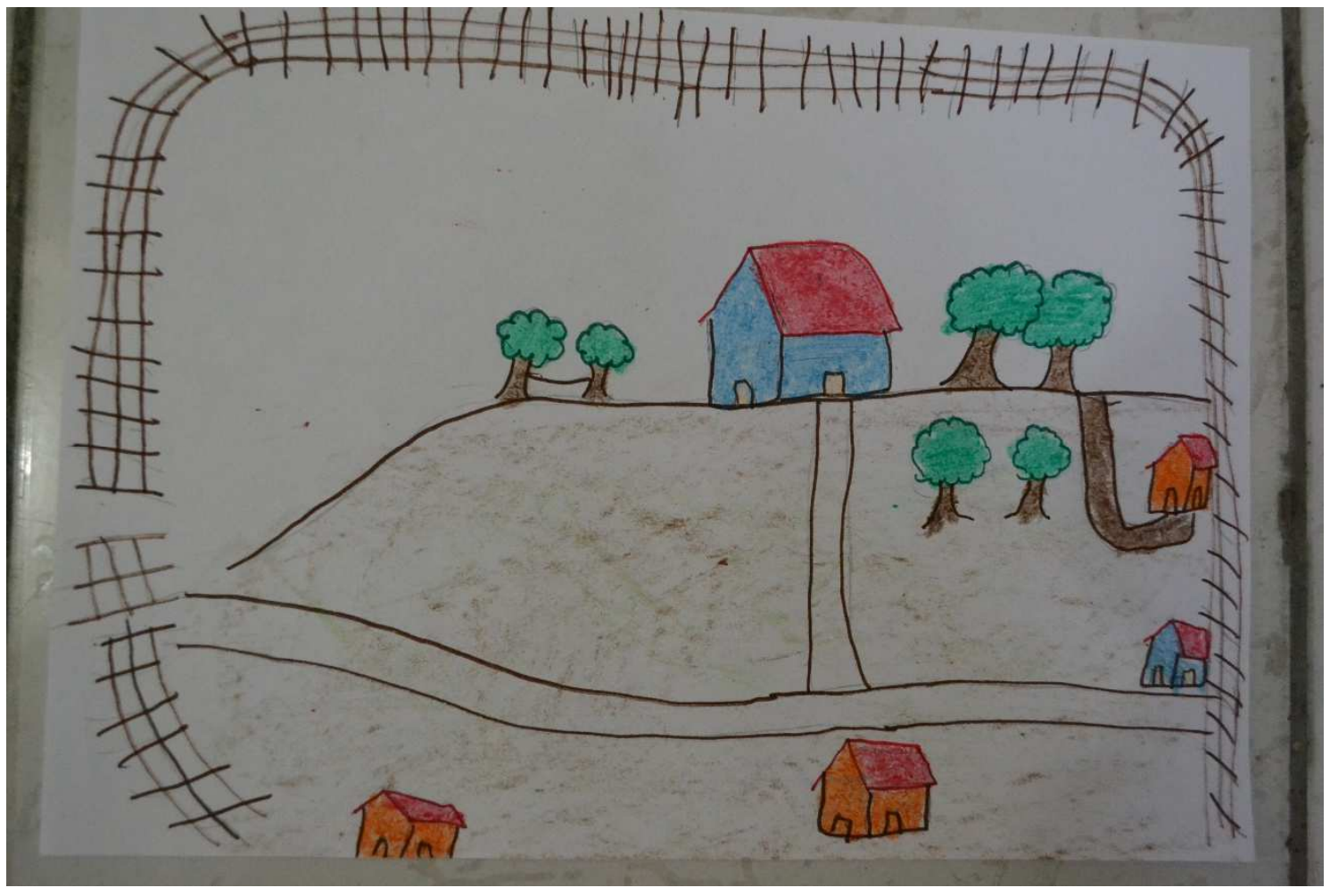

04.

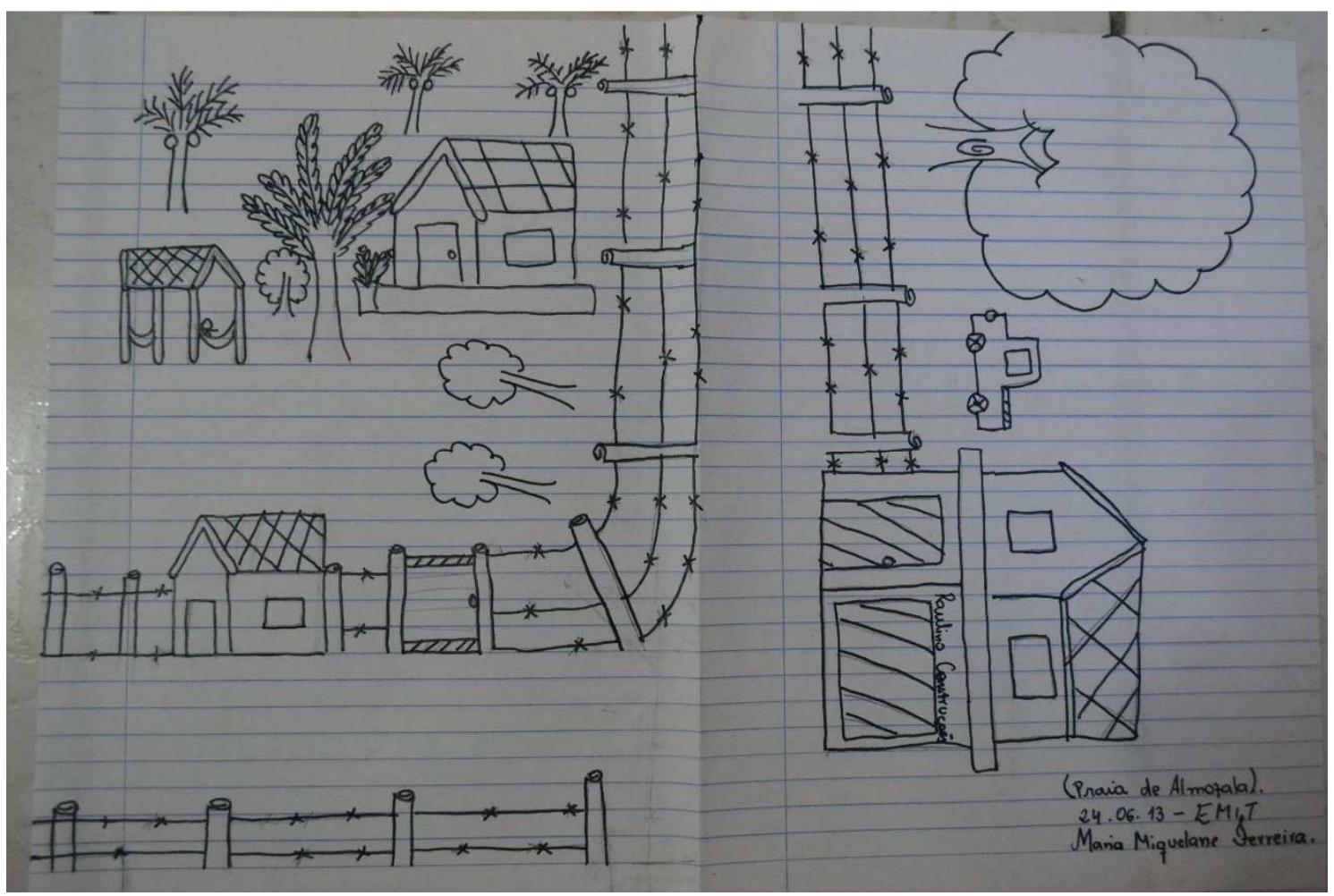


05.

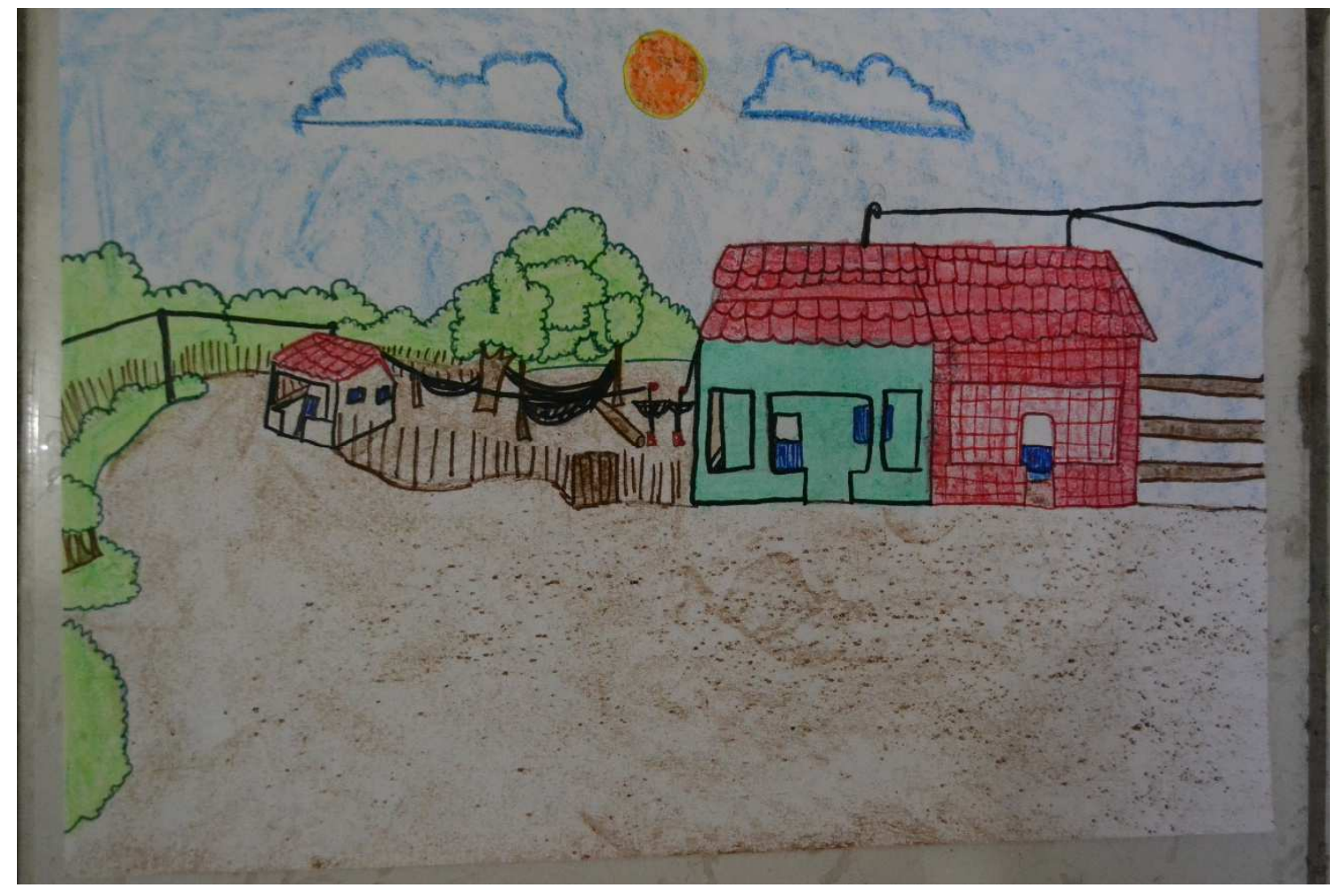

06.

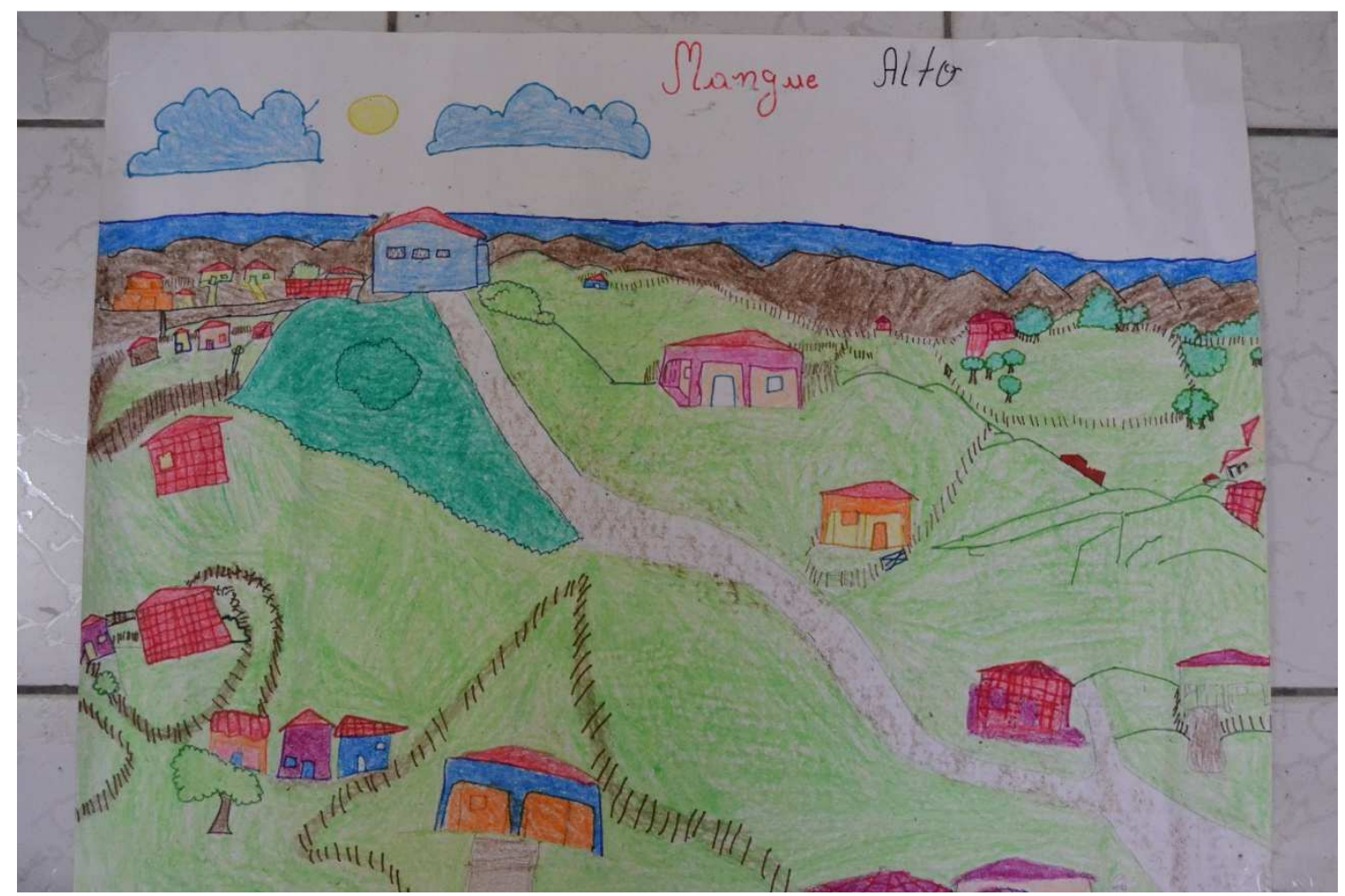

